\title{
Endotoxin and microparticles as markers for inflammation and coagulation
}

Citation for published version (APA):

Joop, K. (2009). Endotoxin and microparticles as markers for inflammation and coagulation. [Doctoral Thesis, Maastricht University]. Maastricht University. https://doi.org/10.26481/dis.20090227kj

Document status and date:

Published: 01/01/2009

DOI:

10.26481/dis.20090227kj

Document Version:

Publisher's PDF, also known as Version of record

\section{Please check the document version of this publication:}

- A submitted manuscript is the version of the article upon submission and before peer-review. There can be important differences between the submitted version and the official published version of record.

People interested in the research are advised to contact the author for the final version of the publication, or visit the DOI to the publisher's website.

- The final author version and the galley proof are versions of the publication after peer review.

- The final published version features the final layout of the paper including the volume, issue and page numbers.

Link to publication

\footnotetext{
General rights rights.

- You may freely distribute the URL identifying the publication in the public portal. please follow below link for the End User Agreement:

www.umlib.nl/taverne-license

Take down policy

If you believe that this document breaches copyright please contact us at:

repository@maastrichtuniversity.nl

providing details and we will investigate your claim.
}

Copyright and moral rights for the publications made accessible in the public portal are retained by the authors and/or other copyright owners and it is a condition of accessing publications that users recognise and abide by the legal requirements associated with these

- Users may download and print one copy of any publication from the public portal for the purpose of private study or research.

- You may not further distribute the material or use it for any profit-making activity or commercial gain

If the publication is distributed under the terms of Article $25 \mathrm{fa}$ of the Dutch Copyright Act, indicated by the "Taverne" license above, 
Endotoxin and microparticles as markers for inflammation and coagulation 
Endotoxin and microparticles as markers for inflammation and coagulation

ISBN: 978-90-6464-329-3

Lay-out: Digit@1 Xpression, Bennekom

Printed by Ponsen \& Looijen b.v.

(C) Karin Joop, 2009

All rights reserved. No part of this thesis may be reproduced, stored in a retrieval system or transmitted, in any form or by any means, without permission of the author.

Sponsors:

Rogier Polman illustrator lekenpraatje.

MSD $\propto \mathcal{P}$ Intervet

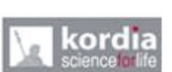




\section{Endotoxin and microparticles as markers for inflammation and coagulation}

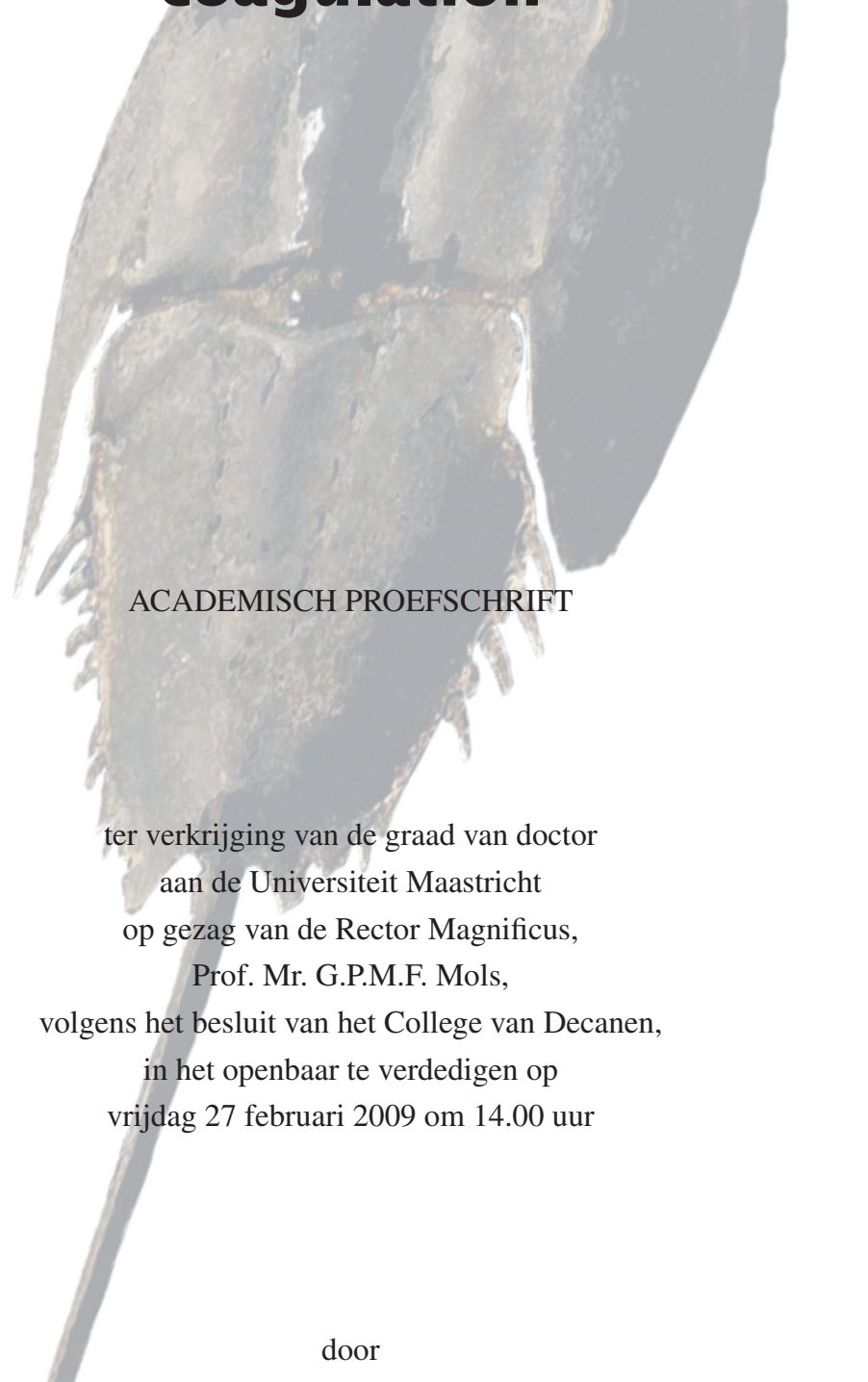

Karin Joop

geboren op 26 maar 1962 te Zaandam 
Promotor

Copromotor

Beoordelingscommissie
Prof. dr. H. ten Cate

Dr A. Leyte

Prof. dr. C. Bruggeman (voorzitter)

Em. Prof. dr. H.C. Hemker

Prof. dr. M. van Dieijen-Visser

Prof. dr. H. Zwaveling

Prof. dr. J. van Dissel, infectioloog LUMC (Leids Universitair

Medisch Centrum) 
'I beseech you to take interest in these sacred domains so expressively called laboratories. Ask that there be more and that they be adorned for these are the temples of the future, wealth and well-being. It is here that humanity will grow, strengthen and improve. Here, humanity will learn to read progress and individual harmony in the works of nature, while humanity's own works are all too often those of barbarism, fanaticism and destruction.' -- Louis Pasteur 



\section{Contents}

Chapter I General introduction 9

Chapter II Relationship between intra-uterine bacterial contamination, endotoxin levels and the development of endometritis in postpartum cows with dystocia or retained placenta

M.J.W. Dohmen, K. Joop, A. Sturk, P.E.J. Bols, J.A.C.M. Lohuis

Theriogenology, 2000; 54:7: 1019-1032

Chapter III Relationship between gastro-intestinal complaints and endotoxemia,

cytokine release and the acute-phase reaction during and after a long-distance triathlon in highly trained men

A.E. Jeukendrup, K. Joop, A. Sturk, J.H.J.C. Stegen, J. Senden, W.

H.M. Saris, A.J.M. Wagenmakers

Clinical Science, 2000; 98:47-55

Chapter IV Plasma procalcitonin before and after ultra endurance exercise

K. Joop, A.E. Jeukendrup,A.J.M. Wagenmakers, R. Nieuwland, A.Sturk In preparation

Chapter V Predictive values for fatal outcome in septic patients: A comparison between the SIMPLY RED ${ }^{\circledR}$ - and the chromogenic LPS-assays K. Joop, J. Berkhout, P.H.P. Groeneveld, R. Nieuwland, A. Sturk

Chapter VI Endotoxin, cytokines and procalcitonin in febrile patients admitted to hospital: identification of subjects with high mortality risk

$K$. Joop, P. van Langevelde, J. van Loon, M. Frölich, P.H.P. Groeneveld, R.G.J. Westendorp, J.T. van Dissel

Clinical Infection Diseases, 2000; 31:1343-1348

Chapter VII Microparticles from patients with Multiple Organ Dysfunction Syndrome and Sepsis support coagulation through muliple mechanisms K. Joop, R. Berckmans, R. Nieuwland, J. Berkhout, F.P. Romijn, C.E. Hack, A. Sturk

Thrombosis and Haemostasis, 2001; 85:810-820 
Chapter VIII Decrease number of platelet derived microparticles in severe dengue virus infections with haemorrhagic tendency

K. Joop, A.T.A. Mairuhu, T.E. Setiati, P. Koraka, A. Soemantri,

A.D.M.E Osterhaus, D.P.M. Brandjes, A. Sturk, R. Nieuwland,

H. ten Cate, A. Leyte, E.C.M. van Gorp

Submitted for publication

Chapter IX Pravastatin reduces levels of the glycoprotein IIIa subunit from the

fibrinogen receptor on platelet-derived microparticles in patients with type 2 diabetes

D.W. Sommeijer, K. Joop, A. Leyte, P.H. Reitsma, H. ten Cate

Thrombosis and Haemostasis, 2005; 3:1-4

Chapter X General Discussion

Summary

Samenvatting

Dankwoord

Curriculum Vitae 


\section{CHAPTER}

\section{General introduction}

\section{Contents of the introduction}

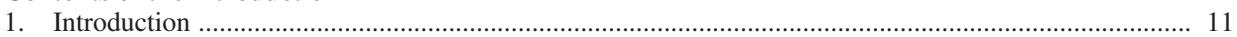

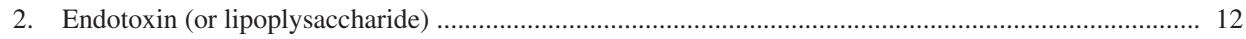

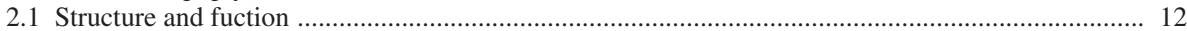

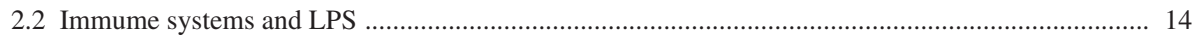

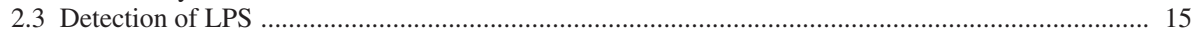

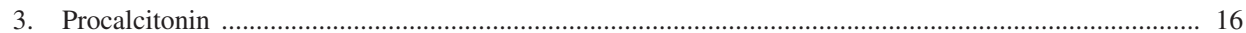

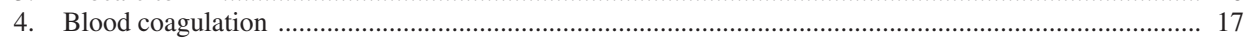

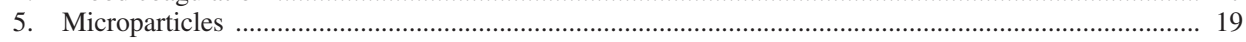

6. Endotoxin and microparticles as players in inflammation and coagulation ..................................... 20

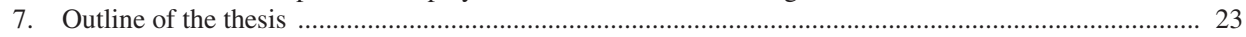

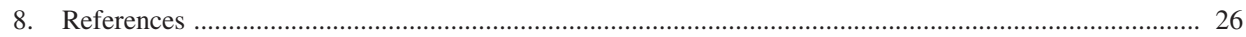





\section{Introduction}

Sepsis is a major complication of bacterial infections, and is associated with a systemic inflammatory response syndrome (SIRS) involving activation and apoptosis of cells and activation of the blood coagulation system up to the level of disseminated intravascular coagulation (DIC). The mortality rate from sepsis is still high. In an update on the epidemiology of sepsis, several studies are cited that report mortality rates of $20-52 \%{ }^{1}$. In more recent intervention trials the mortality from sepsis remains high at around 30-50\% and apparently, in spite of advances in diagnostic procedures, critical care facilities and antibiotic regimens, sepsis remains a very complex and severe syndrome $e^{2-9}$.

One aspect related to the high mortality is the (lack of) timely and accurate assessment of high and low risks stages in the individual patient. This relates to the criteria used to classify the different stages of sepsis. In the 1991 American Consensus Conference the entities sepsis, severe sepsis and septic shock were outlined as progressive phases of sepsis associated with increased organ failure and mortality (discussed $\mathrm{in}^{10}$ ). Nowadays, this staging remains clinically useful. Because of a lack of sensitivity and specificity it was proposed to change the term SIRS in PIRO (predisposing factors, infection, response, organ dysfunction) as a better method for staging the continuum of the syndrome of sepsis ${ }^{10}$. However, so far SIRS remains the preferred terminology. In addition to clinical criteria laboratory markers are being used to estimate the stage of sepsis and its prognosis, but there are hardly any specific indices available: altered white blood cell count, thrombocytopenia or other markers of DIC, elevated C reactive protein, increased procalcitonin, hyperglycemia, lactic acidosis, or unexplained alterations in liver or kidney function tests are all examples of clinically used but hardly specific assays. Although combinations of some of these tests may help to estimate the risk of the individual patient and to assist in decision making on therapy, more specific laboratory tools are still missing in clinical practice.

The existing problems with staging of patients according to degree of illness and prognosis may in part explain the many negative (lack of clinical benefit) clinical trials with new therapeutic agents, such as experimental immunotherapy and treatment with the synthetic Lipid A analog in patients with sepsis, in spite of promising preclinical data ${ }^{11-16}$. Inclusion of very heterogeneous patients without further stratification may have contributed to dilution of potentially relevant effects of the tested drugs. Another, related factor in the failure of anti-inflammatory agents may be insufficient knowledge of the pathophysiology of sepsis and its sequelae such as DIC, making it difficult to decide on the appropriate timing of experimental medication. With regard to the latter, it appears to be particularly difficult to establish at which stage inflammation is still beneficial, in other words at which moment in time is intervention in inflammation beneficial and when does it become detrimental ${ }^{17,18}$ ? These problems have also been encountered in recent studies with anticoagulant agents in patients with sepsis. In these studies, which have yielded 
negative (antithrombin, tissue factor (TF) pathway inhibitor) or positive (activated protein $\mathrm{C}$, APC, but in follow up studies equivocal) outcomes, there is evidence that the timing of the investigative drug is a critical determinant. Hence, administration of both antithrombin and APC is probably only beneficial in those patients with most severe sepsis while potentially detrimental in patients with less severe sepsis ${ }^{18-21}$.

The above mentioned considerations about prognosis and staging of sepsis have also played a role in the development of assays for measuring endotoxin levels in patients with sepsis. Since infections with gram negative bacteria are linked to severe sepsis with high mortality and their confirmation by culture is time consuming many investigators have tried to set up laboratory assays for detecting the main pathogenic component of these bacteria, the membrane lipopolysaccharide, LPS. Utilizing sensitive assays for endotoxin in conjunction with other laboratory markers might be one way by which timely diagnosis of gram negative infections becomes feasible.

A related subject is the laboratory determination of specific markers of disease. Since severe sepsis is associated with DIC in at least $50 \%$ of the cases ${ }^{22}$, activation of cells in conjunction with activation of coagulation has become a target of investigation. During infection, cells that are stimulated or undergo apoptosis release vesicular bodies from the plasma membrane, which are called microparticles (MP), also referred to as microvesicles ${ }^{23}$. After having been considered inert cell debris for a long time, MP are now thought to play a role in the pathophysiology of inflammatory disorders by presenting specific antigens and by interacting with neighboring or remote cells. These MP supply phospholipids and may enhance both inflammation and coagulation, constituting an important link between these processes ${ }^{24}$. From a diagnostic point of view determination of MP in a blood sample combines the advantages of a quantitative assessment (numbers of particles) with qualitative observations (antigens presented at the membrane of particles). In addition, the resuspension of MP in plasma allows for quantitative determination of the effects on activation of coagulation (thrombin generation).

In the following paragraphs we present in greater detail two topics related to the diagnosis and pathophysiology of sepsis and other inflammatory disorders. First, the importance of LPS as an agonist of SIRS in sepsis and the detection of LPS in blood. Second, the role of MP as a cell derived source of pro-inflammatory and pro-coagulant activity that trigger and amplify SIRS and DIC in sepsis.

\section{Endotoxin (or lipopolysaccharides, LPS)}

\subsection{Structure and function}

The terminology 'endotoxins' was first used towards the end of the 19th century, to distinguish these molecules from 'exotoxins', which are actively secreted into the environment by gramnegative bacteria, gram-positive bacteria, as well as a variety of other pathogens ${ }^{25}$. Endotoxins

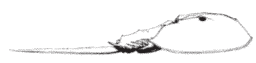


are integral components of the outer membrane of gram-negative bacteria. They have not been found in gram-positive cell walls, mycobacterial cell walls, or fungal cell walls. Endotoxins (also termed lipopolysaccharides (LPS)) are composed of protein, lipid and polysaccharide.

Immunochemically, LPS consists of three parts (figure 1); lipid A, a polysaccharide component with an inner and outer core, and the highly variable O-antigen portion composed of oligosaccharide subunits ${ }^{26-28}$. The inner core sugars are added to Lipid A, followed by addition of oligosaccharide subunits to the outer core to form the $\mathrm{O}$ side chain. Bacterial mutants that lack the inner core or the O-specific chain produce 'rough LPS' and wild-type strains produce 'smooth LPS', because of the morphology of the colonies when cultured on medium. Lipid $\mathrm{A}$, the minimal structure of LPS, consists of a variable number of $\mathrm{C}_{12-14}$ fatty acids linked to a phosphorylated $\mathrm{N}$-acetylglucosamine dimer ${ }^{29}$. The lipid A variants from most gram negative bacteria that exist, as human commensals, pathogens or colonizers, are very similar with regard to the indicated structure, also referred to as 'mucosal' lipid $\mathrm{A}^{28}$. The composition, number and acyl side chain are important in immunogenic activity, in combination with different Lipid A conformations. The lipid A structures vary considerably in potency. The biological activity is associated with the lipid component (Lipid A) and immunogenicity (innate immunity) is associated with the polysaccharide components. The structural and conformational parameters, endowing lipid A with its potent bioactivity, have been well characterized. The toxic effects of endotoxins are initiated by the specific interaction of lipid A with LPS receptors on macrophages/monocytes resulting in the production of cytokines like tumor necrosis factor. The lipid A regions involved in specific binding and cell activation have been characterized. The interaction and subsequent mediator production can be specifically and inhibited by lipid A antagonists. The composition of LPS varies between different species of bacteria, and some bacteria modulate the structure of LPS such that they evade the innate immune system response of their host and to maintain the integrity of the outer membrane.

\section{Gram negative bacteria; Cell wall}

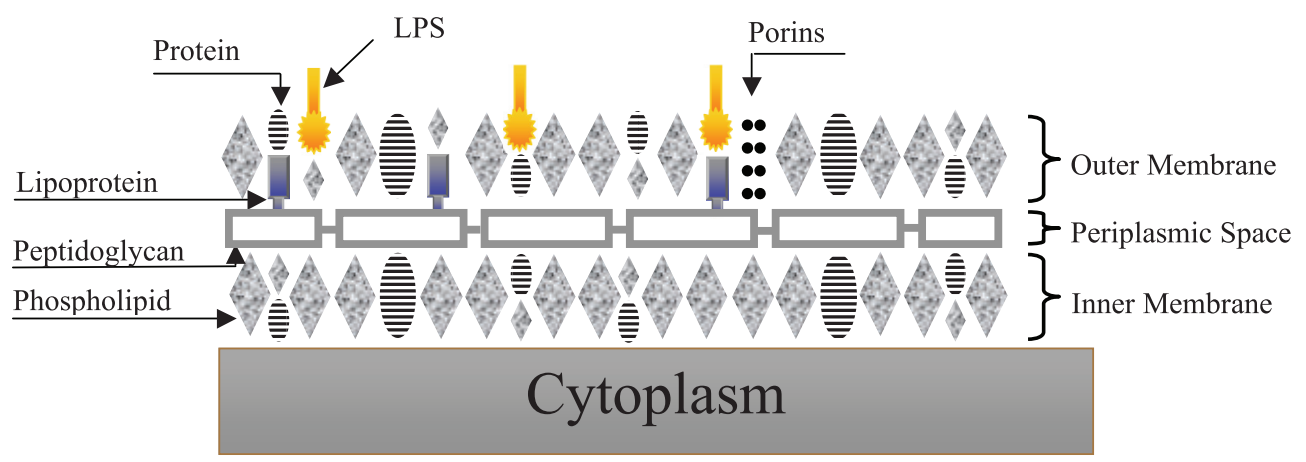

Figure 1. A schematic diagram of the cell wall from gram negative bacteria. For most purposes the terms endotoxin, lipopolysaccharide or LPS are synonymous. 
Compounds that bind LPS may promote inhibition or neutralization and subsequent interruption of the host inflammatory response ${ }^{30}$. High-, low-, and very low-density lipoprotein bind endotoxin, which may reduce endotoxins toxicity by enhanced clearance of the lipoproteinendotoxin complex from the circulation ${ }^{31}$. Bactericidal-permeability/increasing (BPI) protein is derived from the azurophilic granules of neutrophils and neutralizes endotoxin after binding with high affinity ${ }^{32,33}$. This binding of endotoxins to BPI results in increased permeability of a variety of gram negative bacteria that already have been phagocytosed ${ }^{34}$. LPS/binding protein (LBP) is structurally related to BPI protein, but does not have bactericidal activity. LBP binds to lipid A and acts as an opsonin, enhancing the phagocytosis of gram negative bacteria ${ }^{34,35}$.

Extrapolation of data from experimental animal models of infection or endotoxemia to humans is complicated by the fact that species differences exist with respect to sensitivity for endotoxin, for example the concentration of endotoxin needed to produce an immunologic effect (Table 1) in a rat is 25,000 times greater proportionally than what is required to produce the same immunologic effects (Table 1) in humans. In humans the sensitivity to endotoxins is primarily dependent on the balance of pro- and anti-inflammatory cytokines, where an anti-inflammatory cytokine profile of a high ratio of IL-10 to TNF-alpha is associated with fatal outcome in patients with meningococcal infection $^{36,37}$. This suggests that a strong host response to endotoxin may be important in the eradication of bacterial infection, which may have been a contributing factor to the many negative or untoward outcomes in clinical trials with anti-inflammatory drugs ${ }^{38,39}$.

\subsection{Immune system and LPS}

The innate immune system has several mechanisms to recognize microbial pathogens; a) the complement system, which has specialized receptors that enable nature killer (NK) cells to sense non-self, missing-self and induced-self, b) the Toll-like receptors (TLRs) as sensors of discrimination

Table 1. Endotoxin (LPS) induce

a) Fever-leukocytes take up Lipid A which induces the synthesis and secretion of IL-1, which acts on the heat regulation centres in the brain to cause fever

b) Shwartzman reaction - hemorrhagic necrosis at the site of infection following exposure of another part of the body to a relatively small amount of Lipid A. This is due to the clearing of fibrin polymers at the inflammation site

c) Disseminated intravascular coagulation (DIC) - characterized by microvascular fibrin formation, thrombosis and organ dysfunction, as well as life threatening bleeding due to consumption of clotting factors and cells

d) Macrophage production of tumor necrosis factor alpha (TNF-alpha) which results in various effects

e) Activation of complement via the alternative pathway whereby the activator surface (Lipid A) of the Gram-negative cell facilitates the combination of Factor B and C3b

f) Stimulation of bone marrow cell proliferation

g) Non-specific enhancement of immune responses (i.e., action as adjuvants)

h) Enhancement of radiation resistance

i) Clotting of horseshoe crab amoebocyte lysates (Limulus lysate reaction)

j) Engender hypersensitivity reactions 
between self and non-self, a key requirement of any immune system ${ }^{40}$. The receptor that recognizes LPS and other microbial molecules was shown to be dependent on the integrity of a single locus known as Lps ${ }^{41}$. In 1998 the Lps locus was identified as the TLR4 locus. There are 13 mammalian TLRs identified, most are known to recognize specific conserved microbial molecules such as Lipid A that activates TLR4. The initial uptake and phagocytosis of microbes by antigen presenting cells is facilitated by receptor mediated recognition of microbial molecules. It has been suggested that TLR4 acts to concentrate LPS thereby increasing sensitivity of the receptor complex to its ligand.

Both the scavenger receptors (eg macrophages express several different types of scavenger receptors that bind and internalise modified lipoproteins, such as those contributing to foam cell formation in atherosclerosis) and receptors of the complement system are important in this process $^{40}$. As one of the monocyte/macrophage receptors CD14 appears to play an important role in relation to the complex of TLR4 and MD2 (myeloid differentiation-2=lymphocyte antigen 96 (LY96) $)^{42}$. When monocytes/macrophages are activated they release various defense regulatory cytokines, including interleukin (IL)-1, IL-6, IL-8, tumor necrosis factor alpha and platelet activating factor. These cytokines bind to cytokine receptors on target cells and initiate inflammation and activate both the complement and coagulation pathways. These inflammatory responses have been employed as a model in which LPS is administered to humans or primates to dissect procoagulant and anti-fibrinolytic pathways, as discussed further on ${ }^{43}$.

\subsection{Detection of LPS}

Rabbits are similarly susceptible to LPS as humans and this observation has been applied to test solutions suspected from LPS contamination in rabbits. Should the rabbit develop a fever after inoculation of a test compound, the presence of LPS is likely. Aside from the costs and ethical concerns with the use of rabbits for this purpose, this method has other limitations such as the long incubation time of up to 48 hours to produce a definitive result.

Bang was studying the circulation of blood using horseshoe crabs when he found that one of his crabs died as a result of a Vibrio vulnificus bacterial infection ${ }^{44,45}$. The infection caused a condition in which almost the entire blood volume of the crab clotted into a semi-solid mass. Other bacterial strains had not produced this sort of reaction. Bang found that not only live

Figure 2. A horseshoe crab; Limulus Polyphemus.

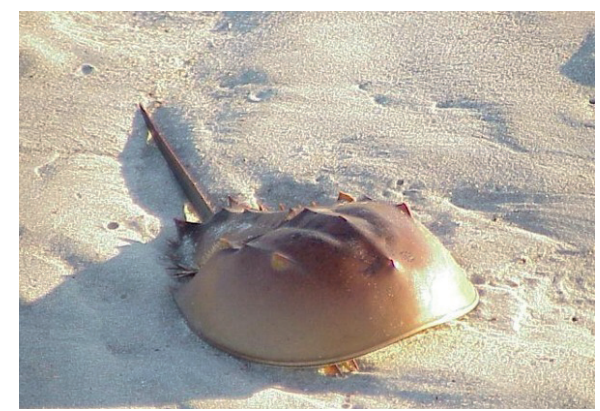


gram negative bacteria produced this reaction, but also heat-killed bacteria, suggesting that not bacterial activity but rather a bacteria-derived substance was involved ${ }^{46,47}$. In collaboration with Jack Levin, Bang further established the principles of endotoxin induced immune triggering in the horseshoe crab or Limulus Polyphemus, a member of the family of arthropods and a common inhabitant of the Atlantic coast. With abundant bacteria in the external milieu, the horseshoe crab has developed sensitive means for detecting LPS shed by bacteria in its environment ${ }^{46,47}$. Limulus is a cold-blooded animal, without the ability to develop fever or other pro-inflammatory networks. Its innate defence mechanism is comprised of a single type of blood cell, the amoebocyte, a cell with a number of physiological functions, including phagocytosis and clearance of bacteria and dead cells and repair of wound sites ${ }^{47}$. The cells contain small granules that release coagulation proteins called coagulogens upon activation by bacterial endotoxin. The clots formed are thought to limit the bacterial invasion and to provide a barrier to the outside environment in the case of a severed limb or large incision. This system is comparable to the vertebrate blood coagulation system that serves to protect against bleeding from trauma and probably also to support innate immunity in vertebrates, where the coagulation machinery is triggered by LPS and may also limit bacterial invasion.

The principle of the Limulus amoebocyte reaction to LPS has been extensively explored and utilized in the form of a diagnostic assay ${ }^{48,49}$. In the Limulus Amoebocyte Lysate (LAL) assay plasma or other fluid sample is mixed with reconstituted LAL and allowed to clot in a test tube. After 45 minutes the tube is inverted and if a clot has formed it will stick to the top of the inverted tube; the test is positive ${ }^{48,49}$. The LAL assay received FDA approval in the 1970's for use in the testing of drugs, blood products, intravenous fluids, and disposable pharmaceutical devices and in 1983 was registered in the U.S. Pharmacopoeia ${ }^{50-53}$.

Extracting blood from the crab produces the lysate. This is done using a non-lethal method where blood is taken from a large dorsal blood sinus, the pericardium ${ }^{54}$. The blood can be centrifuged to obtain a pellet of amoebocytes that is resuspended with saline. This causes the cells to lyse- and to release the coagulogen into solution. The resultant solution is filtered to remove cellular debris and then freeze-dried to form a white powder of lysate ${ }^{55,56}$.

\section{Procalcitonin}

Although the endotoxin proven to be useful for screening of solutions for LPS contamination, it has never become a suitable test to detect gram negative bacteremia in patients for various reasons including poor sensitivity. In human disease there are no reliable parameters differentiating acute bacterial infection from other types of inflammation. Hence, non specific signs like elevated body temperature, or non specific lab tests such as white cell count, erythrocyte sedimentation rate or C-reactive protein levels are applied to detect inflammation, while blood cultures need to be awaited to confirm a diagnosis of (gram negative) sepsis. Of the

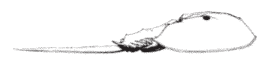


investigated laboratory biomarkers procalcitonin (PCT) appeared to be a diagnostic parameter that is selectively induced during bacterial infection ${ }^{7}$. PCT is not or only slightly induced by viral infections, autoimmune disorders, neoplastic disease or by (surgical) trauma. In contrast, PCT promised to distinguish a bacterial from a non-bacterial inflammation, as well as to perform as a monitoring parameter in critically ill patients ${ }^{58-60}$. PCT is a 116 amino acid protein with a molecular weight of $13 \mathrm{kDalton}$. In healthy individuals active calcitonin is produced and secreted by C-cells of the thyroid gland after specific intracellular proteolytic processing of the prohormone. The plasma concentration of PCT in healthy individuals is very low, in the nanogram per millilitre range. PCT is a very stable protein in vivo with a half-life time of about 25-30 hours. In patients with severe infection or sepsis, plasma concentrations of PCT range from 1 tot $>1000 \mathrm{ng} / \mathrm{ml}^{61}$. During bacterial infection PCT is probably not primarily produced by $\mathrm{C}$-cells of the thyroid, but may originate from neuroendocrine cells of lung or intestine.

In healthy volunteers PCT induction was stimulated by i.v. injection of bacterial endotoxin $(4 \mathrm{ng} / \mathrm{kg} \text { body weight })^{58}$ and detected in plasma 2 hours after injection, rapidly rising within 6 to 8 hours and reaching a plateau after approximately 12 hours. Within 2 to 3 days PCT concentrations had again assumed basal values ${ }^{58}$.

The increase in PCT levels after i.v. injection of endotoxin follows the surge in TNF-alpha and IL-6 in blood, which gain peak levels around 90 and 180 minutes respectively. PCT values start to increase at 3 to 6 hours after injection reaching a summit at 6 to 8 hours. In contrast to the early rise in PCT, C-reactive protein levels were still not increased 6 hours after injection, showing that this acute phase protein is a rather slow marker as compared to PCT ${ }^{66,67}$. Clinically, PCT levels remain increased during ongoing infection ${ }^{59}$ and appear to correlate with the clinical course ${ }^{62-65}$.

\section{Blood coagulation}

The principle of the cascade or waterfall mechanism of the coagulation process was described in detail in $1964^{68,69}$. In this model, that is still valid today, coagulation was indicated to be an ordered sequence of amplifying reactions ${ }^{70}$. It encompasses two separate pathways that converge at the level of factor $\mathrm{X}$ activation. The extrinsic pathway starts with the interaction of phospholipid-bound tissue factor (TF) and factor VII to activate factor X. Activated factor X is also generated by the intrinsic pathway, which is initiated by activation of factor XII when it comes in contact with a negatively charged surface. The extrinsic system was assumed to be the primitive pathway because fewer factors were involved and because birds and reptiles possess only this system. In contrast, the intrinsic system was considered more complex and present only in 'higher' life forms.

Clinical findings raise confusion regarding the intrinsic route of coagulation as an important pathway. While deficiencies in factors VIII and IX, underlying the haemophilias A and B, clearly are highly relevant bleeding disorders, a severe deficiency in factor XI is only associated with 


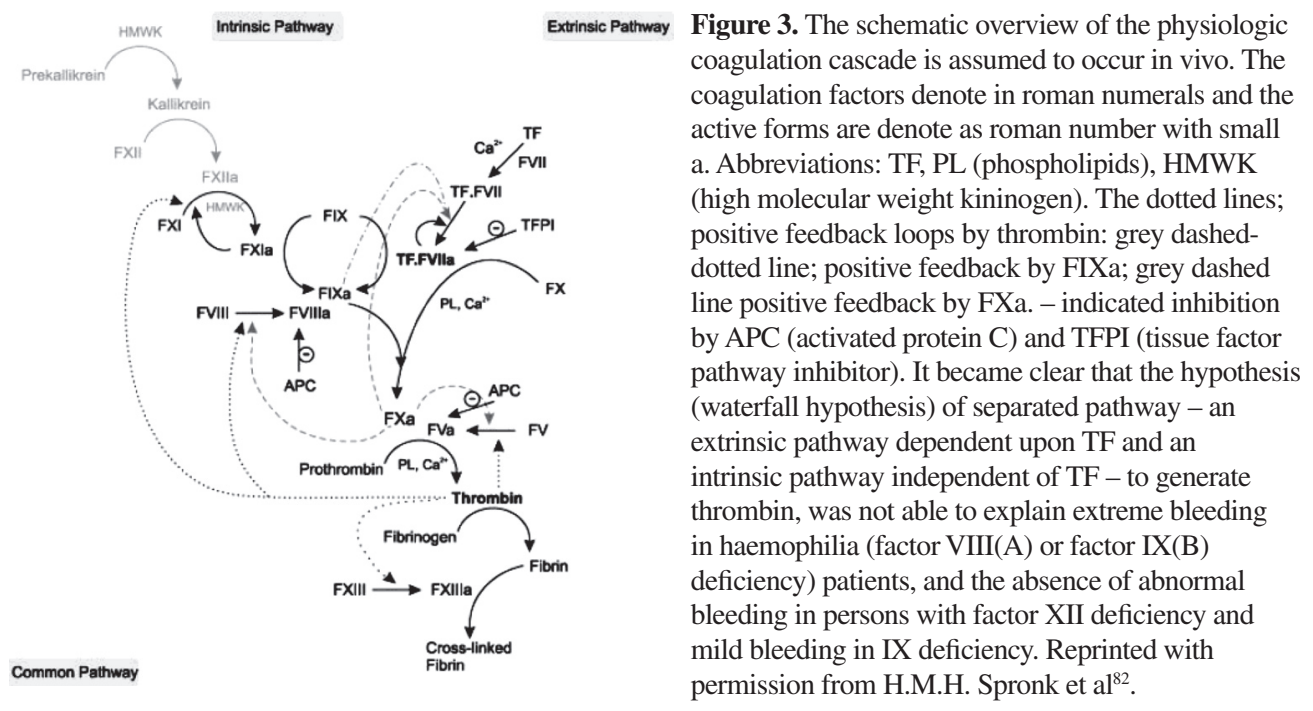

abnormal bleeding at older age or upon major tissue trauma. More importantly, a major defect in the 'contact' protein factor XII is not associated with bleeding at all, rather with increased risk of thrombosis ${ }^{71-75}$. One possible explanation for these discrepancies is the existence of reactions that bypassed factors XII and XI in the activation of factor IX, a route that was indeed first demonstrated by Josso ${ }^{76}$.

Based on these new experimental findings the earlier concept of separate intrinsic and extrinsic clotting systems became obsolete. Rather, one central TF driven cascade is postulated to form the basis of blood coagulation ${ }^{77,78}$. Thrombin plays a critical regulatory role with the potential to display an anticoagulant action under physiological conditions (thrombomodulin mediated protein $\mathrm{C}$ activation) and an uncontrolled procoagulant activity under pathophysiological conditions (through activating factors XI, V, VIII, fibrinogen and XIII). In addition, thrombin may impair fibrinolysis by activating TAFI (thrombin-activated fibrinolysis inhibitor) ${ }^{79,80}$. The long-standing concept that the FXII-induced intrinsic coagulation pathway is not important for clotting in vivo was recently challenged. Recent studies indicate that arterial thrombus formation is impaired in mice with a complete deficiency in factor XII ${ }^{81}$. Infusion of human FXII into FXII-null mice restored injury-induced thrombus formation ${ }^{82}$. Hence, factor XII appears to contribute a procoagulant role, probably confined to situations of (arterial) thrombosis, rather than in physiological regulation of hemostasis, such as ischemic stroke ${ }^{83}$ but its specific role needs further characterization. A summary of a model of coagulation in indicated in figure $3^{82}$.

\section{Inhibitors of blood coagulation}

First, antithrombin was discovered in 1965 as a major coagulation inhibitor, deficiency of which was associated with an increased risk of venous thrombosis ${ }^{83}$. Antithrombin binds most coagulation enzymes (serine proteases) in a glycosaminoglycan catalyzed 1:1 complex, which is 
cleared from the blood. Second, the proteins $\mathrm{C}$ and S system was identified ${ }^{84}$. This anticoagulant system is established by the thrombin dependent activation of protein $\mathrm{C}$ upon interacting with the endothelial cell receptor thrombomodulin (TM). Activated protein $\mathrm{C}$ interacts with endothelial protein $\mathrm{C}$ receptor (EPCR) to induce cell signalling pathways and inactivates in concert with the cofactor protein $\mathrm{S}$ the activated factors Va and VIIIa. The consequence in plasma is a down regulation of the rate of thrombin generation, i.e. a net anticoagulant action. Third, the TF pathway inhibitor (TFPI) mechanism was most recently identified. TFPI comprises several pools of molecules that inhibit the factor VIIa/TF pathway, requiring the presence of factor $\mathrm{Xa}$, in a quaternary complex at the cell surface ${ }^{85}$.

Interplay between coagulation activation and - inhibition is now established as a cell surface dependent processes ${ }^{82}$. Blood coagulation is regarded as an integrated mechanism comprising three overlapping phases with plasma protease inhibitors modulating the procoagulant response at all stages as well as localizing reactions to cell surfaces by inhibiting active proteases that diffuse into the fluid phase. These three phases are initiation ${ }^{86}$, which occurs on TF-bearing cells and results in formation of factor Xa, factor IXa and thrombin; amplification of the coagulant response, which occurs as the process moves from the TF-bearing cell to the activated platelet surface, where activated cofactors are accumulated; and propagation in which the active proteases assemble with their cofactors on the platelet surface - and a burst of thrombin generation resulting in fibrin polymerization occurs.

One of the essential features of these reactions is the generation of thrombin at a phospholipid surface. TF initiates coagulation activity generating small amounts of thrombin that act on cells as well as on cofactors. Together activated platelets and cell fragments comprise a catalytic surface on which factor $\mathrm{X}$ and prothrombin are being converted into enzymes; these enzymatic machineries being referred to as the tenase and prothrombinase complexes. Held in charge by protease inhibitors, mainly antithrombin and activated protein $\mathrm{C}$, under physiological conditions, the amount of thrombin is just sufficient to maintain a basal level of protein $\mathrm{C}$ activation. In this physiological milieu the amount of activated cells is probably low. Hypothetically, upon amplification of thrombin generation, more cells become activated to shed membrane particles, referred to as microparticles (MP), which participate in the process of coagulation activation. These MP may play a distinct and prominent role in linking cell activation and apoptosis to inflammation and coagulation.

\section{Microparticles}

Microparticles are small membrane vesicles (particles) that are released from cells upon activation or during apoptosis. The release of MP is thought to be an integral part of the membraneremodelling process in which the asymmetric distribution of phospholipids between two leaflets is lost. In body fluids cellular MP constitute a heterogeneous population, differing in cellular origin, numbers, size, antigenic composition and functional properties ${ }^{24,87,88}$. After having long been 
considered 'cell dust', MP have more recently been postulated to reflect a balance between cell stimulation, proliferation and death and it is conceivable that MP play a role in the maintenance of homeostasis in multicellular organisms ${ }^{89,90}$. This may be an explanation for the observation of MP in blood from healthy individuals ${ }^{90}$. However, MP have also been identified as vectors in transcellular exchange of biological information ${ }^{88,91-93}$. The majority of these MP are from platelets ${ }^{90}$. MPs from activated cells can elicit an adverse response from other cells, themselves undergoing membrane vesiculation, leading to pathogenic amplification, (as summarized in table 2) ${ }^{92}$.

The presence of MP has been known for a long time. Already in the 1940s it was seen that human plasma and serum contained a subcellular element that enhanced fibrin formation ${ }^{88,89}$. Chargaff was one of the pioneers who identified the involvement of certain phospholipid substances in blood coagulation $^{88}$. The observation that such phospholipids accelerated the rate of clotting and the importance of electrostatic interactions between lipidic anions and cationic groups in proteins led to the isolation of cellular macromolecular particles. The study of MP was facilitated by the development of the electron microscopy program by Noggle in the 1960s, which facilitated the identification of a subcellular factor consisting of small vesicles ('microparticles') ${ }^{94,95}$.

Nevertheless, it is still not clear whether cell activation and apoptosis lead to the formation of similar MP, in terms of size, lipid and protein position and (patho-) physiological effects ${ }^{96}$.

\section{Endotoxin and microparticles as players in inflammation and coagulation}

Circulating LPS triggers an array of inflammatory reactions. These involve the release of proinflammatory cytokines, activation of the coagulation system, fibrinolysis (and subsequent inhibition of fibrinolysis), activation of complement, as well as activation of different cells including neutrophils and monocytes associated with MP formation ${ }^{97}$. Production of TNF-alpha and IL-1 (as part of inflammatory reactions) are both responsible for the loss of normal anticoagulant activity of endothelial cells, by cleavage as well as down regulation of thrombomodulin and endothelial protein $\mathrm{C}$ receptor (EPCR); the result is a procoagulant endothelial surface ${ }^{97-98,110,116}$. The influence of natural anticoagulants in inflammation depends on the strength of the inflammatory stimulus. Whereas in low LPS concentrations in human models, the influence of (administered) TFPI and antithrombin

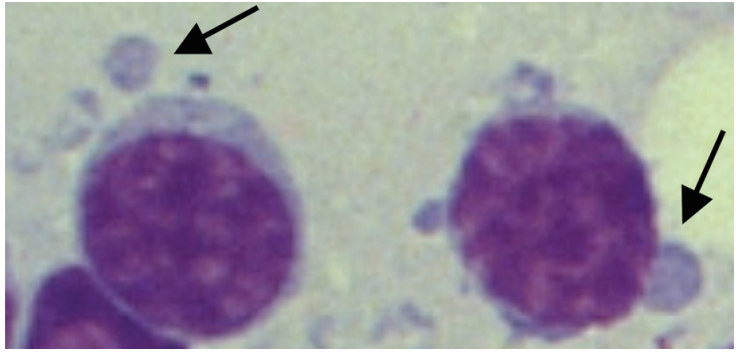

Figure 4: Light-microscope (50x10) view of a lymphnode which shows lymphocytes shedding microparticles in haematological malignancy (stained with May-Grunwalds/ Giemsa) 
on coagulation is very limited, the importance emerges at septic conditions in primates where TFPI, antithrombin and protein $\mathrm{C}$ all have a major protective influence ${ }^{99,100}$.

Studies in human volunteers and primates have shown that LPS at low doses induces TF mediated coagulation in an IL-6 dependent manner, while the fibrinolytic response is dependent on TNFalpha $^{100-103,105}$. A second consequence of an increase in pro-inflammatory properties, due to adherence of polymorphonuclear leukocytes to the vascular endothelium, is their degranulation and the formation of reactive oxygen intermediates such as superoxide anion and hydrogen peroxide. This combination of effects promotes tissue necrosis and circulatory collapse.

Thus, it seems likely that in several stages of inflammation, either due to prothrombotic forces or to inflammatory mediated cell activation and apoptosis, MP becomes generated. Indeed, in addition to sepsis MP are detectable in many other inflammatory diseases ${ }^{106}$. The MP generated become properties of activated cells, and expose membrane antigens from the 'parent cell', enabling the determination of their cellular source. The former include alterations in cell membrane composition with a higher degree of negatively charged phosphatidylserine (PS) and phosphatidylethanolamine (PE) residues in the outer membrane as compared to neutral phosphatidylcholine (PC) and sphingomyeline (SM) residues on the inner membrane ${ }^{107}$. Studies showed that the lipid homeostasis is important in the cellular cross-talk of immune cells ${ }^{108}$. Depending on the underlying pathophysiological state, the relative proportions of these MP as well as their antigenic and functional determinants may vary. Based on the fact that in clinical situations with excessive cell death such as malignancies, autoimmune diseases and following chemotherapy high levels of circulating MP might modulate phagocytosing cells, a suppression of the immune response which is cell activation and apoptosis related. Sapet and colleagues showed a novel signalling pathway that emphasizes the proteolytic activity of caspase 2 in endothelial MP generation in response to cell activation ${ }^{108,109}$.

In vivo, the majority of MP detected are from platelet origin (Table 2$)^{90}$. A minor fraction of MP is derived from other cells present in the vasculature, including erythrocytes, granulocytes, monocytes, lymphocytes and endothelial cells. The shift in membrane phospholipid distribution forms the basis for a procoagulant surface. This PS enrichment allows coagulation reactions to take place at the surface of activated cells, particularly platelets, due to the enhanced exposure to the extracellular environment of PS residues ${ }^{87}$. Platelet MP membranes have a 50- to 100fold higher specific procoagulant activity than activated platelets ${ }^{110}$. Also platelet driven MP expose, per unit membrane surface (in vitro), more binding sites for factor Va, VIIIa and IXa than the intact platelet membrane. The net procoagulant effect of MP is however also dependent on other conditions. For instance, although MP-associated TF in platelet concentrates may be a theoretical source of procoagulant activity, the presence of TFPI neutralizes most thrombin generating capacity and this may be just one factor that determines the net procoagulant influence. 
The difference between in vitro potency of MP and in activity in platelet concentrates may also be attributed to the ability of MP to propagate thrombin generation by thrombin-activated $\mathrm{FXI}^{111}$. Theoretically, activation through a factor XII dependent way may contribute to some extent.

The procoagulant properties of MP can be mimicked in vitro, by adding MP fractions to plasma and measuring thrombin generation ${ }^{111,112}$. Initiation requires binding or presence of TF at the membrane surface. In two clinical conditions, MP positive for functionally active TF has been identified. First, in a patient with meningococcal sepsis, ex vivo MP-dependent specific antibodies against TF abolished thrombin generation ${ }^{113}$. Second, these antibodies also inhibited thrombin generation in MP derived from pericardial blood aspired during coronary artery bypass grafting surgery ${ }^{114}$. In contrast, in blood from normal volunteers as well as in other clinical conditions, MP stimulated thrombin generation in TF independent ways ${ }^{90,113}$.

During the last years many studies have addressed the potential biological roles of MP in vivo.

An intriguing interaction between inflammatory cells, MP and coagulation was derived in the ex vivo thrombosis model of the Furie group ${ }^{119-122}$. In a laser induced endothelial injury model they studied thrombus formation with real time imaging and observed the co localization of P-selectin, TF and fibrin after platelet localization in the organizing thrombus ${ }^{123}$. The presence of TF was shown to depend on the availability of P-selectin in this model. MP appeared to form a functional bridge between platelets and monocytes as participants in arterial thrombus formation ${ }^{134}$. Wakefield and colleagues observed that mice with the highest levels of P-selectin in their blood developed the largest venous blood clots and had more inflammatory cells in their vein walls ${ }^{124,125}$. Blood from mice with high levels of P-selectin also contained leukocyte derived MP, but some were derived from blood platelets. Additionally, some MP may have originated from endothelial cells lining vein walls ${ }^{126,127}$.

MP influence endothelial function in several ways. Several studies show a relationship between circulating MP and endothelial function, specifically in diabetes mellitus platelet MP have been linked to development of atherosclerosis ${ }^{117,118}$. Moreover, increased MP shedding from endothelial progenitor cells may reduce circulating endothelial progenitor cell levels and contribute to increased aortic stiffness ${ }^{128,133}$.

Finally, in atherothrombotic disease the induction of vascular cell apoptosis and TF expression may be associated with MP formation that triggers local thrombus formation and contributes to micro-embolization causing downstream ischemia due to no-reflow phenomena ${ }^{129-131}$. MP are more abundant and more thrombogenic in human atherosclerotic plaques than in plasma, which may be related to their different cellular origin ${ }^{115}$. E.g. mononuclear cells convert more efficiently FVII to FVIIa than platelets do ${ }^{116}$. 
Table 2. A summary of various diseases, syndromes and symptoms ranged in alphabetical order associated with increased numbers of MP and their cellular origin(thesis; 2004 R.J.Berckmans).

\begin{tabular}{|c|c|c|}
\hline Diseases & Cellular origin & Reference \\
\hline Acute coronary syndrome & $\begin{array}{l}\text { Platelets, Monocytes / Macrophages, } \\
\text { Endothelial cells, }\end{array}$ & $135,136,137,168$ \\
\hline Antiphospholipid antibody syndrome & Monocytes / Macrophages & 139,140 \\
\hline Arteriosclerosis obliterans & Platelets & 141 \\
\hline Atherosclerotic plaques & Monocytes / Macrophages, Lymphocytes & 142 \\
\hline Cancer & Platelets & 143,144 \\
\hline Cerebral infarct & Platelets & 145,162 \\
\hline Crohn's disease & Platelets & 1467 \\
\hline $\begin{array}{l}\text { Cyanotic congenital heart disease with } \\
\text { polycythemia }\end{array}$ & Platelets & 147 \\
\hline Diabetes Mellitus & Platelets, Endothelial cells & $\begin{array}{l}148,117,149,150 \\
151,152,162\end{array}$ \\
\hline Diabetes mellitus (type 2) & $\begin{array}{l}\text { Monocytes / Macrophages, Granulocytes, } \\
\text { Lymphocytes }\end{array}$ & $150,154,155$ \\
\hline Disseminated intravascular coagulation & Platelets & 153 \\
\hline Hemolytic uremic syndrome & Platelets & 156 \\
\hline Heparin-induced thrombocytopenia & Platelets & $157,158,159,160$ \\
\hline HIV & Lymphocytes & 161 \\
\hline Hypertension (severe) & $\begin{array}{l}\text { Platelets, Monocytes / Macrophages, s } \\
\text { Endothelial cell }\end{array}$ & $162,163,189,190$ \\
\hline Idiopathic nephrotic syndrome & Platelets & 164 \\
\hline Idiopathic thrombocytopenic purpura & Platelets & $165,166,167,207$ \\
\hline Lung cancer & Monocytes / Macrophages & 169 \\
\hline Meningococcal sepsis & Platelets & 113,170 \\
\hline $\begin{array}{l}\text { Multiple organ failure (meningococcal } \\
\text { sepsis) }\end{array}$ & $\begin{array}{l}\text { Monocytes / Macrophages, Leukocytes } \\
\text { (granulocytes) }\end{array}$ & $113,187,188$ \\
\hline Multiple sclerosis & Endothelial cells & 171,172 \\
\hline Myeloproliferative syndrome & Platelets & 173 \\
\hline Myocardial infarction & Platelets ,Endothelial cells & $\begin{array}{l}138,174,175,176 \\
177,178\end{array}$ \\
\hline Paroxysmal noctural hemoglobinuria & Platelets, Endothelial cells & $179,180,181$ \\
\hline
\end{tabular}

Vascular smooth muscle cells may become a pathophysiologically relevant source of TF that can be rapidly exposed to the blood in situations of endothelial damage ${ }^{132}$.

Although many questions remain regarding the involvement of specific MP fractions in thrombosis and other diseases, the cumulative evidence suggests that these cell remnants play a role of importance in many disease states, as summarized in table 2.

\section{Outline of the thesis}

This thesis describes various investigations aimed at aspects of the interactions between inflammation and coagulation. This complex interaction is tackled from a diagnostic perspective, utilizing three different diagnostic assays: for LPS, for procalcitonin and for MP, respectively. We applied these assays to answer specific questions either in animals or in patient populations. 
Chapter II: Involves an economic issue in cattle breeding. To maintain a profitable milk production it is essential that cows are regularly pregnant. When they develop an intra-uterine infection postpartum or even develop dystocia or retain their placenta, the milk production is at risk. We studied the relationship between LPS levels and the development of dystocia or retained placenta in cows by determining the levels of LPS in plasma and lochia compared with blood culture.

Chapter III: Patients undergoing cardiac surgery develop a systemic inflammatory response as a result of the cardiopulmonary bypass procedure. The non-physiological perfusion during the bypass results in a compromised microcirculation in the intestinal barrier, leading to LPS leakage into the systemic circulation. We hypothesized that this same mechanism might occur during extreme exercise. In athletes, ischemia of intestines can develop that may initiate the release of LPS into the circulation. Therefore, we investigated whether after a long exercise, even in healthy and well trained athletes, gastro-intestinal (GI) problems and clinical signs resembling to some extent those of septic patients, are related to a LPS-driven rise in cytokine levels (TNF-alpha and IL-6). The cytokine-triggered acute phase reaction and characteristic variables of this reaction were measured ( $\mathrm{C}$ reactive protein and pre-albumin). Since tissue (muscle) damage can also trigger the cytokine response, creatine kinase was determined as indicator of muscle damage.

Chapter IV: Plasma levels of procalcitonin (PCT) and LPS were measured in samples from athletes (same group of athletes as in chapter 3). As indicated, PCT was claimed to be a new and specific marker for systemic infection and in these subjects it was hypothesized to detect translocation of gram negative bacteria or LPS from the digestive tract.

Chapter V: The efficacy of a new bed-side test for measurements of LPS was determined in a group of septic patients. Since the traditional LAL assay has to be performed under sterile conditions, is relatively slow ( 2 hours), is technically demanding, and is too costly to be performed on multiple patient samples, we tested a rapid bedside test. This SimpliRED ${ }^{\circledR}$ Endotoxin (SRE) assay was tested in 74 patients with documented SIRS. Sepsis was established if the patient also had a positive blood culture. Both the LAL - and the SRE assay were performed and prediction of 28 day-mortality rate was determined.

Chapter VI: Circulating LPS is associated with mortality. Laboratory determination of LPS is still difficult, expensive and technically demanding. The additional value of laboratory assays for LPS, cytokines and PCT to predict patients at risk for fatal outcome is not known. The efficacy of determining these factors on admission to identify patients with a communityacquired infection, who are at risk for an adverse outcome and may benefit from early preventive measures, has not been established. We examined prospectively in febrile patients admitted 
to the Medical Emergency Department the relation between clinical data, levels of plasma endotoxin, TNF-alpha, IL-6, IL-10 and PCT, and outcome.

Chapter VII: Life threatening complications from bacterial infections form a major clinical problem. In severe infections, involving sepsis, the coagulation and fibrinolytic systems are targets for modulation. These cascades are normally activated upon tissue injury and/or blood vessel damage. During infections, inflammatory mediators perturb the pro-coagulant/anticoagulant equilibrium contributing to severe bleeding disorders. We tried to analyze the onset of coagulation disequilibrium by investigating the presence of cell-derived microparticles, as well as their relationship with in vivo coagulation activation and inflammation, in patients suffering from multiple organ dysfunction syndrome and sepsis.

Chapter VIII: Dengue viruses cause a syndrome that varies from mild disease with undifferentiated fever, to dengue hemorrhagic fever, or the potentially lethal dengue shock syndrome. The differentiation between dengue hemorrhagic fever and dengue shock syndrome is made on the basis of clinical and laboratory markers. There is increasing evidence that coagulation abnormalities play an important role in dengue related disease, where increased vascular permeability due to endothelial dysfunction, might lead to TF exposure and a hypercoagulable state. Since it is thought that circulating MP are discerned as sensors for the maintenance of hemostasis they could play a role in dengue shock syndrome. We studied the number and cellular origin of microparticles in 8 patients, 4 with dengue hemorrhagic fever and 4 with dengue shock syndrome.

Chapter IX: Patients with diabetes mellitus type 2 are at relatively high risk for thrombotic events. In this population there is a high incidence of cardiovascular disease due to increased prevalence of risk factors related to coagulation, inflammation and lipoproteins. Studies have shown that increased levels of circulating MP are among the procoagulant determinants in these patients. Treatment with pravastatin (a reductase inhibitor HGM-CoA) in patients with diabetes reduces cardiovascular complications. We studied if pravastatin has any effect on number, cellular origin or antigen composition of microparticles. 


\section{References}

1 van Gestel A., Bakker J., Veraart C.P.W.M., van Hout B.A. Prevalence and incidence of severe sepsis in Dutch intensive care units. Crit Care 2004; 8:R153-R162.

2 Eid A. Doing Antithrombin III an Injustice? Crit Care Med 2005; 33(2):464-465.

3 Dempfle C.E. Disseminated intravascular coagulation and coagulation disorders. Curr Opin Anaesthesiol 2004; 17(2):114-129.

4 Dhainaut J.F., Vallet B. Combined procoagulant and innate immune responses to infection: Toward more potent drugs in septic patients. Crit Care Med 2001; 29(1):205-207.

5 Abraham E. Tissue factor inhibition and clinical trial results of tissue factor pathway inhibitor in sepsis. Crit Care Med 2000; 28(9) Suppl:S31-S33.

6 Banks S.M., Gerstenberger E., Eichacker P.Q., Natanson C. Long-term cost effectiveness of drotrecogin alfa (activated): An unanswered question. Crit Care Med 2003; 31(1):308-309.

7 Mathiak G., Neville L.F., Grass G. Targeting the coagulation cascade in sepsis: Did we find the 'magic bullet'? Crit Care Med 2003; 31(1):310-311.

8 Vincent J.L., Habib A.M., Verdant C., Bruhn A. Sepsis diagnosis and management: work in progress. Minerva Anestesiol 2006; 72:87-96.

9 Angus D.C., Linde-Zwirble W.T., Lidicker J., Clermont G., Carcillo J., Pinsky M.R. Epidemiology of severe sepsis in the United States: Analysis of incidence, outcome, and associated costs of care. Crit Care Med 2001; 29:1303-1310.

10 Greenman R.L., Schein R.M., Martin M.A., Wenzel R.P., MacIntyre N.R., Emmanuel G., Chmel H., Kohler R.B., McCarthy M., Plouffe J., Russell J.A. A controlled clinical trial of E5 murine monoclonal IgM antibody to endotoxin in the treatment of Gram-negative sepsis. The XOMA Sepsis Study Group. The XOMA Sepsis Study Group. JAMA. 1991; 28;266:1097-1102.

11 van Dissel J.T., van Furth R., Compier B.A., Feuth H.D., Frolich M. Survival in selected patients with Gram-negative sepsis after adjunctive therapy with HA-1A. Lancet 1993; 341:959-960.

12 Fisher C.J. Jr., Agosti J.M., Opal S.M., Lowry S.F., Balk R.A., Sadoff J.C., Abraham E., Schein R.M., Benjamin E. Treatment of septic shock with the tumor necrosis factor receptor: Fc fusion protein. The Soluble TNF-ALPHA Receptor Sepsis Study Group. N Engl J Med 1996; 27;334:1697-1702.

13 Ziegler E.J., Fisher C.J.Jr., Sprung C.L.,Sprung C.L., Straube R.C., Sadoff J.C., Foulke G.E., Wortel C.H., Fink M.P., Dellinger R.P., Teng N.N. Allen I.E., Berger H.J.,Knatterud G.L., LoBuglio A.F., Smith C.R. Treatment of Gram-negative bacteremia and septic shock with HA-1A human monoclonal antibody against endotoxin. A randomized, double-blind, placebo-controlled trial. The HA-1A Sepsis Study Group. N Engl J Med 1991; 14;324:429-436.

14 Kiani A., Tschiersch A., Gaboriau E., Otto F., Seiz A., Knopf H.P., Stutz P., Farber L., Haus U., Galanos C., Mertelsmann R., Engelhardt R. Downregulation of the proinflammatory cytokine response to endotoxin by pretreatment with the nontoxic Lipid A analog SDZ MRL 953 in cancer patients. Blood 1997; 15;90:1673-1683.

15 Polderman K.H., Girbes A.R. Drug intervention trials in sepsis: divergent results. Lancet 2004; 363:1721-3.

16 Cross A.S., Opal S.M. A new paradigm for the treatment of sepsis: is it time to consider combination therapy? Arch Intern Med 2003; 138:502-5.

17 Warren B.L., Eid A., Singer P., Pillay S.S., Carl P., Novak I., Chalupa P., Atherstone A., Penzes I., Kubler A., Knaub S., Keinecke H.O., Heinrichs H., Schindel F., Juers M., Bone R.C., Opal S.M. KyberSept Trial Study Group. Caring for the critically ill patient. High-dose antithrombin III in severe sepsis: a randomized controlled trial. JAMA 2001; 286:1869-78.

18 Wiedermann C.J. Clinical review: Molecular mechanisms underlying the role of antithrombin in sepsis. Crit Care 2006; 10:209.

19 Kienast J., Juers M., Wiedermann C.J., Hoffmann J.N., Ostermann H., Strauss R., Keinecke H.O., Warren B.L., Opal S.M., for the KyberSept investigators. Treatment effects of high-dose antithrombin 
without concomitant heparin in patients with severe sepsis with or without disseminated intravascular coagulation. J Thromb Haemost 2006; 4:90-7.

20 Loubele S., ten Cate H. Commentary: Local administration of a recombinant human antithrombin in a mouse model of peritoneal sepsis. J Thromb Haemost 2006; 4(11):2340-2.

21 Bernard G.R., Vincent J.L., Laterre P.F., LaRosa S.P., Dhainaut J.F., Lopez-Rodriguez A., Steingrub J.S., Garber G.E., Helterbrand J.D., Ely E.W., Fisher C.J.Jr. Recombinant human protein C Worldwide Evaluation in Severe Sepsis (PROWESS) study group. Efficacy and safety of recombinant human activated protein C for severe sepsis. N Engl J Med 2001; 344:699-709.

22 Levi M.M., ten Cate H.Disseminated intravascular coagulation. New Engl J Med 1999; 341(8):586-92.

23 Freyssinet J.M. Cellular microparticles: what are they bad or good for?J Thromb Haemost 2003; 1(7):1655-62.

24 Diamant M., Tushuizen M.E., Sturk A., Nieuwland R. Cellular microparticles: new players in the field of vascular disease? Eur J Clin Invest 2004; 34(6):392-401.

25 Pfiffer R. Untersuchungen uber das choleragift. Z Hygiene 1892; 11:393-412.

26 Westphal O., Jann K., Himmelspach K. Chemistry and immunochemistry of bacterial lipopolysaccharides as cell wall antigens and endotoxins. Prog Allergy 1983; 33:9-39.

27 Munford R.S., Varley A.W. Shield as signal: lipoplysaccharides and the evolution of immunity to Gramnegative bacteria. Plos Pathogens 2006; 2:0467-71.

28 Wollenweber H.W., Broady K.W., Luderitz O., Rietschel E.T. The chemical structure of lipid A. Demonstration of amide-linked 3-acyloxyacyl residues in Salmonella minnesota Re lipopolysaccharide. Eur J Biochem 1982; 124(1):191-8.

29 Tesh V.L., Vukajlovich S.W., Morrison D.C. Endotoxin interactions with serum proteins relationship to biological activity. Prog Clin Biol Res 1988; 272:47-62.

30 Warren H.S., Riveau G.R., de Deckker F.A., Chedid L.A. Control of endotoxin activity and interleukin-1 production through regulation of lipopolysaccharide-lipoprotein binding by a macrophage factor. Infect Immun 1988; 56(1):204-12.

31 Harris H.W., Grunfeld C., Feingold K.R., Rapp J.H. Human very low density lipoproteins and chylomicrons can protect against endotoxin-induced death in mice. J Clin Invest 1990; 86(3):696-702.

32 Gazzano-Santoro H., Parent J.B., Grinna L., Horwitz A., Parsons T., Theofan G., Elsbach P., Weiss J., Conlon P.J. High-affinity binding of the bactericidal/permeability-increasing protein and a recombinant amino-terminal fragment to the lipid A region of lipopolysaccharide. Infect Immun 1992; 60(11):475461.

33 Weiss J., Victor M., Stendhal O., Elsbach P. Killing of gram-negative bacteria by polymorphonuclear leukocytes: role of an O2-independent bactericidal system. J Clin Invest 1982; 69(4):959-70.

34 Tobias P.S., Mathison J.C., Ulevitch R.J. A family of lipopolysaccharide binding proteins involved in responses to gram-negative sepsis. J Biol Chem 1988; 263(27):13479-81.

35 Schumann R.R., Leong S.R., Flaggs G.W., Gray P.W., Wright S.D., Mathison J.C., Tobias P.S., Ulevitch R.J. Structure and function of lipopolysaccharide binding protein. Science 1990; 249(4975):1429-31.

36 van Dissel J.T., van Langevelde P., Westendorp R.G., Kwappenberg K., Frolich M. Anti-inflammatory cytokine profile and mortality in febrile patients. Lancet 1998; 351(9107):950-3.

37 Carrol E.D., Thomson A.P., Jones A.P., Jeffers G., Hart C.A. A predominantly anti-inflammatory cytokine profile is associated with disease severity in meningococcal sepsis. Intensive Care Med 2005; 31(10):1415-9.

38 Hoffman W.D., Natanson C. Endotoxin in septic shock. Anesth Analg 1993; 77(3):613-24.

39 Hoebe K., Janssen E., Beutler B. The interface between innate and adaptive immunity. Nat Immunol 2004; 5(10):971-4.

40 Skidmore B.J., Chiller J.M., Weigle W.O., Riblet R., Watson J. Immunologic properties of bacterial lipopolysaccharide (LPS). III. Genetic linkage between the in vitro mitogenic and in vivo adjuvant properties of LPS. J Exp Med 1976; 143(1):143-50.

41 Skidmore B.J., Chiller J.M., Morrison D.C., Weigle W.O. Immunologic properties of bacterial 
lipopolysaccharide (LPS): correlation between the mitogenic, adjuvant, and immunogenic activities. J Immunol 1975; 114:770-5.

42 Jiang Z., Georgel P., Du X., Shamel L., Sovath S., Mudd S., Huber M., Kalis C., Keck S., Galanos C., Freudenberg M., Beutler B. CD14 is required for MyD88-independent LPS signalling. Nat Immunol 2005; 6(6):565-70.

43 Levi M., van der Poll T., ten Cate H., van Deventer S.J. The cytokine-mediated imbalance between coagulant and anticoagulant mechanisms in sepsis and endotoxemia. Eur J Clin Invest. 1997; 27(1): 3-9.

44 Bang F.B. A bacterial disease of Limulus polyphemus. Bull Johns Hopkins Hosp 1956; 98(5):325-51.

45 Levin J., Bang F.B. A description of cellular coagulation in the Limulus. Bull Johns Hopkins Hosp $1964 ; 115: 337-45$.

46 Shuster C.N.Jr. A pictorial review of the natural history and ecology of the horseshoe crab Limulus polyphemus, with reference to other Limulidae. Prog Clin Biol Res 1982; 81:1-52.

47 Segukuchi K. 'Hemocytes and Coagulogen, A coagulation factor' Biology of Horseshoe Crabs. 1988; 334-8.

48 Thomas L.L., Henny C.P., Buller H.R., Sturk A., Joop K., ten Cate J.W. Chromogenic endotoxin determination in blood-clinical relevance. Klin Wochenschr 1982; 60(14):759-60.

49 Friberger P., Knos M., Mellstam L. A quantitative endotoxin assay utilizing LAL and a chromogenic substrate. Prog Clin Biol Res 1982; 93:195-206.

50 Ross V.C., Bruch C.W. Endotoxin testing of medical devices with LAL: FDA requirements. Prog Clin Biol Res 1982; 93:39-48.

51 Friberger P. The design of a reliable endotoxin test. Prog Clin Biol Res 1985; 189:139-49.

52 Sturk A., Joop K., ten Cate J.W., Thomas L.L. Optimalization of a chromogenic assay for endotoxin in blood. Prog Clin Biol Res 1985; 189:117-37.

53 Mürer E.H., Levin J., Holm R. Isolation and studies of the granules of the ameobocytes of Limulus polyphemus, the horseshoe crab. J Cell Physiol 1975; 86:533-542.

54 Quigley J.P., Corcoran G., Armstrong P.B. A Hemolytic Activity Secreted by the Endotoxin-Challenged Horseshoe Crab: A Novel Immune System Operating at the Surface of the Carapace. Biological Bulletin 1997; 193:273.

55 Sargent W. The Year of the Crab. W.W. Norton \& Company 1987.

56 Ratnoff O.D. The Evolution of Knowledge about Hemostasis. In: Disorders of Hemostasis. Ratnoff O.D. Forbes C.D. 3rd edition. WB Saunders Company Philadelphia 1996.

57 Joyce C.D., Fiscus R.R., Wang X., Dries D.J., Morris R.C., Prinz R.A. Calcitonin gene-related peptide levels are elevated in patients with sepsis. Surgery 1990; 108(6):1097-101.

58 Dandona P., Nix D., Wilson M.F., Aljada A., Love J., Assicot M., Bohuon C. Procalcitonin increase after endotoxin injection in normal subjects . J Clin Endocrinol Metab 1994; 79(6):1605-8.

59 Viallon A., Guyomarc'h P., Guyomarc'h S., Tardy B., Robert F., Marjollet O., Caricajo A., Lambert C., Zéni F., Bertrand J.C. Decrease in serum procalcitonin levels over time during treatment of acute bacterial meningitis. Crit Care 2005; 9(4):R344-50.

60 Viallon A., Zeni F., Lambert C., Pozzetto B., Tardy B., Venet C., Bertrand J.C. High sensitivity and specificity of serum procalcitonin levels in adults with bacterial meningitis. Clin Infect Dis 1999; 28(6):1313-6.

61 Christ-Crain M., Müller B. Procalcitonin and Pneumonia: Is it a Useful Marker? Curr Infect Dis Rep 2007; 9(3):233-40.

62 Kushimoto S., Shibata Y., Koido Y., Kawai M., Yokota H., Yamamoto Y. The clinical usefulness of procalcitonin measurement for assessing the severity of bacterial infection in critically ill patients requiring corticosteroid therapy. J Nippon Med Sch 2007; 74(3):236-40.

63 Novotny A., Emmanuel K., Matevossian E., Kriner M., Ulm K., Bartels H., Holzmann B., Weighardt H., Siewert J.R. Use of procalcitonin for early prediction of lethal outcome of postoperative sepsis. Am J Surg 2007; 194(1):35-9. 
64 Rau B.M. Predicting severity of acute pancreatitis. Curr Gastroenterol Rep 2007; 9(2):107-15.

65 Rau B.M., Kemppainen E.A., Gumbs A.A., Büchler M.W., Wegscheider K., Bassi C., Puolakkainen P.A., Beger H.G. Early assessment of pancreatic infections and overall prognosis in severe acute pancreatitis by procalcitonin (PCT): a prospective international multicenter study. Ann Surg 2007; 245(5):745-54.

66 Fioretto J.R., Borin F.C., Bonatto R.C., Ricchetti S.M., Kurokawa C.S., de Moraes M., Carpi M.F., Padovani C.R., Martin J.G. Procalcitonin in children with sepsis and septic shock. J Pediatr (Rio J) 2007; 83(4):323-8.

67 Gaïni S., Koldkjær O.G., Møller H.J., Pedersen C., Pedersen S.S. A comparison of high-mobility groupbox 1 protein, lipopolysaccharide-binding protein and procalcitonin in severe community-acquired infections and bacteraemia: a prospective study. Crit Care. 2007; 11(4).

68 Macfarlane R.G. An enzyme cascade in the blood clotting mechanism, and its function as a biochemical amplifier. Nature 1964; 202:498-9.

69 Davie E.W., Ratnoff O.D. Waterfall sequence for intrinsic blood clotting. Science 1964; 145:1310-2.

70 Hemker H.C., Kahn M.J. Reaction sequence of blood coagulation. Nature 1967; 215(106):1201-2.

71 Barton P.G. The influence of surface charge density of phosphatides on the binding of some cations. J Biol Chem 1968; 243(14):3884-90.

72 sterud B., Rapaport S.I. Synthesis of intrinsic factor X activator. Inhibition of the function of formed activator by antibodies to factor VIII and to factor IX. Biochemistry 1970; 9(8):1854-1861.

73 Ratnoff O.D., Margolius A. Hageman factor and Hageman trait. In: Hemophilia and hemophiliod diseases. Brinkhous K.M. e.d. Univ North Carolina Press, Chapel Hill 1957; 12.

74 Rosebthal R.L. Properties of plasma thromboplastin antecedent (PTA) in relation to blood coagulation. J Lab Clin Med 1955; 45(1):123-9.

75 Biggs R., Nossel H.L. Tissue extract and the contact reaction of blood coagulation. Thromb. Diath. Haemorrh 1961; 6:1-14.

76 Josso F., Prou-Wartelle O. Interaction of tissue factor and factor VII at the earliest phase of coagulation. Thromb Diath. Haermorrh 1964; Suppl:17:35-44.

77 sterud B., Rapaport S.I. Activation of factor IX by the reaction product of tissue factor VII: Additional pathway for initiating blood coagulation. Proc Natl Acad Sci USA 1977; 74:5260-5264.

78 Rapaport S.I., Rao L.V. The tissue factor pathway: how it has become a 'prima ballerina'. Thromb Haemost 1995; 74(1):7-17.

79 Wang W., Hendriks D.F., Scharpe S.S. Carboxypeptidase U, a plasma carboxypeptidase with high affinity for plasminogen. J Biol Chem 1994; 269(22):15937-44.

80 Bertina R.M., van Tilburg N.H., Haverkate F., Bouma B.N., von dem Borne P.A., Meijers J.C., Campbell W., Eaton D., Hendriks D.F., Willemse J.L. Discovery of thrombin activatable fibrinolysis inhibitor (TAFI). J Thromb Haemost 2006; 4(1):256-7.

81 Renne T., Pozgajova M., Gruner S., Schuh K., Pauer H.U., Burfeind P., Gailani D., Nieswandt B. Defective thrombus formation in mice lacking coagulation factor XII. J Exp Med 2005; 202(2):271-81.

82 Spronk H.M.H., Govers-Riemslag J., ten Cate H. Blood coagulation as a molecular machine. Bioessays 2003; 25(12): 1220-8.

83 Egeberg O. Thrombophilia caused by inheritable deficiency of blood antithrombin. Scand J Clin Lab Invest 1965; 17:92.

84 Esmon C.T. The protein C pathway. Chest 2003; 124:3Suppl:26S-32S.

85 Broze G.J.Jr., Likert K., Higuchi D. Inhibition of factor VIIa/tissue factor by antithrombin III and tissue factor pathway inhibitor. Blood 1993; 82(5):1679-81.

86 Hoffman M., Monroe III D.M. The action of high-dose factor VIIa (FVIIa) a cell-based model of hemostasis. In: Treatment of Bleeding and Thrombotic Disorders. Semi Hematology 2001; Suppl.

87 Taylor F.B.Jr., He S.E., Chang A.C., Box J., Ferrell G., Lee D., Lockhart M., Peer G., Esmon C.T. Infusion of phospholipid vesicles amplifies the local thrombotic response to TNF-ALPHA and antiprotein C into a consumptive response. Thromb Haemost 1996; 75(4):578-84. 
88 Chargaff E., West R. The biological significance of the thromboplastic protein of blood. J Biol Chem 1946; 166:189 -97.

89 O’Bran J.R. The platelet-like activity of serum. Br J Haematol 1955; 1:223-8.

90 Wolf P. The nature and significance of platelet products in human plasma. Br J Haematol 1967; 13:269-88.

91 Jy W., Mao W.W., Horstman L., Tao J., Ahn Y.S. Platelet microparticles bind, activate and aggregate neutrophils in vitro. Blood Cells Mol Dis 1995; 21(3):217-31.

92 VanWijk M.J., VanBavel E., Sturk A., Nieuwland R. Microparticles in cardiovascular diseases. Cardiovasc Res 2003; 59(2):277-87.

93 Freyssinet J.M. Cellular microparticles: what are they bad or good for? J Thromb Haemost. 2003; 1(7):1655-62.

94 Noggle T.S., Stiegler J.O. Electron Microscope Observations of Fission Fragment Tracks in Thin Films of UO2. Solid State Division, Oak Ridge National Laboratory, Oak Ridge, Tennessee Journal of Applied Physics 1960; (31) 12,2199-2208.

95 Stiegler J.O., Noggle T.S. Victawet and Sodium Metaphosphate as Parting Agents for Electron Microscope Replicas Solid State Division, Oak Ridge National Laboratory, Oak Ridge, Tennessee. Review of Scientific Instruments 1961; 32(4):406-408.

96 Coleman M.L., Sahai E.A., Yeo M., Bosch M., Dewar A., Olson M.F. Membrane blebbing during apoptosis results from caspase-mediated activation of ROCK I. Nat Cell Biol 2001; 3(4):339-45.

97 Levi M., Keller T.T., van Gorp E.C.M., ten Cate H. Infection and inflammation and the coagulation system. Cardiovasc Res 2003; 60:(1)26-39.

98 Taylor F.B.Jr. Staging of the pathophysiologic responses of the primate microvasculature to Escherichia coli and endotoxin: Examination of the elements of the compensated response and their links to the corresponding uncompensated lethal variants. Crit Care Med 2001; 29:S78- S89.

99 Taylor F.B. Jr. Response of anticoagulant pathways in disseminated intravascular coagulation. Semin Thromb Hemost 2001; 27(6):619-31.

100 Bajaj M.S., Ghosh M., Bajaj S.P. Fibronectin-adherent monocytes express tissue factor and tissue factor pathway inhibitor whereas endotoxin-stimulated monocytes primarily express tissue factor: physiologic and pathologic implications. J Thromb Haemost 2007; 5(7):1493-9.

101 Levi M., ten Cate H., van der Poll T., van Deventer S.J. Pathogenesis of disseminated intravascular coagulation in sepsis. JAMA 1993; 270(8)975-979.

102 de Jonge E., Dekkers P.E., Creasey A.A., Hack C.E., Paulson S.K., Karim A., Kesecioglu J., Levi M., van Deventer S.J., van der Poll T. Tissue factor pathway inhibitor dose-dependently inhibits coagulation activation without influencing the fibrinolytic and cytokine response during human endotoxemia. Blood 2000; 95(4):1124-9.

103 O'Brien J.M.Jr., Abraham E. Human models of endotoxemia and recombinant human activated protein C. Crit Care Med 2004; 32(5 Suppl):S202-8.

104 van der Poll T., Levi M., Hack C.E., ten Cate H., van Deventer S.J., Eerenberg A.J., de Groot E.R., Jansen J., Gallati H., Buller H.R., ten Cate J.W., van Aareden L.A. Elimination of interleukin 6 attenuates coagulation activation in experimental endotoxemia in chimpanzees. J Exp Med 1994; 179(4):1253-9.

105 van der Poll T., Levi M., Buller H.R., van Deventer S.J., de Boer J.P., Hack C.E., ten Cate J.W. Fibrinolytic response to tumor necrosis factor in healthy subjects. J Exp Med 1991; 174(3):729-32.

106 Berckmans R.J., Nieuwland R., Tak P.P., Boing A.N., Romijn F.P., Kraan M.C., Breedveld F.C., Hack C.E., Sturk A. Cell-derived microparticles in synovial fluid from inflamed arthritic joints support coagulation exclusively via a factor VII-dependent mechanism. Arthritis Rheum 2002; 46(11):285766.

107 Zwaal R.F., Schroit A.J. Pathophysiologic implications of membrane phospholipid asymmetry in blood cells. Blood 1997; 89(4):1121-32.

108 Sapet C., Simoncini S., Loriod B., Puthier D., Sampol J., Nguyen C., Dignat-George F., Anfosso F. 
Thrombin-induced endothelial microparticle generation: identification of a novel pathway involving ROCK-II activation by caspase-2. Blood 2006; 108(6):1868-76.

109 Huber L.C., Jüngel A., Distler J.H., Moritz F., Gay R.E., Michel B.A., Pisetsky D.S., Gay S., Distler $\mathrm{O}$. The role of membrane lipids in the induction of macrophage apoptosis by microparticles. Apoptosis 2007; 12(2):363-74.

110 Sinauridze E.I., Kireev D.A., Popenko N.Y., Pichugin A.V., Panteleev M.A., Krymskaya O.V., Ataullakhanov F.I. Platelet microparticle membranes have 50- to 100-fold higher specific procoagulant activity than activated platelets. Thromb Haemost 2007; 97(3):425-34.

111 Keuren J.F., Magdeleyns E.J., Govers-Riemslag J.W., Lindhout T., Curvers J. Effects of storageinduced platelet microparticles on the initiation and propagation phase of blood coagulation. $\mathrm{Br} \mathrm{J}$ Haematol 2006; 134(3):307-13.

112 Cauwenberghs S., Feijge M.A., Harper A.G., Sage S.O., Curvers J., Heemskerk J.W. Shedding of procoagulant microparticles from unstimulated platelets by integrin-mediated destabilization of actin cytoskeleton. FEBS Lett 2006; 580(22):5313-20.

113 Nieuwland R., Berckmans R.J., McGregor S., Boing A.N., Romijn F.P., Westendorp R.G., Hack C.E., Sturk A. Cellular origin and procoagulant properties of microparticles in meningococcal sepsis. Blood 2000; 95(3):930-5.

114 Nieuwland R., Berckmans R.J., Rotteveel-Eijkman R.C., Maquelin K.N., Roozendaal K.J., Jansen P.G., ten Have K., Eijsman L., Hack C.E., Sturk A. Cell-derived microparticles generated in patients during cardiopulmonary bypass are highly procoagulant. Circulation 1997; 96(10):353441.

115 Leroyer A.S., Isobe H., Lesèche G., Castier Y., Wassef M., Mallat Z., Binder B.R., Tedgui A., Boulanger C.M.J. Cellular origins and thrombogenic activity of microparticles isolated from human atherosclerotic plaques. Am Coll Cardiol 2007; 49(7):772-7.

116 Khan M.M., Hattori T., Niewiarowski S., Edmunds L.H.Jr., Colman R.W. Truncated and microparticle-free soluble tissue factor bound to peripheral monocytes preferentially activate factor VII. Thromb Haemost 2006; 95(3):462-8.

117 Nomura S., Suzuki M., Katsura K., Xie G,L., Miyazaki Y., Miyake T., Kido H., Kagawa H., Fukuhara S. Platelet-derived microparticles may influence the development of atherosclerosis in diabetes mellitus. Atherosclerosis 1995; 116(2):235-40.

118 Morel O., Hugel B., Jesel L., Lanza F., Douchet M.P., Zupan M., Chauvin M., Cazenave J.P., Freyssinet J.M., Toti F. Sustained elevated amounts of circulating procoagulant membrane microparticles and soluble GPV after acute myocardial infarction in diabetes mellitus.. Thromb Haemost 2004; 91(2):345-53.

119 Sim D., Flaumenhaft R., Furie B., Furie B. Interactions of platelets, blood-borne tissue factor, and fibrin during arteriolar thrombus formation in vivo. Microcirculation 2005; 12(3):301-11.

120 Furie B., Furie B.C. Role of platelet P-selectin and microparticle PSGL-1 in thrombus formation. Trends Mol Med 2004; 10(4):171-8.

121 Celi A., Lorenzet R., Furie B.C., Furie B-C. Microparticles and a P-selectin-mediated pathway of blood coagulation. Dis Markers 2004; 20(6):347-52.

122 Furie B. P-selectin and blood coagulation: it's not only about inflammation any more. Arterioscler Thromb Vasc Biol 2005; 25(5):877-8.

123 Falati S., Liu Q., Gross P., Merrill-Skoloff G., Chou J., Vandendries E., Celi A., Croce K., Furie B.C., Furie B. Accumulation of tissue factor into developing thrombi in vivo is dependent upon microparticle P-selectin glycoprotein ligand 1 and platelet P-selectin. J Exp Med 2003; 2:197(11):1585-98.

124 Myers D.D., Hawley A.E., Farris D.M., Wrobleski S.K., Thanaporn P., Schaub R.G., Wagner D.D., Kumar A., Wakefield T.W. P-selectin and leukocyte microparticles are associated with venous thrombogenesis. J Vasc Surg 2003; 38(5):1075-89.

125 Myers D.D.Jr., Rectenwald J.E., Bedard P.W., Kaila N., Shaw G.D., Schaub R.G., Farris D.M., 
Hawley A.E., Wrobleski S.K., Henke P.K., Wakefield T.W. Decreased venous thrombosis with an oral inhibitor of P selectin. J Vasc Surg 2005; 42(2):329-36.

126 Day S.M., Reeve J.L., Myers D.D., Fay W.P. Murine thrombosis models. Thromb Haemost 2004; 92(3):486-94.

127 Williams J.B., Jauch E.C., Lindsell C.J., Campos B. Endothelial microparticle levels are similar in acute ischemic stroke and stroke mimics due to activation and not apoptosis/necrosis. Acad Emerg Med 2007; 14(8):685-90.

128 Arteaga R.B., Chirinos J.A., Soriano A.O., Jy W., Horstman L., Jimenez J.J., Mendez A., Ferreira A., de Marchena E., Ahn Y.S. Endothelial microparticles and platelet and leukocyte activation in patients with the metabolic syndrome. Am J Cardiol 2006; 98(1):70-4.

129 Bonderman D., Teml A., Jakowitsch J., Adlbrecht C., Gyongyosi M., Sperker W., Lass H., Mosgoeller W., Glogar D.H., Probst P., Maurer G., Nemerson Y., Lang I.M. Coronary no-reflow is caused by shedding of active tissue factor from dissected atherosclerotic plaque. Blood 2002; 99(8):2794-800.

130 Viles-Gonzalez J.F., Fuster V., Badimon J.J. Thrombin/inflammation paradigms: a closer look at arterial and venous thrombosis. Am Heart J 2005; Suppl:1:S19-31.

131 Hutter R., Valdiviezo C., Sauter B.V., Savontaus M., Chereshnev I., Carrick F.E., Bauriedel G., Luderitz B., Fallon J.T., Fuster V., Badimon J.J. Caspase-3 and tissue factor expression in lipid-rich plaque macrophages: evidence for apoptosis as link between inflammation and atherothrombosis. Circulation 2004; 109(16):2001-8.

132 Stampfuss J.J., Censarek P., Fischer J.W., Schrör K., Weber A.A. Rapid release of active tissue factor from human arterial smooth muscle cells under flow conditions. Arterioscler Thromb Vasc Biol 2006; 26(5):e34-7.

133 Pirro M., Schillaci G., Bagaglia F., Menecali C., Paltriccia R., Mannarino M.R., Capanni M., Velardi A., Mannarino E. Microparticles derived from endothelial progenitor cells in patients at different cardiovascular risk. Atherosclerosis 2008; 197(2):757-67.

134 Lok C.A., Nieuwland R., Sturk A., Hau C.M., Boer K., Vanbavel E., Van der post J.A. Microparticleassociated P-selectin reflects platelet activation in preeclampsia. Platelets 2007; 18(1):68-72.

135 Mallat Z., Hugel B., Ohan J., Leseche G., Freyssinet J.M., Tedgui A. Shed membrane microparticles with procoagulant potential in human atherosclerotic plaques: a role for apoptosis in plaque thrombogenicity. Circulation 1999; 99(3):348-53.

136 Matsumoto N., Nomura S., Kamihata H., Kimura Y., Iwasaka T. Increased level of oxidized LDLdependent monocyte-derived microparticles in acute coronary syndrome. Thromb Haemost 2004; 91(1):146-54.

137 Bernal-Mizrachi L., Jy W., Jimenez J.J., Pastor J., Mauro L.M., Horstman L.L., de Marchena E., Ahn Y.S. High levels of circulating endothelial microparticles in patients with acute coronary syndromes. Am Heart J 2003; 145(6):962-70.

138 Morel O., Jesel L., Hugel B., Douchet M.P., Zupan M., Chauvin M., Freyssinet J.M., Toti F. Protective effects of vitamin $\mathrm{C}$ on endothelium damage and platelet activation during myocardial infarction in patients with sustained generation of circulating microparticles. J Thromb Haemost 2003; 1(1):171-7.

139 Dignat-George F., Camoin-Jau L., Sabatier F., Arnoux D., Anfosso F., Bardin N., Veit V., Combes V., Gentile S., Moal V., Sanmarco M., Sampol J. Endothelial microparticles: a potential contribution to the thrombotic complications of the antiphospholipid syndrome. Thromb Haemost 2004; 91(4):66773.

140 Nagahama M., Nomura S., Kanazawa S., Ozaki Y., Kagawa H., Fukuhara S. Significance of antioxidized LDL antibody and monocyte-derived microparticles in anti-phospholipid antibody syndrome. Autoimmunity 2003; 36(3):114-31.

141 Nomura S., Imamura A., Okuno M., Kamiyama Y., Fujimura Y., Ikeda Y., Fukuhara S. Plateletderived microparticles in patients with arteriosclerosis obliterans: enhancement of high shear-induced microparticle generation by cytokines. Thromb Res 2000; 98(4):257-68.

142 Mallat Z., Hugel B., Ohan J., Leseche G., Freyssinet J.M., Tedgui A. Shed membrane microparticles 
with procoagulant potential in human atherosclerotic plaques: a role for apoptosis in plaque thrombogenicity. Circulation 1999; 99(3):348-53.

143 Kanazawa S., Nomura S., Kuwana M., Muramatsu M., Yamaguchi K., Fukuhara S. Monocyte-derived microparticles may be a sign of vascular complication in patients with lung cancer. Lung Cancer 2003; 39(2):145-9.

144 Kim H.K., Song K.S., Park Y.S., Kang Y.H., Lee Y.J., Lee K.R., Kim H.K., Ryu K.W., Bae J.M., Kim S. Elevated levels of circulating platelet microparticles, VEGF, IL-6 and RANTES in patients with gastric cancer: possible role of a metastasis predictor. Eur J Cancer 2003; 39(2):184-91.

145 Lee Y.J., Jy W., Horstman L.L., Janania J., Reyes Y., Kelley R.E., Ahn Y.S., Chamouard P., Desprez D., Hugel B., Kunzelmann C. Elevated platelet microparticles in transient ischemic attacks, lacunar infarcts, and multiinfarct dementias. Thromb Res 1993; 72(4):295-304.

146 Gidon-Jeangirard C., Lessard M., Baumann R., Freyssinet J.M., Grunebaum L. Circulating cellderived microparticles in Crohn's disease. Dig Dis Sci 2005; 50(3):574-80.

147 Horigome H., Hiramatsu Y., Shigeta O., Nagasawa T., Matsui A. Overproduction of platelet microparticles in cyanotic congenital heart disease with polycythemia. J Am Coll Cardiol 2002; 39(6):1072-7.

148 Sabatier F., Darmon P., Hugel B., Combes V., Sanmarco M., Velut J.G., Arnoux D., Charpiot P., Freyssinet J.M., Oliver C., Sampol J., Dignat-George F. Type 1 and type 2 diabetic patients display different patterns of cellular microparticles. Diabetes 2002; 51(9):2840-5.

149 Morel O., Hugel B., Jesel L., Lanza F., Douchet M.P., Zupan M., Chauvin M., Cazenave J.P., Freyssinet J.M., Toti F. Sustained elevated amounts of circulating procoagulant membrane microparticles and soluble GPV after acute myocardial infarction in diabetes mellitus. Thromb Haemost 2004; 91(2):345-53.

150 Nomura S., Kanazawa S., Fukuhara S. Effects of eicosapentaenoic acid on platelet activation markers and cell adhesion molecules in hyperlipidemic patients with Type 2 diabetes mellitus. J Diabetes Complications 2003; 17(3):153-9.

151 Cohen Z., Gonzales R.F., Davis-Gorman G.F., Copeland J.G., McDonagh P.F. Thrombin activity and platelet microparticle formation are increased in type 2 diabetic platelets: a potential correlation with caspase activation. Thromb Res 2002; 107(5):217-21.

152 Gabbianelli R., Falcioni G., Dow C.S., Vince F.P., Swoboda B. A new method to evaluate spontaneous platelet aggregation in type 2 diabetes by Cellfacts. Clin Chim Acta 2003; 329(1-2):95-102.

153 Holme P.A., Solum N.O., Brosstad F., Roger M., Abdelnoor M. Demonstration of platelet-derived microvesicles in blood from patients with activated coagulation and fibrinolysis using a filtration technique and western blotting. Thromb Haemost 1994; 72(5):666-71.

154 Diamant M., Nieuwland R., Pablo R.F., Sturk A., Smit J.W., Radder J.K. Elevated numbers of tissue-factor exposing microparticles correlate with components of the metabolic syndrome in uncomplicated type 2 diabetes mellitus. Circulation 2002; 106(19):2442-7.

155 Omoto S., Nomura S., Shouzu A., Nishikawa M., Fukuhara S., Iwasaka T. Detection of monocytederived microparticles in patients with Type II diabetes mellitus. Diabetologia 2002; 45(4):550-5.

156 Galli M., Grassi A., Barbui T. Platelet-derived microvesicles in thrombotic thrombocytopenic purpura and hemolytic uremic syndrome. Thromb Haemost 1996; 75(3):427-31.

157 Hughes M., Hayward C.P., Warkentin T.E., Horsewood P., Chorneyko K.A., Kelton J.G. Morphological analysis of microparticle generation in heparin-induced thrombocytopenia. Blood 2000; 96(1):188-94.

158 Reilly R.F. The pathophysiology of immune-mediated heparin-induced thrombocytopenia. Semin Dial 2003; 16(1):54-60.

159 Kelton J.G. Heparin-induced thrombocytopenia: an overview. Blood Rev 2002; 16(1):77-80.

160 Warkentin T.E. Heparin-induced thrombocytopenia: a ten-year retrospective. Annu Rev Med 1999; 50:129-47.

161 Aupeix K., Hugel B., Martin T., Bischoff P., Lill H, Pasquali J.L., Freyssinet J.M. The significance 
of shed membrane particles during programmed cell death in vitro, and in vivo, in HIV-1 infection. J Clin Invest 1997; 99(7):1546-54.

162 Nomura S., Komiyama Y., Miyake T., Miyazaki Y., Kido H., Suzuki M., Kagawa H., Yanabu M., Takahashi H., Fukuhara S. Amyloid beta-protein precursor-rich platelet microparticles in thrombotic disease. Thromb Haemost 1994; 72(4):519-22.

163 Preston R.A., Jy W., Jimenez J.J., Mauro L.M., Horstman L.L., Valle M., Aime G., Ahn Y.S. Effects of severe hypertension on endothelial and platelet microparticles. Hypertension 2003; 41(2):211-7.

164 Tkaczyk M., Baj Z. Surface markers of platelet function in idiopathic nephrotic syndrome in children. Pediatr Nephrol 2002; 17(8):673-7.

165 Jy W., Horstman L.L., Arce M., Ahn Y.S. Clinical significance of platelet microparticles in autoimmune thrombocytopenias. J Lab Clin Med 1992; 119(4):334-45.

166 Nomura S., Yanabu M., Kido H., Fukuroi T., Yamaguchi K., Soga T., Nagata H., Kokawa T., Yasunaga K. Antiplatelet autoantibody-related microparticles in patients with idiopathic (autoimmune) thrombocytopenic purpura. Ann Hematol 1991; 62(4):103-7.

167 Ahn Y.S., Horstman L.L. Idiopathic thrombocytopenic purpura: pathophysiology and management. Int J Hematol 2002; 76 Suppl:2:123-31.

168 Katopodis J.N., Kolodny L., Jy W., Horstman L..L., De Marchena E.J., Tao J.G., Haynes D.H., Ahn Y.S. Platelet microparticles and calcium homeostasis in acute coronary ischemias. Am J Hematol 1997; 54(2):95-101.

169 Kanazawa S., Nomura S., Kuwana M., Muramatsu M., Yamaguchi K., Fukuhara S. Monocyte-derived microparticles may be a sign of vascular complication in patients with lung cancer. Lung Cancer 2003; 39(2):145-9.

170 Itakura Sumi Y., Ogura H., Tanaka H., Koh T., Fujita K., Fujimi S., Nakamori Y., Shimazu T., Sugimoto H. Paradoxical cytoskeleton and microparticle formation changes in monocytes and polymorphonuclear leukocytes in severe systemic inflammatory response syndrome patients. J Trauma 2003; 55(6):1114-32.

171 Jimenez J., Jy W., Mauro L.M., Horstman L.L., Ahn E.R., Ahn Y.S., Minagar A. Elevated endothelial microparticle-monocyte complexes induced by multiple sclerosis plasma and the inhibitory effects of interferon-beta $1 \mathrm{~b}$ on release of endothelial microparticles, formation and transendothelial migration of monocyte-endothelial microparticle complexes. Mult Scler 2005; 11(3):310-5.

172 Minagar A., Jy W., Jimenez J.J., Sheremata W.A., Mauro L.M., Mao W.W., Horstman L.L., Ahn Y.S. Elevated plasma endothelial microparticles in multiple sclerosis. Neurology 2001; 56(10):1319-24.

173 Villmow T., Kemkes-Matthes B., Matzdorff A.C. Markers of platelet activation and platelet-leukocyte interaction in patients with myeloproliferative syndromes. Thromb Res 2002; 108(2-3):139-45.

174 Heloire F., Weill B., Weber S., Batteux F. Aggregates of endothelial microparticles and platelets circulate in peripheral blood. Variations during stable coronary disease and acute myocardial infarction. Thromb Res 2003; 110(4):173-80.

175 Morel O., Jesel L., Hugel B., Douchet M.P., Zupan M., Chauvin M., Freyssinet J.M., Toti F. Protective effects of vitamin $\mathrm{C}$ on endothelium damage and platelet activation during myocardial infarction in patients with sustained generation of circulating microparticles. J Thromb Haemost 2003; 1(1):171-7.

176 Gawaz M., Neumann F.J., Ott I., Schiessler A., Schomig A. Platelet function in acute myocardial infarction treated with direct angioplasty. Circulation 1996; 93(2):229-37.

177 Matsumoto N., Nomura S., Kamihata H., Kimura Y., Iwasaka T. Association of platelet-derived microparticles with C-C chemokines on vascular complication in patients with acute myocardial infarction. Clin Appl Thromb Hemost 2002; 8(3):279-86.

178 Nomura S., Uehata S., Saito S., Osumi K., Ozeki Y., Kimura Y. Enzyme immunoassay detection of platelet-derived microparticles and RANTES in acute coronary syndrome. Thromb Haemost 2003; 89(3):506-12.

179 Simak J., Holada K., Risitano A.M., Zivny J.H., Young N.S., Vostal J.G. Elevated circulating endothelial membrane microparticles in paroxysmal nocturnal haemoglobinuria. Br J Haematol 2004; 114(6):804-13. 
180 Hugel B., Socie G., Vu T., Toti F., Gluckman E., Freyssinet J.M., Scrobohaci M.L. Elevated levels of circulating procoagulant microparticles in patients with paroxysmal nocturnal hemoglobinuria and aplastic anemia. Blood 1999; 93(10):3451-6.

181 Liebman H.A., Feinstein D.I. Thrombosis in patients with paroxysmal noctural hemoglobinuria is associated with markedly elevated plasma levels of leukocyte-derived tissue factor. Thromb Res 2003; 111(4-5):235-8.

182 Zeiger F., Stephan S., Hoheisel G., Pfeiffer D., Ruehlmann C., Koksch M. P-Selectin expression, platelet aggregates, and platelet-derived microparticle formation are increased in peripheral arterial disease. Blood Coagul Fibrinolysis 2000; 11(8):723-8.

183 Van Wijk M.J., Nieuwland R., Boer K., van der Post J.A., Van Bavel E., Sturk A. Microparticle subpopulations are increased in preeclampsia: possible involvement in vascular dysfunction? Am J Obstet Gynecol 2002; 187(2):450-6.

184 Gonzalez-Quintero V.H., Jimenez J.J., Jy W., Mauro L.M., Hortman L., O’Sullivan M.J., Ahn Y. Elevated plasma endothelial microparticles in preeclampsia. Am J Obstet Gynecol 2003; 189(2):58993.

185 Inami N., Nomura S., Kikuchi H., Kajiura T., Yamada K., Nakamori H., Takahashi N., Tsuda N., Hikosaka M., Masaki M., Iwasaka T. P-selectin and platelet-derived microparticles associated with monocyte activation markers in patients with pulmonary embolism. Clin Appl Thromb Hemost 2003; 9(4):309-16.

186 Knijff-Dutmer E.A., Koerts J., Nieuwland R., Kalsbeek-Batenburg E.M., van de Laar M.A. Elevated levels of platelet microparticles are associated with disease activity in rheumatoid arthritis. Arthritis Rheum 2002; 46(6):1498-503.

187 Fujimi S., Ogura H., Tanaka H., Koh T., Hosotsubo H., Nakamori Y., Kuwagata Y., Shimazu T., Sugimoto H. Activated polymorphonuclear leukocytes enhance production of leukocyte microparticles with increased adhesion molecules in patients with sepsis. J Trauma 2002; 52(3):443-8.

188 Joop K., Berckmans R.J., Nieuwland R., Berkhout J., Romijn F.P., Hack C.E., Sturk A. Microparticles from patients with multiple organ dysfunction syndrome and sepsis support coagulation through multiple mechanisms. Thromb Haemost 2001; 85(5):810-20.

189 Nomura S., Kanazawa S., Fukuhara S. Effects of efonidipine on platelet and monocyte activation markers in hypertensive patients with and without type 2 diabetes mellitus. J Hum Hypertens 2002; 16(8):539-47.

190 Preston R.A., Jy W., Jimenez J.J., Mauro L.M., Horstman L.L., Valle M., Aime G., Ahn Y.S. Effects of severe hypertension on endothelial and platelet microparticles. Hypertension 2003; 41(2):211-7.

191 Holme P.A., Orvim U., Hamers M.J., Solum N.O., Brosstad F.R., Barstad R.M., Sakariassen K.S. Shear-induced platelet activation and platelet microparticle formation at blood flow conditions as in arteries with a severe stenosis. Arterioscler Thromb Vasc Biol 1997; 17(4):646-53.

192 Wun T., Paglieroni T., Rangaswami A., Franklin P.H., Welborn J., Cheung A., Tablin F. Platelet activation in patients with sickle cell disease. Br J Haematol 1998; 100(4):741-9.

193 Shet A.S., Aras O., Gupta K., Hass M.J., Rausch D.J., Saba N., Koopmeiners L., Key N.S., Hebbel R.P. Sickle blood contains tissue factor-positive microparticles derived from endothelial cells and monocytes. Blood 2003; 102(7):2678-83.

194 Westerman M.P., Unger L., Kucuk O., Quinn P., Lis L.J. Phase changes in membrane lipids in sickle red cell shed-vesicles and sickle red cells. Am J Hematol 1998; 58(3):177-82.

195 Ogura H., Kawasaki T., Tanaka H., Koh T., Tanaka R., Ozeki Y., Hosotsubo H., Kuwagata Y., Shimazu T., Sugimoto H. Activated platelets enhance microparticle formation and platelet-leukocyte interaction in severe trauma and sepsis. J Trauma 2001; 50(5):801-9.

196 Combes V., Simon A.C., Grau G.E., Arnoux D., Camoin L., Sabatier F., Mutin M., Sanmarco M., Sampol J., Dignat-George F. In vitro generation of endothelial microparticles and possible prothrombotic activity in patients with lupus anticoagulant. J Clin Invest 1999; 104(1):93-102.

197 Abid Hussein M.N., Meesters E.W., Osmanovic N., Romijn F.P., Nieuwland R., Sturk A. Antigenic 
characterization of endothelial cell-derived microparticles and their detection ex vivo. J Thromb Haemost 2003; 1(11):2434-43.

198 Dignat-George F., Camoin-Jau L., Sabatier F., Arnoux D., Anfosso F., Bardin N., Veit V., Combes V., Gentile S., Moal V., Sanmarco M., Sampol J. Endothelial microparticles: a potential contribution to the thrombotic complications of the antiphospholipid syndrome. Thromb Haemost 2004; 91(4):66773.

199 Jimenez J.J., Jy W., Mauro L.M., Horstman L.L., Ahn Y.S. Elevated endothelial microparticles in thrombotic thrombocytopenic purpura: findings from brain and renal microvascular cell culture and patients with active disease. Br J Haematol 2001; 112(1):81-90.

200 Fujimi S., Ogura H., Tanaka H., Koh T., Hosotsubo H., Nakamori Y., Kuwagata Y., Shimazu T., Sugimoto H. Increased production of leukocyte microparticles with enhanced expression of adhesion molecules from activated polymorphonuclear leukocytes in severely injured patients. J Trauma 2003; 54(1):114-9.

201 Vidal C., Spaulding C., Picard F., Schaison F., Melle J., Weber S., Fontenay-Roupie M. Flowcytometry detection of platelet procoagulation activity and microparticles in patients with unstable angina treated by percutaneous coronary angioplasty and stent implantation. Thromb Haemost 2001; 86(3):784-90.

202 Singh N., Gemmell C.H., Daly P.A., Yeo E.L. Elevated platelet-derived microparticle levels during unstable angina. Can J Cardiol 1995; 11(11):1015-21.

203 Nomura S., Uehata S., Saito S., Osumi K., Ozeki Y., Kimura Y. Enzyme immunoassay detection of platelet-derived microparticles and RANTES in acute coronary syndrome. Thromb Haemost 2003; 89(3):506-12.

204 Ando M., Iwata A., Ozeki Y., Tsuchiya K., Akiba T., Nihei H. Circulating platelet-derived microparticles with procoagulant activity may be a potential cause of thrombosis in uremic patients. Kidney Int 2002; 62(5):2527-63.

205 Brogan P.A., Shah V., Brachet C., Harnden A., Mant D., Klein N., Dillon M.J. Endothelial and platelet microparticles in vasculitis of the young. Arthritis Rheum 2004; 50(3):927-36.

206 Myers D.D., Hawley A.E., Farris D.M., Wrobleski S.K., Thanaporn P., Schaub R.G., Wagner D.D., Kumar A., Wakefield T.W. P-selectin and leukocyte microparticles are associated with venous thrombogenesis. J Vasc Surg 2003; 38(5):1075-89.

207 Ahn Y.S., Horstman L.L., Jy W., Jimenez J.J., Bowen B. Vascular dementia in patients with immune thrombocytopenic purpura. Thromb Res 2002; 107(6):337-44.

208 Nomura S., Shouzu A., Nishikawa M., Kokawa T., Yasunaga K. Significance of platelet-derived microparticles in uremia. Nephron 1993; 63(4):485. 


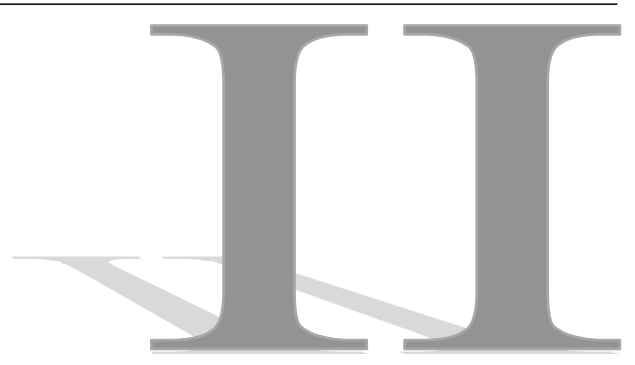

\section{Relationship between intra-uterine bacterial contamination, endotoxin levels and the development of endometritis in postpartum cows with dystocia or retained placenta}

M.J.W. Dohmen, K. Joop, A. Sturk, P.E.J. Bols, J.A.C.M. Lohuis

Contents chapter II

1. Introduction

2. Material and method

2.1 Experimental design

2.2 Collection of lochia, plasma and blood samples

2.3 Endotoxin assay

2.4 Assay for $\mathrm{IgG}$ anti-endotoxin

2.5 Bacteriological examination of uterine swab

2.6 Statistical analysis

3. Results

3.1 Findings immediately postpartum

3.2 Follow-up cows

4. Discussion

5. References 


\begin{abstract}
A study was conducted to investigate the relationship between intra-uterine bacterial contamination, endotoxin levels and the development of endometritis in cows that experienced a dystocia or retained their placenta. Fifteen healthy cows, 31 cows with retained placenta (RP) and 13 cows that had dystocia were clinically examined 1 or 2 days after parturition when a uterine swab for bacteriological examination was taken. In addition, plasma and uterine lochia samples were collected to determine endotoxin and the plasma IgG anti-endotoxin concentrations. Subsequently, 15 RP and 6 dystocia cows were initially left untreated and another uterine swab was collected at 2 and 4 wk postpartum. Immediately after calving, RP cows had significantly higher endotoxin levels in uterine lochia (average of $2.24 \times 10^{4}$ Endotoxin Units $(\mathrm{EU}) / \mathrm{ml}$ ) as compared to dystocia and healthy postpartum cows (average of 0.10 and $0.26 \mathrm{EU} / \mathrm{ml}$, respectively). However, plasma endotoxin levels were below the detection limit $(<0.036 \mathrm{EU} / \mathrm{ml}$ platelet-rich plasma) in all groups of cows. IgG anti-endotoxin levels in plasma were not significantly different between the 3 groups immediately postpartum (average of 26 , 16 and 44 Median Units (MU)/ml for healthy, dystocia and RP cows, respectively), but they were significantly lower when compared to plasma IgG anti-endotoxin levels of healthy cows at more than 2 months postpartum (mean $83 \mathrm{MU} / \mathrm{ml}$ ). High endotoxin levels in lochia at 1 or 2 days postpartum were significantly related to abnormal cervical discharge, the presence of Escherichia coli, black pigmented Gram-negative anaerobes and Clostridium spp. shortly after calving, and Arcanobacterium-pyogenes and Gram-negative anaerobes in the uterus at 14 days postpartum. These results suggest that the presence of E. coli and endotoxin in lochia early postpartum favor the development of uterine infections by A. pyogenes and Gram-negative anaerobes later postpartum. Endotoxin was not observed in plasma, suggesting that either they are not absorbed into the blood, or they are efficiently detoxified by $\operatorname{IgG}$ anti-endotoxin or other detoxification mechanisms.
\end{abstract}




\section{Introduction}

The period immediately after calving is very important in the reproductive lifecycle of a cow because of its vast influence on reproductive efficiency. A normal uterine involution and the re-establishment of the ovarian function postpartum are crucial to obtain the short calving to conception interval that is required to optimize milk and calf production. Peri- or postparturient reproduction disorders most often occur as a complex. Both a difficult calving (dystocia) and the retention of fetal membranes (retained placenta (RP)) have adverse effects on several reproduction parameters and are predisposing factors for the development of uterine infections later postpartum $6,13,14,17,20,23,25$.

As shown by others ${ }^{3,18,20,24}$, intra-uterine infections in RP and dystocia cows are often of a mixed nature. During the first 1 to 2 wk after calving, Gram-negative (G-) facultative anaerobes, such as Escherichia coli, are abundantly present in cows with RP and, to a lesser extent, in cows with a history of dystocia. From 2 wk after calving, the most prominent pathogens present are Arcanobacterium pyogenes (the former Actinomyces pyogenes) and G- anaerobes, such as Bacteroides and Fusobacterium ${ }^{4,8,11}$. The former is generally held responsible for a large part of the decrease in reproductive efficiency due to endometritis. The primary question that arises is which bacteria and virulence factors during the first 1 to $2 \mathrm{wk}$ postpartum in RP and dystocia cows favor the establishment of infections with A. pyogenes later. Therefore, the first objective of this study was to characterize both qualitatively and quantitatively the bacteria present early postpartum in cows with dystocia and RP and relate these findings to the presence of A. pyogenes and signs of sub-acute/-chronic endometritis later postpartum.

Coliform bacteria are abundantly present in lochia of dystocia and RP cows, and endotoxin levels are related proportionally to the numbers of bacteria ${ }^{3,8,9,24,27}$. Previous work in ruminants ${ }^{21,22}$ illustrated that endotoxins are among the most important virulence factors of coliform bacteria that can cause complications in cases of dystocia and RP. Endotoxins can be described as macromolecular complexes of endotoxin, protein and fosfolipids ${ }^{15,16}$. They are very potent inducers of prostaglandin and cytokine release $\mathrm{e}^{21,22,26,27,29}$, and they also play an important role in periparturient diseases ${ }^{21,22,26,27}$. Moreover, endotoxins have direct cytotoxic effects that likely favor the establishment of infections with, for example, A. pyogenes ${ }^{8,11,21,22}$. Therefore, we hypothesize that the development of endometritis later postpartum in dystocia and RP cows is at least partially mediated by coliform bacteria and/or endotoxins early postpartum.

As a second objective we tried to elucidate a possible relationship between bacterial findings and endotoxin concentrations in the uterus of dystocia and RP cows, and a possible relationship between plasma concentrations of endotoxins and $\mathrm{IgG}$ anti-endotoxin, in relation to the development of systemic disease in affected cows. IgG anti-endotoxin is an important factor in the detoxification of endotoxin and thereby a measure for endotoxin exposure. 
A better understanding of the early pathogenesis of uterine infections and subsequent endometritis in cows with dystocia and RP may help in the design of improved measures to prevent uterine infections and also, as a result, fertility disorders.

\section{Material and method}

\subsection{Experimental design}

A total of 59 Holstein dairy cows were used in this study, of which 15 cows had a normal calving without complications (control group), 13 cows had difficulties at calving (dystocia cows), and 31 cows retained their placenta for more than $24 \mathrm{~h}$ (RP cows). The enrolled animals were divided over 23 commercial Dutch dairy farms that had on average 80 dairy cows per farm. All the farms took part in a herd health management program that allowed close monitoring of the data. The mean milk production was about $7200 \mathrm{~kg}$ of milk per cow per year with a mean bulk tank somatic cell count of 178,000 cells $/ \mathrm{ml}$. The mean calving interval was $380 \pm 10 \mathrm{~d}$, and the number of calves each cow had (= parity) was noted, with heifers having parity 1 (after the parturition of the first calf). Cows that had been treated with antibiotics since parturition, or that had a twin delivery, a fetotomy or serious injuries of the birth canal or reproductive tract were not enrolled in the study. All cows were housed under field conditions and were fed commercial concentrated pellets, corn silage and hay.

Within $2 \mathrm{~d}$ after calving, all cows were clinically examined, rectal temperature was taken, and their general condition was noted. Emphasis was put on the appearance of signs of systemic illness. The course of delivery was specified as being 'normal' (hardly assisted by a maximum of one person), 'heavy' (assistance of at least 2 persons needed), and whether or not obstetric actions were necessary or a dead calf was born (stillbirth). The cows were palpated per rectum to check the status of the reproductive tract. The aspect of the cervix and the present vaginal discharge were evaluated during vaginoscopy. In addition, a blood and a lochia sample were taken for endotoxin and IgG anti-endotoxin determination (the latter in plasma only). A uterine swab for bacteriological examination was aseptically collected.

Subsequently, half of the dystocia (6 cows) and RP (15 cows) cows were randomly left untreated, whereas the other half was treated with antibiotics to fulfill a concurrent protocol (data not given). Decision upon treatment was made at random following table random digit numbers ${ }^{30}$. To exclude bias of treatment on the outcome of the clinical and bacteriological findings, the treated cows were not included in the follow up of this study. The 21 untreated cows were further sampled as depicted in Figure 1.

\subsection{Collection of lochia, plasma and blood samples}

Lochia samples were aseptically collected using an empty 50-ml syringe and a sterile disposable catheter. Before sampling, the vulva was carefully washed and disinfected with a nonirritating 


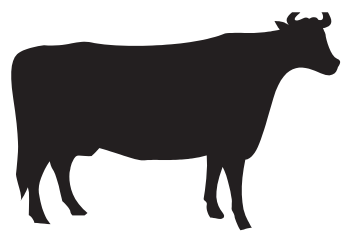

59 Holstein Dairy cows/heifers:

- 15 had normal calving (controls)

-13 had dystocia

-31 retained their placenta $(\mathrm{RP})$
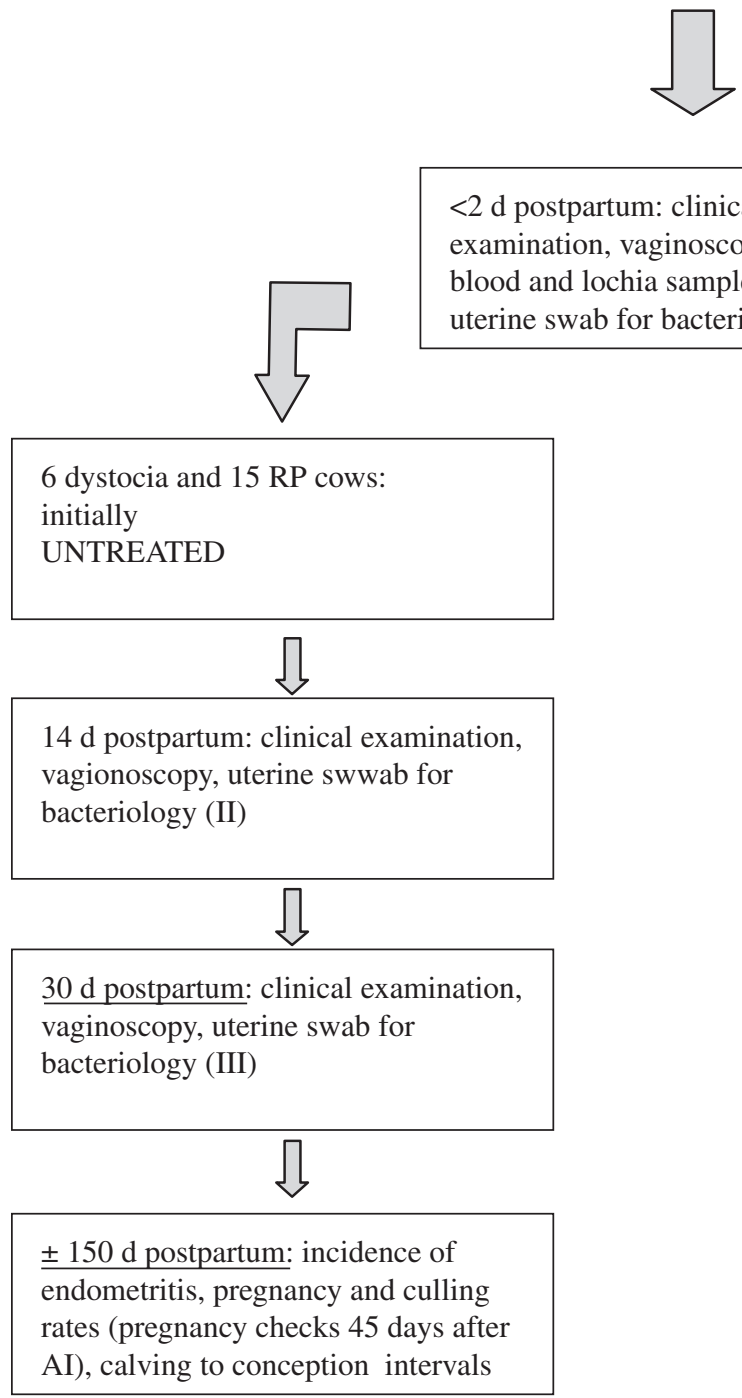

Figure 1. Diagram of the chronology of the sampling events described in the experimental design. 
ethylalcohol solution (Citopogeen ${ }^{\circledR}$ Mycofarm BV, Boxmeer, The Netherlands) and dried. The catheter was carefully inserted in the vagina, avoiding contamination by contact with the vaginal wall. Then it was passed through the cervix into the uterine lumen under rectal guidance by means of the conventional artificial insemination technique. A lochia sample was collected in the catheter by exerting a negative pressure on the syringe after which the sample was transferred immediately into a $6 \mathrm{ml}$ sterile tube $\mathrm{e}^{35}$ and stored on ice. The samples were stored at $-20^{\circ} \mathrm{C}$ within $8 \mathrm{~h}$ after collection, until the endotoxin levels were determined.

Blood samples for endotoxin and IgG anti-endotoxin determinations were collected using $4 \mathrm{ml}$ pyrogen-free heparin containing vacuum tubes (Endotube, Chromogenix AB, Mölndal, Sweden) after the sampling site had been cleaned with $70 \%$ alcohol. A $4 \mathrm{ml}$ blood sample was drawn from the jugular vein using a sterile disposable needle. Blood and heparin were gently mixed and stored on melting ice. Within $8 \mathrm{~h}$, tubes were transported to the laboratory and centrifuged at $540 \mathrm{x}$ g for $10 \mathrm{~min}$ at $4^{\circ} \mathrm{C}$. In preliminary experiments, this centrifugation procedure was found to provide an optimal concentration of trombocytes in the plasma with simultaneous removal of the erythrocytes. Platelet-rich Plasma (PRP) demonstrated to be the material of choice to measure endotoxin concentrations ${ }^{31}$. The plasma was then transferred into 2 pyrogen-free vials with a sterile disposable pipette, avoiding contamination, and stored at $-20^{\circ} \mathrm{C}$ until tested for the presence of endotoxin and $\mathrm{IgG}$ anti-endotoxin.

\subsection{Endotoxin assay}

Lochia and plasma samples were quantitatively tested for the presence of endotoxin using the Limulus Amebocyte Lysate (LAL) test. In this assay, endotoxin activates the coagulation system obtained as a lysate from the amebocyte (i.e., circulating cell) of Limulus polyphemus (the horseshoe crab). The activated coagulation factors can then be measured with a chromogenic substrate. However, in plasma, noncharacterized inhibitory factors of the activation reaction are present. They may include HDL, albumin, anti-endotoxin antibodies, and others. Therefore, plasma samples need to be diluted and heat treated ${ }^{32,33}$. First, the frozen plasma samples were thawed at $37^{\circ} \mathrm{C}$ for $5 \mathrm{~min}$ and stored on ice $(<1 \mathrm{~h})$. Then, they were diluted ten-fold $(\mathrm{v} / \mathrm{v})$ with sterile pyrogenfree water(Chromogenix AB, Mölndal, Sweden) or with pyrogen-free water containing 0.24 Endotoxin Units (EU)/ml endotoxin-standard (= spike). The results were expressed in Endotoxin Units (EU) per milliliter PRP. The potency of the standard expressed in this EU is provided by the manufacturer and is based upon primary standards of purified E. coli endotoxin manufactured by the Federal Drug Administration. The method was validated for bovine plasma with an endotoxin detection limit of $0.036 \mathrm{EU} / \mathrm{ml} \mathrm{PRP}$ (= $0.0036 \mathrm{EU} / \mathrm{ml}$ taken into account the dilution). In addition, endotoxin was added to samples of normal blank human plasma to establish calibration curves. Human plasma was used because this was more readily available at the site of endotoxin testing and because the preliminary experiments with cow plasma indicated that the standard curves were negligibly different. Samples were heat treated at $75^{\circ} \mathrm{C}$ for $15 \mathrm{~min}$ to remove plasma inhibitory activity and then cooled down to room temperature within $\pm 45 \mathrm{~min}$. 
The method for the detection of endotoxin in lochia was slightly different. The frozen lochia samples were thawed as described for plasma. Subsequently, dilutions were performed for lochia samples with very high endotoxin levels. Because of the slimy aspect of the lochia, samples were centrifuged at $2750 \mathrm{x} \mathrm{g}\left(4^{\circ} \mathrm{C}, 10 \mathrm{~min}\right)$. Supernatants were diluted (10-100-1000-10000 times) by adding pyrogen-free water. Several dilutions of each lochia sample were measured, and the lowest dilution giving an extinction that fitted on the calibration curve was used. The results were expressed as Endotoxin Units per milliliter with a detection limit for endotoxin in lochia of $0.036 \mathrm{EU} / \mathrm{ml}$. The standard curves were performed in pyrogen-free water.

The endotoxin assay was performed in microtitre plates, according to the prescriptions of the supplier of the chromogenic assay (Biowhittaker Inc., Walkersville, Maryland, USA). In short, samples were incubated with Limulus Amoebocyte Lysate $\left(37^{\circ} \mathrm{C}, 30 \mathrm{~min}\right)$, and then with substrate $\left(37^{\circ} \mathrm{C}, 6 \mathrm{~min}\right)$. The cascade reaction was stopped by adding $25 \%$ acetic acid. Absorbences were measured at $405 \mathrm{~nm}$ in a microtitre plate reader (Spectra Max 250, Molecular Devices, Sunnyvale, California, USA).

\subsection{Assay for IgG anti-endotoxin}

IgG anti-endotoxin in plasma was assayed by ELISA with endotoxin-precoated microtiter plates and dilution buffer (EndoCab kit, Chromogenix AB, Mölndal, Sweden). Briefly, plasma samples were thawed at room temperature and diluted 200 -fold in the dilution buffer. Then, $100 \mu \mathrm{L}$ of this diluted sample or standards was added to the microtitre plate to allow the anti-endotoxin antibodies in the plasma to bind to the endotoxin on this microtitre plate. After incubation $\left(37^{\circ} \mathrm{C}\right.$, $60 \mathrm{~min}$ ), the plate was washed 3 times with PBS-Tween $0.1 \%$ to remove plasma components that are likely to interfere in the subsequent steps of the assay. Then $100 \mu \mathrm{L}$ of an antibody to bovine IgG was added, which had been conjugated to peroxidase (Kirkegaard \& Perry Laboratories Inc., Gaithersburg, Maryland, USA). After incubation $\left(37^{\circ} \mathrm{C}, 60 \mathrm{~min}\right)$ to allow the anti-bovine $\mathrm{IgG}$ to bind to the $\mathrm{IgG}$ on the microtitre plate, the plate was washed 3 times with PBS-Tween $0.1 \%$ and 5 times with distilled water to remove nonbound anti-bovine IgG. Finally, $100 \mu \mathrm{L}$ of a freshly prepared substrate solution of o-phenylenediamine dihydrochloride $(2.2 \mathrm{mM})$ was added to measure the peroxidase in the complex endotoxin - anti-endotoxin - anti-IgG - peroxidase on the microtitre plate. Incubation was continued for $60 \mathrm{~min}$ at ambient temperature in the dark, after which the reaction was stopped by adding $50 \mu \mathrm{L}$ of $4 \mathrm{~N} \mathrm{H}_{2} \mathrm{SO}_{4}$, and the absorbance was read at $492 \mathrm{~nm}$. EndoCab is expressed in Median Units (MU) (i.e., the median level observed in a group of 100 human volunteers tested by the manufacturer). To get a reference value for healthy cows, plasma samples of 23 healthy lactating non-pregnant cows that were more than 2 month after calving were included in the assay. 


\subsection{Bacteriological examination of uterine swabs}

Uterine swabs for bacteriological examination were collected using a sterile double-sheathed swab apparatus (Nifa Instrumenten B.V., Leeuwarden, The Netherlands). The protected swab was carefully introduced into the uterus, avoiding contamination. Swabs were immediately placed in transport medium (Port-A-Cul, Becton Dickinson B.V., Etten Leur, The Netherlands) and transported to the laboratory at $4{ }^{\circ} \mathrm{C}$ within 1 day after collection. Immediately upon receipt, uterine swabs were resuspended in $2 \mathrm{ml}$ thioglycolic broth that was partly diluted 100 times by adding more broth. Both suspensions were inoculated on 5 different media: aerobic blood agar, Levine-EMB agar (Oxoid Ltd, Basingstoke, Hampshire, UK), anaerobic blood agar, anaerobic blood agar with metronidazole, and FAA agar with vitamin $\mathrm{K}^{3}$ and kanamycin. The blood agar plates contained $5 \%$ sheep blood. Inoculated plates were incubated for 2 to 7 days at $37^{\circ} \mathrm{C}$ in aerobic or anaerobic atmosphere. All colonies that could macroscopically be determined as A. pyogenes, E. coli, F. necrophorum, Bacteroides spp. and/or black pigmented G- anaerobes together with the colonies that were present in $\geqslant 5 \%$ of the total number of colonies were counted and recorded separately. If necessary, these colonies were further identified up to species level, or up to genus level in the case of A. pyogenes, E. coli and F. necrophorum, using appropriate tests (API system). A bacteriological score varying from 0 to 4 was assigned to these bacteria, which corresponded respectively to 'no growth' (Score 0), 0 to 105 Colony Forming Units (CFU) per ml (Score 1), 105 to 106 CFUs per ml (Score 2), 106 to 107 CFUs per ml (Score 3), and 107 to 108 CFUs per ml (Score 4).

\subsection{Statistical analysis}

Collected data were compared between the different groups of cows and statistically analyzed with the Chi-square test and Student's two-sample t-test using the software program Statistix (Statistix ${ }^{\circledast}$ 4.0, Analytical Software, St. Paul, MN, USA).

\section{Results}

\subsection{Findings immediately postpartum}

As shown in Table 1, significantly more heifers were found in the dystocia group (62\%) as compared to the RP group (19\%; P<0.01). At 1 to $2 \mathrm{~d}$ postpartum, rectal temperatures for the $\mathrm{RP}$ cows were significantly increased (average of $39.3^{\circ} \mathrm{C} ; \mathrm{P}<0.05$ ) compared to healthy and dystocia cows. A total of 5 cows ( 4 RP cows, 1 dystocia cow) showed signs of systemic illness.

Lochia of RP cows were abnormal in $29 \%$ of the cases (Table 1), and these cows generally harboured bacteria more frequently and often in a higher number than dystocia and healthy cows (Table 2). In particular, E. coli, G-anaerobes (predominated by black pigmented bacteria) and Clostridium spp. were isolated in a significantly higher frequency in RP cows than in dystocia or healthy cows. The bacteriological score of E. coli was positively correlated with both the number of black-pigmented G-anaerobes $(\mathrm{r}=0.40 ; \mathrm{P}<0.01)$ and the number of Clostridium spp.

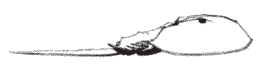


Table 1. Clinical findings in heifers and cows at 1 to 2 days postpartum.

\begin{tabular}{|c|c|c|c|}
\hline & Healthy cows & Dystocia cows & RP cows \\
\hline & $\mathrm{n}=15$ & $\mathrm{n}=13$ & $\mathrm{n}=31$ \\
\hline Parity $($ mean \pm SD) & $2.5 \pm 1.7$ & $1.7 \pm 1.0^{\mathrm{a}}$ & $3.2 \pm 1.9^{\mathrm{b}}$ \\
\hline Percentage of heifers & $27 \%$ & $62 \%{ }^{c}$ & $19 \%{ }^{\mathrm{d}}$ \\
\hline \multicolumn{4}{|l|}{ Course of delivery: } \\
\hline $\operatorname{Normal}(\leq 1$ person $)$ & $100 \%$ & 0 & $78 \%$ \\
\hline Heavy ( $\geq 2$ persons) & 0 & $77 \%$ & $16 \%$ \\
\hline Obstetric actions & 0 & $15 \%$ & $3 \%$ \\
\hline Still birth & 0 & $8 \%$ & $3 \%$ \\
\hline \multicolumn{4}{|c|}{ Percentage of cows with discharge: } \\
\hline Normal & $100 \%{ }^{\mathrm{a}}$ & $92 \%$ & $71 \%{ }^{\mathrm{b}}$ \\
\hline Abnormal* & $0^{\mathrm{a}}$ & $8 \%$ & $29 \%{ }^{\mathrm{b}}$ \\
\hline Foul-smelling discharge & $0^{\mathrm{a}}$ & $0^{\mathrm{a}}$ & $26 \%{ }^{\mathrm{b}}$ \\
\hline Rectal temperature $\left({ }^{\circ} \mathrm{C}\right)$ : & $38.6 \pm 0.3^{\mathrm{a}}$ & $38.8 \pm 0.5^{\mathrm{a}}$ & $39.3 \pm 0.6^{\mathrm{b}}$ \\
\hline
\end{tabular}

* Abnormal discharge is red-brown watery with or without necrotic material.

${ }^{a, b}$ Values in the same row with different superscripts differ $(\mathrm{P}<0.05)$.

${ }^{c, d}$ Values in the same row with different superscripts differ $(\mathrm{P}<0.01)$.

$(\mathrm{r}=0.44 ; \mathrm{P}<0.001)$. The bacteriological score of black-pigmented G-anaerobes was positively correlated with the bacteriological score of $\mathrm{A}$. pyogenes $(\mathrm{r}=0.60 ; \mathrm{P}<0.001)$.

Although variation in endotoxin levels in lochia within the groups was large, levels were significantly $(\mathrm{P}<0.05)$ higher in the RP group $\left(2.24 \times 10^{4} \pm 4.94 \times 10^{4} \mathrm{EU} / \mathrm{ml}\right)$ compared to the healthy and dystocia groups (maximum levels of respectively 2 and $0.6 \mathrm{EU}$ endotoxin per $\mathrm{ml}$; see Figure 2).

Table 2. Frequency rate (freq.) and mean bacteriological score (score) of uterus isolates in healthy, dystocia and retained placenta (RP) cows at 1 to 2 days postpartum.

\begin{tabular}{lllllll} 
& \multicolumn{2}{l}{ Healthy cows } & \multicolumn{2}{l}{ Dystocia cows } & \multicolumn{2}{l}{ RP cows } \\
& $\mathrm{n}=15$ & $\mathrm{n}=13$ & $\mathrm{n}=31$ & & \\
\hline & freq. & score & freq. & score & freq. & score \\
\hline A. pyogenes & $7 \%$ & 1.0 & 0 & - & $10 \%$ & 3.0 \\
E. coli & $33 \%^{\mathrm{a}}$ & 2.6 & $38 \%^{\mathrm{a}}$ & $1.2^{\mathrm{a}}$ & $97 \%^{\mathrm{b}}$ & $3.1^{\mathrm{b}}$ \\
Coliforms (no E. Coli) & $27 \%$ & 1.3 & $8 \%$ & 1.0 & $13 \%$ & 2.5 \\
Streptococci & 0 & - & $8 \%$ & 1.0 & $6 \%$ & 2.0 \\
Staphylococci & 0 & - & $8 \%$ & 4.0 & $3 \%$ & 3.0 \\
Black pigmented anaerobes & $13 \% \%^{\mathrm{c}}$ & 1.5 & $0 \%^{\mathrm{c}}$ & - & $45 \%{ }^{\mathrm{d}}$ & 2.1 \\
Bacteroides spp. & 0 & - & $8 \%$ & 1.0 & $20 \%$ & - \\
F. necrophorum & $7 \%$ & 1.0 & 0 & - & $3 \%$ & 3.0 \\
Clostridium spp. & $7 \%^{\mathrm{a}}$ & 4.0 & $8 \% \%^{\mathrm{a}}$ & 1.0 & $65 \%$ & 3.0 \\
\hline
\end{tabular}

a,b Values in the same row with different superscripts differ $(\mathrm{P}<0.001)$.

${ }^{\mathrm{c}, \mathrm{d}}$ Values in the same row with different superscripts differ $(\mathrm{P}<0.05)$. 


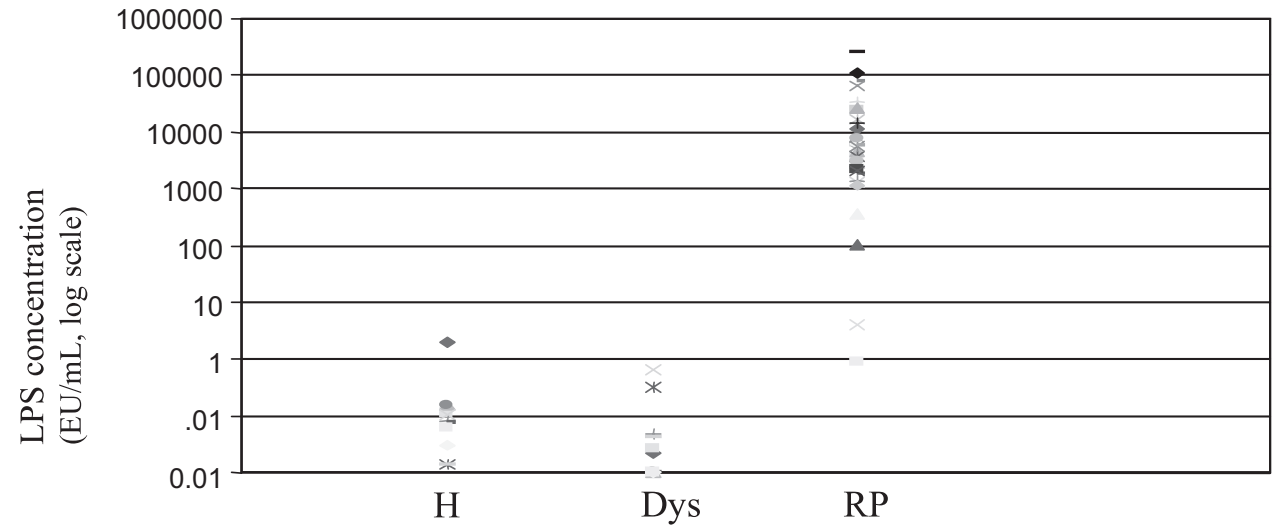

Figure 2. Individual endotoxin levels in lochia (logarithmic scale) at 1 or 2 days postpartum in healty (H, $\mathrm{n}=11$ ), dystocia (Dys, $\mathrm{n}=11$ ) and retained placenta $(\mathrm{RP}, \mathrm{n}=31)$ cows. Average values between healty and dystocia cows, and RP cows differ significantly $(\mathrm{P}<0.05)$.

Despite the high endotoxin levels in lochia of RP cows, endotoxin concentrations in plasma were below the detection limit $(<0.036 \mathrm{EU} / \mathrm{ml})$ in all cows. No significant differences $(\mathrm{P}>0.05)$ between the different groups of postpartum cows were observed for the IgG antiendotoxin levels in plasma. However, IgG anti-endotoxin levels in plasma of cows at 1 to 2 days postpartum were significantly lower $(\mathrm{P}<0.05)$ than $\mathrm{IgG}$ anti-endotoxin plasma levels of healthy cows later postpartum (Figure 3).

Higher endotoxin concentrations in lochia were found to be positively correlated with the presence of abnormal and foul-smelling discharge, the rectal temperature, and especially the presence of E.coli, black pigmented G-anaerobes and Clostridium spp $(\mathrm{P}<0.05)$. The

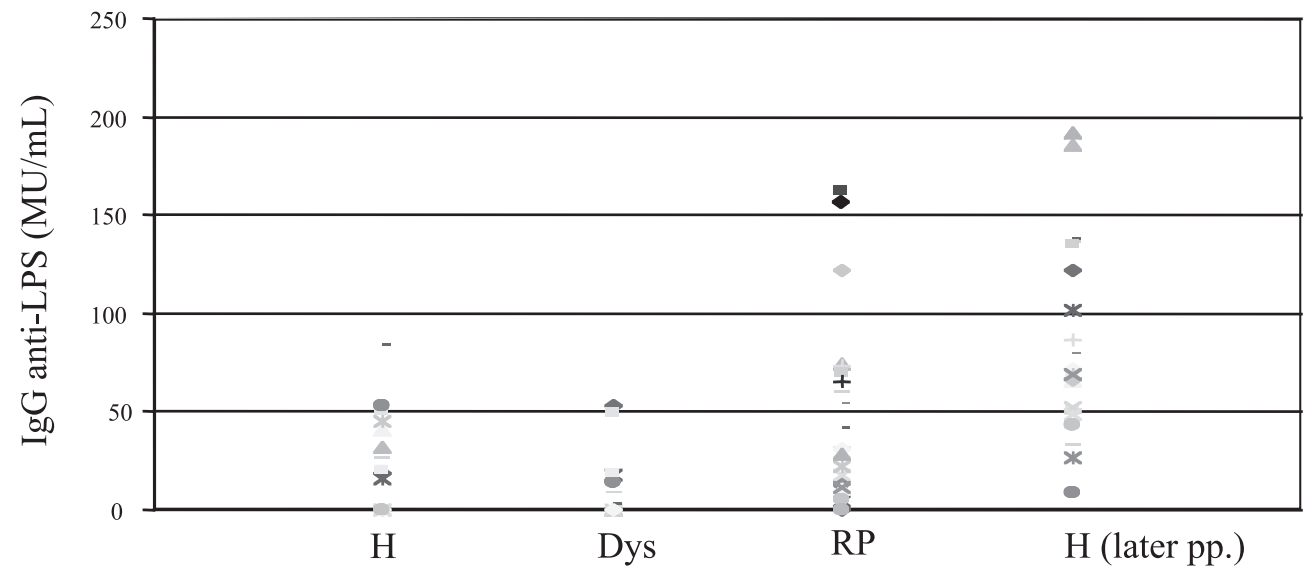

Figure 3. Individual IgG anti-LPS levels in plasma at 1 to 2 days postpartum in healthy $(\mathrm{H}, \mathrm{n}=15)$, dystocia (Dys, $n=11$ ), retained placenta $(R P, n=30)$ and healthy cows later postpartum (H (later pp), $n=23$ ). Average values between healthy, distocia and RP cows and healthy cows later postpartum differ significantly $(\mathrm{P}<0.05)$. 
bacteriological score of $\mathrm{E}$. coli was also positively correlated with the endotoxin levels $(\mathrm{r}=0.35$; $\mathrm{P}<0.05)$. Parity did affect not endotoxin and $\mathrm{IgG}$ anti-endotoxin levels.

\subsection{Follow-up cows}

The 6 dystocia and 15 RP cows randomly left untreated immediately after calving were subsequently part of a follow-up study up to 150 days postpartum. The isolation frequencies of A. pyogenes, E. coli and black pigmented anaerobes from these cows are given in Table 3. After an increase at $14 \mathrm{~d}$ postpartum, prevalence rates of all bacteria for both dystocia and RP cows had decreased at 30 days postpartum. Streptococci and staphylococci were hardly isolated at 14 and 30 days postpartum (data not given, maximum 1 cow infected per group per time point).

At 14 d postpartum, abnormal discharge (i.e., (muco)purulent) was observed in $33 \%$ of the dystocia group and $92 \%$ of the RP group. At $30 \mathrm{~d}$ postpartum, all cows except one had normal discharge. In total, 8 of the 21 cows had been treated because of endometritis: 4 RP cows already in the first week postpartum, and the other 4 between 14 and $33 \mathrm{~d}$ after calving (Table 3). At $150 \mathrm{~d}$ after parturition, 4 out of 15 RP cows had been culled. Four out of 6 dystocia cows (67\%) and 6 out of 11 RP cows (55\%) were pregnant after on average 1.8 and 1.2 inseminations per cow, respectively. The average calving to conception intervals were 78 days for the dystocia and 94 days for the RP cows.

Presence of abnormal cervical discharge at 1,14 and $28 \mathrm{~d}$ postpartum was positively related to the presence of $\mathrm{A}$. pyogenes $(\mathrm{P}<0.05)$ and, except for day 1 postpartum, also with $\mathrm{G}$-anaerobes $(\mathrm{P}<0.05)$. The presence of $\mathrm{E}$. coli was not related to the aspect of the discharge $(\mathrm{P}>0.1)$. However, a positive relationship between the presence of $\mathrm{E}$. coli at 1 day postpartum and the presence of $\mathrm{A}$. pyogenes and $\mathrm{G}$-anaerobes at $14 \mathrm{~d}$ postpartum was found (Figure 4, $\mathrm{P}<0.05$ ). An even stronger relation was present between endotoxin levels in lochia of 1 day postpartum and the presence of both $\mathrm{A}$. pyogenes and $\mathrm{G}$-anaerobe bacteria at $14 \mathrm{~d}$ postpartum $(\mathrm{P}<0.01)$. No significant relationships between endotoxin levels and bacteriological data at $30 \mathrm{~d}$ postpartum were observed, possibly because the number of available cases at this time had decreased due to treatments.

Table 3. Frequency rates (\%) of uterus isolates at 14 and 30 days postpartum in untreated cows.

\begin{tabular}{lllll}
\hline & \multicolumn{2}{l}{ Dystocia cows (n=6) } & \multicolumn{2}{l}{ RP cows (n=15) } \\
& $14 \mathrm{~d} \mathrm{pp}$ & $30 \mathrm{~d} \mathrm{pp}$ & $14 \mathrm{~d} \mathrm{pp}$ & $30 \mathrm{~d}$ pp \\
\hline Treated for endometritis $^{1}$ & $0 \%$ & $17 \%$ & $27 \%$ & $40 \%$ \\
A. pyogenes & $40 \%$ & $0 \%$ & $89 \%$ & $29 \%$ \\
E. coli & $60 \%$ & $33 \%$ & $44 \%$ & $11 \%$ \\
Black pigmented anaerobes & $0 \%$ & $0 \%$ & $44 \%$ & $14 \%$ \\
Bacteroides spp. & $0 \%$ & $0 \%$ & $56 \%$ & $17 \%$ \\
F. necrophorum & $0 \%$ & $0 \%$ & $33 \%$ & $0 \%$ \\
Clostridium spp. & $0 \%$ & $0 \%$ & $11 \%$ & $0 \%$ \\
\hline
\end{tabular}

${ }^{1}$ Cows which had been treated in the mean time for endometritis. No additional uterine swabs of these cows were collected. $\mathrm{pp}=$ postpartum 


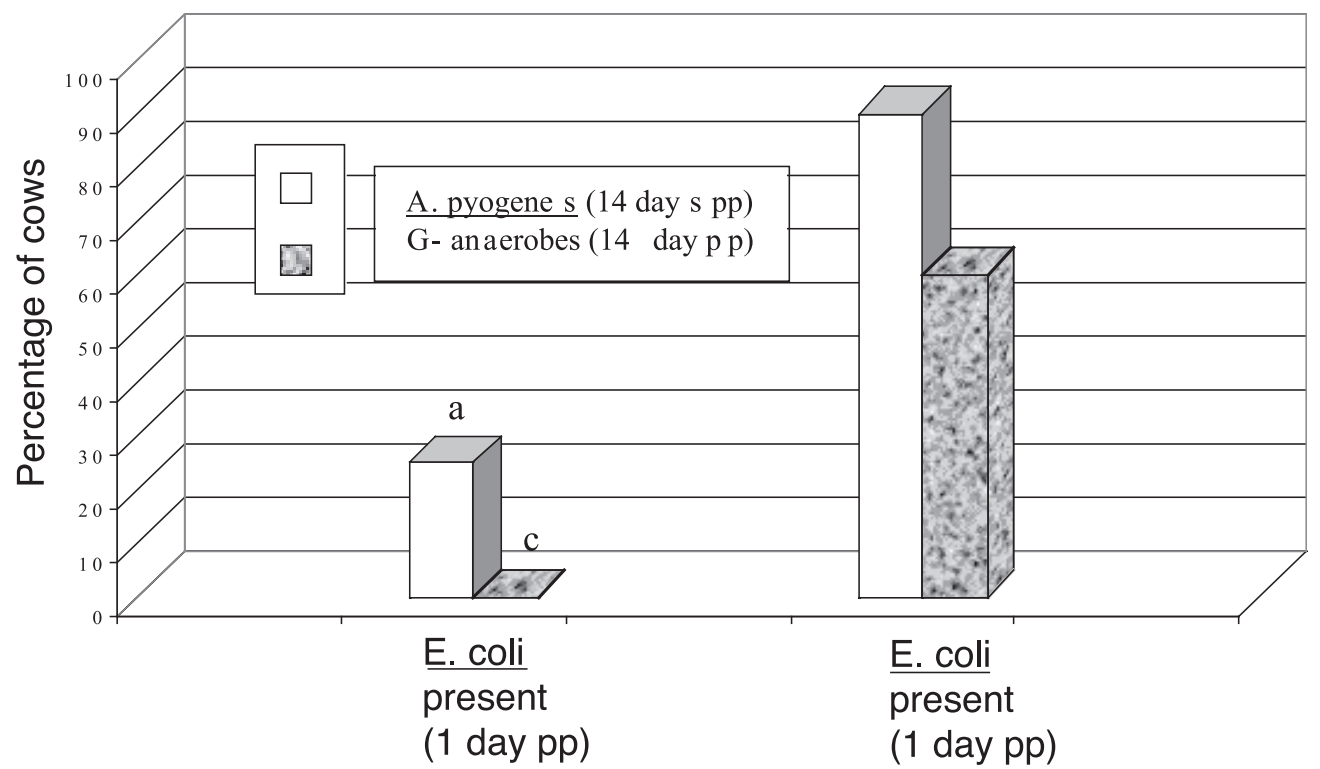

Figure 4. Relationship between the precence of E. coli at 1 day postpartum (pp) and the prevalance of A pyogenes and $\mathrm{G}$-anaerobes at 14 days $\mathrm{pp}^{\text {abcd. }}$. Values with different superscripts differ significantly $(\mathrm{P}<0.05)$.

\section{Discussion}

Having studied qualitative and quantitative aspects of intra-uterine bacterial contamination, we could not only confirm previous reports; $8 ; 24$ on this topic, but also demonstrate some valuable interrelationships on the appearance of certain pathogens and endotoxins in the course of the development of endometritis in cows that had dystocia or RP. Our findings show that immediately after calving, RP cows were more often infected with various bacteria like E. coli, Clostridum spp. and G-anaerobes (prevalence rates up to 97\%) than cows without periparturient disorders. Results also confirm that E. coli is mainly present during the first days postpartum, whereas A. pyogenes and G-anaerobes are present in the uterus for a longer period ${ }^{7 ; 8 ; 24}$. Our results allow us to show a positive relationship between the presence of E. coli and endotoxins in the uterus at 1 to $2 \mathrm{~d}$ postpartum and the presence of A. pyogenes and G-bacteria at $14 \mathrm{~d}$ postpartum. This suggests that the bacterial contamination present in the uterus shortly after parturition favors the development of uterine infections by A. pyogenes and G-anaerobes later postpartum. As a consequence, advice on optimal calving conditions and hygiene around parturition can be substantiated.

Although acute endometritis is known to be related to high endotoxin levels (Intervet data, on file) and the presence of both A. pyogenes and G- bacteria in the uterus ${ }^{9 ; 28}$, little is known about their role in the establishment of uterine infections later postpartum except that they act

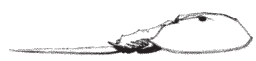


synergistically, causing a significant negative effect on reproduction ${ }^{1 ; 4 ; 8 ; 11}$. Because they lack the ability to invade intact epithelium, these are usually considered facultative pathogens and therefore require a damaged epithelium to establish infection ${ }^{19}$, which can be the case shortly after a dystocia. Later postpartum, an E. coli infection was needed to damage the endometrium, enabling absorption of endotoxins ${ }^{12 ; 27}$. Although the variation within the group was large, RP cows had significantly higher endotoxin levels in uterine lochia shortly after calving compared to dystocia and healthy postpartum cows. Despite these high endotoxin levels and a significant increase in body temperature, only 5 cows were systemically ill at the time of sampling. Moreover, these sick cows did not have the highest endotoxin concentrations in their lochia. Endotoxin levels in plasma on the other hand were below the detection limit in all groups of cows, suggesting that either they are not absorbed into the blood, which is contradicted by the work of Peter et al. ${ }^{27}$ and Gilbert et al. ${ }^{12}$, or they are sufficiently detoxified by IgG anti-endotoxin or other detoxification mechanisms such as the acyloxyacyl hydrolase (AOAH) system ${ }^{10}$. This can explain why some cows get sick and others do not, depending on the normal function of their detoxification mechanisms.

An important mechanism to detoxify endotoxin is the IgG anti-endotoxin system. According to Barclay ${ }^{2}$, the IgG anti-endotoxin levels steadily increase in humans until they stabilize at the adult median around the age of $7 \mathrm{yr}$. We found no relationship between parity and $\mathrm{IgG}$ anti-endotoxin, suggesting that $\mathrm{IgG}$ anti-endotoxin levels in cows reach the maximum range within $1 \mathrm{yr}$. In the case of endotoxemia, IgG anti-endotoxin levels generally fall, but will soon be recovered from a reservoir that is present in the interstitial fluid ${ }^{2}$. This was partly confirmed by Troedsson et al. ${ }^{34}$, who saw a drop in the concentration of total IgG during the first $24 \mathrm{~h}$ after an intra-uterine challenge infection with Streptococcus zooepidemicus in mares. However, between 24 and $36 \mathrm{~h}$ after infection, the total IgG levels in resistant mares were re-established at the baseline levels, suggesting that these mares cleared the infection within $24 \mathrm{~h}$, after which IgG was not needed anymore to opsonize residual bacteria. In contrast, IgG levels in susceptible mares continued to decline. Despite the high endotoxin levels found in lochia, IgG anti-endotoxin levels in the plasma of RP cows were not significantly different from the IgG anti-endotoxin levels in the other groups of cows immediately postpartum. Striking however are the significantly lower IgG anti-endotoxin levels in all groups of cows shortly after parturition when compared to healthy cows later postpartum. This decrease in IgG anti-endotoxin levels can possibly be caused by their binding to endotoxin that seep from the uterine lumen into the systemic circulation through a damaged endometrium. Consequently, the decline in the IgG anti-endotoxin levels can be seen as an indirect measure for the amount of endotoxins involved. Brenner and colleagues ${ }^{5}$ saw a drop of about $25 \%$ in the total serum IgG levels of healthy cows when comparing levels measured at 7 to $11 \mathrm{~d}$ before parturition with those measured at parturition. The decline in IgG anti-endotoxin levels could therefore be caused by the decline in the total $\mathrm{IgG}$ concentration. Brenner et al. ${ }^{5}$ hypothesized that $\mathrm{IgG}$ is transferred to the colostrum at the start of lactation, explaining the low concentrations in all postpartum cows. Additional 
differential analysis of both $\operatorname{IgG}$ anti-endotoxin and total $\mathrm{IgG}$ levels is needed to elucidate the cause of this marked decline.

The main conclusion of our study is that the presence of large numbers of E. coli and high concentrations of endotoxin/endotoxins in lochia of dystocia and RP cows shortly after parturition favor the development of uterine infections by A. pyogenes and G- anaerobes later postpartum. Despite the high endotoxin levels in lochia, no endotoxin was detected in the plasma of healthy, dystocia or RP cows. The normal function of the uterine wall and the detoxification mechanisms will determine whether the cow will show signs of systemic illness. Results of this study indicate that measures to prevent and treat intra-uterine infections with E. coli in the immediate postpartum period may aid in reducing endometritis later. 


\section{References}

1. Ball L., Olson J.D., Mortimer R.G. Therapeutic considerations for the postpartum bovine uterus. Soc Theriogenology Newsl 1984; 7:4-5.

2. Barclay G.R. Endogenous endotoxin-core antibody (EndoCab) as a marker of endotoxin exposure and a prognostic indicator: a review. Bacterial Endotoxins: Lipopolysaccharides from genes to therapy 1995; Wiley-Liss Inc;263-272.

3. Bekana M., Jonsson P., Ekman T., Kindahl H. Intrauterine bacterial findings in postpartum cows with retained fetal membranes. J Vet Med A 1994; 41:663-670.

4. Bonnett B.N., Martin S.W., Gannon V.P.J., Miller R.B., Etherington W.G. Endometrial biopsy in Holstein-Friesian dairy cows. III. Bacteriological analysis and correlations with pathological findings. Can J Vet Res 1991; 55:168-173.

5. Brenner J., Shemesh M., Shore L.S., Friedman S., Bider Z., Moalem U., Trainin Z. A possible linkage between gonadal hormones, serum and uterine levels of $\mathrm{IgG}$ of dairy cows. Vet Immunol Immunop 1995; 47:179-184.

6. Correa M.T., Erb H., Scarlett J. Path analysis for seven postpartum disorders of holstein cows. J Dairy Sci 1993; 76:1305-1312.

7. Dobson D.P., Noakes D.E. Use of a uterine pessary to prevent infection of the uterus of the cow after parturition. Vet Rec 1990; 127:128-131.

8. Dohmen M.J.W., Lohuis J.A.C.M., Huszenicza G.Y., Nagy P., Gacs M. The relationship between bacteriological and clinical findings in cows with subacute/chronic endometritis. Theriogenology 1995; 43:1379-1388.

9. Dohmen M.J.W., Huszenicza G.Y., Fodor M., Kulcsár M., Vámos M., Porkoláb L., Szilágyi N., Lohuis J.A.C.M. Bacteriology and fertility in healthy postpartum cows and cows with acute endometritis. Proc XIX World Buiatrics Congress 1996; 238-241.

10. Dosogne H., Burvenich C., Lohuis J.A.C.M. Acyloxyacyl hydrolase activity of neutrophil leukocytes in normal early postpartum dairy cows and in cows with retained placenta. Theriogenology 1999; 51:869874.

11. Farin P.W., Ball L., Olson J.D., Mortimer R.G., Jones R.L., Adney W.S., McChesney A.E. Effect of Actinomyces pyogenes and gram-negative anaerobic bacteria on the development of bovine pyometra. Theriogenology 1989; 31:979-989.

12. Gilbert R.O., Bosu W.T.K., Peter A.T. The effect of Escherichia coli endotoxin on luteal function in Holstein heifers. Theriogenology 1990; 33:645-651.

13. Grön Y.T., Erb H.N., McCulloch C.E., Saloniemi H.S. Epidemiology of reproductive disorders in dairy cattle: associations among host characteristics, disease and production. Prev Vet Med 1990; 8:25-39.

14. Halpern N.E., Erb H.N., Smith R.D. Duration of retained fetal membranes and subsequent fertility in dairy cows. Theriogenology 1985; 23:807-813.

15. Henderson B., Poole S., Wilson M. Bacterial modulins: a novel class of virulence factors which cause host tissue pathology by inducing cytokine synthesis. Microbiol Rev 1996; 60:316-341.

16. Henderson B., Wilson M. Cytokine induction by bacteria: beyond lipopolysaccharide. Cytokine 1996; 4:269-282.

17. Kaneene J.B., Miller R. Risk factors for metritis in Michigan dairy cattle using herd- and cow-based modelling approaches. Prev Vet Med 1995; 23:183-200.

18. Kaneko K., Kawakami S., Miyoshi M., Abukawa T., Yamanaka S., Mochizuki M., Yoshihara S. Effect of retained placenta on subsequent bacteriological and cytological intrauterine environment and production in Holstein dairy cows. Theriogenology 1997; 48:617-624.

19. Kasari T.R., Marquis H., Scanlan C.M. Septic arthritis and osteomyelitis in a bovine digit: a mixed infection of Actinomyces pyogenes and Fusobacterium necrophorum. Cornell Vet 1988; 78:215-219.

20. Laven R.A., Peters A.R. Bovine retained placenta: aetiology, pathogenesis and economic loss. Vet Rec 1996; 139:465-471. 
21. Lohuis J.A.C.M., Verheijden J.H.M., Burvenich C., van Miert A.S.J.P.A.M. Pathophysiological effects of endotoxins in ruminants. 1. Changes in body temperature and reticulo-rumen motility, and the effect of repeated administration. Vet Quart 1988; 10:109-116.

22. Lohuis J.A.C.M., Verheijden J.H.M., Burvenich C., van Miert A.S.J.P.A.M. Pathophysiological effects of endotoxins in ruminants. 2. Metabolic aspects. Vet Quart 1988; 10:117-125.

23. Mellado M., Reyes C. Associations between periparturient disorders and reproductive efficiency in Holstein cows in northern Mexico. Prev Vet Med 1994; 19:203-212.

24. Olson J.D., Ball L., Mortimer R.G., Farin P.W., Adney W.S., Huffman E.M. Aspects of bacteriology and endocrinology of cows with pyometra and retained fetal membranes. Am J Vet Res 1984; 45:22512255.

25. Paisley L.G., Mickelsen W.D., Anderson P.B. Mechanisms and therapy for retained fetal membranes and uterine infections of cows: a review. Theriogenology 1986; 25:353-381.

26. Peter A.T., Bosu W.T.K. Effects of intrauterine infection on the function of the corpora lutea formed after first postpartum ovulations in dairy cows. Theriogenology 1987; 27:593-609.

27. Peter A.T., Bosu W.T.K., Gilbert R.O. Absorption of Escherichia coli endotoxin (lipopolysaccharide) from the uteri of postpartum dairy cows. Theriogenology 1990; 33:1011-1014.

28. Scholten D., Nieuwenhuis H.U.R., Gunnink J.W., Werdler M.E.B., Zee-Kotting van de W.I. Acute puerperale endometritis bij het rund. Vet Rec (Dutch Edition) 1992; 6:88-91.

29. Slama H., Vaillancourt D., Goff A.K. Effect of bacterial cell wall and lipopolysaccharide on arachidonic acid metabolism by caruncular and allantochorionic tissues from cows that calved normally and those that retained fetal membranes. Theriogenology 1994; 41:923-941.

30. Snedecor G.W., Cochran W.G. Statistical Methods. 7th Edition, Iowa State University press 1982: 463466.

31. Steverink P.J.G.M., Sturk A., Salden H.J.M. Platelet-Poor Plasma not suitable for clinical endotoxin testing, demonstrated in horses. Clin Chem 1994; 40:1346-1347.

32. Sturk A., Joop K., ten Cate J.W., Thomas L.L.M. Optimalization of a chromogenic assay for endotoxin in blood. In: 'Bacterial endotoxins: structure, biomedical significance, and detection with the Limulus Amebocyte Lysate test.' 1985; Alan R Liss Inc New York: 371-385.

33. Sturk A., Janssen M.E., Muylaert F.R., Joop K., Thomas L.L.M., ten Cate J.W. Endotoxin testing in blood. In: Detection of bacterial endotoxins with the Limulus Amebocyte Lysate test. 1987; Alan R Liss Inc, New York: 371-385.

34. Troedsson M.H.T., Liu I.K.M., Thurmond M. Immunoglobulin (IgG and IgA) and complement (C3) concentrations in uterine secretion following an intrauterine challenge of Streptococcus zooepidemicus in mares susceptible to versus resistant to chronic uterine infection. Biol Reprod 1993; 49:502-506.

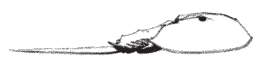




\section{CHAPTER}

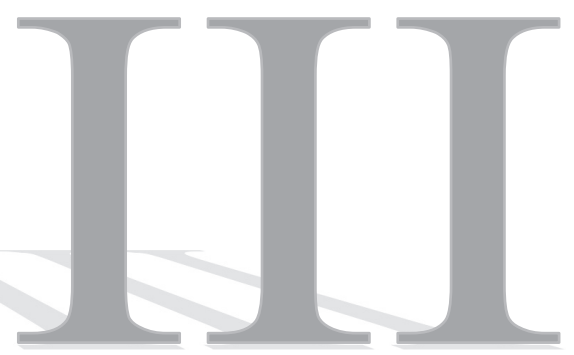

Relationship between gastrointestinal complains and endotoxemia, cytokine release and the acute-phase reaction during and after a long-distance triathlon in highly trained men

A.E. Jeukendrup, K. Joop, A. Sturk, J.H.J.C. Stegen, J. Senden, W.H.M. Saris,

A.J.M. Wagenmakers

\section{Contents chapter III}

1. Introduction ...

2. Methods

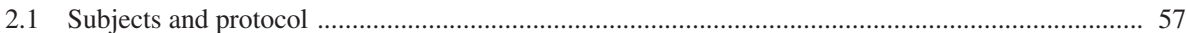

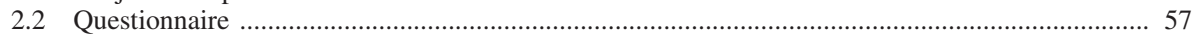

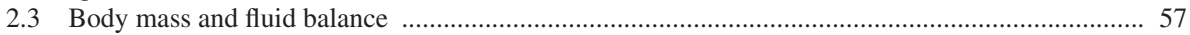

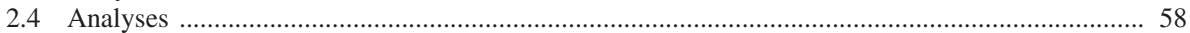

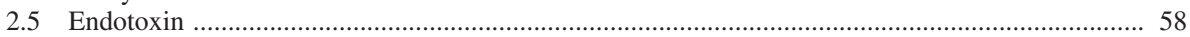

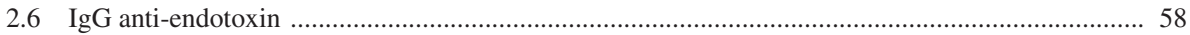

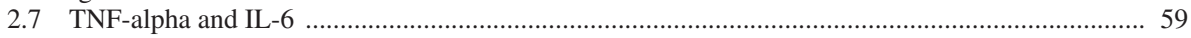

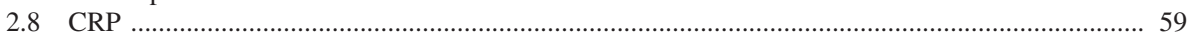

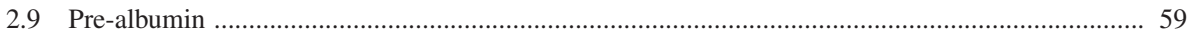

2.10 CK

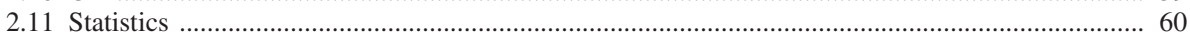

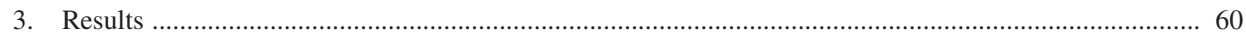

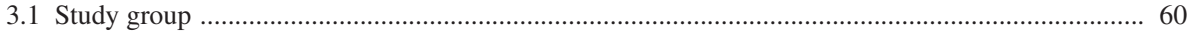

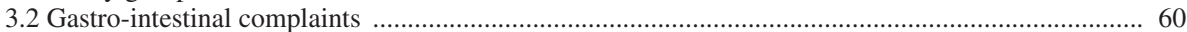

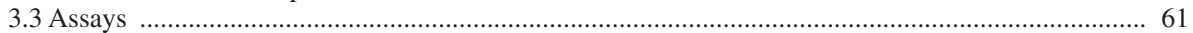

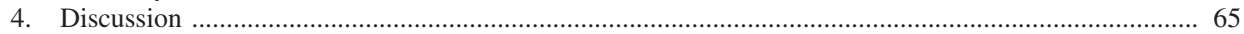

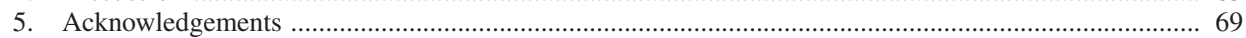

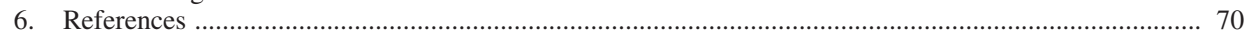




\begin{abstract}
The aim of the present study was to establish whether the gastro-intestinal (GI) complaints observed during and after ultra-endurance exercise are related to gut ischemia-associated leakage of endotoxins into the circulation and associated cytokine production.
\end{abstract}

Therefore we collected blood samples from 29 athletes before, immediately after, and 1, 2 and 16 hours after a long-distance triathlon for measurements of endotoxin, tumour necrosis factor (TNF-alpha and interleukin-6 (IL-6). As the cytokine response would trigger an acute phase response, characteristic variables of these responses were also measured as well as creatine kinase $(\mathrm{CK})$ to obtain an indicator of muscle damage.

There was a high incidence (93\% of all participants) of gastro-intestinal (GI) symptoms, $45 \%$ even reported severe complaints and $7 \%$ of the participants abandoned the race because of severe GI-distress. 68\% Of the athletes had mild endotoxemia $(5-15 \mathrm{pg} / \mathrm{ml})$ immediately post-race, as also indicated by a reduction in IgG anti-endotoxin antibody levels. In addition, we observed a production of IL-6 (27 fold increase immediately after the race), leading to an acute phase response (20-fold increase in CRP and 12\% decrease of pre-albumin 16 hours after the race). However, the extent of endotoxemia was not correlated to the GI-complaints.

It is therefore concluded that endotoxin does enter the circulation after ultra-endurance exercise but in view of the absence of a correlation between the extent of endotoxemia and GI-complaints, this endotoxin leakage does not seem to be responsible for the observed GIproblems in these athletes. 


\section{Introduction}

Prolonged exercise at high intensities leads to a quantitative redistribution of blood flow. The blood flow to the exercising muscle is increased (exercise hyperaemia) in proportion to the energy demand in order to increase the supply of oxygen and substrates. In addition, during intense exercise the blood flow to the skin is increased to facilitate heat dissipation. As a consequence the blood flow to central tissues (gut and liver) is reduced during exercise ${ }^{1 ; 2}$. Clausen $^{3}$ reported that during maximal exercise in man blood flow to the gut is reduced by about $80 \%$. Exercise in the heat leads to an extra loss of total body water and a greater reduction in plasma volume. The blood flow to the gut may even be further reduced during such extreme conditions $\mathrm{s}^{4 ; 5}$. A similar redistribution of blood flow is seen in patients with major trauma and/ or sepsis and various forms of shock $^{6}$. In this situation a serious under perfusion of the gut often leads to shock-induced mucosal damage and invasion of gram-negative intestinal bacteria and/ or their toxic constituents (endotoxins) into the blood circulation ${ }^{7}$. Endotoxins are highly toxic that form part of the outer cell wall of gram-negative bacteria. The shock-induced damage to gut mucosa is probably mediated by an excess production of oxygen-derived free radicals in the reperfusion stage following ischaemia ${ }^{8 ; 9}$. Increased circulating endotoxin levels in patients lead to various symptoms such as fever, shivering, dizziness, nausea, various gastro-intestinal complaints such as vomiting and diarrhea, and ultimately sepsis ${ }^{10}$. Similar symptoms may be found in athletes involved in ultra-endurance exercise in combination with heat stress and dehydration.

There is a very high prevalence of gastro-intestinal complaints during exercise among longdistance runners and athletes involved in other types of strenuous long lasting exercise ${ }^{11-13}$. These symptoms include high body temperature, dizziness, nausea, and vomiting and are very similar to the symptoms seen in patients with systemic endotoxemia. In addition, ultra-endurance athletes often report gastro-intestinal problems like stomach cramps or stomachache, intestinal cramps and diarrhea. Prevalences of 30-50\% have been reported among marathon runners ${ }^{14-16}$. Marathon runners occasionally develop serious gut complaints (blood loss in faeces) in the hours following a marathon. Schaub et al. ${ }^{17}$ observed epithelial surface changes known to occur during ischemia upon colonoscopic inspection of one such athlete following a marathon and suggested that ischemia of the lower gastrointestinal tract induced the problems. Øktedalen et al. ${ }^{18}$ reported increased intestinal permeability after a marathon. Despite the high prevalence, the etiology of these gastro-intestinal complaints in endurance athletes is still incompletely understood.

As discussed above, decreased splanchnic blood flow may lead to ischemic damage to the intestinal wall. In addition, during intense exercise under extreme conditions mucosal damage may also be caused by thermal and mechanical damage to the mucosal layer of the gut and thus to a partial loss of the immunological barrier function of the gut. If this is the case, gramnegative bacteria, present in the gut, may penetrate the mucosal layer and enter the lymph nodes 
in the sub mucosal tissues. This may lead to the entrance of endotoxin in the portal vein and under extreme conditions maybe even in the main circulation (as observed in shock patients). Indeed, endotoxemia after strenuous ultra-endurance exercise has been reported. Brock-Utne et al. ${ }^{19}$ reported that $81 \%$ of 89 ultra-marathon runners in the Comrades marathon $(90 \mathrm{~km})$ demonstrated elevated plasma endotoxin concentrations. Two percent showed endotoxin concentrations above $1.0 \mathrm{ng} / \mathrm{ml}$, a value reported in patients with meningococcal sepsis and considered to be extremely high if one considers a value of $5 \mathrm{pg} / \mathrm{ml}$ the limit for endotoxemia to predict or exclude oncoming sepsis ${ }^{20}$. However, in that study, resting levels of endotoxin also were in the range usually observed in critically-ill septic patients. In another study endotoxin concentrations increased and the anti-endotoxin IgG levels markedly decreased after a triathlon (3.2 km swim, $140 \mathrm{~km}$ cycling, $42.2 \mathrm{~km}$ run) ${ }^{21}$. Again, the reported resting levels of endotoxin were in the range usually observed in critically ill septic patients, which raise doubt about the validity of those results. Studies in race horses after short distance $1000-2800 \mathrm{~m} \mathrm{races}^{22}$, cyclists with post-exertional illness after a 100 mile ride in the heat ${ }^{23}$ and more recently after a marathon ${ }^{24}$ showed only minor or no systemic endotoxemia.

Endotoxins are in vivo a main trigger for the host immune response via the induction of the cytokine network. TNF-alpha (tumor necrosis factor), one of the cytokines is presumed to be the central inflammatory mediator ${ }^{25}$. TNF-alpha is produced by macrophages and monocytes. It stimulates the production of other cytokines by the monocyt and other cells, including endothelial cells. Other pro-inflammatory cytokines include interleukin-1 (IL-1) and IL-6. Upon intravenous administration of a bolus of 2-4 ng endotoxin/ $\mathrm{kg}$ body weight to human volunteers, TNF-alpha first appeared 45 min post-infusion in the circulation, peaked at 90 min and then rapidly declined towards pre-infusion levels after 6 hours $^{26,27}$. IL-1 could not be detected while IL-6 appeared at $60 \mathrm{~min}$ in the circulation, peaked at $120 \mathrm{~min}$ and then also disappeared rapidly ${ }^{26,27}$. TNF-alpha, IL-1 and IL-6 have many biological effects, including the triggering of the acute phase response ${ }^{28-31}$. This involves substantial changes in plasma concentrations of many proteins in response to bodily harm, e.g. an increased inflammatory or surgical situation. Both increases and decreases in plasma protein concentrations, the so-called positive and negative acute phase responses, occur due to a change in their synthesis in the liver ${ }^{28}$. IL-6 induces the full spectrum of the acute phase reaction whereas IL-1 and TNF-alpha only lead to a partial acute phase reaction ${ }^{29-31}$. Pre-albumin and C-reactive protein (CRP) are good examples of negative and positive acute phase reactants, respectively. After the onset of inflammation or tissue injury, the CRP concentration starts to increase after 4-6 hours and peaks at 36-50 hours ${ }^{32}$. The development of the pre-albumin concentration is not well known.

The first aim of the study was to investigate whether there is endotoxemia in the 16 hours after a long distance triathlon. We also measured IgG-anti-endotoxin antibody concentrations, as they are expected to decrease over a time period more prolonged than that of a potential endotoxin peak, due to formation of endotoxin-anti-endotoxin complexes and subsequent breakdown of 
the protein complex. Furthermore, decreases in anti-endotoxin may also be seen when endotoxin would be produced locally only (e.g. in gut and portal vein) without appearing in the systemic circulation. We also measured the cytokines TNF-alpha and IL-6 as possible mediators of the endotoxin-induced effects, and C-reactive protein and pre-albumin as indicators of the acute phase reaction induced by those mediators.

A second aim of the study was to study the relation between gastro-intestinal complaints and the measured indirect markers of the gut barrier function: endotoxemia, the cytokine and the acute phase response.

In order to study the effects of extreme exercise we have chosen for a long distance triathlon (3.8 km swimming, $186 \mathrm{~km}$ cycling and $42.2 \mathrm{~km}$ running) in Embrun, France. This triathlon is believed to be one of the most challenging worldwide. The conditions of this race are extreme (high temperatures, altitude, long duration) and thus the prevalence of gastrointestinal symptoms and possibly endotoxemia were expected to be high.

\section{Methods}

\subsection{Subjects and protocol}

Twenty-nine male triathletes and 1 female triathlete were recruited for this study. All subjects were instructed and informed about the procedures of the study and they signed a consent form. Subject's age and weight were $33.0 \pm 6.0$ years and $72.3 \pm 7.3 \mathrm{~kg}$, respectively. The Ironman distance triathlon in Embrun (Embrunman) in France helt on the 15th of August 1996 was chosen because this is supposed to be one of the most challenging long distance triathlons. After the swim $(3800 \mathrm{~m}$ ) in open water, athletes cycled a course of $185 \mathrm{~km}$ in the mountains (Alps) with an altitude difference of $3600 \mathrm{~m}$. Subsequently the athletes ran $42.2 \mathrm{~km}$, partly on unpaved roads. The environmental conditions were $9.4^{\circ} \mathrm{C}$ in the morning at the start $(6.00 \mathrm{AM})$ with a high of $32.1^{\circ} \mathrm{C}$ around $14.00 \mathrm{PM}$. The water temperature was $18.6^{\circ} \mathrm{C}$ at the start.

The day before the start a blood sample was collected as well as immediately after the finish, one hour, two hours and 15-20 hours after the finish. The blood was used for the measurement of endotoxin, anti-endotoxin, TNF-alpha, IL-6, CRP and pre-albumin. The day before the triathlon, one hour before the start and immediately after the triathlon body mass was measured. Before and immediately after, the athletes completed a questionnaire.

\subsection{Questionnaire}

A questionnaire (20 items) was provided two or three days prior to the race with questions regarding training background, performance level, experience, preparation and the use of supplements. A second questionnaire (96 items) was provided directly after the race and athletes were asked to complete the questionnaire within 2 hours after finishing. This second 
questionnaire contained questions regarding the occurrence of gastro-intestinal symptoms during swimming, cycling, running and in the hours after the race. In case subjects abandoned the race questions were included to obtain the reason of abandoning.

Fluid loss was estimated from weight loss and corrected for fluid intake.

\subsection{Body mass and fluid balance}

Weight was recorded the day before the triathlon, one hour before the start and immediately after the race. Subjects were carefully instructed to report fluid and solid food intake during the race as accurately as possible. Fluid intake was estimated from the reported beverage (and solid food) intake. Immediately after the race, athletes were also asked to write down as accurately as possible what beverages and solid food they consumed during the race and in which amounts. The nutritional composition of dietary intake during the race was calculated through information from producers of particular products or the Dutch Nutritional (NEVO) tables.

\subsection{Analyses}

At each time point three samples of $4.0 \mathrm{ml}$ heparin-anticoagulated blood was collected (Endo Tube, Chromogenix AB, Mölndahl, Sweden) and $5.0 \mathrm{ml}$ non-anticoagulated blood. The tubes with the heparinised blood were immediately placed on melting ice. One was centrifuged at $180 \mathrm{x} \mathrm{g}$ and $4^{\circ} \mathrm{C}$ for $10 \mathrm{~min}$ to prepare platelet-rich plasma (PRP) for the endotoxin assays. The PRP samples were divided in two aliquots and stored at $-20^{\circ} \mathrm{C}$. The two other tubes were centrifuged at $3000 \mathrm{x} \mathrm{g}$ and $4^{\circ} \mathrm{C}$ for $10 \mathrm{~min}$ to prepare platelet-poor plasma (PPP) for the TNFalpha and IL-6 assays. The PPP was divided in $500 \mu \mathrm{l}$ aliquots. The $5 \mathrm{ml}$ non-anticoagulated blood was allowed to clot for at least $30 \mathrm{~min}$ at ambient temperature to prepare serum, centrifuged at $3000 \mathrm{x} \mathrm{g}$ at $4^{\circ} \mathrm{C}$ for $10 \mathrm{~min}$, and aliquots of $500 \mu \mathrm{l}$ stored at $-20^{\circ} \mathrm{C}$. The serum was used for the anti-endotoxin, pre-albumin and CRP assays.

Blood was also collected from 20 healthy untrained male volunteers (Mean age 38 years, range 20-55) to determine reference ranges of anti-endotoxin, IL-6, pre-albumin and CRP. The reference ranges were determined in male volunteers because 29 of the 30 athletes were also male.

\subsection{Endotoxin}

Endotoxin was assayed with chromogic assays obtained from Boehringer Ingelheim Whittaker (Verviers, France, the $\beta$-glucan insensitive endotoxin assay) and Chromogenix AM, Mölndal, Sweden, the more $\beta$-glucan sensitive endotoxin assay), as described previously ${ }^{33-35}$. Briefly, the PRP samples were thawed 5 min at $37^{\circ} \mathrm{C}$, dilluted 10 -fold with pyrogenfree water and heated for $15 \mathrm{~min}$ at $75^{\circ} \mathrm{C}$ to remove inhibitory activity from the plasma. After cooling to room temperature for 1 hour, $50 \mu \mathrm{l}$ aliquots were transferred to a microtiterplate. After incubation at $37^{\circ} \mathrm{C}$ with $50 \mu \mathrm{LAL}$ reagent (Biowhittaker $30 \mathrm{~min}$, Chromogenix $12 \mathrm{~min}$ ) and the subsequent

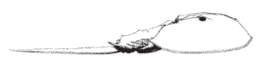


chromogenic substrate (Biowhittaker $6 \mathrm{~min}$ and Chromogenix $8 \mathrm{~min}$ ) the reaction was stopped with acetic acid and the yellow colour read at $405 \mathrm{~nm}$. Readings were compared with a standard curve prepared in human PRP with the E.coli 0111:B4 standard provided by the manufacturers according to the same procedure and treated simultaneously with the test samples. With this standard $1.2 \mathrm{EU} / \mathrm{ml}$ corresponds to approximately $120 \mathrm{pg} / \mathrm{ml}$.

\subsection{IgG anti-endotoxin}

IgG anti-endotoxin was assayed by ELISA with reagents (Endocab) that were kindly provided by Chromogenix AB, Mölndal, Sweden. Briefly, serum samples were thawed at room temperature and diluted 200-fold in the sample buffer provided in the kit. Then $100 \mu \mathrm{l}$ of this diluted sample or standards were added to a microtiterplate. This microtiterplate had been precoated with a mixture of endotoxin by the manufacturer. After incubation at $37^{\circ} \mathrm{C}$ for $60 \mathrm{~min}$ to bind the endotoxin antibodies in the serum to the plate, the plate was washed three times with wash-buffer. Then $100 \mu$ of an antibody to human IgG was added, which had been conjugated to alkaline phosphatase. After incubation for $60 \mathrm{~min}$ at $37^{\circ} \mathrm{C}$, the plate was washed three times with wash buffer and five times with destilled water. Then $100 \mu \mathrm{l}$ of a freshly prepared substrate solution of $800 \mu \mathrm{M}$ p-nitrophenyl phosphate was added, incubation continued for $60 \mathrm{~min}$ at ambient temperature and in the dark, the reaction was stopped by addition of $50 \mu \mathrm{l} 6 \mathrm{~N} \mathrm{H}_{2} \mathrm{SO}_{4}$ and the absorbance read at $405 \mathrm{~nm}$. Endocab is expressed in Median Units/ml (MU/ml), i.e. the median level observed in a group of 100 volunteers tested by the manufacturer.

\subsection{TNF-alpha and IL-6}

In the assays for TNF-alpha and IL-6, Endo tube ET collection tubes were used to avoid any contamination with endotoxin and thus to avoid higher levels of TNF-alpha and IL-6 due to in vitro activation of blood cells. TNF-alpha and IL-6 were determined by ELISA (Pelikine Compact ${ }^{\mathrm{TM}}$ TNF-alpha and IL-6 ELISA kits; Central Laboratory of the Netherlands Red Cross Blood Transfusion Service; The Netherlands).

\subsection{CRP}

CRP was determined by nephelometry on a Hitachi 911 analyser (Boehringer Mannheim, Mannheim, Germany) with reagents and according to the instructions provided by this supplier.

\subsection{Pre-albumin}

Pre-albumin was determined by nephelometry on an auto-analyser (ARRAY, Beckmann Instruments Inc., Breda, The Netherlands), with reagents and according to the instructions provided by this supplier. 


\subsection{CK}

Creatine kinase (CK) was determined by spectrophotometry on a Hitachi 747 analyser (Boehringer Mannheim, Mannheim, Germany) with the NAC-activated CK reagent kit and according to the instructions provided by this supplier.

\subsection{Statistics}

The gastro-intestinal symptoms were divided in two categories: severe symptoms and less severe symptoms. Severe symptoms included nausea, vomiting urge, vomiting, stomachache and intestinal cramps. Nausea, stomachache, intestinal cramps and urge to vomit were only registered as severe symptoms when a score of 5 or higher out of 10 was given. Less severe symptoms included eructation, flatulence, urge to defecate, heartburn and abdominal pressure (bloating). Nausea, stomachache, intestinal cramps and urge to vomit were registered as nonsevere symptoms when a score below 5 was given.

Symptoms reported during cycling and running were compared to endotoxin and anti-endotoxin concentrations as well as with the parameters of the cytokine and acute phase response using a Spearman Rank Correlation test. Gastro-intestinal complaints reported during swimming were ignored because it is unlikely that these complaints would be related to endotoxemia.

A one-way ANOVA was used to detect changes over time. In case of significance, the difference was located with a Tukey post-hoc test. To study the difference in measured blood parameters between the triathletes and untrained healthy control subjects an unpaired t-test was applied. In all cases the level of significance was set at $\mathrm{P}<0.05$ and all results were expressed as mean \pm SEM.

\section{Results}

\subsection{Study group}

Because of incomplete data collection, one subject was discarded. Four out of the remaining 29 participants abandoned the race (14\%). The reasons for abandoning varied among athletes. Two of them could not continue because of gastro-intestinal problems, two abandoned because of muscle cramping and muscle soreness or lower back problems.

\subsection{Gastro-intestinal complaints}

The vast majority of the subjects (93\%) reported some gastro-intestinal symptoms, most of them being non severe. The most reported complaints were flatulence and eructation. There was also a relatively high prevalence of severe symptoms (Table 1 ). Six subjects $(21 \%)$ reported an urge to vomit during either cycling or running and these subjects also vomited. One athlete reported diarrhea during cycling and one during running. Two athletes abandoned the race because of severe gastro-intestinal problems including diarrhea, stomach cramping, vomiting and nausea. 
Table 1. Gastro-intestinal and related complaints during the triathlon.

\begin{tabular}{llllll}
\hline Complaints & $n$ & $\%$ & Complaints & $n$ & $\%$ \\
\hline Stomach problems & 9 & 31 & Stomach cramps & 3 & 10 \\
Nausea & 6 & 21 & Intestinal cramps & 4 & 14 \\
Dizziness & 2 & 7 & Urge to vomit & 6 & 21 \\
Head ache & 3 & 10 & Vomiting & 6 & 21 \\
Flatulence & 11 & 38 & Diarrhea & 2 & 7 \\
Urge to urinate & 19 & 66 & Side ache left & 1 & 3 \\
Urge to defecate & 4 & 14 & Side ache right & 3 & 10 \\
Belching & 10 & 35 & Muscle cramps & 6 & 21 \\
Heartburn & 2 & 7 & Cold shivering & 3 & 10 \\
Bloating & 7 & 24 & & & \\
\hline
\end{tabular}

Nausea, stomachache, intestinal cramps and urge to vomit were only registered when a score of 5 or higher (out of 10) was given.

\subsection{Assays}

The mean endotoxin concentration as measured with the $\beta$-glucan insensitive assay showed an increase immediately post-exercise and was more pronounced 1 hour after the race (Figure 1). The highest measured value was $15.0 \mathrm{pg} / \mathrm{ml}$. When it is assumed that endotoxemia is present at endotoxin concentrations $>5.0 \mathrm{pg} / \mathrm{ml}^{20,24}$, at 1 hours after the race, $68 \%$ of the athletes had endotoxemia. At 2 hours after the race only $19 \%$ of the athletes had endotoxemia which was increased again 16 hours after the race (79\%). With the $\beta$-glucan sensitive assay a similar pattern in the endotoxin concentrations was observed, but the highest level of endotoxin-active material was measured immediately after the race.

IgG anti-endotoxin levels did not change directly and 1 hour after the race but showed a tendency to decline after 2 hours. After 16 hours anti-endotoxin had declined significantly compared to the levels at rest and the first 2 hours after exercise. The TNF-alpha, IL-6, CRP and pre-albumin concentrations are presented in Figure 2.

The TNF-alpha concentration was $0.84 \pm 0.20 \mathrm{pg} / \mathrm{ml}$ before the race and did not change significantly at any of the study periods.

The IL- 6 concentration showed a significant average 27 -fold increase immediately after the race and then decreased slowly. The day after the race (16 h) IL-6 had returned to pre-race levels.

The CRP concentration was elevated $2 \mathrm{~h}$ after the race compared to rest $(1.53 \pm 0.11 \mu \mathrm{g} / \mathrm{ml})$ and was on average increased 20 -fold 16 hours after the race to a mean of $30.2 \pm 3.0 \mu \mathrm{g} / \mathrm{ml}$. One subject had a CRP concentration of $62.4 \mu \mathrm{g} / \mathrm{ml}$. 

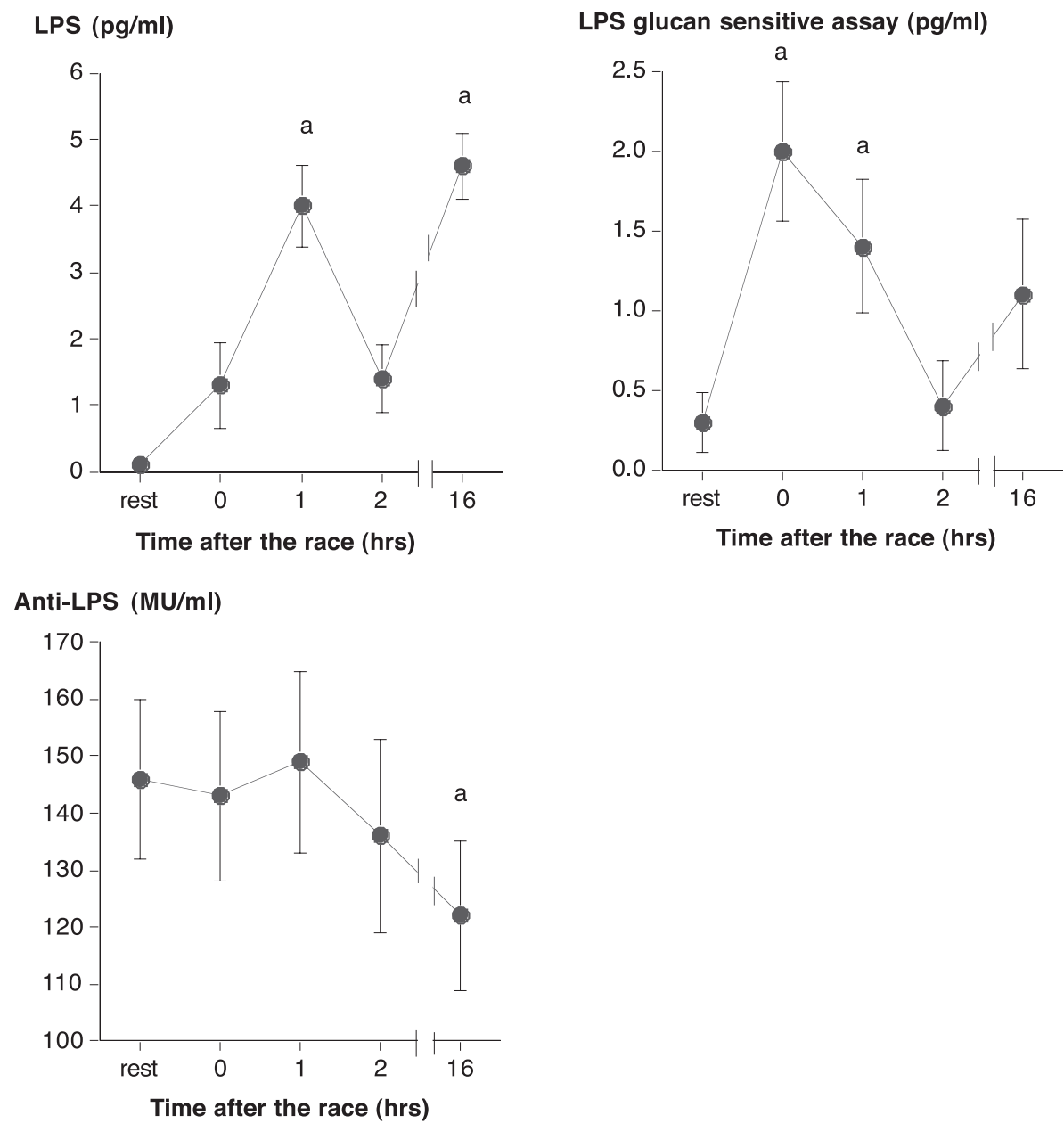

Figure 1: Endotoxin measured with a $\beta$-glucan insensitive and a more $\beta$-glucan sensitive endotoxin assay and $\mathrm{IgG}$ anti-endotoxin before and at several time points after the triathlon. Values are presented as mean \pm SEM.

a indicates a significant $(\mathrm{P}<0.05)$ elevation compared to the pre-race values.

The pre-albumin concentration was slightly elevated immediately after the race and started to decrease in the hours after the race. At 16 hours after the race the pre-albumin concentration was significantly lower than the concentrations on the day of the race.

Plasma CK concentrations were significantly elevated after exercise and continued to increase the hours after the race. This increase however, was not correlated with changes in IL-6 concentration (Spearman rank correlation coefficient $\left(r_{s}\right) 0.174 \mathrm{p}=0.366$ ). Similarly, no correlation was found between CK and changes in TNF-alpha concentration $\left(\mathrm{r}_{\mathrm{s}}-0.139 \mathrm{p}=0.473\right)$, between $\mathrm{CK}$ and changes in CRP concentration $\left(\mathrm{r}_{\mathrm{s}} 0.363 \mathrm{p}=0.053\right)$, and between $\mathrm{CK}$ and changes in pre-albumin concentration $\left(\mathrm{r}_{\mathrm{s}} 0.244 \mathrm{p}=0.220\right)$. 


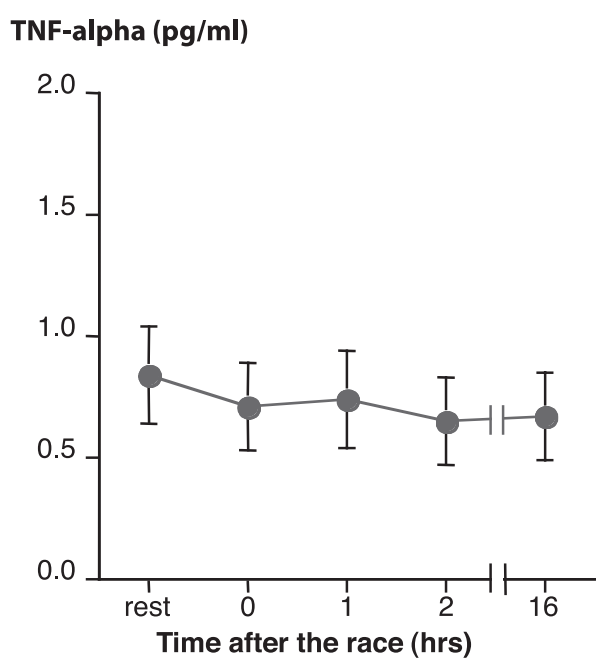

\section{$\operatorname{CRP}(\mu \mathrm{g} / \mathrm{ml})$}

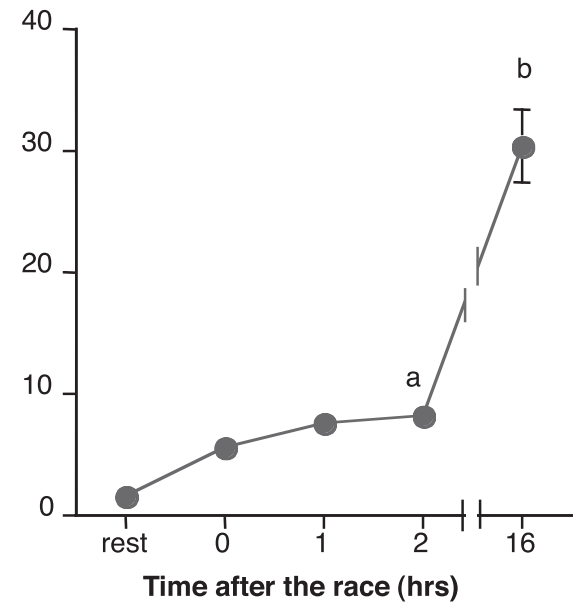

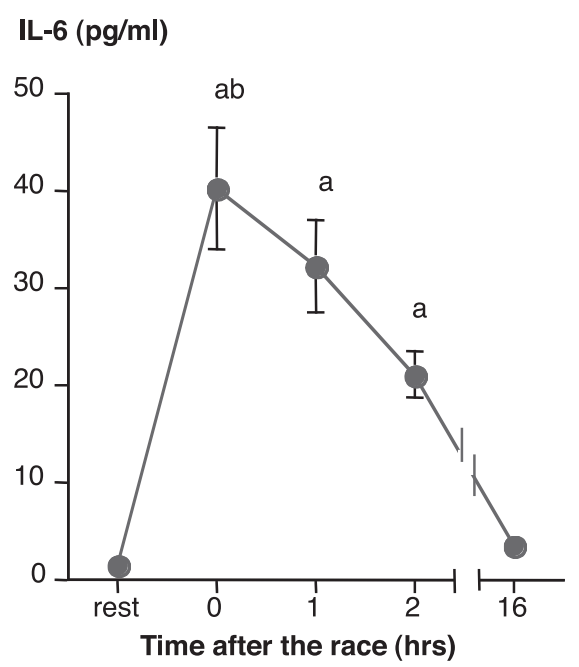

Pre-albumin $(\mu \mathrm{g} / \mathrm{ml})$

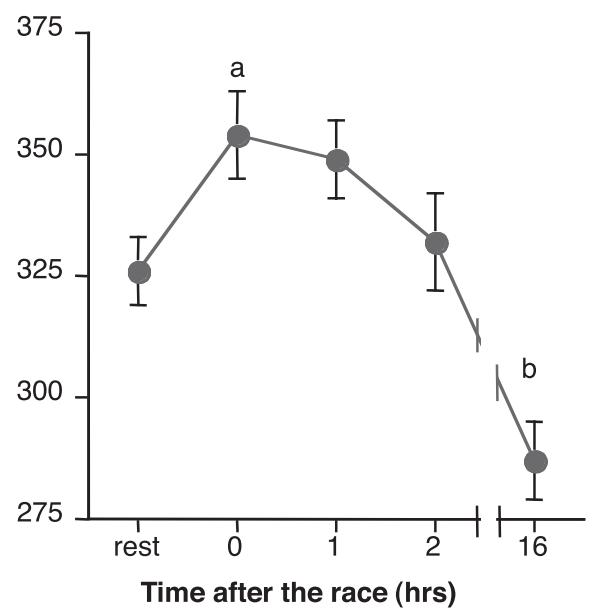

Figure 2: IL-6, TNF-alpha and the positive and negative acute phase response proteins CRP and prealbumin concentrations before and at several time points after the triathlon. Values are presented as mean \pm SEM.

a indicates a significant $(\mathrm{P}<0.05)$ change compared to resting values

b indicates a significant $(\mathrm{P}<0.05)$ change compared to 2 hours after the race.

Increases in endotoxin and $\mathrm{IgG}$ anti-endotoxin were not correlated with any of the gastrointestinal symptoms during running and cycling (data not shown). The change in IL-6 concentration from rest to directly after the race showed a significant correlation with vomiting and diarrea during running (Table 2). Markers of the acute phase response (CRP and prealbumin) also showed a significant correlation with the incidence of diarrea during running. Additionally, these two markers of the acute phase response were correlated with the score for 


\section{CK}

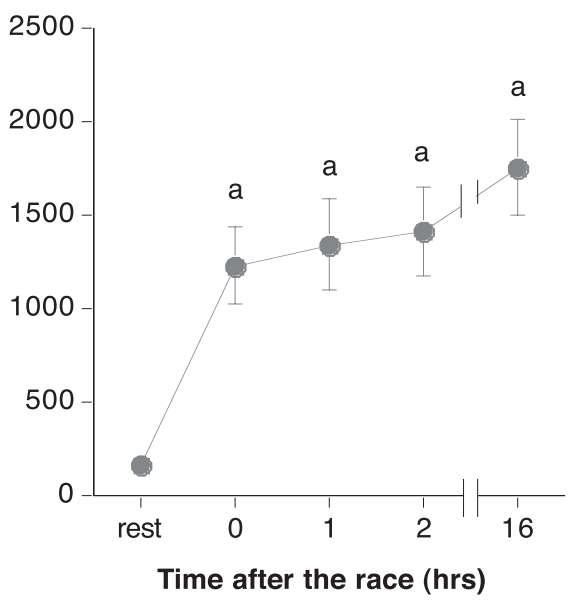

Figure 3: CK response after the triathlon. Values are presented as mean \pm SEM.

an indicates a significant $(\mathrm{P}<0.05)$ change compared to pre-race values.

intestinal cramps during running. The responses for the two athletes who abandoned the race because of GI-problems were similar to those of athletes with little or no GI-complaints.

Reference values were obtained in healthy untrained control subjects for anti-endotoxin (mean $242 \mathrm{MU} / \mathrm{ml}$, range 65-470 MU/ml), IL-6 (mean $1.1 \mathrm{pg} / \mathrm{ml}$, range 0.7-6.5), pre-albumin (mean $322 \mu \mathrm{g} / \mathrm{ml}$, range $200-494 \mu \mathrm{g} / \mathrm{ml}$ ) and CRP (mean $2.47 \mu \mathrm{g} / \mathrm{ml}$, range 0.74-6.21 $\mu \mathrm{g} / \mathrm{ml}$ ) (Table 3).

Table 2. Correlations between changes in CRP, IL-6 and pre-albumin versus gastro-intestinal complaints.

\begin{tabular}{llll}
\hline & $\Delta$ CRP & $\Delta$ IL-6 & $\Delta$ pre-albumin \\
\hline Nausea & 0.259 & 0.155 & 0.223 \\
Dizziness & 0.350 & 0.264 & $0.503^{*}$ \\
Intestinal cramps & $0.397^{*}$ & 0.174 & $0.533^{* *}$ \\
Vomiting & 0.381 & $0.268^{*}$ & 0.165 \\
Diarrhea & $0.511^{*}$ & $0.504^{*}$ & $0.529 * *$ \\
\hline
\end{tabular}

The presented values are Spearman rank correlation coefficients ( $r$ ) and * indicates $P<0.05$ (** indicates $P<0.01)$. The changes in CRP, IL-6 and pre-albumin were expressed as a $\Delta$ value of each athlete between rest and the value at the time point of maximum response; for IL-6 immediately after the race, for CRP and prealbumin 16 hours after the race.

Table 3. Resting values of endotoxin, IgG anti-endotoxin, IL-6, TNF-alpha, CRP and pre-albumin in triathletes and untrained controls.

\begin{tabular}{llll}
\hline & Control & Triathletes & P-value \\
\hline IgG anti-endotoxin $(\mathrm{MU} / \mathrm{ml})$ & $242 \pm 28$ & $146 \pm 14^{*}$ & 0.0013 \\
IL-6 $(\mathrm{pg} / \mathrm{ml})$ & $1.1 \pm 0.2$ & $1.5 \pm 0.3$ & 0.3444 \\
CRP $(\mu \mathrm{g} / \mathrm{ml})$ & $2.47 \pm 0.34$ & $1.53 \pm 0.11^{*}$ & 0.0033 \\
Pre-albumin $(\mu \mathrm{g} / \mathrm{ml})$ & $322 \pm 15$ & $326 \pm 7$ & 0.8238 \\
\hline
\end{tabular}

* indicates statistical significance $(P<0.05)$. 
Compared to a group of healthy but untrained individuals, the athletes had lower concentrations of anti-endotoxin and lower CRP concentrations at rest (Table 3). No differences were observed in IL-6 and pre-albumin concentrations.

\section{Discussion}

The athletes in the present study showed some symptoms usually seen with endotoxemia, i.e., dizziness, nausea, and vomiting during and after the race. One third of the athletes had stomach problems, $21 \%$ of the athletes were nauseous, $7 \%$ experienced dizziness, 6 athletes (21\%) vomited and two had diarrhea. Two athletes had to abandon the race because of severe gastro-intestinal distress (vomiting and diarrhea). These gastrointestinal (GI) problems are often reported by endurance athletes during long races, especially in the heat and especially when running is involved as shown by numerous surveys and case studies ${ }^{14-16}$. Although there was a high incidence of gastro-intestinal complaints in the present study, including several severe symptoms, only mild endotoxemia was observed in the athletes investigated (i.e, endotoxin just above the $5 \mathrm{pg} / \mathrm{ml}$ threshold used to define endotoxemia). The degree of endotoxemia was not related to the incidence or the severity of the complaints. However, the cytokine response, which might have evolved from the endotoxemia, was correlated with gastro-intestinal complaints. Especially the IL-6 concentration was correlated to severe complaints (diarrhea and vomiting) (Table 2). No correlation, however, was observed between IL-6 and endotoxin.

The finding of mild endotoxemia in these extreme conditions is seemingly in contrast with two other studies ${ }^{19-21}$, which reported a high incidence of extreme endotoxemia in athletes participating in a $90 \mathrm{~km}$ run (Comrades Marathon) and a long distance triathlon, respectively. In the study by Brocke-Utne et al. ${ }^{19}, 81 \%$ of the investigated athletes had endotoxin levels above $100 \mathrm{pg} / \mathrm{ml}$ whereas in the present study the highest measured endotoxin level was $15 \mathrm{pg} / \mathrm{ml}$. One explanation for the discrepancies may be the fact that the athletes studied by Brocke-Utne et al. ${ }^{19}$ were exhausted runners who had to abandon the race because of gastro-intestinal complaints, dehydration and heat shock, whereas in the present study $86 \%$ of the participants in the study were able to finish the race.

However, similar observations to Brocke-Utne et al. ${ }^{19}$ were made by Bosenberg et al. ${ }^{21}$, who studied 18 triathletes and observed that plasma endotoxin rose from a mean of $81 \mathrm{ng} / \mathrm{ml}$ to 294 $\mathrm{ng} / \mathrm{ml}$. It must be kept in mind, however, that the reported resting endotoxin concentrations in those studies were already higher than those observed in patients with a septic shock and thus analytical differences may be responsible for the discrepancies between the two abovementioned studies and the present study. When a similar endotoxin assay was performed by Camus et al. ${ }^{24}$ the results seem to be in agreement with our findings. In that study very mild endotoxemia (between 5 and $14 \mathrm{pg} / \mathrm{ml}$ ) was observed after a marathon in 8 of 18 athletes whereas one athlete had a high endotoxin level of $72 \mathrm{pg} / \mathrm{ml}^{24}$. 
The analysis of endotoxin in plasma is critically dependent upon several issues, which may be responsible for the discrepancy in the findings in the present study and those of BrockeUtne et al. ${ }^{19}$ and Bosenberg et al. ${ }^{21}$ endotoxin are usually determined with the LAL (Limulus Amoebocyte Lysate) assay ${ }^{34 ; 35}$. This assay is based on the property of endotoxin to activate the clotting cascade, which is present in the circulating cell (amoebocyte) of Limulus polyphemus, the horseshoe crab. With this assay it is possible to detect very low levels of endotoxin in plasma ( $3 \mathrm{pg} / \mathrm{ml}$ or $0.036 \mathrm{EU} / \mathrm{ml}$ ), which is essential because endotoxemia in man is already considered to be present above $5 \mathrm{pg} / \mathrm{ml}^{20}$. A first critical issue is the fact that plasma contains inhibitory substances that have to be removed prior to the endotoxin assay. A dilution and heating procedure is usually the method of choice ${ }^{36}$. Details of the method to remove the inhibitory activity in plasma are not always indicated. This makes it difficult to estimate the validity of the methodology. However, an inappropriate method would result in too low endotoxin concentrations and therefore cannot be the reason for the relatively high reference values obtained by the investigators reporting high endotoxin concentrations ${ }^{19-21}$.

Secondly, the reference ranges in the other studies ${ }^{19-21}$ are rather high, i.e. between 64 and 100 $\mathrm{pg} / \mathrm{ml}$, and would therefore be in the range of septic patients. The articles are not providing sufficient details of their methodology. For instance, if the other investigators used a standard curve prepared in water instead of PRP, a factor 10 difference in results will be obtained due to a lesser endotoxin activity in water. Also, the factor 10 dilution of the PRP is frequently not taken into account if the results are expressed as $\mathrm{pg} / \mathrm{ml}$. We therefore always prepare the standard curve in PRP and express our results in $\mathrm{pg} / \mathrm{ml}$ PRP (or EU/ml PRP).

Thirdly, the LAL reagent may not only react to endotoxin but can also be sensitive to $\beta$-glucan if a chloroform extraction procedure is used to prepare the LAL reagent, which is usually the case. $\beta$-Glucan is present in fungi and can be present in the membranes used in hemodialysis and other cardio pulmonary bypass devices ${ }^{36}$. In the present study both a $\beta$-glucan insensitive and a more $\beta$-glucan sensitive endotoxin assay were used. The two assays gave similar patterns of the endotoxin levels, but immediately post-race the $\beta$-glucan sensitive assay gave higher results than the $\beta$-glucan insensitive assay. This could indicate that fungal material, also likely to originate from the intestine, is especially present in the circulation at that study period. It is unclear whether the LAL in the other two studies ${ }^{19-21}$ was $\beta$-glucan sensitive.

Another method to investigate whether endotoxin has appeared in the circulation is to measure the plasma anti-endotoxin concentration. In a study in racehorses, the IgG anti-endotoxin concentration was significantly reduced after the race ${ }^{22}$. Also, both the pre- and post-race IgG anti-endotoxin levels were lower than the values measured in untrained horses, which could indicate that training and competition leads to endotoxin leakage into the circulation and subsequent increase in the specific antibody production ${ }^{21}$. Similarly, serum IgG anti-endotoxin concentrations were negatively correlated to the endotoxin concentrations in the circulation in 
long-distance runners ${ }^{19}$. In agreement with the findings in racehorses we observed $40 \%$ lower $\mathrm{IgG}$ anti-endotoxin levels in our trained subjects compared to untrained controls. It can not be excluded that the lower anti-endotoxin level in trained athletes may be due to some endotoxin leakage during training sessions in the weeks preceding the race, leading to the formation of endotoxin - anti-endotoxin complexes, which may be rapidly broken down, thereby decreasing the levels of anti-endotoxin. The observed reduction in $\mathrm{IgG}$ anti-endotoxin 16 hours following the triathlon suggests that there is a continuous leakage of endotoxin into the circulation in the first hours after this extreme exercise.

It is known that endotoxin is a potent activator of the cellular and humoral host-defence systems. Blood monocytes and tissue macrophages secrete several cytokines like TNF-alpha and IL-6 upon activation by bacterial endotoxins ${ }^{27,37}$. TNF-alpha did not change after the race, whereas the IL-6 concentration increased substantially. In this study the cytokine response to endotoxin was partly detected. TNF-alpha did not change, which is in agreement with some ${ }^{38 ; 39}$ but not all ${ }^{24}$ studies. Northoff and Berg ${ }^{38}$ were unable to detect TNF-alpha at the completion of a marathon whereas TNF-alpha also stayed below the levels of detection in a study by Rohde et al. ${ }^{39}$, both measured by an ELISA assay. Our failure to detect TNF-alpha is not surprising if one considers the much more serious conditions of sepsis. In studies involving 97 to 146 patients with sepsis, only $4-54 \%$ of the patients had detectable levels of TNF-alpha in the circulation ${ }^{40}$. This may be due to the rapid clearance of TNF-alpha in the circulation ${ }^{40}$.

Increased IL-6 levels were demonstrated in 28 of the 29 athletes in this study, which confirms observations by other investigators after various exercise conditions ${ }^{41}$ including a marathon ${ }^{24}$. Upon activation by bacterial endotoxins, blood monocytes and tissue macrophages secrete several cytokines including IL-6 ${ }^{27,37}$. The increased IL-6 levels observed here may thus be another indication that endotoxemia occurred during and after the triathlon. However, there seemed to be no direct correlation between IL- 6 and endotoxin and it cannot be excluded that the elevated IL-6 levels were caused by the exercise itself or by muscle damage as a result of exercise. Bruunsgaard et al. ${ }^{42}$ recently showed that serum IL-6 was significantly increased after 2 hours eccentric exercise but not after 2 hours concentric exercise. IL- 6 may thus be related to muscle damage, especially since serum IL-6 concentrations were significantly correlated with creatine kinase (CK), a parameter often used to indicate muscle damage. The athletes in the present study encountered a fair amount of downhill running and thus eccentric exercise. However, in the present study we could not find a correlation between the cytokine- and acute phase response and plasma CK levels (Figure 3). CK was significantly increased after the race, as were IL- 6 and pre-albumin but the magnitude of the increase in IL- 6 and pre-albumin was not related to the CK levels. Although there was a tendency for the increase in CRP to be correlated with $\mathrm{CK}$, the correlation was not strong and statistically not significant. 
Camus et al. ${ }^{24}$ concluded that the relationship between alterations in gut-barrier function, endotoxin translocation and the cytokine responses after exercise is, at least in quantitative terms far from being established. As in the present study, these authors did not find a correlation between endotoxin or anti-endotoxin and the concentration of cytokines after strenuous exercise.

IL-6 is one of the main stimuli of the acute phase reaction, which was indeed present in these athletes. CRP as participant of the positive acute phase reaction, and pre-albumin representing the negative acute phase reaction, were especially increased and decreased, respectively, in the samples collected 16 hours after the race. Elevations of positive acute phase proteins have been reported by others ${ }^{43-46}$. Dufaux et al ${ }^{43}$ and Liesen et al. ${ }^{44}$ reported a 6-fold increase in CRP one day after a 2 hour and 3 hour run, respectively, while a peak may be observed 24 hours after a strenuous exercise ${ }^{46}$. Castell et al. ${ }^{45}$ reported a 4-fold increase in CRP levels 16 hours after a marathon. These results seem to be in agreement with the results of this study in which we found CRP to be increased 20-fold and pre-albumin decreased $12 \% 16$ hours after the race.

It is possible that the long training background and the large number of training hours before participation increased the endotoxin resistance and reduced the pro- and anti-inflammatory responses. Rats that were repeatedly injected with endotoxin, show a significantly improved survival rate when exposed to the heat, which has been attributed to increased circulating antiendotoxin antibodies, increased reticulo-endothelial phagocyte capacity, increased tolerance to TNF-alpha toxicity, and reduced inflammatory reactions by endotoxin-stimulated cells ${ }^{47}$. However, here we did not see a relation between training background or the amount of training and the concentrations of endotoxin, anti-endotoxin, IL-6 or TNF-alpha. However, we did observe $40 \%$ lower IgG anti-endotoxin levels in our trained subjects compared to untrained controls. This may indicate that previous training resulted in endotoxin leakage into the circulation. Resting CRP levels were lower in the athletes. However, this may be attributed to the high CRP levels of three of the control subjects, possibly caused by smoking behaviour or an infection.

These results suggest that endotoxin leakage is a situation that is inherent to the large training loads as applied by these endurance athletes and may occur frequently without causing systemic endotoxemia.

In conclusion, mild systemic endotoxemia was observed in some athletes in the hours after exercise while anti-endotoxin levels were significantly decreased 16 hours after exercise suggesting that there was portal vein endotoxemia during and after exercise. However, there was no correlation between the extent of systemic endotoxemia and the severity of GI-complaints suggesting that systemic endotoxemia is not a direct cause of GI-complaints. There was a clear cytokine response immediately after exercise and a clear acute phase response the day after exercise, and both of them did positively correlate with some of the severe GI-complaints (e.g. 
diarrhea, vomiting) during exercise. As both responses may have evolved from portal vein endotoxemia, we conclude that we find evidence in support of the hypothesis that the gut barrier function for bacterial endotoxins and potentially also for fungal beta glucans is lost during severe prolonged exercise and may lead to GI-complaints. Although it cannot be excluded that other exercise-induced inflammatory processes (e.g. muscle damage) also play a role in cytokine and acute phase activation, we did not find a correlation between $\mathrm{CK}$ and this activation.

\section{Acknowledgements}

The authors gratefully acknowledge Chromogenix AB, Mölndal, Sweden for their provision of the reagents for the anti-endotoxin assay and Quest International (Naarden, The Netherlands) for partial funding of this study. The authors would also like to thank Mr. Gerald Iacono, the organiser of the Embrunman for his kind cooperation and help and Dr Marble, head of the medical staff for help and medical assistance. Very much appreciated is also the help in sample collection by Dr. Bret Goodpaster, sample collection and preparation by Mr. Raymond Vet, the excellent analytical assistance of Ms. Marianne Schaap, Ms. Margo van Schie and Ms. Marja Kersbergen and help in data analysis by Ms. Evelijn Zeijdner. Lastly, we want to thank Ms. Eva Kovacs, Ms. Regina Schmahl and Mr. Benoit Marchal for the excellent translations of the questionnaires in Italian, German and French. 


\section{References}

1. Bradley S.E. Variations in hepatic blood flow in man during health and disease. N Engl J Med 1949; 240:456-461.

2. Rowell L.B., Blackmon J.R., Bruce, R.A. Indocyanine green clearance and estimated hepatic blood flow during mild to maximal exercise in upright man. J Clin Invest 1964; 43: 1677-1690.

3. Clausen J.P. Effect of physical training on cardiovascular adjustments to exercise in man. Physiol Rev 1973; 57:779-815.

4. Rowell L.B., O’Leary D.S., Kellogg D.L. Integration of cardiovascular control systems in dynamic exercise. In Handbook of Physiology, section 12: Exercise: Regulation and integration of multiple systems, (Rowell, L.B. and Shephard, J.T. eds.), Oxford Press, Newe York 1996; pp770-838.

5. Williams J.H., Mager M., Jaconson E.D. Relationship of mesenteric blood flow to intestinal absorption of carbohydrates. 1962; 63: 853-863.

6. Haglund U. Gut ischaemia. Gut 1994; suppl.1:S73-S76.

7. van Deventer S.J.H., Gouma D. Bacterial translocation and endotoxin transmigration in intestinal ischaemia and reperfusion. Curr Opinion Aneasth 1994; 7:126-130.

8. Schoenberg M.H., Berger H.G. Reperfusion injury after intestinal ischamia. Crit Care Med 1993; 21:1376-1386.

9. Perry M.A., Wadhwa S.S. Gradual reintroduction of oxygen reduces reperfusion injury in cat stomach. Am J Physiol 1988; 254:G366-G372.

10. van Leeuwen P.A.M., Boermeester M.A., Houdijk A.P.J., Ferwerda C.C., Guesta, M.A., Meyer, S., Wesdorp R.I.C. Clinical significance of translocation. Gut 1994; suppl. 1: S28-S34.

11. Rouns F., Saris W.H.M., Rehrer N.J. Abdominal complaints and gastrointestinal function during longlasting exercise. Int J Sports Med 1987; 8:175-189.

12. Rehrer N.J., Brouns F., Beckers E.J., Frey W.O., Villiger B., Riddoch C.J., Menheere P.P.C.A., Saris, W.H.M. Physiological changes and gastro-intestinal symptoms as a result of ultra-endurance running. Eur J Appl Physiol 1992; 64:1-8.

13. Rehrer N.J., Janssen G.M.E., Brouns F., Saris W.H.M. Fluid intake and gastrointestinal problems in runners competing in a 25-km race and a marathon. Int J Sports Med 1998; 10:S22-S25.

14. Keeffe E.B., Lowe D.K., Goss J.R., Wayne R. Gastrointestinal symptoms of marathon runners. West J Med 1984; 141:481-484.

15. Riddoch C., Trinick T. Gastrointestinal disturbances in marathon runners. Brit J Sports Med 1988; 22:71-74.

16. Sullivan S.N. The gastrointestinal symptoms of running. N Eng J Med 1981; 304, 915.

17. Schaub N., Spichtin H.P., Stalder G.A. Ischamische Kolitis als Ursache einer Darmblutung bei Marathonlauf? Schweiz Med Wschr 1985; 115:454-457.

18. Øktedalen O., Lunde O.C., Opstad P.K., Aabakken L., Kvernebo K. Changes in gastro-intestinal mucose after long-distance running. Scand J Gastroenterol 1992; 27:270-274.

19. Brock-Utne J.G., Gaffin S.L., Wells M.T., Gathiram P., Sohar E., James M.F., Morrell D.F., Norman R.J. Endotoxemia in exhausted runners after a long distance race. S Afr Med J 1988; 73:533-536.

20. van Deventer S.J.H., Buller H.R., ten Cate J.W., Sturk A., Pauw W. Endotoxemia: an early predictor of septicaemia in febrile patients. Lancet 1988; 19:605-608.

21. Bosenberg A.T., Brock-Utne J.G., Gaffin S.L., Wells M.T.B., Blake G.T.W. Strenuous exercise causes systemic endotoxemia. J Appl Physiol 1988; 65:106-108.

22. Baker B., Gaffin S.L., Wells B.C., Brock-Utne J.G. Endotoxemia in race horses following exertion. J South Afr Vet Assoc 1988; 59:63-66.

23. Moore G.E., Holbein M.E., Knochel J.P. Exercise-associated collapse in cyclists is unrelated to endotoxemia. Med Sci Sports Med 1995; 27:1238-1242.

24. Camus G., Poortmans J., Nys M., Deby-Dupont G., Duchateau J., Deby C., Lamy M. Mild endotoxemia and the inflammatory response induced by exercise. Clin Sci 1997; 92:415-422. 
25. Beutler B. Cachectin in tissue injury, shock and related states. Crit Care Clin 1989; 5:353-367.

26. van Deventer S.J.H., Büller H.R., ten Cate J.W., Aarden L.A., Hack C.E., Sturk A. Experimental endotoxemia in humans: analysis of cytokine release and coagulation, fibrinolytic and complement pathways. Blood 1990; 76:2520-2526.

27. Michie H.R., Manogue K.R., Spriggs D.R., Revhaug A., O’Dwyer S., Dinarello C.A., Cerami A., Wolf S.M., Wilmore D.W. Detection of circulating tumor necrosis after endotoxin administration. N Engl J Med 1988; 23:1481-1486.

28. Koj A. Definition and classification of acute phase proteins. The acute-phase response to injury and infection, edited by A. H. Gordon and A. Koj. Amsterdam: Elsevier 1985; 139-232.

29. Darlington G.J., Wilson D.R., Lachman L.B. Monocyte-conditioned medium, interleukin-1, and tumor necrosis factor stimulate the acute phase response in human hepatoma cells in vitro. J Cell Biol 1986; 103:787-793.

30. Perlmutter D.H., Dinarello C.A., Punsai P.I., Colten H.R. Cachertin/tumor necrosis factor regulate hepatic acute-phase gene expression. J Clin Invest 1986; 78:1349-1354.

31. Gauldie J., Richards C., Harnish D., Landsdorp P., Baumann H. Interferon b2/B-cells stimulatory factor type 2 shares identity with monocyte-derived hepatocyte-stimulating factor and regulates the acute phase response in liver cells. Proc Natl Acad Sci USA 1987; 84:7251-7255.

32. Jaye D.L., Waites K.B. Clinical applications of C-reactive protein in pediatrics. Pediatr Infect Dis J 1997; 16:735-747.

33. Roslansky P.F., Novitsky T.J. Sensitivity of Limulus amoebocyte lysate (LAL) to LAL-reactive glucans. J Clin Microbiol. 1991; 29:2477-2483.

34. Sturk A., Joop K., ten Cate J.W., Thomas L.L.M. Optimalization of a chromogenic assay for endotoxin in blood. Prog Clin Biol Res 1985; 189:117-137.

35. Sturk A., Janssen G.M., Muylaert F.R., Joop K., ten Cate J.W. Endotoxin testing in blood. Prog Clin Biol Res 1987; 231:371-385.

36. Obayashi T., Tamura H., Tanaka S., Ohki M., Takahashi S., Kawai T. Endotoxin-inactivating activity in normal and pathological human blood samples. Infect Immun 1986; 53:294-297.

37. Fong Y., Moldawer L.L., Marano M., Wei H., Tatter S.B., Clarick R.H., Santhanam U., Sherris D., May L.T., Seghal P.B., Lowry S.F. Endotoxemia elicits increased circulating beta 2-IFN/IL-6 in man. J Immunol 1989; 142:2321-2324.

38. Northoff H., Berg A. Immunological mediators as parameters of the reaction to strenuous exercise. Int J Sports Med 1991; 12: S9-S15.

39. Rohde T., MacLean D.A., Hartkopp A., Pedersen B.K. The immune system and serum glutamine during a triathlon. Eur J Appl Physiol 1996; 74:428-434.

40. Hack C.E., Aarden L.A., Thijs L.G. Role of cytokinesis in sepsis. Advances Immunol 1997; 66:101-195.

41. Northoff H., Weinstock C., Berg A. The cytokine response to strenuous exercise. Int J Sports Med 1994; 15:167-171.

42. Bruunsgaard H., Galbo H., Halkjaer-Kristiansen J., MacLean D.A., Pedersen B.K. Exercise-induced increase in serum interleukin-6 in humans is related to muscle damage. J Physiol 1997; 499:833-841.

43. Dufaux B., Order U., Geyer H., Hollmann W. C-reactive protein serum concentrations in well-trained athletes. Int J Sports Med 1984; 5:102-106.

44. Liesen H., Dufaux B., Hollmann W. Modifications of serum glycoproteins the day following a prolonged physical exercise and the influence of physical training. Eur J Appl Physiol 1977; 37:243-254.

45. Castell L.M., Poortmans J.R., Leclercq R., Brasseur M., Duchateau J., Newsholme E.A. Some aspects of the acute phase response after a marathon race, and effect of glutamine supplementation. Eur J Appl Physiol 1997; 75:47-53.

46. Weight L.M., Alexander D., Jacobs P. Strenuous exercise: analoguous to the acute-phase response? Clin Sci $1991 ; 81: 677-683$.

47. Ryan A.J. Heat stroke and endotoxemia: sensitization or tolerance to endotoxins? Perspectives in exercise science 1992; 335-385 



\section{CHAPTER}

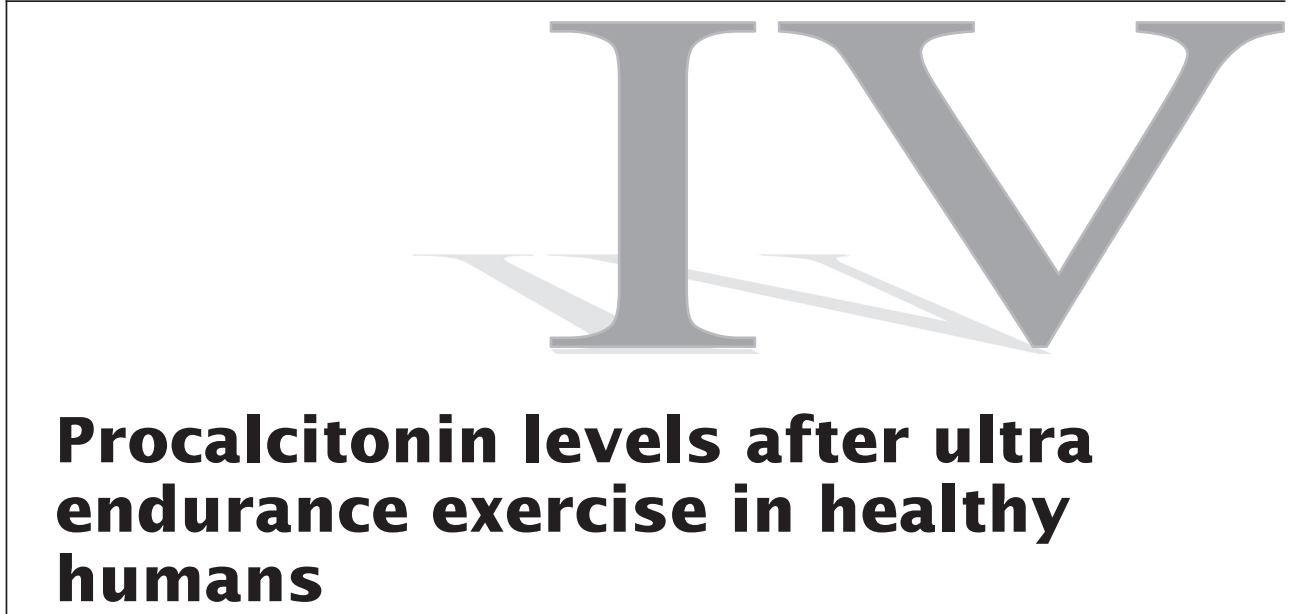

K. Joop, A.E. Jeukendrup, A.J.M. Wagenmaker, R. Nieuwland, A. Sturk

Contents chapter IV

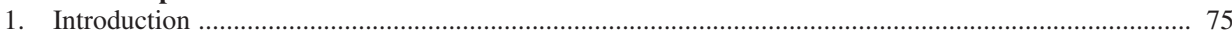

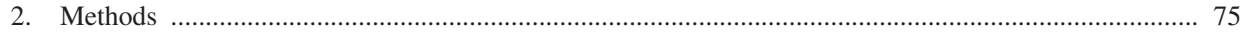

2.1 Athletes …… 75

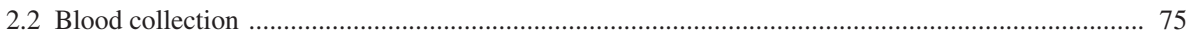

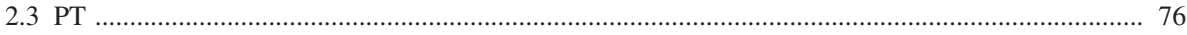

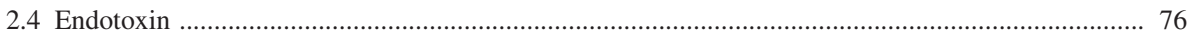

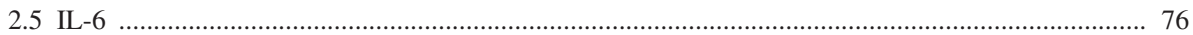

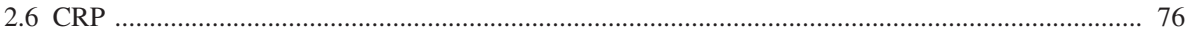

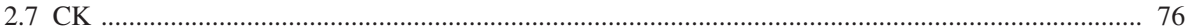

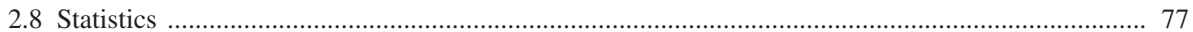

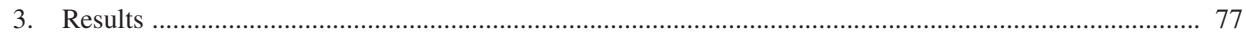

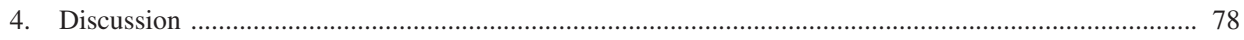

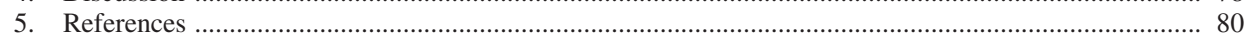




\begin{abstract}
Previously, we investigated whether gastro-intestinal (GI) complaints during an ultra endurance exercise, the Embrun Ironman triathlon, are related to gut ischemia-induced leakage of endotoxins into the circulation. We observed a mild endotoxemia and muscle damage ${ }^{13}$.

Recently, procalcitonin was found in high concentrations in patients with bacterial infection or sepsis, and at lower concentrations in non-infectious conditions. The aim of the present study was to determine procalcitonin levels before and after the ultra endurance exercise, and to determine whether changes were due to the release of endotoxins. From 30 athletes venous blood samples were collected before and at various time intervals after the exercise. Plasma procalcitonin concentrations before the exercise were low, increased approximately 4-fold after the exercise $(\mathrm{p}<0.01)$ and did not correlate with endotoxin levels $(r=0.10 ; p=0.61)$. The significantly increased plasma concentrations of creatine kinase also did not correlate with the procalcitonin increases $(\mathrm{r}=0.30, \mathrm{p}=0.11)$. The procalcitonin concentrations correlated with interleukin 6 levels (IL-6, r=0.49) and the acute phase reactant C-reactive protein (CRP, r=0.35), which was statistically significant for IL-6 but not for CRP ( $p<0.01$ and $p=0.06$, respectively).
\end{abstract}

We conclude that during and after ultra endurance exercise the rise in procalcitonin is not likely to be induced by the endotoxemia, or muscle damage. The exercise-induced cytokine alterations are likely to be responsible for the mildly increased levels of procalcitonin. 


\section{Introduction}

Endotoxins are constituents of the gram negative bacterial cell wall. Endotoxins are released from the bacteria and then trigger the immunologic response ${ }^{7}$. Elevated levels of endotoxin in the circulation cause symptoms such as fever, shivering, dizziness, nausea and various gastro-intestinal (GI) complaints $^{28}$. These symptoms are also frequently observed in ultra endurance athletes during and after their extreme exercise ${ }^{23}$. In an earlier study, we hypothesized that GI-complaints in athletes are caused by leakage of endotoxin due to gut ischemia ${ }^{6 ; 23}$. Therefore, we determined concentrations of endotoxin in blood samples collected from athletes before and after a long-distance triathlon. Almost all athletes suffered from GI-complaints during and after the triathlon, and 74\% had mild endotoxemia after the ultra endurance exercise. Although endotoxin evidently entered the circulation, no correlations were found with the observed cytokine- and acute phase responses after the triathlon.

Procalcitonin (PCT) gained much interest as a potential marker for systemic infection. PCT is a $13 \mathrm{kDa}$ polypeptide of 116 amino acids, which is the precursor of calcitonin ${ }^{14}$. Injection of endotoxin into healthy individuals increased the PCT concentrations from $<0.1 \mathrm{ng} / \mathrm{ml}$ to $5 \mathrm{ng} / \mathrm{ml}$ within 24 hours $^{1}$. Elevated PCT levels were more sensitive and specific than C-reactive protein (CRP) or interleukin 6 (IL-6) for differentiation between bacterial and viral infections 9;10;12;17;20;21 . Boeken and colleagues found that elevated concentrations of PCT could distinguish between SIRS (systemic inflammatory response syndrome) and sepsis ${ }^{5}$. In contrast to CRP no elevated levels of PCT were found in patients with trauma and without infections ${ }^{8 ; 19 ; 29}$. The function of the PCT increase is still unknown, since no subsequent rise in plasma calcitonin antigen levels or activity are observed ${ }^{24}$.

To further characterize the systemic inflammatory response of these athletes, concentrations of PCT were determined and correlations were established with endotoxin, cytokines and acute phase responses, and muscle damage.

\section{Methods}

\subsection{Athletes}

Twenty-nine males and 1 female were recruited for this study. All subjects were instructed, informed and signed consent form. Subjects aged $33.0 \pm 6.0$ years. The subjects particated in the Ironman Distance Triathlon in Embrun (1996). Four athletes abandoned the race and data from one subject were deleted because of incomplete data collection.

\subsection{Blood collection}

Blood samples were collected the day before the triathlon, immediately after the finish and 1 , 2 and 15-20 hours thereafter. At each time point blood was collected and prepared as described previously ${ }^{13}$. 


\subsection{PCT}

PCT was determined as described by Assicot et al. ${ }^{4}$ with the LUMI test PCT; BRAHMS Diagnostica, Berlin, Germany) $)^{4}$. In brief, $20 \mu \mathrm{L}$ of plasma (or standards or controls) were mixed with $250 \mu \mathrm{L}$ luminescent-labeled antibody in precoated tubes and incubated for 2 hours at room temperature on an orbital shaker (170-300 rotations per minute). The tubes were washed four times with $1 \mathrm{ml}$ washing solution. Luminescence was determined in a luminometer (Lumat LB 9507; BG \& G Berthold, Bad Wildbad, Germany) after injection of $300 \mu \mathrm{L}$ buffer plus enhancer. The lower detection limit is $0.1 \mathrm{ng} / \mathrm{ml}$. Inter-assay and intra-assay variation coefficients at low and high PCT concentrations were $10 \%$ and $6 \%$, respectively. The mean plasma PCT levels of healthy adult subjects was $0.2 \mathrm{ng} / \mathrm{ml}(\mathrm{n}=7, \mathrm{SD} 0.02)$.

\subsection{Endotoxin}

Endotoxin was determined by chromogenic assay from Boehringer Ingelheim Whittaker (Verviers, France) ${ }^{26}$. Briefly, PRP samples were thawed for 5 minutes at $37^{\circ} \mathrm{C}$ and then diluted 10 -fold with pyrogen-free water (NPBI, Emmen, The Netherlands) and heated for 15 minutes at $75^{\circ} \mathrm{C}$. This diluted and heated PRP was kept at ambient temperature for 1 hour. From this suspension, $50 \mu \mathrm{L}$ samples were transferred to a 96-wells microtiterplate (type 655161 Greiner GmbH, Frigkenhausen, Germany). After 30 minutes incubation with $50 \mu \mathrm{L}$ Limulus amoebocyte lysate at $37^{\circ} \mathrm{C}$ and subsequent incubation with chromogenic substrate for 6 minutes, the reactions were stopped by addition of $100 \mu \mathrm{L}$ acetic acid (20\%). The optical density was determined at $\lambda=405 \mathrm{~nm}$ (Spectra Max 250, Molecular Devices, Sunnyvale, Ca, USA). With the standard provided by the manufacture, $1.2 \mathrm{EU} / \mathrm{ml}$ corresponds to $120 \mathrm{pg} / \mathrm{ml}$ endotoxin.

\subsection{IL-6}

Serum IL-6 concentrations were determined by ELISA (IL-6 Pelikine Compact ${ }^{\mathrm{TM}}$ ELISA kits; Central Laboratory of the Netherlands Red Cross Blood Transfusion Service Amsterdam; The Netherlands).

\subsection{CRP}

Plasma CRP concentrations were determined by nephelometry (Hitachi 911 analyzer, Boehringer Mannheim, Mannheim, Germany) with reagents and according to the instructions supplied by this manufacturer.

\subsection{CK}

Creatine kinase (CK) was determined by spectrophotometry on a Hitachi 747 analyser (Boehringer Mannheim, Mannheim, Germany) with the N-acetylcystine-activated CK reagent kit and according to the instructions provided by this manufacturer. 


\subsection{Statistics}

Statistical analyses were performed using nonparametric Spearman's rho correlations (Nonparametric test was used to correct for skewed distribution), and one way ANOVA (Post Hoc Test Bonferroni; SPSS 8.0; SPSS Inc., Chicago, Ill). Since the kinetics of PCT, endotoxin and cytokine- and acute phase proteins are different, maximum response values were compared.

\section{Results}

Figure 1 shows the concentrations of PCT before and after the triathlon. Before the triathlon, the PCT levels were low (median $0.2 \mathrm{ng} / \mathrm{ml}$; range $0.1-0.5$ ). Already immediately after the exercise, the concentrations of PCT had increased to $0.9 \mathrm{ng} / \mathrm{ml}$ (range 0.3-4.8; $\mathrm{p}<0.01$ ). No further statistically significant increases were observed, although the median level of PCT after 16 hours was about 1.5 higher (median $1.4 \mathrm{ng} / \mathrm{ml}$; range 0.2-6.4) than immediately after the triathlon.

Lines represent median with range (minimum-maximum). PCT concentrations immediately after exercise were significantly elevated compared to the PCT levels before exercise. $(p<0.01)$, but did not increase significantly further after the race.

To determine whether the increases in PCT levels are due to leakage of endotoxin into the circulation, the highest PCT levels were correlated to the highest concentrations of endotoxin (Figure 2A). No correlation was found $(\mathrm{r}=0.10, \mathrm{p}=0.61)$.

Correlations were present between the highest PCT concentrations and highest concentrations of IL-6 ( $r=0.49$; $p<0.01$; Figure 2B). A correlation was also found between the highest PCT concentrations and the highest CRP concentrations ( $\mathrm{r}=0.35)$, but this did not reach statistical significance $(\mathrm{p}=0.06)$ (Figure $2 \mathrm{C}$ ).

Figure 1. Plasma PCT concentrations in highly trained athletes $(n=30)$ before and after ultra endurance exercise

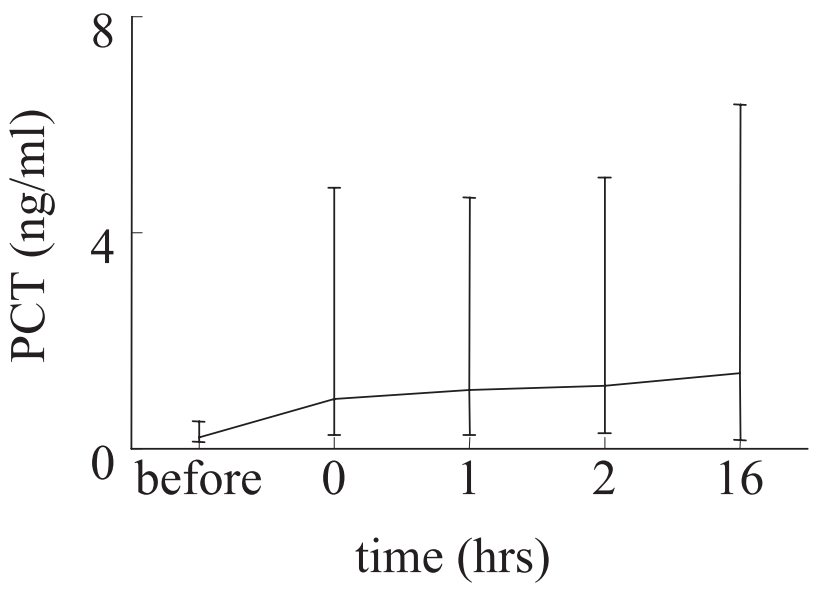



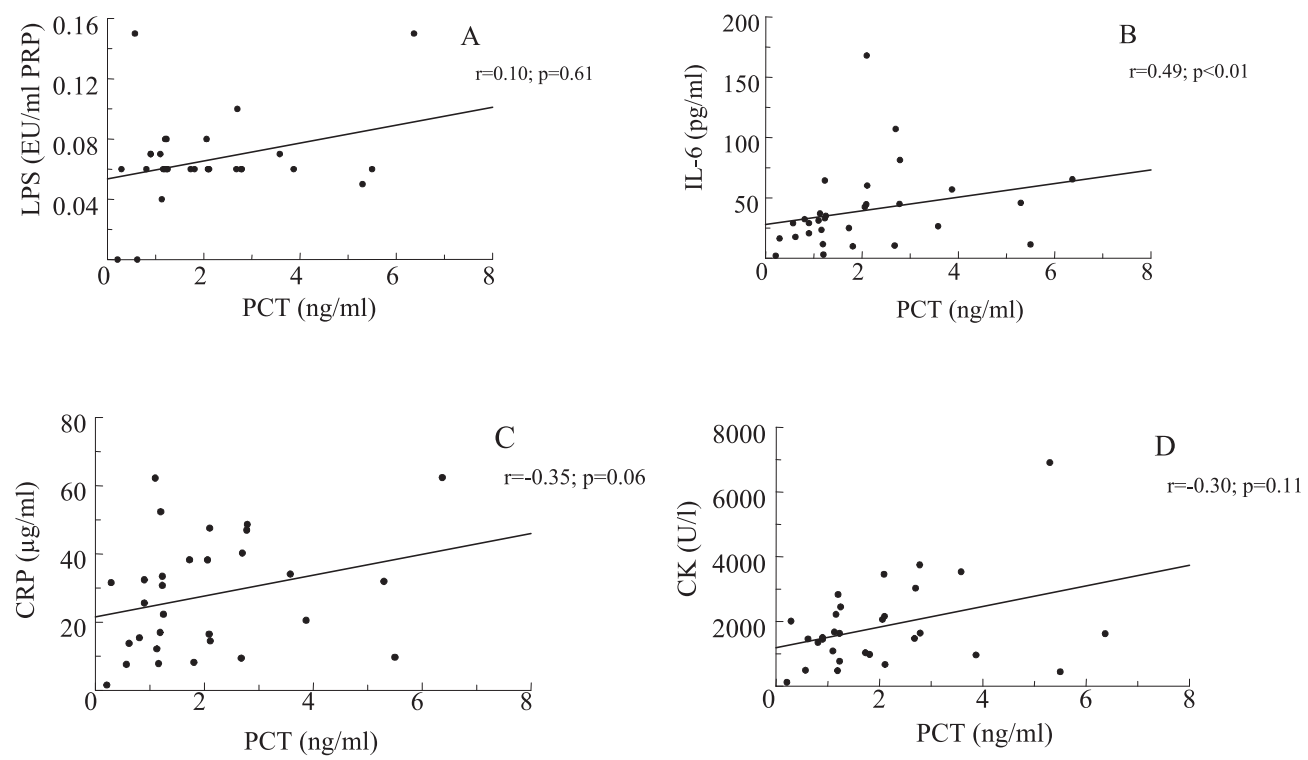

Figure 2. Correlations of the maximum values of PCT levels compared with maximum values of endotoxin (Figure 2A), IL 6 (Figure 2B), CRP (Figure 2C) and CK (Figure 2D).

No correlation could be determined between the maximum levels of CK and PCT $(r=0.30$ $\mathrm{p}=0.11$, figure 2D).

\section{Discussion}

Severe generalized bacterial infections with systemic manifestation are associated with increased concentrations of $\mathrm{PCT}^{11 ; 15}$. For example, in children without infection PCT levels were very low $(<0.1 \mathrm{ng} / \mathrm{ml})$, they were very high in those with severe bacterial infections $(6-53 \mathrm{ng} / \mathrm{ml})$ and only moderately increased by inflammatory response of non-infectious origin $(0.3-1.5 \mathrm{ng} / \mathrm{ml})^{4}$. For adults similar data have been obtained ${ }^{1}$. Moulin and coworkers found that a low threshold of 1 $\mathrm{ng} / \mathrm{ml}$ PCT was more sensitive, specific and had greater positive- and negative predictive values than CRP or IL-6 for differentiating bacterial and viral causes of community pneumonia ${ }^{2 ; 17 ; 20 ; 21}$.

In the present study we measured concentrations of PCT in athletes and determined whether or not changes in PCT paralleled the observed increase in endotoxin levels. Immediately after the exercise the levels of PCT increased 4-fold compared to the levels before exercise, but these changes did not correlate to the observed increase in endotoxin levels.

Immediately after the race the athletes showed five-fold increased CK levels and after some 16 hours the $\mathrm{CK}$ levels had increased nine-fold. This illustrates the muscle damage due to the

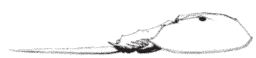


exercise $^{13}$. However, no correlation was found between the highest PCT and the highest CK levels, indicating the PCT response to be unlikely due to the muscle damage.

In the present study the PCT levels ranged between 0.3-6.4 ng/ml after exercise. These concentrations are comparable to those found in polytrauma patients $(<0.5-10 \mathrm{ng} / \mathrm{ml})$, i.e. patients without infection, and in post-operative patients ${ }^{3 ; 18 ; 22 ; 27}$.

It was found that SIRS triggered by a cardiac surgical procedure caused a moderate and transient increase in PCT levels on the first post-operative day ${ }^{2 ; 3}$. Also it was found that patients with perioperative myocardial infarction and undergoing cardiac surgery developed high levels of $\mathrm{PCT}^{16}$. Not only cardiac surgery but also oesophagectomies gave post-operative increased levels of $\mathrm{PCT}^{27}$. Therefore it may concluded that in early postoperative periods elevated levels of PCT should be interpreted with caution regarding infection diagnosis. Also, no additional value was found for PCT to differentiate between mild and severe pancreatitis ${ }^{22}$.

Somech and coworkers report a highly significant correlation between PCT and CRP in diverse clinical conditions. They concluded that PCT is in part an acute phase reactant ${ }^{25}$. Evidently in these athletes there was a correlation between PCT and CRP $(r=0.35)$ albeit just not significant $(\mathrm{p}=0.06)$.

From the present study we conclude that the endotoxin entering the circulation of these athletes, or their muscle damage, are unlikely to be the cause of the observed PCT increases. Instead, we propose the acute phase response as triggered by IL- 6 and reflected by CRP increases, to be responsible for the PCT increase. 


\section{References}

1 Al-Nawas B., Krammer I., Shah P.M. Procalcitonin in diagnosis of severe infections. Eur J Med Res 1996; 1:331-333.

2 Aouifi A., Piriou V., Bastien O., Blanc P., Bouvier H., Evans R., Célard M., Vandenesch F., Rousson R., Lehot J.J. Usefulness of procalcitonin for diagnosis of infection in cardiac surgical patients. Crit Care Med 2000; 28:3171-3176.

3 Aouifi A., Piriou V., Blanc P., Bouvier H., Bastien O., Chiari P., Rousson R., Evans R., Lehot J.J. Effect of cardiopulmonary bypass on serum procalcitonin and $\mathrm{C}$-reactive protein concentrations. Br J Anaesth 1999; 83:602-607.

4 Assicot M., Gendrel D., Carsin H., Raymond J., Guilbaud J., Bohuon C. High serum procalcitonin concentrations in patients with sepsis and infection. Lancet 1993; 341:515-518.

5 Boeken U., Feindt P., Micek M., Petzold T., Schulte H.D., Gams E. Procalcitonin (PCT) in cardiac surgery: diagnostic value in systemic inflammatory response syndrome (SIRS), sepsis and after heart transplantation (HTX). Cardio vasc Surg 2000; 8:550-554.

6 Bosenberg T., Brock-Utne J.G., Gaffin S.L., Wells M.T.B., Blake G. T. W. Strenuous exercise causes systemic endotoxemia. Am Physiol Soc 1988; 65:106-108.

7 Brade H., Brade L., Schade U., Zähringer U., Holst O., Kuhn H.M., Rozalski A., Röhrscheidt E., Rietschel E.T. Structure, endotoxicity, immunogenicity and antigenicity of bacterial lipopolysaccharides (endotoxins, O-antigens). Prog Clin Biol Res 1988; 272:17-45.

8 Dandona P., Nix D., Wilson M.F., Aljada A., Love J., Assicot M., Bohuon C. Procalcitonin increase after endotoxin injection in normal subjects. J Clin Chem Clin.Biochem 1994; 79:1605-1608.

9 Fleischhack G., Kambeck I., Cipic D., Hasan C., Bode U. Procalcitonin in paediatric cancer patients: its diagnostic relevance is superior to that of C-reactive protein, interleukin 6, interleukin 8, soluble interleukin 2 receptor and soluble tumour necrosis factor receptor II. Br J Haematol 2000; 111:10931102.

10 Gendrel D., Raymond J., Coste J., Moulin F., Lorrot M., Guérin S., Ravilly S., Lefèvre H., Royer C, Lacombe C., Palmer P., Bohuon C. Comparison of procalcitonin with C-reactive protein, interleukin 6 and interferon-alpha for differentiation of bacterial vs. viral infections. Pediatr Infect Dis J 1999; 18:875-881.

11 Gérard Y., Hober D., Petitjean S., Assicot M., Bohuon C., Mouton Y., Wattré P. High serum procalcitonin level in a 4-year-old liver transplant recipient with a disseminated candidiasis. Infection $1995 ; 23: 310-311$.

12 Hatherill M., Tibby S.M., Sykes K., Turner C., Murdoch I.A. Diagnostic markers of infection: comparison of procalcitonin with C reactive protein and leucocyte count. Arch Dis Child 1999; 81:417421.

13 Jeukendrup E., Joop K., Sturk A. Stegen J.H.J.C., Senden J., Saris W.H.M., Wagenmakers A.J.M. Relationship between gastro-intestinal complaints and endotoxemia, cytokine release and acute phase reaction during and after a long- distance triathlon in highly trained men. Clin Scien 2000; 98: 47-55.

14 Karzai W., Meier-Hellmann A., Reinhart K. Procalcitonin - An indicator of sepsis, J.-L.Vincent, Yearbook of intensive care and emergency medicine. Springer - Verlag 1998; 248-256.

15 Karzai W., Oberhoffer M., Meier-Hellmann A., Reinhart K. Procalcitonin--a new indicator of the systemic response to severe infections. Infection 1997; 25:329-334.

16 Lecharny J.B., Khater D., Bronchard R., Philip I., Durand G., Desmonts J.M., Dehoux M. Hyperprocalcitonemia in patients with perioperative myocardial infarction after cardiac surgery. Crit Care Med 2001; 29:323-325.

17 Lorrot M., Moulin F., Coste J., Ravilly S., Guérin S., Lebon P., Lacombe C., Raymond J., Bohuon C., Gendrel D. Procalcitonin in pediatric emergencies: comparison with C-reactive protein, interleukin-6 and interferon alpha in the differentiation between bacterial and viral infections. Presse Med 2000; 29:128-134. 
18 Meisner M., Tschaikowsky K., Beier W., Schuttler J. Procalcitonin (PCT) - a novel parameter for diagnosis and monitoring of bacterial inflammation and sepsis. Anasthesiologie \& Intensivmedizin 1996; 10:529-539.

19 Monneret G., Doche C., Durand D.V., Lepape A., Bienvenu J. Procalcitonin as a specific marker of bacterial infection in adults. Clin Chem Lab Med 1998; 36:67-68.

20 Moulin F., Raymond J., Lorrot M., Marc E., Coste J., Iniguez J.L., Kalifa G., Bohuon C., Gendrel D. Procalcitonin in children admitted to hospital with community acquired pneumonia. Arch Dis Child 2001; 84:332-336.

21 Müller B., Becker K.L., Schächinger H., Rickenbacher P.R., Huber P.R., Zimmerli W., Ritz R. Calcitonin precursors are reliable markers of sepsis in a medical intensive care unit. Crit Care Med 2000; 28:977-983.

22 Müller C.A., Uhl W., Printzen G., Gloor B., Bischofberger H., Tcholakov O., Büchler M.W. Role of procalcitonin and granulocyte colony stimulating factor in the early prediction of infected necrosis in severe acute pancreatitis. Gut 2000; 46:233-238.

23 Nadel E.R. Temperature regulation and prolonged exercise science. Lamb D.R., Murray R. eds. Perspectives in exercise science and sport medicine 1988; 125-151.

24 O’Neill M.E., Wilkinson M., Robinson B.G., McDowall D.B., Cooper K.A., Mihailidou A.S., Frewin D.B., Clifton-Bligh P., Hunyor S.N. The effect of exercise on circulating immunoreactive calcitonin in men. Horm Metab Res 1990; 22:546-550.

25 Somech R., Zakuth V., Assia A., Jurgenson U., Spirer Z. Procalcitonin correlates with C-reactive protein as an acute-phase reactant in pediatric patients. Isr Med Assoc J 2000; 2: 147-150.

26 Sturk A., Joop K., ten Cate J.W., Thomas L.L. Optimalization of a chromogenic assay for endotoxin in blood. Prog Clin Biol Res 1985; 189:117-137.

27 Szakmany T., Molnar Z., Koszegi T., Tekeres M. Inflammatory markers after surgical treatment of esophageal tumors. Orv Hetil 2000; 141:489-492.

28 van Deventer S.J., Buller H.R., ten Cate J.W., Sturk A., Pauw W. Endotoxemia: an early predictor of septicaemia in febrile patients. Lancet 1988; i:605-609.

29 Wanner G.A., Keel M., Steckholzer U., Beier W., Stocker R., Ertel W. Relationship between procalcitonin plasma levels and severity of injury, sepsis, organ failure, and mortality in injured patients. Crit Care Med 2000; 28:950-957. 

CHAPTER

\section{Predictive values for fatal outcome in septic patients: A comparison between the SIMPLY RED $^{\oplus}$ and the chromogenic LPS- assays}

K. Joop, J. Berkhout, P.H.P. Groeneveld, R. Nieuwland, A. Sturk

Contents chapter $\mathbf{V}$

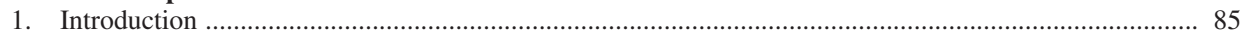

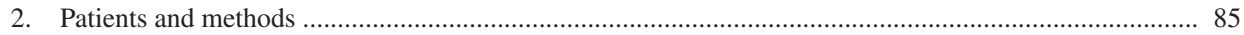

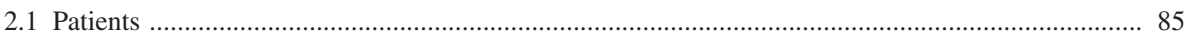

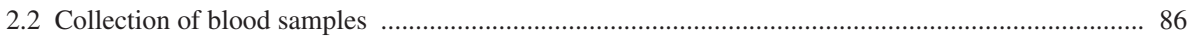

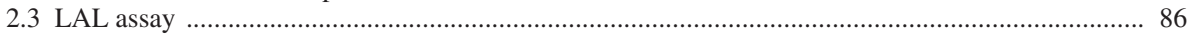

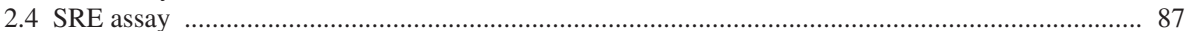

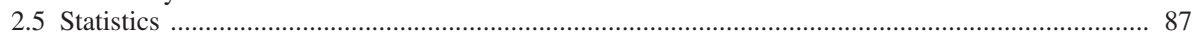

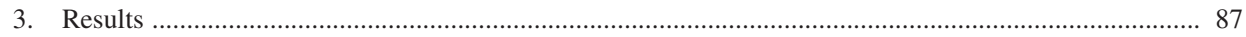

3.1 Microbiological data of the patient population ...................................................................... 87

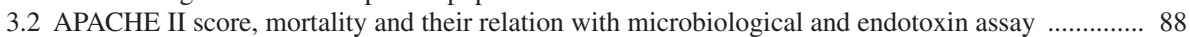

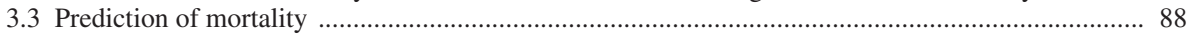

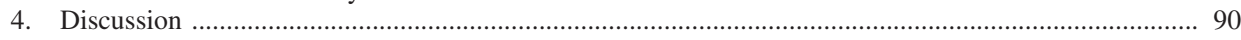

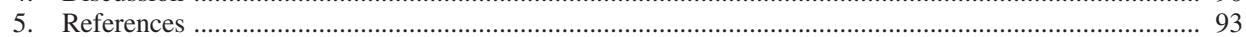




\begin{abstract}
Although the presence of endotoxin in the systemic circulation has been reported to be an important risk factor for fatal outcome, the detection of endotoxin by the regular chromogenic Limulus Amoebocyte Lysate (LAL) assay is too expensive and labour intensive to perform on only a few patient samples per day. A simple bedside test for use upon whole blood, the SIMPLY $\mathrm{RED}^{\circledR}$ Endotoxin (SRE) assay, has been reported to be of clinical value in critically ill patients. In the present study we evaluated the LAL and SRE assays for their ability to predict mortality in 74 (APACHE II score 6-31) patients clinically suspected to have sepsis. In 13 patients, sepsis could not be confirmed. Of the 61 septic patients 6 died as result of sepsis, of which one patient was positive for the LAL assay and another patient for the SRE assay. Of the 55 survivors, 5 were positive for the LAL, 12 for the SRE and 2 for both assays. Thus, the positive predictive values in all septic patients were low for both assays (13\% and 7\%, respectively), and the negative predictive values ( $91 \%$ and $89 \%$, respectively) were also considered too low to be clinically useful. If applied to the 17 patients with APACHE II score $>19$ (the 75 percentile), sensitivity and positive predictive values both increased to $17 \%-20 \%$ but specificity and negative predictive value both decreased to $58-67 \%$ for the two assays. This performance of the two endotoxin assays to predict 28 day mortality due to sepsis was similar to the results of the blood and local cultures regarding the PPV (10\%-38\%) and the NPV (80\%-100\%), but inverse for the sensitivity (80\%-100\%) and the specificity (22\%-37\%), both in the subgroup of 61 patients with sepsis and all 74 patients $(15-10 \%, 100-95 \%, 100-83 \%, 49-34 \%$, respectively). We conclude that neither the SRE nor the LAL assay is useful in predicting or excluding mortality in patients clinically suspected of having sepsis.
\end{abstract}




\section{Introduction}

Despite antibiotic treatment, there still is a high mortality in patients who develop sepsis ${ }^{7}$. When endotoxin, i.e. lipopolysaccharides (LPS) derived from the outer wall of Gram-negative bacteria, are present in the circulation of patients, the risk for fatal outcome increases ${ }^{1}$. Concentrations of endotoxin can be determined with the Limulus amoebocyte lysate assay (LAL assay) ${ }^{17}$, in which endotoxin activates the clotting cascade present in the amoebocyte of the horseshoe crab (Limulus polyphemus) and the activated enzyme(s) are measured with a chromogenic substrate. In this type of assay even low concentrations of endotoxin can be detected ( $>3 \mathrm{pg} / \mathrm{ml}$ or $0.036 \mathrm{EU} / \mathrm{ml}$ platelet rich plasma (PRP) ${ }^{16}$. This is essential because patients with even low concentrations of endotoxin, i.e. concentrations ranging between 0.06 to $0.12 \mathrm{EU}$ endotoxin/ml PRP, are already considered to have endotoxemia ${ }^{19}$. The LAL assay, however, has to be performed under sterile conditions, is relatively slow (2 hours), is technically demanding, and due to the necessity of including a standard curve with each assay, too costly to be performed on only a few patient samples per day. Nevertheless, circulation of endotoxin is still considered a risk factor for mortality and contributes to predict mortality in febrile patients who were in shock at admission ${ }^{20}$.

A rapid bedside test has been reported for the measurements of endotoxin in whole blood, the SIMPLY RED ${ }^{\circledR}$ Endotoxin (SRE) assay ${ }^{13}$. In this assay, the erythrocytes agglutinate upon the addition of blood containing endotoxin. The active agent in this assay is a chemical conjugate of a monoclonal antibody, which binds to the surface of the erythrocytes of the patient but itself does not cause agglutination, and the cyclic peptide antibiotic polymyxin B. Upon addition of blood containing endotoxin, this endotoxin binds to polymyxin B and induces the agglutination of the conjugate-coated erythrocytes. The SRE assay predicts sepsis with high specificity (90\%) in critically ill patients ${ }^{2}$. In the present study we compared the LAL and SRE assays for their ability to predict fatal outcome in a broad range of patients clinically suspected to have sepsis.

\section{Patients and Methods}

The study was performed at the Leiden University Medical Center (Leiden, The Netherlands) and was approved by the local medical ethical committee (protocol number 13/97-5/ymo/en).

\subsection{Patients}

The SIRS (systemic inflammatory response syndrome) criteria for sepsis were established according to the guidelines recommended by the American College of Chest Physicians/Society of Clinical Care Medicine Consensus Conference, $1992^{3}$. The criteria for SIRS were: (i) a temperature $>38^{\circ} \mathrm{C}$ or $<36^{\circ} \mathrm{C}$; (ii) a heart rate $>90$ beats/minute; (iii) tachypnea (respiratory rate $>20$ breaths $/$ minute or $\mathrm{PaCO}_{2}<32 \mathrm{~mm} \mathrm{Hg}$ ); and (iv) a white blood cell count $>12 \times 10^{9} / \mathrm{L}$ or $<4 \times 10^{9} / \mathrm{L}$; or the presence of $>10 \%$ immature neutrophils. These changes should represent an 
acute alteration from baseline in the absence of other known causes for such abnormalities, such as chemotherapy-induced neutropenia or leukopenia. Sepsis was established if patients fulfilled two or more of the criteria for SIRS and had a positive blood and/or local culture.

Seventy-four consecutive patients (46 men and 28 women; median age 60 years (range 16-90)) were included in the study at the moment that they were clinically suspected to have sepsis by their attending physician and fulfilled the SIRS criteria. Thus, from the 74 patients blood was taken the day they were admitted to the hospital in $23 \%$ of the cases ( 1 intensive care patient), on the day after admission to the hospital in $26 \%$ ( 3 intensive care patients) and at several days after hospitalization in $51 \%$ ( 8 intensive care patients).

At 28 days after study entry, 8 patients had died. However, only 6 patients died due to the sepsis or complications thereof: 2 from the sepsis itself, 2 from the adult respiratory distress syndrome and 2 from multiple organ dysfunction syndromes. The other 2 patients died of a heart failure or at home, without it being likely that those deaths were sepsis related. We therefore calculated all efficacy parameters based upon the 6 deaths related to the sepsis.

\subsection{Collection of blood samples}

From each patient a heparin-anticoagulated (30 IU heparin final concentration, Endo Tube, Chromogenix AM, Mölndal, Sweden), a non-anticoagulated and an EDTA-anticoagulated blood sample (BD Biosciences, Franklin lakes, NJ, USA) was collected. Heparin-anticoagulated blood was immediately placed on melting ice until centrifugation $\left(10\right.$ minutes $\left.180 \mathrm{x} \mathrm{g} ; 4^{\circ} \mathrm{C}\right)$ to prepare PRP. Immediately before centrifugation, $30 \mu \mathrm{l}$ of the heparin-anticoagulated blood was removed and used for the SRE assay. The other blood samples were used for routine assays. Aliquots of PRP were stored frozen at $-70^{\circ} \mathrm{C}$ prior to the LAL assay. In the instructions provided by the manufacturer EDTA is proposed as the anticoagulant to be used in the SRE assay. However, at the start of the study the manufacturer informed us that heparin can also be used. We then decided to use the heparinized blood for both assays, to exclude contamination of the EDTA tube as a source of possible discrepancy between the LAL and SRE assays.

\subsection{LAL assay}

The LAL assay was obtained from Boehringer Ingelheim Whittaker (Verviers, France). Briefly, PRP samples were thawed for 5 minutes at $37^{\circ} \mathrm{C}$, diluted 10 -fold with pyrogen-free water (NPBI, Emmen, The Netherlands) and then heated for 15 minutes at $75^{\circ} \mathrm{C}$. Subsequently, PRP was kept at ambient temperature for 1 hour. From this suspension, $50 \mu \mathrm{l}$ samples were transferred to 96-well microtiterplates (type 655161 Greiner GmbH, Frigkenhausen, ger). After 30 minutes incubation with $50 \mu 1 \mathrm{LAL}$ at $37^{\circ} \mathrm{C}$ and subsequent incubation with chromogenic substrate for 6 minutes, the reactions were stopped by addition of $100 \mu 1$ acetic acid (20\%). The optical density was determined at $\lambda=405 \mathrm{~nm}$ (Spectra Max 250, Molecular Devices, Sunnyvale, CA, USA). With the standard (Escherichia Coli; 0111:B4) provided by the manufacturer, $1.2 \mathrm{EU} / \mathrm{ml}$ 
corresponds to $120 \mathrm{pg} / \mathrm{ml}$ endotoxin. The detection limit of this assay is $0.036 \mathrm{EU} / \mathrm{ml} \mathrm{PRP}{ }^{17}$. The LAL used in this assay is not sensitive to (1.3)- $\beta$-D-glucan, i.e. fungal infections, because factor $\mathrm{G}$ has been extracted from this reagent ${ }^{8,11,12}$.

\subsection{SRE assay}

The SRE assay was obtained from Agen Biomedical Ltd. (Acacia Ridge, AUS). Ten $\mu 1$ of heparin-anticoagulated blood aliquots were pipetted in duplicate into reaction wells containing only buffer reagent (control) or test reagent. The suspensions were mixed by gently swirling for 2 minutes at ambient temperature. When visible agglutination occurred in duplicate wells, a result was considered positive. When agglutination occurred in only one well of the test reagents, the experiment was repeated. If agglutination still occurred in only one test reagent well, the outcome was considered negative. When agglutination occurred in duplicate, the outcome was scored as positive. The lower cut-off value reported by Rylatt et al. is $1.56 \mathrm{ng} / \mathrm{ml}$, but $\mathrm{Ng}$ et al. suggest $25 \mathrm{pg} / \mathrm{ml}^{2,13}$.

\subsection{Statistics}

Correlation analyses were performed using the nonparametric Spearman's rho test (SPSS 8.0; SPSS Inc., Chicago, Ill). Sensitivity was defined as the number of non-survivors that had a positive endotoxin test (true positive) divided by the total number of non-survivors. Specificity was defined as the survivors that had a negative test result (true negative) divided by all survivors. The number of non-survivors with a positive endotoxin test (true positive) divided by the total number of patients with a positive test result was designated as the positive predictive value (PPV). The negative predictive value (NPV) was calculated by dividing the number of survivors with a negative test (true negative) by the total number of patients with a negative test result.

\section{Results}

\subsection{Microbiological data of the patient population}

The results of the bacterial cultures are provided in table 1. Blood cultures were performed of 71 patients, of which 39 (55\%) had bacteremia and 30 (42\%) gram-negative sepsis. Local cultures were performed in 70 patients. Of these, $48(69 \%)$ had a positive culture and $46(66 \%)$ had a gram negative infection. The cultures originated from the urinary tract (47\%), respiratory tract/sputum (26\%) and skin/ joints, cerebrospinal fluid, gastrointestinal tract, ear and nose and throat (11\%). In 13 patients sepsis could not be confirmed since blood- and/or local cultures were negative or not performed. These patients suffered from cholangitis (5), sinusitis (1), pneumococcal pneumonia (1), focus of infection located from skin biopsy (1), excudative pleuritis (1), during chemotherapy (3) and an unknown focus for infection (1). Of the 61 septic patients, 13 patients only had a positive blood culture, 22 patients only had a positive local culture and 26 patients had both positive blood and positive local cultures. 


\subsection{APACHE II score, mortality and their relation with microbiological and endotoxin assays}

Of the 61 septic patients, 56 (92\%) had a gram negative infection based on blood- and/or local cultures (Table 1). Three patient subgroups were identified based on the 25-75 percentiles of the APACHE II score: $<11(n=9), 11-19(n=35)$ and $>19(n=17)$. For each of these subgroups, the outcome of the microbiological data, endotoxin assays and mortality are summarized (Table 2). The majority of the patients were negative in the LAL (87\%) and SRE (82\%) assays. The patients with APACHE II score $>19$ showed the highest mortality (29\%). The highest percentages of patients positive in the LAL and SRE assays were also found in this patient group (29 and 35\%, respectively), including 2 patients that were positive for both assays.

Of the total of 6 non-survivors due to the sepsis (Table 3), only one patient was positive for the LAL assay and one for the SRE assay, and 4 patients had no positive reactions in either the LAL or SRE assay. Of the 55 surviving patients, 5 were positive in the LAL assay, 12 in the SRE assay and 2 in both assays.

\subsection{Prediction of mortality}

The negative- and positive- predictive values (NPV and PPV, respectively), sensitivity and specificity were calculated for the two endotoxin-assays and compared with the values for culture results for (i) the total number of septic patients and (ii) the patients with APACHE II score $>19$ (Table 4). With the inclusion of all septic patients the NPV and specificity for the two endotoxin assays were 91\%-89\%, but both the PPV (13-7\%) and sensitivity (both 17\%) were low. When applied only to the patients with APACHE II score $>19$, the sensitivity (both 20\%) and PPV (20\%-17\%) slightly improved for both assays, but the specificity (67\%-58\%) and NPV (67-64\%) decreased. To estimate the performance of the culture results for the prediction of 28 day mortality, the data obtained in all 74 patients were calculated (Table 4), i.e. including the 13 non-septic patients. This was done because the culture result is part of the definition sepsis and thus a proper evaluation requires the analysis of the complete group of patients. Results are presented in table 4. We found for, blood and local culture NPV 100\%-95\% PPV 15\%-10\% and sensitivity $83-100 \%$, respectively, but a very low specificity, 49\%-34\%.

Table 1. The result of the blood and local cultures in all patients $(n=74)$ clinically suspected to have sepsis Blood culture

\begin{tabular}{lllllll}
\hline & Not done & Sterile & Gram-pos & Gram-neg & Gram-pos + neg & Total \\
\hline Not done & 0 & 4 & 0 & 0 & 0 & 4 \\
& 0 & 9 & 3 & 9 & 1 & 22 \\
Sterile & 0 & 0 & 2 & 0 & 0 & 2 \\
Gram-pos & 3 & 14 & 3 & 17 & 0 & 37 \\
Gram-neg & 0 & 5 & 1 & 2 & 1 & 9 \\
\hline
\end{tabular}


Table 2. Relation between the clinical status (APACHE II score), mortality, culture results and endotoxin assays of the septic patients $(\mathrm{n}=61)$

\begin{tabular}{|c|c|c|c|c|c|}
\hline \multirow{7}{*}{$\begin{array}{l}\stackrel{\Xi}{\Xi} \\
\stackrel{\Xi}{\Xi} \\
\frac{\Xi}{\Xi} \\
\frac{\Xi}{0}\end{array}$} & & & \multicolumn{3}{|c|}{ APACHE II score } \\
\hline & & & $<11(\mathrm{n}=9)$ & $11-19(n=35)$ & $>19(\mathrm{n}=17)$ \\
\hline & \multicolumn{2}{|c|}{ Sterile } & 1 & 15 & 3 \\
\hline & \multicolumn{2}{|c|}{ Gram negative } & 5 & 13 & 10 \\
\hline & \multicolumn{2}{|c|}{ Gram positive } & 1 & 6 & 2 \\
\hline & \multicolumn{2}{|c|}{ Both gram negative and positive } & 0 & 1 & 1 \\
\hline & \multicolumn{2}{|c|}{ Not done } & 2 & 0 & 1 \\
\hline & \multicolumn{2}{|c|}{ Sterile } & 3 & 5 & 5 \\
\hline 当 & \multicolumn{2}{|c|}{ Gram negative } & 5 & 24 & 8 \\
\hline $\bar{\Xi}$ & \multicolumn{2}{|c|}{ Gram positive } & 0 & 2 & 0 \\
\hline త్ & \multicolumn{2}{|c|}{ Both gram negative and positive } & 1 & 4 & 4 \\
\hline$\stackrel{9}{1}$ & \multicolumn{2}{|c|}{ Not done } & 0 & 0 & 0 \\
\hline \multirow{2}{*}{\multicolumn{2}{|c|}{ LAL assay }} & Negative $(<0.036 \mathrm{EU} / \mathrm{ml}$ PRP $)$ & 8 & 33 & 12 \\
\hline & & Positive ( $\geq 0.036 \mathrm{EU} / \mathrm{ml} \mathrm{PRP}$ ) & 1 & 2 & 5 \\
\hline \multicolumn{2}{|c|}{ SRE assay } & Negative & 7 & 31 & 12 \\
\hline & & Positive & 2 & 7 & 6 \\
\hline \multicolumn{3}{|c|}{ Mortality (28 days) } & $1 *$ & $2 *$ & 5 \\
\hline
\end{tabular}

* one patient did not die due to the sepsis in each group.

Table 3. Results of LAL and SRE assays compared with mortality (as result of sepsis) in the septic patients $(\mathrm{n}=61)$

\section{APACHE II score}

$<11 \quad>19$

\section{Non-survivors}

LAL assay positive

SRE assay positive

LAL and SRE assay positive

LAL and SRE assay negative

Subtotal

\begin{tabular}{lll}
0 & 0 & 1 \\
0 & 0 & 1 \\
0 & 0 & 0 \\
0 & 1 & 3 \\
0 & 1 & 5 \\
\hline
\end{tabular}

\section{Survivors}

LAL assay positive

SRE assay positive

LAL and SRE assay positive

LAL and SRE assay negative

Subtotal

$\begin{array}{lll}1 & 2 & 2 \\ 2 & 7 & 3 \\ 0 & 0 & 2 \\ 6 & 25 & 5 \\ 9 & 34 & 12 \\ 9 & 35 & 17\end{array}$

Total 
Table 4. The positive predictive value (PPV), negative predictive value (NPV), sensitivity and specificity for endotoxin assays and culture results in all septic patients (score 6-31), in the

septic patients with APACHE II score $>19$ and in all included patients.

\begin{tabular}{|c|c|c|c|c|c|}
\hline & & MORTAI & FOR SEPS & 8 days) & \\
\hline & & NPV $(\%)$ & PPV (\%) & Sensitivity (\%) & Specificity (\%) \\
\hline LAL assay & $\cong$ & 91 & 13 & 17 & 87 \\
\hline SRE assay & 胥 & 89 & 7 & 17 & 75 \\
\hline Locale culture & 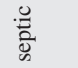 & 92 & 10 & 83 & 22 \\
\hline Blood culture & $\bar{\varepsilon}$ & 100 & 15 & 100 & 37 \\
\hline LAL assay & & 67 & 20 & 20 & 67 \\
\hline SRE assay & $\stackrel{\mathscr{0}}{\stackrel{\Perp}{\Xi}}$ & 64 & 17 & 20 & 58 \\
\hline Locale culture & है & 80 & 33 & 80 & 33 \\
\hline Blood culture & ळे हे & 100 & 38 & 100 & 27 \\
\hline Locale culture $(n=70)$ & さ气 & 95 & 10 & 83 & 34 \\
\hline Blood culture $(\mathrm{n}=71)$ & 娄 & 100 & 15 & 100 & 49 \\
\hline
\end{tabular}

\section{Discussion}

Although endotoxin plays an important role in the pathophysiology of the sepsis syndrome and multiple organ dysfunction syndromes, several difficulties have limited its measurement in clinical practice thus far. Danner et al. have demonstrated that endotoxemia was present in $43 \%$ of the 100 septic shock patients admitted to the intensive care unit and suggested that endotoxin was an important mediator of septic shock ${ }^{5}$. Moreover, we have reported that of the febrile patients who were in shock on admission to our hospital, $71 \%$ of the non-survivors had endotoxemia ${ }^{20}$. These data suggest that measurements of endotoxin might help to identify patients at risk for mortality who require additional treatment at an early stage. In the present study we compared the classical chromogenic LAL assay and a bedside test for whole blood, the SRE assay, for their ability to predict fatal outcome in a broad range of patients that were clinically suspected to have sepsis.

In the present study 74 patients suspected of sepsis were included and $13(18 \%)$ had no proven sepsis, 23 (31\%) had detectable levels of endotoxin (with the LAL and/or SRE assay), and our (28 day) mortality rate was 8 (13\%). In comparison, in one of the first clinical studies using the LAL assay, Levin et al. ${ }^{10}$ showed that of 218 patients, 39 (14\%) patients had detectable endotoxin levels and $18(8 \%)$ had no positive culture. The mortality rate in this study was 52 (24\%). We found a lower mortality rate and more patients with detectable endotoxin levels, which may be caused by different detection limits of the assays used in those two studies, i.e., $0.5 \mathrm{ng} / \mathrm{ml}$ (Levin et al.) and $3 \mathrm{pg} / \mathrm{ml}$ (our LAL assay) ${ }^{10 ; 17}$. However, leaving out the SRE positive 
patients and considering only the positive LAL patients in our study (8 i.e.11\%), the findings are comparable, which could indicate false positive SRE assay results. Rylatt et al. found that samples from healthy donors of the Brisbane blood bank gave $10 \%$ false positive SRE tests ${ }^{13}$. They also found $8 \%$ false positive SRE results in healthy laboratory personnel. This trend is confirmed by culture results in our patients. All patients who had a positive LAL assay also had a positive (gram negative) blood culture. In contrast, 7 of the 15 patients that were positive in the SRE assay had a sterile blood culture. Thus, there is no clear correlation between the SRE assay and (gram negative) bacteremia.

Our conclusion that the SRE assay provides false positive results contrasts those by $\mathrm{Ng}$ et al., who compared the LAL and SRE assays for their ability to predict systemic gram negative infection in 73 critically ill patients, and who also determined 50 healthy blood donors. The authors found no positive SRE in the healthy donors, and a much higher incidence of positive LAL and SRE assays, $47 \%$ and $49 \%$, respectively and positive culture results $(67 \%)^{13}$. The patient population under investigation by $\mathrm{Ng}$ et al. may possibly explain the different findings in that study. Only patients were included that were admitted to the intensive care unit, in contrast to the patient group in our study, of which 12 patients were admitted to the intensive care and 49 were not, so our group of patients was in general less ill².

Kollef and Eisenberg demonstrated in intensive care patients (APACHE II score 8-32), that the SRE assay predicted the development of multiple organ dysfunction syndrome but the LAL assay did not ${ }^{9}$. They performed the endotoxin assay daily and found a significant predictive value on day 2 after admission to the intensive care unit. In agreement with our findings they reported that the SRE assay could not predict hospital mortality.

From the paper of Brandzaeg and Taveira it became clear that longitudinal measurement of endotoxin (using the LAL assay) gives a higher percentage of patients with detectable endotoxin levels than single measurements ${ }^{4,18}$. However, Taveira ${ }^{18}$ found that after intravenous endotoxin injection detectable endotoxin levels were measured in only $50 \%$ of the tested individuals. Apparently, rapid clearance of endotoxin from the circulation had occurred and was not caused by insufficient sampling. In the study of Shenep et al. patients were sampled 7 times and thus, from the 26 patients clinically suspected to have sepsis 10 (38\%) had detectable levels of endotoxin and $3(14 \%)$ died ${ }^{14,4,18}$. Compared to Shenep et al. we have found a similar percentage of endotoxin positive samples (31\%), although we sampled only once.

The percentage of endotoxin positive samples is also similar to the findings of Smith et al. ${ }^{15}$, who also compared the incidence of endotoxemia in gram negative bacteremia over the last years and found a range of 43\%-90\%, when endotoxin measurements were taken 11 times over 72 hours ${ }^{15}$. 
Our finding that several samples were positive in the LAL but not the SRE test is likely to be explained by the difference in reported sensitivity of the two assays. We previously determined a cut-off level for endotoxemia of 0.06-0.12 EU endotoxin/ml PRP (5-10 pg/ml with the endotoxin standard used) for the LAL assay ${ }^{19,17}$. Such data are not available for the SRE assay, which only provides an estimate of the endotoxin concentration by the extent of agglutination (according to the literature $1.56 \mathrm{ng} / \mathrm{ml}^{13}$ or $25 \mathrm{pg} / \mathrm{ml}^{2}$ ). One of our aims in the present study was to investigate at which endotoxin concentration, determined by the LAL assay, the SRE assay would become positive. In view of the small overlap in positive LAL and SRE assays, this aim could not be fulfilled. Only 2 of 15 patients with a positive SRE test had a positive LAL assay result. This may be due to false positive SRE assays or false negative LAL assay results.

Although the SRE assay was easy to perform practically, its interpretation was cumbersome, i.e. agglutination was sometimes hardly visible, and one patient, who had an extremely high endotoxin concentration in the blood (44.8 pg endotoxin/ml PRP), was negative in the SRE assay. At present we cannot exclude that high levels of endotoxin may block the erythrocyteagglutination in the SRE assay (high-dose hook effect). Of course, we can also not exclude the possibility that the high LAL test result is due to a contamination occurring at the stage of the heating and dilution step of the PRP in the LAL assay.

Of the 61 patients with sepsis in this study 30 (42\%) had gram negative bacteremia, of which $13(43 \%)$ had detectable levels of endotoxin with either the SRE or the LAL assay (including 2 patients with both assays positive). Our study population was heterogeneous, with an APACHE II score of (ranging from 6-31). Comparing the PPV, NPV, sensitivity, and specificity from the culture results and the endotoxin assays, the cultures are more sensitive but less specific in predicting mortality.

In summary, based upon the sensitivity of $7-13 \%$ and the specificity of $75-87 \%$, we conclude that neither the LAL nor SRE assay are useful in predicting or excluding mortality in a broad range of patients known to have sepsis according to the definition of Bone ${ }^{3}$. 


\section{References}

1 From the Centers for Disease Control. Increase in National Hospital Discharge Survey rates for septicemia--United States, 1979-1987. JAMA 1990; 263: 937-938.

2 Ng K.P., Bhanumathy M., Ong G.S.Y., Yong B.H., Parasakthi N., Koh M.T., Siow C.P., Bosco J.. Endotoxin test in patients with sepsis. J Endotox Res 1995; 2:387-393.

3 Bone R.C., Balk R.A., Cerra F.B., Dellinger R.P., Fein A.M., Knaus W.A., Schein R.M., Sibbald W.J. Definitions for sepsis and organ failure and guidelines for the use of innovative therapies in sepsis. The ACCP/SCCM Consensus Conference Committee. American College of Chest Physicians/Society of Crit Care Med Chest 1992; 101:1644-1655.

4 Brandtzaeg P., Kierulf P., Gaustad P., Skulberg A., Bruun J.N., Halvorsen S., Sørensen E. Plasma endotoxin as a predictor of multiple organ failure and death in systemic meningococcal disease. J infect Dis 1989; 159:195-204.

5 Danner R.L., Elin R.J., Hosseini J.M, Wesley R.A., Reilly J.M., Parillo J.E. Endotoxemia in human septic shock. Chest 1991; 99:169-175.

6 Freeman B.D., Danner R.L., Banks S.M., Natanson C. Safeguarding patients in clinical trials with high mortality rates. Am J Respir Crit Care Med. 2001; 164:190-192.

7 Hurley J.C. Antibiotic-induced release of endotoxin. A therapeutic paradox. Drug Saf 1995; 12:183-195.

8 Iwanaga S. The limulus clotting reaction. Curr Opin Immuno. 1993; 5:74-82.

9 Kollef M.H., Eisenberg P.R. A rapid qualitative assay to detect circulating endotoxin can predict the development of multiorgan dysfunction. Chest 1997; 112:173-180.

10 Levin J., Poore T.E., Young N.S., Margolis S., Zauber N.P., Townes A.S., Bell W.R. Gram-negative sepsis: detection of endotoxemia with the limulus test. With studies of associated changes in blood coagulation, serum lipids, and complement. Ann Intern Med 1972; 76:1-7.

11 Miyazaki T., Kohno S., Mitsutake K., Yamada H., Yasuoka A., Maesaki S., Kaku M., Koga H., Hara K. Combination of conventional and endotoxin-specific limulus tests for measurement of polysaccharides in sera of rabbits with experimental systemic candidiasis. Tohoku J Exp Med. 1992; 168:1-9.

12 Novitsky T.J. Limulus amebocyte lysate (LAL) detection of endotoxin in human blood. J Endotox Res $1994 ; 1: 253-263$.

13 Rylatt D., Wilson K., Kemp B.E., Elms M.J., Manickavasagam B., Shi W., Cox A., McArthur M.J., O’Hara J., Corbett M., Bundesen P.G., Ng K.P., Ong G., Smith N., Hillyard C.J. A rapid test for endotoxin in whole blood. Prog Clin Biol Res 1995; 392:273-284.

14 Shenep J.L., Flynn P.M., Barrett F.F., Stidham G.L, Westenkirchner D.F. Serial quantitation of endotoxemia and bacteremia during therapy for gram-negative bacterial sepsis. J Infect Dis 1988; 157:565-568.

15 Smith C.R., Straube R.C., Ziegler E.J. HA-1A. A human monoclonal antibody for the treatment of gram-negative sepsis. Infect Dis Clin North Am 1992; 6:253-266.

16 Sturk A., Janssen M.E., Muylaert F.R., Joop K., Thomas L.L., ten Cate J.W. Endotoxin testing in blood. Prog Clin Biol Res 1987; 231:371-385.

17 Sturk A., Joop K., ten Cate J.W., Thomas L.L. Optimalization of a chromogenic assay for endotoxin in blood. Prog Clin Biol Res 1985; 189:117-137.

18 Taveira da Silva A.M., Kaulbach H.C., Chuidian F.S., Lambert D.R., Suffredini A.F., Danner R.L. Brief report: shock and multiple-organ dysfunction after self- administration of Salmonella endotoxin. N Engl J Med 1993; 328:1457-1460.

19 van Deventer S.J., Buller H.R., ten Cate J.W., Sturk A., Pauw W. Endotoxemia: an early predictor of septicaemia in febrile patients. Lancet 1988; i:605-609.

20 van Langevelde P., Joop K., van Loon J., Frölich M., Groeneveld P.H.P., Westendorp R.G., van Dissel J.T. Endotoxin, Cytokines, and Procalcitonin in Febrile Patients Admitted to the Hospital: Identification of Subjects at High Risk of Mortality. Clin Infect Dis. 2000; 31:1343-1348. 



\section{CHAPTER}

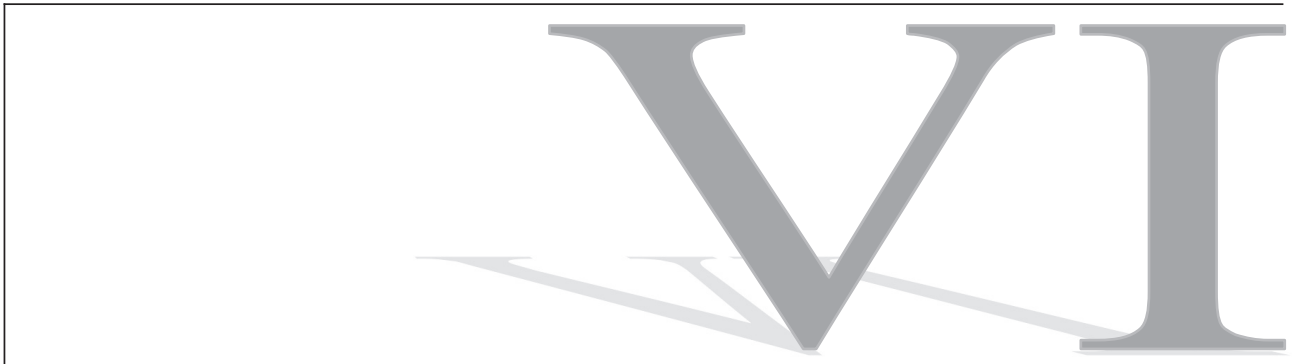

\section{Endotoxin, cytokines and}

procalcitonin in febrile patients admitted to hospital: identification of subjects with high mortality risk

K. Joop, P. van Langevelde, J. van Loon, M. Frölich, P.H.P. Groeneveld, R.G.J. Westendorp, J.T. van Dissel

\section{Contents chapter VI}

1. Introduction ...........

2. Methods

2.1 Endotoxin, cytokines (IL-6, TNF-alpha, IL-10) and procalcitonin assays ................................... 98

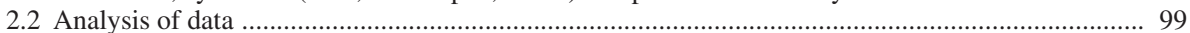

3. Results

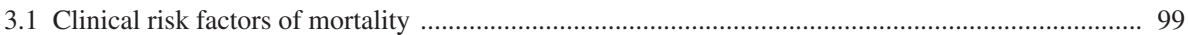

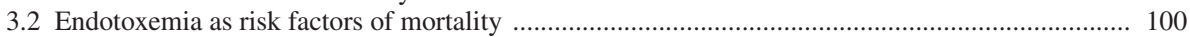

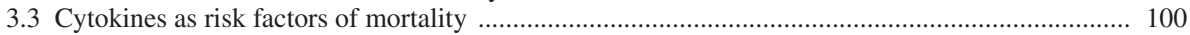

3.4 Procalcitonin as risk factor of mortality ....................................................................... 100

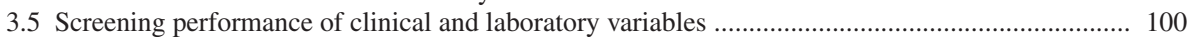

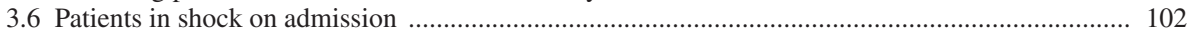

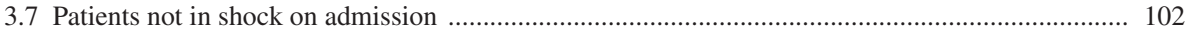

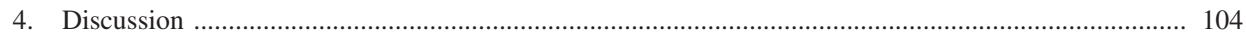

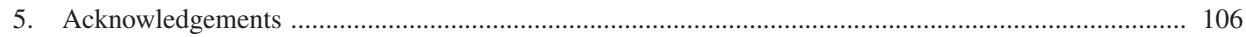

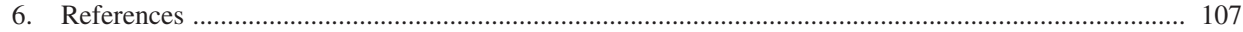




\begin{abstract}
Endotoxemia, cytokinemia and elevated levels of procalcitonin are considered risk factors for a complicated course in patients with an infection. However, the efficacy of determining these factors on admission to identify patients with a community-acquired infection who are at risk for an adverse outcome and may benefit from early preventive measures is not known. We examined prospectively in febrile patients admitted to the Medical Emergency Department of a 800 -bed academic medical center the relation between clinical data, levels of plasma endotoxin, TNF-alpha, IL-6, IL-10 and procalcitonin, and outcome. We included 464 consecutive patients (median 61 year, range 18-97, 59\% male). Blood cultures were positive in 90 (19\%) patients; more than $85 \%$ of all patients were febrile due to infection. In 345 patients no underlying illness was present, whereas 97 had an ultimately fatal disease and 22 a rapidly fatal disease. Predictors of in-hospital death were identified through unvaried and multivariate logistic regression using clinical data (age, underlying disease, duration of fever, chills, shock on admission), and plasma endotoxin, cytokines and procalcitonin.
\end{abstract}

Thirty-three patients (7.1\%) died. The mortality rate was 4.6-fold (95\% CI: 1.8-12) higher in 31 patients who were in shock on admission (7 nonsurvivors). In these patients with shock, the strongest association with mortality was the endotoxin concentration (endotoxin $5 \mathrm{pg} / \mathrm{ml}, \mathrm{RR}$ 13.7, 95\% CI: 1.4-136) that identified 5 of the 7 nonsurvivors (i.e., over 70\%) at the cost of a 5\% false-positive rate. In 433 patients not in shock on admission, a high relative risk of mortality was associated with age, underlying disease, and to a lesser degree, IL-6 and procalcitonin. In these patients without shock on admission, clinical data alone identified up to $30 \%$ of the nonsurvivors, whereas the additional measurement of IL-6 and procalcitonin identified an extra $10 \%$, at the cost of a 5\% false-positive rate. In conclusion, when febrile patients are screened on hospital admission to identify those with a high mortality risk and who may benefit from early preventive measures, sound clinical judgement based on age, underlying disease and recent history outweigh the predictive value of endotoxin, cytokine and procalcitonin levels. Only in patients who present in shock, measurement of endotoxin will help detect most nonsurvivors at the cost of few false-positives. 


\section{Introduction}

Despite a vast body of evidence implicating cytokines as mediators of sepsis, results of clinical trials with cytokine-based strategies are disappointing ${ }^{1}$. Though this has led to skepticism that immunotherapy would have a role in the management of sepsis, it has been suggested that cytokine-based strategies may be beneficial in specific subsets with a high mortality risk rather than in all patients with sepsis ${ }^{1}$. If this is indeed the case, a crucial question is whether such subgroups can be identified prospectively.

The reaction to infection can clinically be manifested by the systemic inflammatory response syndrome progressing to septic shock and multiple organ dysfunction syndrome ${ }^{1}$. This chain of events is triggered by bacterial components such as endotoxin, peptidoglycan, lipoteichoic acid, lipoprotein and exotoxins, and executed through many mediators ${ }^{2-4}$. The predictive value of circulating endotoxin and mediators including various pro- and anti-inflammatory cytokines for the clinical outcome has been studied in highly diverse groups of critically ill patients and yielded variable results. Interpretation of many studies on the role of such parameters in assessment of patients outcome in intensive care units may have been hampered by the nature of the underlying illnesses modulating the response to a superimposed, acute infection ${ }^{2,5-9}$. Recently, another marker, procalcitonin, the propeptide of calcitonin, was introduced and shown to be strongly associated with severity of sepsis ${ }^{8}$.

Although high circulating levels of inflammatory mediators like endotoxin, cytokines and procalcitonin are associated with an adverse outcome $e^{2,5-9}$, the efficacy relative to clinical judgment of determining these factors on admission to identify patients with an infection who are at risk for a complicated course and may benefit from early preventive measures, is not known. To assess the predictive value of plasma endotoxin, cytokine and procalcitonin concentrations relative to clinical judgement in a group of patients with an acute communityacquired infection of whom only a few suffered from an active underlying disease, we measured these concentrations on admission in a group of febrile patients with a community-acquired infection, and followed their clinical course.

\section{Methods}

The study was performed at the Leiden University Medical Center, an 800-bed secondary and tertiary referral hospital. Patients 18 years and older, consecutively referred to the Medicine Emergency Department because of a febrile illness (rectal temperature $38.2^{\circ} \mathrm{C}$ ) were enrolled. Following institutional approval and patients oral consent, clinical and microbiological data were obtained and registered ${ }^{10}$. Circulatory shock was defined as hypotension (systolic blood pressure $<90 \mathrm{mmHg}$; mean arterial tension $<65 \mathrm{mmHg}$ ) for more than $1 \mathrm{hr}$ with signs and symptoms of end-organ failure, despite fluid resuscitation; multiple organ dysfunction syndrome (MODS) 
was considered when a patient had 3 organ system failure during at least $24-\mathrm{hr}$ period ${ }^{1,11,12}$. Two blood cultures were collected that were incubated under aerobic and anaerobic conditions. In 309 of the 464 patients attending physicians ordered cultures from sites deemed to be responsible for the febrile illness. During clinical follow-up, antibiotic treatment, culture and serology data were recorded, as were the diagnoses of the attending physicians and infectious diseases consultant. Also, the duration of hospital stay and clinical course with respect to development of circulatory shock, MODS, and outcome (i.e. discharge or death) were recorded. Severity of underlying disease was documented according to the classification of McCabe and Jackson ${ }^{13}$.

Four hundred sixty four patients (272 men and 192 women) were entered in the prospective study $^{10}$. The median age was $61 \mathrm{yr}$ (range 18-97). Patients were admitted at a median of 1 day (IQR 0-3) after the onset of fever. Infection as cause of fever was definite on clinical and microbiological evidence (clinically identified focus of infection and positive blood and/or local culture from a normally sterile body site) in 223 (48\%) patients. Infection was judged highly probable on clinical grounds (e.g. by identified focus of infection and serology data) in another $141(30 \%)$ and was uncertain in 35 patients. The sites of infection and sources of bacteremia and endotoxemia are given in table 1 . Ninety patients (19\%) had bacteremia, of which 4 had both Gram-negative and Gram-positive bacteria in the blood. Gram-positive bacteremia was mainly caused by pneumococci $(n=27)$ and various species of streptococci $(n=15)$; the most common source of infection in these patients was the lower respiratory tract. In Gram-negative bacteremia, Enterobacteriaceae ( $n=40$, including 17 E. coli and 13 Klebsiella) dominated over non-Enterobacteriaceae (e.g., 2 P. aeruginosa and 2 enterobacter spp); the most common focus of infection was the urinary tract. Seven cases had malaria (P. falciparum 5; P. vivax 2). Empiric antibiotic treatment (according to hospital protocol) was judged adequate, i.e., at least one antibiotic to which the causative organism was susceptible and anaerobic coverage in abdominal infection, in $95 \%$ of the patients including all cases with bacteremia.

Of the 464 patients, 33 (7.1\%) died after a median hospital stay of 11 days; all but 2 died within 28 days. Seven of 31 patients who were in circulatory shock on admission died, of whom 4 after having developed MODS. Another 24 patients had a normal blood pressure on admission but became hypotensive during the first $24 \mathrm{hr}$. In this group 5 died, including 3 patients who developed MODS after the episode of shock. Overall, 19 patients developed MODS, of whom 14 died. In 28 of the 33 patients who died, an infection as cause of fever was certain: pneumonia (10), urosepsis (5), peritonitis (6), cholangitis (1), primary bacteremia (4), and meningococcal sepsis and pneumococcal meningitis (1 each). The other nonsurvivors died of a cerebrovascular accident (3) or myocardial infarction (2).

\subsection{Endotoxin, cytokines (IL-6, TNF-alpha, IL-10) and procalcitonin assays}

Endotoxin was determined in platelet-rich plasma by a quantitative photometric assay with end-point measurement as described ${ }^{10,14}$; concentrations $5 \mathrm{pg} / \mathrm{ml}$ were considered to indicate endotoxemia ${ }^{9}$. 
IL-6 and IL-10 concentrations were determined with a standard ELISA technique and TNF-alpha by a competitive inhibition radio immunoassay (Medgenix diagnostics, Floury, Belgium) ${ }^{10,15}$; the detection limit for cytokines was $5 \mathrm{pg} / \mathrm{ml}$. Procalcitonin was measured by the immunoluminometric assay adapted from the immunoradiometric assay; the detection limit was $0.1 \mathrm{ng} / \mathrm{ml}$. Blood was available for assay of endotoxin in 452 (98\%), of TNF-alpha in 462 (99\%), of IL-6 in 379 (82\%), of IL-10 in 419 (91\%) patients, and of procalcitonin in 381 (82\%); loss of completeness was due to incomplete sampling. Assay results were not available during the hospital stay of the patients.

\subsection{Analysis of data}

Logistic regression analysis was used to assess an association between endotoxin, cytokines and procalcitonin levels with outcome of hospitalization. Data of endotoxin, cytokine and procalcitonin levels were used after log-transformation ${ }^{10}$. Underlying disease was entered as categorical variable, as described by McCabe and Jackson ${ }^{13}$. When indicated, endotoxemia and elevated levels of procalcitonin $(0.5 \mathrm{ng} / \mathrm{ml})$ were entered as categorical variable. Multiple logistic regression was used to identify variables that were independently related to fatal outcome. The model included patient and laboratory data that can be obtained within hours after admission. The following characteristics were evaluated: gender, age, underlying disease, duration of fever prior to hospitalization, chills, prior use of antibiotics, vital signs on admission, circulatory shock, and endotoxin and cytokines. The multivariate analysis was performed by entering the variables one by one into the model, starting with the clinical variables and next selecting the strongest predictors. Statistical significance was tested two-tailed, with the p set to 0.05 . To study screening potential, the mortality risk was estimated separately for each patient from the values for the variables listed above obtained on admission, as modelled previously ${ }^{16}$. The detection rate of nonsurvival was defined as the proportion of patients who died during follow-up and who had a screening result above the false-positive rate, i.e. the proportion who did not die and who had a positive screening result. The false-positive rate was set arbitrarily at $5 \%$ or $10 \%$ by choosing appropriate risk cut-off values.

\section{Results}

\subsection{Clinical risk factors of mortality}

Age and underlying disease were significantly associated with mortality (Table 2); these associations were largely independent of each other. Furthermore, circulatory shock on admission was strongly associated with mortality (RR 4.6, 95\% CI: 1.8-11.6). The duration of fever before admission showed a trend towards association with mortality $(\mathrm{p}=0.10)$. The occurrence of chills correlated with bacteremia $(\mathrm{p}=0.04)$ which itself showed a trend $(\mathrm{p}=0.06)$ towards association with mortality. Since microbiological confirmation of bacteremia is not available within hours of admission, chills rather than bacteremia was included in the multivariate analysis as a basic clinical characteristic available on hospital admission, together with age, underlying disease and duration of fever. 


\subsection{Endotoxemia as risk factor of mortality}

On admission, 98 of 452 patients $(21.7 \%)$ had a plasma endotoxin level $\geqslant 5 \mathrm{pg} / \mathrm{ml}$ (Table 1$)$. Of these patients 16 died (17.2\%), compared with 16 (4.6\%) of 346 patients without endotoxemia (RR 4.0, 95\% CI: 1.9 to 8.4; Table 2). In 44 patients with Gram-negative bacteremia, only those with concomitant endotoxemia died, i.e. 5 (23\%) out of 22 endotoxemic patients in contrast to none of 22 without endotoxemia ( $\mathrm{p}=0.02)$. Of the 4 patients with polymicrobial bacteremia including Gram-negatives, only the 2 patients with endotoxemia died. Overall, of the 119 patients with a culture-proven Gram-negative infection, 12 died of whom 10 were endotoxemic.

\subsection{Cytokines as risk factors of mortality}

Plasma IL-6 and IL-10 levels were significantly associated with mortality, whereas TNF-alpha only showed a trend towards such an association $(\mathrm{p}=0.10)$. Dichotomized around the median, the mortality risk was 2.9 (95\% CI 1.2-7.1) and 2.5-fold (95\% CI 1.1-5.9) higher in those patients with a plasma concentration of IL-6 or IL-10 above the median, respectively, compared with those with values below the median. These mortality risks were not different between patients with a high or low plasma TNF-alpha.

\subsection{Procalcitonin as risk factor of mortality}

On admission, 207 of 381 patients (54\%) had an elevated level of procalcitonin, i.e. $\geqslant 0.5 \mathrm{ng} / \mathrm{ml}$. Of these patients 22 died (10.6\%), compared with 4 (2.3\%) of 174 patients, respectively, without an increased procalcitonin (RR 5.0, 95\% CI: 1.7 to 15 ). In $82 \%$ of patients with bacteremia the procalcitonin was $0.5 \mathrm{ng} / \mathrm{ml}$, as were $49 \%$ of the patients without bacteremia. However, in bacteremic patients a positive test for procalcitonin was not associated with mortality $(p=0.15)$. In the subgroup with a culture-proven gram-negative infection, a positive test of procalcitonin was associated with mortality (RR 6.8, 95\% CI 0.8-56), but -though more sensitive- proved less specific than endotoxin.

\subsection{Screening performance of clinical and laboratory variables.}

Rather than to try to identify by endotoxin and cytokine measurements those patients in the whole group who were on admission in such a poor condition that they are easily identified on clinical grounds (e.g. those in shock), the value of screening for endotoxemia, procalcitonin and cytokinemia was assessed in patients who on admission were in shock and compared with those who were not (Table 3). In the prediction model, clinical data concerning age, underlying disease and recent history with respect to the febrile episode are entered first, reflecting a 'real life' encounter between patient and physician in the emergence room. 


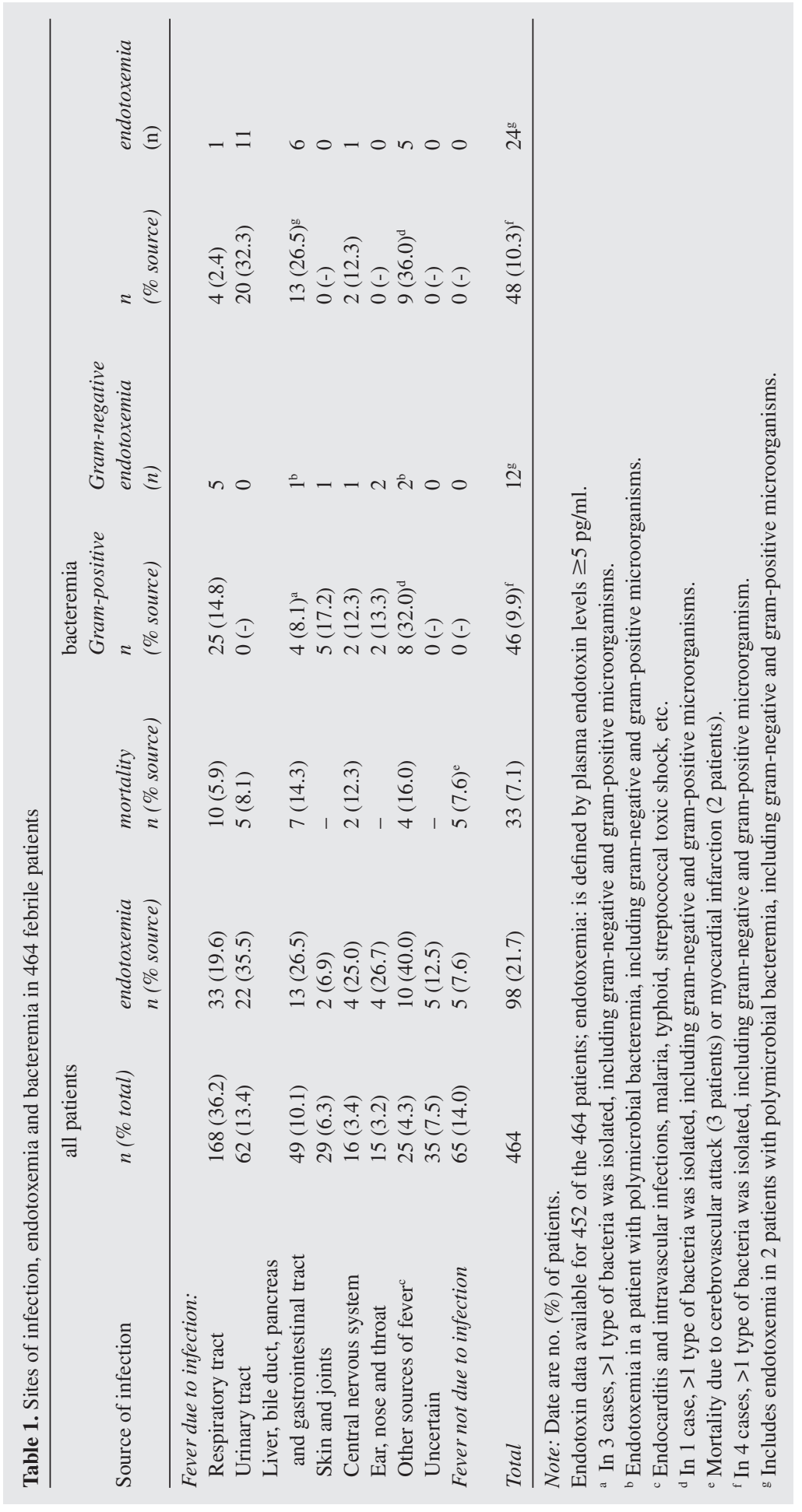


Table 2. Results of univariate analyses of clinical and laboratory data of 464 febrile patients.

\begin{tabular}{ll}
\hline Characteristic & $\begin{array}{l}\text { Relative Mortality risk } \\
(95 \% \mathrm{CI})\end{array}$ \\
\hline Clinical data & $1.05(1.03-1.1)$ \\
Age (yr) & $7.2(2.9-17.8)$ \\
Dichotomized at $\geq 65$ years & $0.8(0.4-1.7)$ \\
Male sex & $3.0(1.5-6.1)$ \\
Ultimately fatal or rapidly fatal underlying disease & $1.04(1.0-1.1)$ \\
Duration of fever (d) & $1.3(0.7-2.9)$ \\
Chills & $4.6(1.8-11.6)$ \\
Circulatory shock present on admission & $4.0(1.9-8.4)$ \\
Laboratory data & $10.6(2.2-51)$ \\
Endotoxemia & $1.6(0.8-3.4)$ \\
Endotoxemia in 119 culture-proven, & $2.9(1.2-7.1)$ \\
gram-negative infections & $2.6(1.1-5.9)$ \\
TNF-alpha & $5.1(1.7-15)$ \\
IL-6 & $1.9(0.9-3.9)$ \\
IL-10 & \\
Hyperprocalcitonemia &
\end{tabular}

Note: Underlying disease was classified according to McCabe and Jackson ${ }^{13}$. Endotoxemia was defined by an endotoxin level $\geq 5 \mathrm{pg} / \mathrm{ml}$, hyperprocalcitonemia was defined by a procalcitonin level $\geq 0.5 \mathrm{ng} / \mathrm{ml}$. Cytokines were dichotomized around median.

\subsection{Patients in shock on admission}

Of the 31 patients who were in shock on admission, 7 (23\%) died. The clinical data did not identify more than $15 \%$ of the nonsurvivors at the false-positive rates of 5 and $10 \%$. Unlike TNF-alpha, IL-6 and IL-10, the endotoxin level alone identified 6 (i.e., over $81 \%$ ) of the 7 nonsurvivors, beit at the cost of a $10 \%$ false-positive rate, and 5 (i.e., $71 \%$ ) of the nonsurvivors at a 5\% false-positive rate (Table 4). With the exception of measurement of TNF-alpha that slightly raised the detection of a fatal outcome, other cytokines or procalcitonin values did not improve the detection rate of the model any further.

\subsection{Patients not in shock on admission}

Of 433 febrile patients without shock on admission, 26 (6\%) did not survive. Clinical data alone already predicted $30-50 \%$ of total mortality, beit at the cost of a 5 or $10 \%$ false-positive rate (Table 4). For instance, at a $10 \%$ false-positive rate in patients not in shock on admission $(n=433)$, the table 4 demonstrates that a multivariate model including age, McCabe and fever will identify correctly 12 of 26 (46\%) patients with fatal outcome on top of 43 false-positives (i.e., $10 \%$ of 433 patients). Thus, $55(12+43)$ patients are screen-positive, but only 12 (i.e., $22 \%$, representing $46 \%$ of all fatalities) will die. Combining the clinical data with measurements of IL-6 and procalcitonin improved detection to about $41 \%$ at a $5 \%$ false positive rate, but did not improve detection at a $10 \%$ false-positive rate. Addition of TNF-alpha and IL-10 values did not improve the results of the multivariate model, whereas endotoxin measurements contributed 


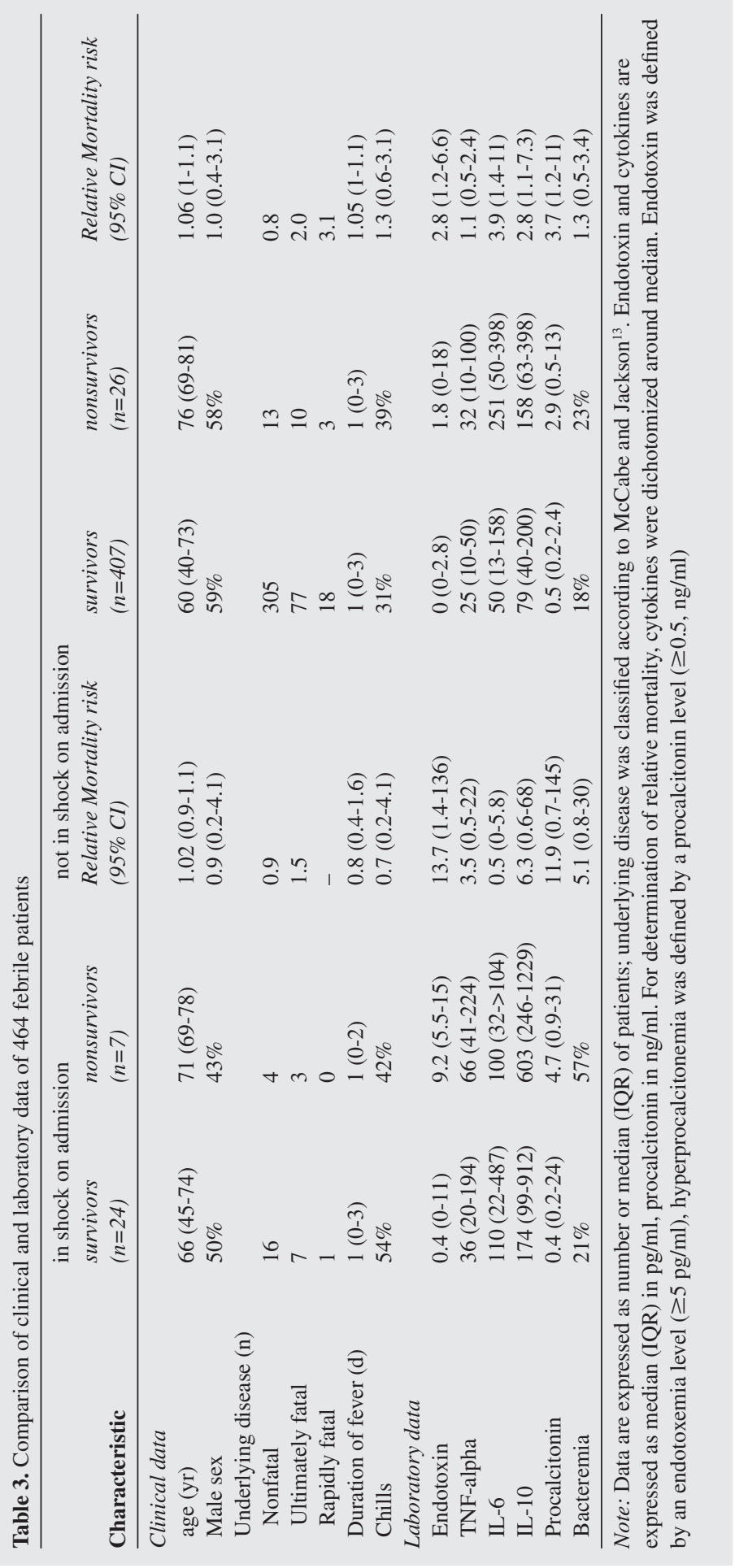


Table 4. Screening detection rates $(\%)$ for nonsurvival in febrile patients

\begin{tabular}{|c|c|c|}
\hline False-positive rate & $\begin{array}{l}\text { Detected with } \\
\text { in shock } \\
\text { on admission } \\
(\mathrm{n}=31)\end{array}$ & $\begin{array}{l}\text { outcome }(\%) \\
\text { not in shock } \\
\text { on admission } \\
(\mathrm{n}=433)\end{array}$ \\
\hline \multicolumn{3}{|l|}{$10 \%$ false-positive rate } \\
\hline Age & $0 / 7(-)$ & $7 / 26(27 \%)$ \\
\hline Age, McCabe & $0 / 7(-)$ & $12 / 26(46 \%)$ \\
\hline Age, McCabe, fever & $1 / 7(14 \%)$ & $12 / 26(46 \%)$ \\
\hline Age, McCabe, fever, chills & $1 / 7(14 \%)$ & $13 / 26(50 \%)$ \\
\hline Age, McCabe, fever, chills, endotoxin & $6 / 7(81 \%)$ & $13 / 26(50 \%)$ \\
\hline Age, McCabe, fever, chills, endotoxin, procalcitonin & $6 / 7(81 \%)$ & $14 / 26(54 \%)$ \\
\hline Age, McCabe, fever, chills, endotoxin, procalcitonin, cytokines & $6 / 7(81 \%)$ & $14 / 26(54 \%)$ \\
\hline \multicolumn{3}{|l|}{$5 \%$ false-positive rate } \\
\hline Age & $0 / 7(-)$ & $4 / 26(15 \%)$ \\
\hline Age, McCabe & $0 / 7(-)$ & $5 / 26(19 \%)$ \\
\hline Age, McCabe, fever & $0 / 7(-)$ & $6 / 26(23 \%)$ \\
\hline Age, McCabe, fever, chills & $0 / 7(-)$ & $7 / 26(27 \%)$ \\
\hline Age, McCabe, fever, chills, endotoxin & $5 / 7(71 \%)$ & $7 / 26(27 \%)$ \\
\hline Age, McCabe, fever, chills, endotoxin, procalcitonin & $5 / 7(71 \%)$ & $9 / 26(35 \%)$ \\
\hline Age, McCabe, fever, chills, endotoxin, procalcitonin, cytokines & $6 / 7(81 \%)^{\mathrm{a}}$ & $11 / 26(41 \%)^{b}$ \\
\hline 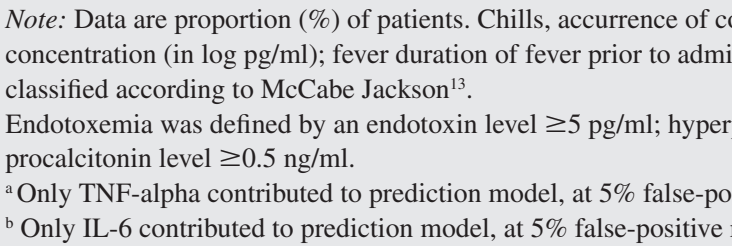 & $\begin{array}{l}\text { nills before adi } \\
\text { (in days); Mc } \\
\text { e rate }\end{array}$ & $\begin{array}{l}\mathrm{n} \text {; cytokine, } \mathrm{pl} \\
\text { underlying dis } \\
\text { ned by a }\end{array}$ \\
\hline
\end{tabular}

only modestly to the model in these patients (Table 4). Of note, these results were not affected by the loss of completeness of procalcitonin and IL-6 measurements (i.e., data available in $82 \%$ of the patients), and tested patients were not different from the patients who did not have the procalcitonin and IL-6 values determined.

\section{Discussion}

The association between mortality in patients with a community-acquired infection and plasma endotoxin, cytokine and procalcitonin levels is important in terms of the reduction in mortality that would follow a successful identification of those patients who might benefit from early intervention strategies. The present findings indicate that measuring on hospital admission plasma endotoxin, cytokine and procalcitonin levels in febrile patients can help only moderately to identify those patients. In this respect, the efficacy of a model that includes basic clinical data that can readily be obtained on admission, and endotoxin, IL-6 and procalcitonin measurements, appears to outweigh that of other combinations that include TNF-alpha and IL-10. At best, however, such a model will allow at the cost of a $10 \%$ false-positive rate only 
to identify about half of all patients who will have a fatal outcome. Thus, because the mortality rate in febrile patients with a community-acquired infection is quite low, i.e. less than $10 \%$, determining endotoxin, cytokine and procalcitonin levels performs too poorly to discriminate between those patients who might benefit from early preventive measures and who will not. Moreover, clinicians should realise that they will miss about half of the target group because it is screen-negative. Therefore they cannot take false reassurance about the clinical course in screen-negative febrile patients. An exception to this disappointing situation is the small group of patients who are in shock on admission and have a substantially higher mortality risk. In these patients, risk assessment using basic clinical data appears to be grossly inferior to that based on plasma endotoxin levels.

Rather than in the whole group identify patients who already are in an extreme phase of their illness on admission, the value of screening for endotoxemia, cytokinemia and hyper procalcitonemia was investigated in patients who on hospital presentation were clinically stable separately from those who presented in shock. In patients who were already in shock, nonsurvival appeared mainly associated with the severity of the acute host response to infection and not with age, activity of underlying disease or other clinical data. In this particular situation, endotoxemia proved a strong predictor of nonsurvival that greatly outmatched the predictive value of the cytokines, and in fact, most patients in shock who died had endotoxemia on admission. By contrast, in patients who on admission were clinically stable and normotensive, the main factors associated with a fatal outcome were high age and certain characteristics of underlying disease, and largely independent from these parameters, levels of IL-6 and procalcitonin as well. We found little influence of microbiological findings on the prognosis after adjustment for other significant risk factors for nonsurvival, which is in accordance with published data ${ }^{12,18}$.

As the efficacy of an intervention is generally judged by its effect on the mortality rate, one should be able to identify these high-risk patients preferably on admission, because at that moment they should be considered for specific measures or inclusion in trials for treatment of severe sepsis. Readily available information such as age and activity of underlying diseases as well as the vital signs help the clinician to estimate the severity of illness. As demonstrated in the present study, however, such clinical data in combination with measurement of endotoxin and selected cytokine and procalcitonin levels will help the clinician to identify only about halve of the patients with a high mortality risk and this at the cost of an even larger number of falsepositives. Thus, even when a rapid and reliable endotoxin and cytokine test would be available, out of every 100 patients only 4 of the 8 expected nonsurvivors can be identified at the cost of 10 false-positives, i.e. patients with a positive screening result who will not die.

In this study the outcome of infections caused by gram-negative microorganisms was determined to a large extent by the presence of endotoxemia. In patients with gram-negative bacteremia those 
who died had both endotoxemia and bacteremia. This finding underscores the predictive value of data on endotoxemia in patients with gram-negative infections. Until now a substantially increased risk of mortality in endotoxemic patients appeared from meta-analyses ${ }^{2,19-24}$. Though in this study we focussed on the predictive value of endotoxin and cytokine levels rather than underlying pathophysiological mechanisms ${ }^{10}$, the findings illustrate that distinction must be made with respect to the inflammatory response elicited by circulating free endotoxin and that by intact gram-negative bacteria, even though in the latter a high amount of bacterial cell-bound endotoxin is present. Our data add to previous studies showing that septic shock occurs more frequently among patients with both endotoxemia and gram-negative bacteremia compared with those with only bacteremia ${ }^{2}$, and confirm that bacteremia in itself is a weak predictor of clinical outcome. Strong associations between endotoxemia and outcome were observed in patients with meningococcemia, plague and leptospirosis, but not in a number of studies on hospitalized patients with sepsis syndrome due to other causes ${ }^{6,9,22-29}$. In many studies intensive care patients were included and in most of these the presentation of the acute illness was complicated by an active underlying condition. As our study sample included only few patients with active underlying disease, the sample size may have limited the power to detect the impact of predictors of outcome in patients in whom the severity of illness was comparable to that in the intensive care patients.

In our study only patients admitted because of a community-acquired febrile illness were eligible for inclusion. Although the population was heterogenous in terms of age, site of infection, etc, in general patients were acutely ill and few had an underlying disease. The mixture of patients with community-acquired infection in our study represents that seen in many university and large community hospitals ${ }^{17,18}$. Since we did not evaluate the predictive potential of the parameters in already hospitalized critically-ill patients after referral to an intensive care unit, our findings do not exclude that such measurements of endotoxin, cytokines and procalcitonin may be relevant in such a selected patient group.

\section{Acknowledgements}

The study was supported by the PraeventieFonds (grant M28-2293) and an educational grant from Glaxo Welcome bv (Zeist, Netherlands). We thank Vicky Schijf, Nils P.J. Vogtländer, Ans Matze and all nursing staff of the Medical Emergency Department for excellent technical support, and Dr. Jan Thompson for critical reading of the manuscript. 


\section{References}

1 Bone R.C. Immunologic dissonance: a continuing evolution in our understanding of the systemic inflammatory response syndrome (SIRS) and the multiple organ dysfunction syndrome (MODS). Ann Intern Med 1996; 125:680-7.

2 Hurley J.C. Reappraisal with meta-analysis of bacteremia, endotoxemia and mortality in Gram-negative sepsis. J Clin Microbiol 1995; 33:1278-82.

3 Timmerman C.P., Mattson E., Martinez-Martinez L., de Graaf L., van Strijp J.A., Verbrugh H.A., Verhoef J., Fleer A. Induction of release of tumour necrosis factor from human monocytes by staphylococci and staphylococcal peptidoglycan. Infect Immun 1993; 61:4167-72.

4 van Langevelde P., van Dissel J.T., Ravensbergen E., Appelmelk B.J., Schrijver I.A., Groeneveld P.H.P. Antibiotic-induced release of lipoteichoic acid and peptidoglycan from Staphylococcus aureus: quantitative measurements and biological activity. Antimicrob Agents Chemother 1998; 42:3073-8.

5 Levin J., Poore T.E., Young N.S., Margolis S., Zauber N.P., Townes A.S., Bell W.R. Gram-negative sepsis: detection of endotoxemia with the limulus test with studies of associated changes in blood coagulation, serum lipids and complement. Ann Inter Med 1972; 76:1-7.

6 van Deventer S.J.H., Buller H.R., ten Cate J.W., Sturk A., Pauw W. Endotoxemia: an early predictor of septicaemia in febrile patients. Lancet 1988; i:605-8.

7 de Werra I., Jaccard C., Corradin B., Chioléro R., Yersin B., Gallati H., Assicot M., Bohuon C., Baumgartner J.D., Glauser M.P., Heumann D. Cytokines, nitrite/nitrate, soluble tumor necrosis factor receptors, and procalcitonin concentrations: comparisons in patients with septic shock, cardiogenic shock and bacterial pneumonia. Crit Care Med 1997; 25:607-13.

8 Assicot M., Gendrel D., Carsin H., Raymond J., Guilbaud J., Bohuon C. High serum procalcitonin concentrations in patients with sepsis and infection. Lancet 1993; 341:515-8.

9 Bossink A.W.J., Groeneveld A.B.J., Thijs L.G. Prediction of microbial infection and mortality in medical patients with fever: plasma procalcitonin, neutrophilic elastase-a1-antitrypsin, and lactoferrin compared with clinical variables. Clin Infect Dis 1999; 29:398-407.

10 Van Dissel J.T., Van Langevelde P., Westendorp R.G.J., Kwappenberg K., Frölich M. An antiinflammatory cytokine profile is associated with mortality in febrile patients admitted to the hospital. Lancet 1998; 351:950-3.

11 Hess D.G., Tracey K.J., Fong Y., Manogue K.R., Palladino M.A.Jr., Cerami A., Shires G.T., Lowry S.F. Cytokine appearance in human endotoxemia and primate bacteremia. Surg Gynecol Obstet 1988; 166:147-53.

12 Goldie A.S., Fearon K.C., Ross J.A., Barclay G.R., Jackson R.E., Grant I.S., Ramsay G., Blyth A.S., Howie J.C. Natural cytokine antagonists and endogenous anti-endotoxin core antibodies in sepsis syndrome. JAMA 1995; 274:172-7.

13 McCabe W.R., Jackson G.G. Gram-negative bacteremia, I: etiology and ecology. Arch Intern Med 1962; 110:847-53.

14 Sturk A., Janssen M.E., Muylaert F.R., Joop K., Thomas L.L., ten Cate J.W. Endotoxin testing in blood. Prog Clin Biol Res 1987; 231:371-85.

15 Westendorp R.G.J., Langermans J.A.M., de Bel C.E., Meinders A.E., Vandenbroucke J.P., van Furth R., van Dissel J.T. Release of tumour necrosis factor: an innate host characteristic that may contribute to the outcome of meningococcal disease. J Infect Dis 1995; 171:1057-60.

16 Wald N.J., Cuckle H.S., Densem J.W., Nanchahal K., Royston P., Chard T., Haddow J.E., Knight G.J., Palomaki G.E., Canick J.A. Maternal serum screening for Down's syndrome in early pregnancy. Br Med J 1988; 297:883-7.

17 Leibovici L., Greenshtain S., Cohen O., Mor F., Wysenbeek A.J. Bacteremia in febrile patients. A clinical model for diagnosis. Arch Intern Med 1991; 151:1801-6.

18 Bates D.W., Pruess K.E., Lee T.H. How bad are bacteremia and sepsis? Outcomes in a cohort with suspected bacteremia. Arch Inter Med 1995; 155:593-8. 
19 Hamilton G., Hofbauer S., Hamilton B. Endotoxin, TNF-alpha, interleukin-6 and parameters of the cellular immune system in patients with abdominal sepsis. Scan J Infect Dis 1992; 24:361-8.

20 Heath D.I., Cruickshank A., Gudgeon M., Jehanli A., Shenkin A., Imrie C.W. Role of interleukin-6 in mediating the acute phase protein response and potential as an early means of severity assessment in acute pancreatitis. Gut 1993; 34:41-5.

21 Fisher C.J., Agosti J.M., Opal S.M., Lowry S.F., Balk R.A., Sadoff J.C., Abraham E., Schein R.M., Benjamin E. Treatment of septic shock with the tumour necrosis factor receptor:Fc fusion protein. N Engl J Med 1996; 334:1697-702.

22 Bayston K.F., Cohen J. Bacterial endotoxin and current concepts in the diagnosis and treatment of endotoxemia. J Med Microbiol 1990; 31:73-83.

23 Goto T., Makinose S., Ohi Y. Plasma endotoxin concentrations in patients with urinary tract infections. Int J Urol 1995; 2:238-242.

24 Weinstein M.P., Towns M.L., Quartey S.M., Mirrett S., Reimer L.G., Parmigiani G., Reller L.B. The clinical significance of positive blood cultures in the 1990s: a prospective comprehensive evaluation of the microbiology, epidemiology, and outcome of bacteremia and fungemia in adults. Clin Infect Dis 1997; 24:584-602.

25 Danner R.L., Elin R.J., Hosseini M., Wesley R.A., Reilly J.M., Parillo J.E. Endotoxemia in human septic shock. Chest 1991; 99:169-75.

26 Dofferhoff A.S.M., Bom V.J.J., de Vries-Hospers H.G., van Ingen J., van der Meer J., Hazenberg B.P., Mulder P.O., Weits J. Patterns of cytokines, plasma endotoxin, plasminogen activator, and acute phase proteins during treatment of severe sepsis in humans. Crit Care Med 1992; 20:185-92.

27 Shenep J.L., Flynn P.M., Barrett F.F., Stidham G.L., Westenkirchner D.F. Serial quantitation of endotoxemia and bacteremia during therapy for gram-negative bacterial sepsis. J Infect Dis 1988; 157:565-8.

28 Wortel C.H., van der Mohlen H.A.M., van Deventer S.J.H., Sprung C.L., Jastremski M., Lubbers M.J., Smith C.R., Allen I.E., ten Cate J.W. Effectiveness of a human monoclonal anti-endotoxin antibody (HA-1A) in Gram-negative sepsis: relationship to endotoxin and cytokine levels. J Infect Dis 1992; 166:1374-8.

29 Yoshida M., Obayashi T., Tamura H., Tanaka S., Kawai T., Sakamoto S., Miura Y. Diagnostic and prognostic significance of plasma endotoxin determination in febrile patients with hematologic malignancies. Eur J Cancer 1994; 30A:145-7. 


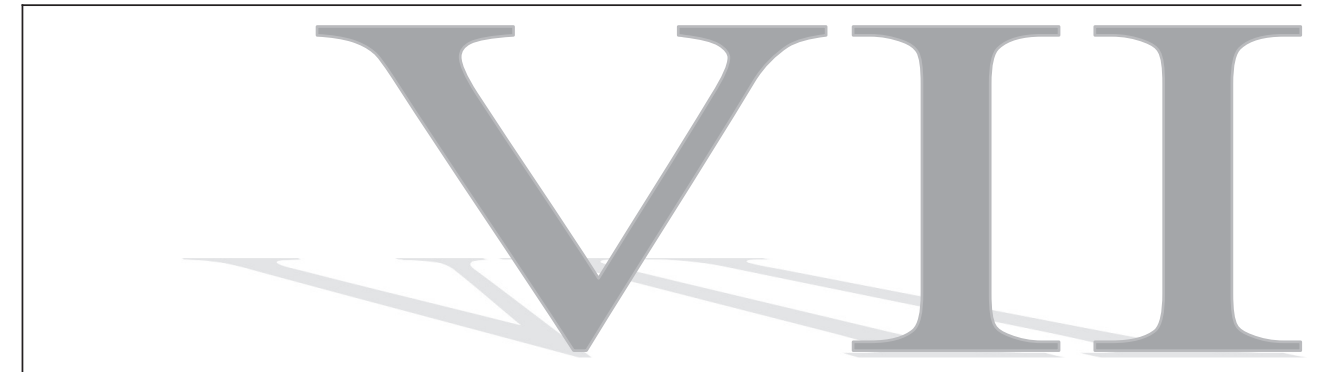

\section{Microparticles from patients with multiple organ dysfunction syndrome and sepsis support cougulation through multiple mechanisms}

K. Joop, R. Berckmans, R. Nieuwland, J. Berkhout, F. Romijn, C.E. Hack, A. Sturk

\section{Contents chapter VII}

1. Introduction

2. Patients, materials and methods

2.1 Patients and healthy individuals

2.2 Collection of blood samples

2.3 Reagents and assays

2.4 Isolation of microparticles

2.5 Flow cytometric analysis

2.6 Thrombin generation assay

2.7 Statistical methods

3. Results

3.1 Inflammatory response and relation to circulation MP ….................................................... 115

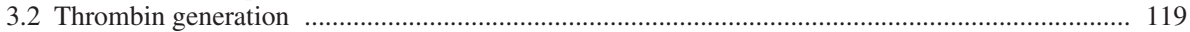

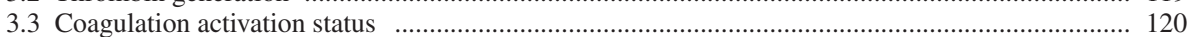

3.4 Inflammatory response and relation to circulation MP ..................................................... 121

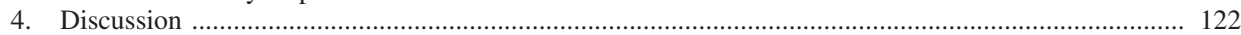

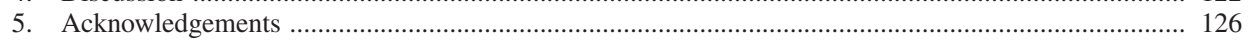

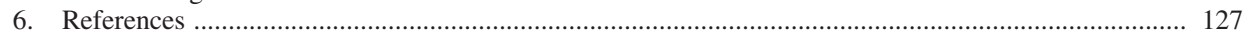




\section{Abstract}

Aim. We investigated the occurrence and thrombin generating mechanisms of circulating microparticles (MP) in patients with multiple organ dysfunction syndrome (MODS) and sepsis.

Methods. MP, isolated from blood of patients $(n=9)$ and healthy controls $(n=14)$, were stained with cell-specific monoclonal antibodies (MoAbs) or anti-tissue factor (anti-TF) MoAb and annexin $\mathrm{V}$, and analyzed by flow-cytometry. To assess their thrombin-generating capacity, MP were reconstituted in normal plasma. The coagulation activation status in vivo was quantified by plasma prothrombin fragment F1+2 and thrombin-antithrombin (TAT) measurements.

Results. Annexin V positive MP in the patients originated predominantly from platelets (PMP), and to a lesser extent from erythrocytes, endothelial cells (EMP) and granulocytes (GMP). Compared to healthy controls, the numbers of annexin V-positive PMP and TF exposing MP were decreased $(\mathrm{P}=<0.001$ for both), EMP were decreased (E-selectin, $\mathrm{P}=0.003$ ) or found equal (CD144, $\mathrm{p}=0.063)$, erythrocyte derived MP were equal ( $\mathrm{P}=0.726)$, and GMP were increased $(\mathrm{P}=0.008)$. GMP numbers correlated with plasma concentrations of elastase $(\mathrm{r}=0.70, \mathrm{P}=0.036)$, but not with $\mathrm{C}$-reactive-protein or interleukin-6 concentrations. Patient samples also contained reduced numbers of annexin $\mathrm{V}$ negative PMP, and increased numbers of erythrocyte derived MP and GMP ( $\mathrm{P}=0.005, \mathrm{P}=0.021$ and $\mathrm{P}<0.001$, respectively). Patient MP triggered thrombin formation, which was reduced compared to the healthy controls $(\mathrm{P}=0.008)$ and strongly inhibited by an anti-factor XII MoAb (two patients), by anti-factor XI MoAb (eight patients) or by anti-TF $\mathrm{MoAb}$ (four patients). Concentrations of $\mathrm{F} 1+2$ and TAT were elevated $(\mathrm{P}=0.005$ and $\mathrm{P}=0.001$, respectively) and correlated inversely with the number of circulating $\mathrm{MP}$ (and $\mathrm{r}=-0.51, \mathrm{P}=0.013$, and $\mathrm{r}=-0.65, \mathrm{P}=0.001$, respectively) and their thrombin generation capacity $(\mathrm{F} 1+2: \mathrm{r}=-0.62$, $\mathrm{P}=0.013)$.

Conclusions. In patients with MODS and sepsis relatively low numbers of MP are present that differ from controls in their cellular origin, numbers and coagulation activation mechanisms. 


\section{Introduction}

Cells undergoing activation or apoptosis release small parts of their outer membrane, the so-called microparticles (MP). Extensive studies have been reported on MP generated from blood platelets (PMP) in vitro ${ }^{1,2}$. These MP expose negatively charged phospholipids, thereby providing binding sites for activated coagulation factors V (factor Va), VIIIa, IXa and XIa ${ }^{1-4}$. As a consequence, these PMP are procoagulant by providing 'phospholipid cofactor'. In vitro, other cell-types such as monocytes, endothelial cells and erythrocytes also release MP upon appropriate stimulation ${ }^{5-7}$.

In vivo, increased numbers of PMP are found in the circulation of patients with an increased risk for thromboembolic events, i.e. patients with diabetes ${ }^{8,9}$, patients undergoing cardiac surgery ${ }^{10}$, or patients suffering from acute coronary ischaemia ${ }^{11}$, heparin-induced thrombocytopenia ${ }^{12}$, myocardial infarction ${ }^{13}$, uremia ${ }^{14}$, idiopathic thrombocytopenic purpura ${ }^{15}$ and disseminated intravascular coagulation (DIC) ${ }^{16,17}$. Previously, we reported elevated numbers of PMP and erythrocyte derived MP in the pericardial fluid of patients undergoing cardiopulmonary bypass surgery, and demonstrated that the isolated MP facilitated thrombin generation via the extrinsic pathway, i.e. tissue factor (TF)/factor VII dependent ${ }^{18}$. Subsequently, we reported elevated numbers of PMP and MP derived from monocytes and granulocytes in the circulation of patients with meningococcal septic shock and provided evidence that exposure of TF on MP might be involved in the pathogenesis of DIC ${ }^{17}$. Finally, we were also able to measure low numbers of MP especially from platelets and erythrocytes- in the circulation of healthy individuals. Those MP triggered low levels of thrombin generation in vitro via a TF/factor VII-independent mechanism. This thrombin generation was partially inhibited by blockade of factors XII or XI ${ }^{19}$. Recently, Combes and coworkers reported elevated numbers of endothelial cell-derived MP (EMP) in the circulation of patients with systemic lupus erythematosus (SLE) when compared to healthy individuals ${ }^{20}$.

Meningococcal septic shock is a very severe, rapidly progressive disease, which may not be representative for other more protracted septic conditions. In the present study we investigated the cellular source and thrombin generating capacity of MP in patients with multiple organ dysfunction syndrome (MODS) and sepsis, and a possible relation of those MP to the activation status of the coagulation system in vivo. We also investigated a possible relation between the number of MP in the circulation and the extent of the inflammatory response, as indicated by the plasma concentrations of interleukin-6 (IL-6), elastase and the acute phase reactant C-reactive protein (CRP). 


\section{Patients, materials and methods}

\subsection{Patients and healthy individuals}

Patients with MODS and sepsis were investigated. The patients entered the study between July 1998 and March 1999 and were hospitalized in the Intensive Care Unit of the Leiden University Medical Center (LUMC). Of the nine patients (2 female and 7 male; age: 60 years (median), range 26-71), six had bacteremia whereas the others had a local bacterial infection. Patients developed MODS and sepsis after surgery (six patients), pancreatitis (one), multitrauma (one) or Escherichia (E) coli meningitis (one). Patients were considered to have sepsis if they fulfilled the criteria for a systemic inflammatory response syndrome (SIRS) and had evidence for a systemic and/or local bacterial infection ${ }^{21}$. The criteria to establish SIRS were more than one of the following: (I) a temperature $>38^{\circ} \mathrm{C}$ or $<36^{\circ} \mathrm{C}$; (II) tachycardia ( $>90$ beats/minute); (III) tachypnea (respiratory rate $>20$ breaths/ minute or $\mathrm{PaCO}_{2}<32 \mathrm{~mm} \mathrm{Hg}$ ); and (IV) a white blood cell count $>12 \times 10^{9} / \mathrm{L}$ or $<4 \times 10^{9} / \mathrm{L}$, or the presence of $>10 \%$ immature neutrophils ${ }^{21}$. The diagnosis SIRS was made by the attending physician and checked by one of the study clinicians. MODS was defined as a failure of 3 or more organ systems for at least 24 hours $^{21}$. Of the nine patients, five patients died within 28 days. Individual patient characteristics, including platelet- and white blood cell counts, are presented in table 1. Of the nine patients, 7 had elevated numbers of white blood cell counts $\left(>10 \mathrm{x} 10^{9} / \mathrm{L}\right)$, whereas 5 patients were thrombocytopenic $\left(<150 \times 10^{9} / \mathrm{L}\right)$. As controls, 14 adult healthy individuals were also investigated for the presence, cellular source and thrombin generating capacity of MP. The healthy individuals had not taken any medication for at least ten days prior to the blood collection. The study was approved by the medical ethical committee (234-94/5/DPE/EN) of the LUMC.

\subsection{Collection of blood samples}

Blood was collected into 3.2\% trisodium citrate (BD, San Jose, CA, USA). Blood cells were removed within 5 minutes after blood collection by centrifugation for 20 minutes at $1550 x \mathrm{~g}$ and room temperature. For flow cytometry, MP were isolated (see below) from fresh plasma

Table 1. Patient characteristics.

\begin{tabular}{llllllll}
\hline Patient & Age & $\begin{array}{l}{ }^{1} \text { Gender } \\
\text { count }\end{array}$ & ${ }^{2}$ Platelet & ${ }^{2}$ WBC count & Cause of sepsis & $\begin{array}{l}\text { Positive } \\
\text { culture }\end{array}$ & ${ }^{3}$ Mortality \\
\hline 1 & 67 & M & 54 & 14.3 & Post-operative & Blood & Survivor \\
2 & 35 & M & 193 & 15.8 & Post-operative & Blood & Survivor \\
3 & 55 & M & 102 & 6.0 & Post-operative & Blood & Non-survivor \\
4 & 43 & F & 223 & 25.3 & Post-operative & Blood & Non-survivor \\
5 & 71 & M & 113 & 29.6 & Pancreatitis & Blood & Survivor \\
6 & 61 & F & 63 & 9.3 & E. coli meningitis & ${ }^{4}$ CSF & Non-survivor \\
7 & 26 & M & 167 & 18.1 & Multi trauma & Blood & Non-survivor \\
8 & 60 & M & 166 & 15.4 & Post-operative & Sputum & Non-survivor \\
9 & 62 & M & 121 & 13.9 & Post-operative & Aneurysm & Survivor \\
\hline${ }^{1} \mathrm{M}=$ male, F=female; ${ }^{2}$ Whole blood platelet- and white blood cell counts $(x 109 / 1) ;{ }^{3}$ Within 28 days after onset of
\end{tabular}


samples. The concentrations of prothrombin fragment F1+2, thrombin-antithrombin complex (TAT), IL-6, elastase and CRP, and thrombin generation experiments were determined in aliquots of plasma that were first snap frozen in liquid nitrogen, and then stored at $-80^{\circ} \mathrm{C}$ until use.

\subsection{Reagents and assays}

Reptilase was obtained from Roche (Basel, Switzerland) and the chromogenic substrate S2238 from Chromogenix AB (Mölndal, Sweden). Murine normal serum was obtained from the Central Laboratory of the Netherlands Red Cross Blood Transfusion Service (CLB; Amsterdam, The Netherlands), anti-Glycophorin A-FITC (JC159, IgG I $_{1}$ and CD61-FITC (Y2/51, IgG $)$ from

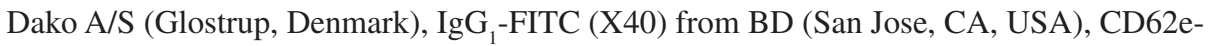
FITC (1.2B6, $\mathrm{IgG}_{1}$ ) from Serotec Ltd (Oxford, England), CD66b-FITC $\left(80 \mathrm{H} 3, \mathrm{IgG}_{1 \mathrm{k}}\right)$ from

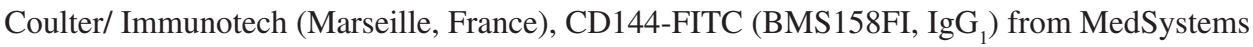
Diagnostics GmbH (Vienna, Austria), annexin V-APC from Caltag Laboratories (Burlingame, CA, USA) and annexin V-PE from PharMingen (San Jose, CA, USA). OT-2 (0.71 mg/ml), a $\mathrm{MoAb}$ which inhibits the activity of factor XII(a), was prepared as described earlier ${ }^{22}$. MoAb directed against factor XI (clone XI-1 $(0.92 \mathrm{mg} / \mathrm{ml})$ ) was also from the CLB. Anti-TF-FITC (4508CJ, $\left.\mathrm{IgG}_{1}\right)$ and polyclonal rabbit anti-human TF (1 mg/ml; clone 4502) were from American Diagnostics, Inc. (Greenwich, CT, USA). Plasma concentrations of F1+2 and TAT (Behring Diagnostics GmbH, Marburg, Germany), elastase (DPC, Nauheim, Germany) and IL-6 (CLB) were determined by ELISA as described by the manufacturers. CRP was measured on a Hitachi 911 analyzer (Roche, Basel, Switzerland) by immunoturbidimetric assay as described by the manufacturer.

\subsection{Isolation of microparticles}

After removal of cells, $250 \mu \mathrm{l}$ plasma were centrifuged for 30 minutes at $17570 \mathrm{x} \mathrm{g}$ and $20^{\circ} \mathrm{C}$. Subsequently, $225 \mu \mathrm{l}$ of (MP-free) plasma were removed. The remaining (MP-enriched) plasma, $25 \mu \mathrm{l}$, was diluted with $225 \mu \mathrm{l}$ of phosphate-buffered saline (PBS; $154 \mathrm{mmol} / \mathrm{l} \mathrm{NaCl}, 1.4 \mathrm{mmol} / \mathrm{l}$ phosphate, $\mathrm{pH} 7.4$ ), containing $10.9 \mathrm{mmol} / \mathrm{l}$ trisodium citrate to prevent coagulation activation. MP were resuspended and centrifuged for 30 minutes at $17570 \mathrm{x} \mathrm{g}$ at $20^{\circ} \mathrm{C}$. Again, $225 \mu \mathrm{l}$ of the supernatant were removed and MP were resuspended in the remaining $25 \mu \mathrm{l}$. For the thrombin generation experiments, $20 \mu \mathrm{l}$ of this suspension were used. For flow-cytometry, $25 \mu \mathrm{MP}$ suspension was diluted fourfold with PBS/citrate buffer, of which $5 \mu \mathrm{l}$ were used per incubation with MoAb and annexin V.

\subsection{Flow cytometric analysis}

MP analysis was performed as described previously ${ }^{17,18}$. Briefly, MP $(5 \mu \mathrm{l})$ were diluted in $35 \mu \mathrm{l}$ PBS containing $2.5 \mathrm{mmol} / \mathrm{l} \mathrm{CaCl}_{2}(\mathrm{pH} \mathrm{7.4)}$ ) and $5 \mu \mathrm{l}$ of 1 to 500 diluted (in PBS) normal mouse serum. After incubation for 15 minutes at room temperature, $5 \mu \mathrm{l}$ annexin V-PE and $5 \mu \mathrm{l}$ FITClabeled cell-specific MoAbs or isotype-matched control antibody were added. The mixtures were 
incubated in the dark for 15 minutes at room temperature. Subsequently, $200 \mu \mathrm{PBS} /$ calcium buffer were added and the suspensions centrifuged for 30 minutes at $17570 \mathrm{x}$ g and $20^{\circ} \mathrm{C}$. Finally, $200 \mu \mathrm{l}$ of (MP-free) suspension were removed. The MP were resuspended with 300 $\mu \mathrm{lBS} /$ calcium buffer before flow-cytometry. All samples were analyzed for 1 minute during which the flow cytometer analyzed approximately $150 \mu \mathrm{l}$ of the suspension. To estimate the number of MP/L plasma, the number of MP $(\mathrm{N})$ found in the upper right (marker positive and annexin $\mathrm{V}$ positive) and lower right (marker positive and annexin $\mathrm{V}$ negative) quadrants of the flow-cytometry analysis (FL1 versus FL2, corrected for isotype control and autofluorescence) was used in the formula: Number/l=N x [100/5] x [355/150] x [106/250]. The lower detection limit of the particle count was established in the samples with the $\mathrm{IgG}$ control as $5 \times 10^{6} \mathrm{MP} / \mathrm{l}$. The samples were analyzed in a FACScan flow cytometer with CellQuest software (BD, San Jose, CA, USA). Forward scatter (FSC) and sideward scatter (SSC) were set at logarithmic gain. To distinguish MP from events due to noise, MP were identified on FSC, SSC and binding of a $\mathrm{MoAb}$ directed against a cell-specific antigen. To identify annexin $\mathrm{V}$ positive events, a threshold was placed in a MP sample prepared without any additions to correct for autofluorescence. To identify MP that bound cell-specific MoAbs, MP were incubated with identical concentrations of isotype-matched control antibodies to set the threshold. FITC-fluorescence was measured in the FL-1 channel and PE-fluorescence in the FL-2 channel. The anti-CD144 antibody became only recently available to us, once we had started to perform our analysis on a FACSCalibur flow cytometer from Becton Dickinson (San Jose, CA, USA). This antibody was used in conjunction with annexin V-APC and anti-CD62e-PE. In all other aspects the CD144 analysis was performed as described for the other antibodies.

\subsection{Thrombin generation assay}

The thrombin generation test (TGT) as described by Béguin et al. ${ }^{23}$ was used to assess the thrombin generating capacity of the MP. In brief, isolated MP were reconstituted in defibrinated, MP-free normal plasma. MP were isolated from stored $\left(-80^{\circ} \mathrm{C}\right)$ plasma from patients $(n=9)$ and healthy controls $(n=6)$. Defibrinated plasma was prepared by incubating MP-free normal plasma (a pooled plasma from 20 healthy individuals, that had been centrifuged for 30 minutes at $17570 \mathrm{x} \mathrm{g}$ and $20^{\circ} \mathrm{C}$ ) with reptilase for 10 minutes at $37^{\circ} \mathrm{C}$ and, subsequently, for 10 minutes on melting ice. The fibrin clot was removed by centrifugation for 30 minutes at $17570 \mathrm{x} \mathrm{g}$ and $20^{\circ} \mathrm{C}$. Since MP adhere to fibrin, the plasma aliquots from which MP were isolated were not defibrinated ${ }^{24}$. MP $(20 \mu \mathrm{l})$ was added to $120 \mu \mathrm{l}$ of defibrinated plasma in all experiments. At $\mathrm{t}=0$, thrombin generation was triggered by the addition of $30 \mu \mathrm{CaCl}_{2}(16.7$ $\mathrm{mmol} / \mathrm{l}$ final concentration) to a prewarmed $\left(37^{\circ} \mathrm{C}\right)$ mixture of plasma, MP and buffer A (10 $\mu \mathrm{l} ; 50 \mathrm{mmol} / \mathrm{l}$ Tris- $\mathrm{HCl}, 100 \mathrm{mmol} / \mathrm{l} \mathrm{NaCl}, 0.05 \%$ bovine serum albumin, $\mathrm{pH} 7.35$ ). At fixed intervals after $\mathrm{t}=0,3 \mu \mathrm{l}$ aliquots were removed from this mixture and added to $147 \mu \mathrm{l}$ prewarmed $\left(37^{\circ} \mathrm{C}\right)$ chromogenic substrate S2238 in buffer B $(50 \mathrm{mmol} / \mathrm{l} \mathrm{Tris}-\mathrm{HCl}, 100 \mathrm{mmol} / \mathrm{l} \mathrm{NaCl}, 20$ $\mathrm{mmol} / \mathrm{l}$ EDTA and $0.05 \%$ bovine serum albumin, $\mathrm{pH} 7.90)$. After 3 minutes, the conversion of S2238 was stopped by the addition of $90 \mu \mathrm{l}$ citric acid $(1.0 \mathrm{~mol} / \mathrm{l})$ and the generated amount 
of p-nitroaniline was determined at $\lambda=405 \mathrm{~nm}$. In the inhibition experiments, the mixture of plasma plus buffer A, and separately the MP, were incubated with $20 \mu \mathrm{l}$ and $10 \mu \mathrm{l}$ of antibodies, respectively. In preliminary experiments the concentration yielding maximal inhibition was determined for each antibody. These were anti-TF $(1 \mathrm{mg} / \mathrm{ml}$ initial concentration), anti-FXI $(0.92 \mathrm{mg} / \mathrm{ml})$ and anti-FXII $(0.71 \mathrm{mg} / \mathrm{ml})$. After 30 minutes pre-incubation at room temperature, the MP were added and incubated for 10 minutes at $37^{\circ} \mathrm{C}$, whereupon the thrombin generation was started by addition of $\mathrm{CaCl}_{2}$. For quantitative analysis, the results were determined as the area under the curve and expressed as milligram $(\mathrm{mg}$ ) of the graph paper being weighed. Compared to unfrozen MP from healthy controls, after freeze/thawing these MP generate more thrombin as the area under the (thrombin generation) curves increases about two fold, but the proportion of inhibition by individual antibodies (such as anti-FXI, anti-FXII, anti-TF or antiFVII) is unaffected by freeze/thawing. In preliminary experiments, we observed that the increase in the area under the curve of the thrombin generation experiments upon freezing/thawing may be somewhat dependent upon the composition of the MP in the plasma sample. This indicates that the absolute thrombin generation capacities of stored microparticle preparations have to be interpreted with some caution. However, the freezing/thawing did not influence the percentage of inhibition by the various antibodies regardless of the composition of the microparticle populations, and thus the pathways observed to initiate the thrombin generation seem to be unaffected by the freezing/thawing process ${ }^{19}$.

\subsection{Statistical methods}

Data were analyzed with SPSS for Windows, release 9.0. The data obtained in the healthy individuals were log transformed to calculate the 2.5 and 97.5 percentiles of the reference range. Dependent upon the parameter under investigation, individual patient values either below or above those percentiles is indicated. Differences in microparticle numbers between the groups of patients and healthy individuals were tested with the Mann Whitney U test. Correlations were determined with the Spearman's Rho test.

\section{Results}

\subsection{Flow-cytometry}

Number and cellular origin of microparticles in patients with MODS and sepsis

A representative flow cytometric analysis of MP circulating in a patient is presented in figure 1. The patient plasma mainly contained platelet- and erythrocyte derived MP, but also MP from endothelial cells (EMP) and granulocytes (GMP). For the detection of EMP, antibodies directed against E-selectin and VE-Cadherin (CD62e and CD144, respectively) were used. Also TF (CD142) was measured. 
Table 2. Numbers and cellular origin of circulating MP in patients with MODS and sepsis ( $\mathrm{n}=9)$ and healthy individuals $(\mathrm{n}=14)$.

\begin{tabular}{llllll}
\hline & Marker & Patients & Controls & $\mathrm{N}_{\mathrm{x}} / \mathrm{N}_{\mathrm{t}}{ }^{3}$ & $P$ \\
\hline Platelets & CD61 & $114(65-208)^{1}$ & $237(116-547)^{1}$ & $3 / 9$ (lower) & $0.001^{1}$ \\
& & $50(17-185)^{2}$ & $126(32-381)^{2}$ & $2 / 9$ (lower) & $0.005^{2}$ \\
Erythrocytes & Glyco A & $24(<5-165)$ & $28(13-46)$ & $4 / 9$ (higher) & 0.174 \\
& & $94(26-293)$ & $46(19-84)$ & $4 / 9$ (higher) & 0.021 \\
Endothelial cells & CD62e & $93(57-309)$ & $336(87-721)$ & $2 / 9$ (lower) & 0.010 \\
& & $17(8-66)$ & $14(<5-42)$ & $1 / 9$ (higher) & 0.238 \\
Granulocytes & CD66b & $12(<5-145)$ & $<5$ & $5 / 9$ (higher) & $<0.001$ \\
& & $43(<5-110)$ & $<5$ & $8 / 9$ (higher) & $<0.001$ \\
(TF-positive) & \multirow{2}{*}{ (CD142) } & $14(5-30)$ & $47(15-108)$ & $4 / 9$ (lower) & 0.001 \\
& & $16(<5-36)$ & $20(11-49)$ & $1 / 9$ (lower) & 0.238 \\
\hline
\end{tabular}

${ }^{1}$ Cell-marker- or TF-positive and annexin V-positive MP (x10 $\left./ 1\right) ;{ }^{2}$ Cell-marker- or TF positive and annexin $\mathrm{v}$ negative MP $\left(\mathrm{x} 10^{6} / 1\right) ; \mathrm{N}_{\mathrm{t}}^{3}$ : total number of patient samples tested, $\mathrm{N}_{\mathrm{x}}$ : number of patient samples with microparticle numbers below the 2.5 or above the 97.5 percentile of the reference range in the healthy controls.

A similar analysis of a healthy individual is presented in figure 2. Here, the absence of GMP and the higher number of PMP are noteworthy. Remarkably, a larger number of EMP were measured with the anti-CD62e antibody as compared to the anti-CD144 antibody in both patients and healthy controls (Figures 1 and 2, respectively).

Quantitative data are presented in table 2, in which not only MP numbers of the marker- or TFpositive and annexin $\mathrm{V}$ positive populations are summarized (upper right quadrants of Figures 1 and 2), but also annexin V negative events that were marker- or TF-positive (lower right quadrants of Figures 1 and 2). On average, the numbers of annexin V positive MP of platelet origin were decreased and those of endothelial cell origin either decreased (CD62e) or similar (CD144). The numbers of erythrocyte derived MP were similar and the numbers of GMP were elevated. The numbers of annexin V negative PMP were decreased, EMP were comparable and the numbers of erythrocyte derived MP and GMP were increased. Figure 3 shows the numbers of PMP, erythrocyte derived MP, EMP and GMP in the individual patients. The number of annexin $\mathrm{V}$ and TF positive MP, not specified per cell type, was reduced in the patient group, but numbers of annexin $\mathrm{V}$ negative and TF positive MP were equal for this antigen. There was a considerable overlap in the ranges of the number of MP between the healthy volunteers and the patients, but, dependent upon the cellular origin of the MP, 0 to 8 of the patients had numbers of MP below the 2.5 or above the 97.5 percentile of the range in the healthy controls (Table 2). MP of T helper cells (CD4), T suppressor cells (CD8), B-cells (CD20) and plasma cells (CD38) were below the detection limit in both patients and controls (data not shown). 


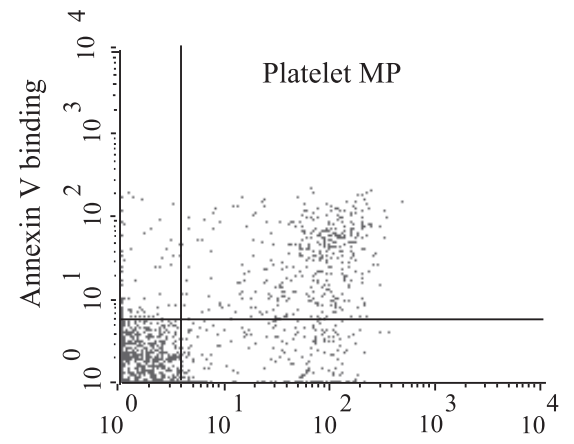

Anti-CD61 binding
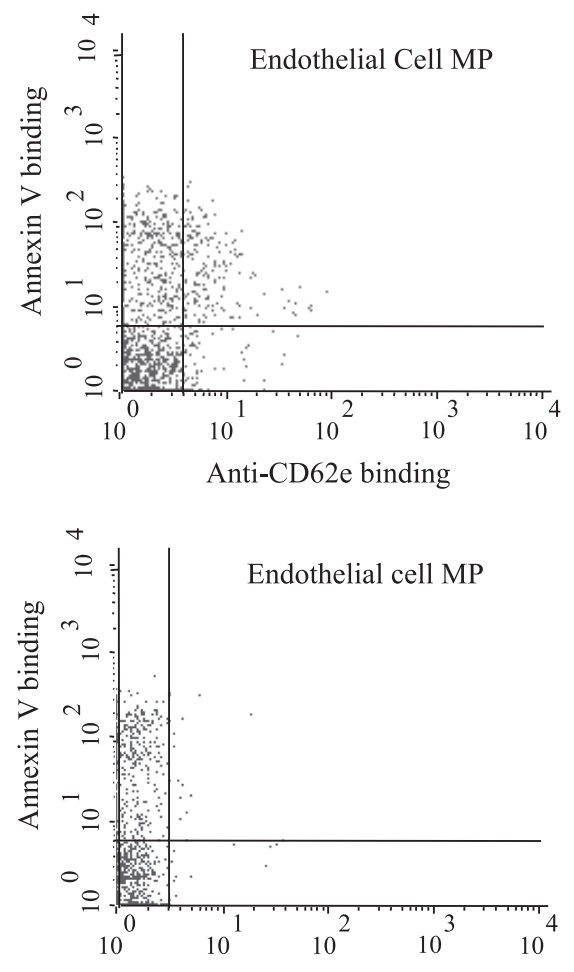

Anti-CD144 binding

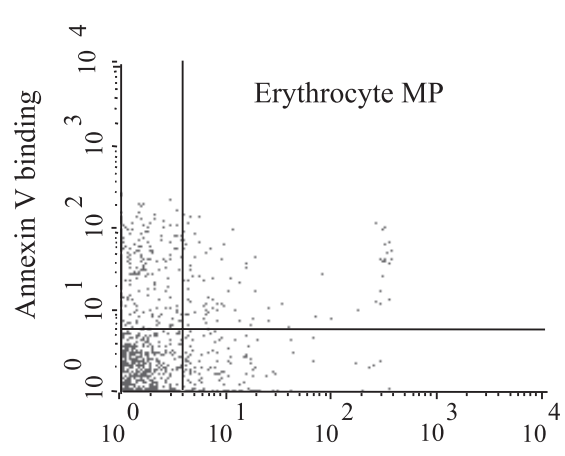

Anti-glycophorin A binding
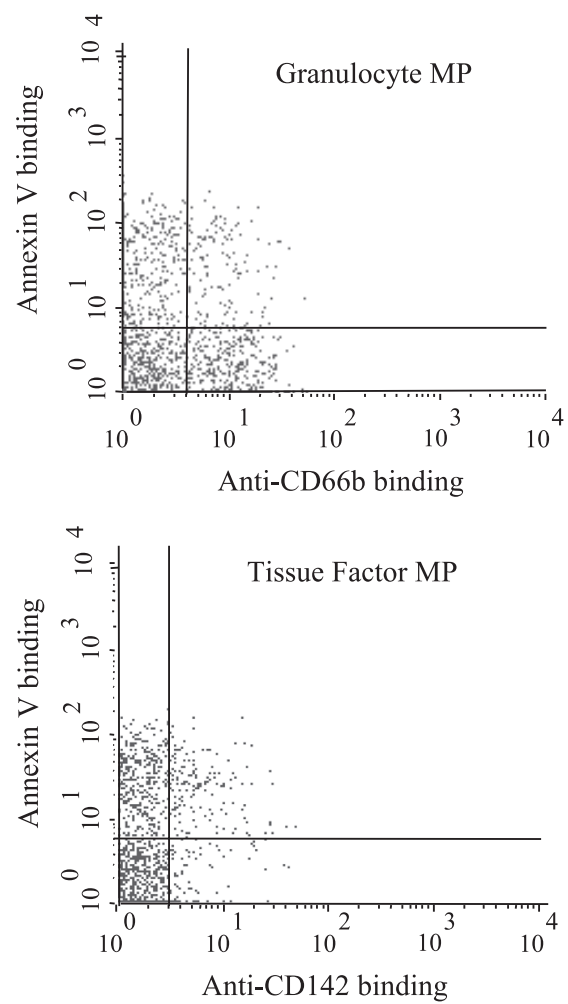

Figure 1. Representative dot plots of MP in plasma of a patient with MODS and sepsis. MP were isolated, double labeled with annexin V (PE-labeled) and a MoAb directed against a specific cell marker or TF (both FITClabeled), and analyzed by flow-cytometry as described in the Patients and Methods section. The binding of annexin $\mathrm{V}$ is indicated on the $\mathrm{y}$-axis, and the expression of the cell marker on the $\mathrm{x}$-axis. The fluorescence thresholds were set as described in the Patients and Methods section, i.e., with a isotype-identical control antibody for the cell marker and in the absence of annexin $\mathrm{V}$ for annexin $\mathrm{V}$ binding. Data of patient 7 is presented. 

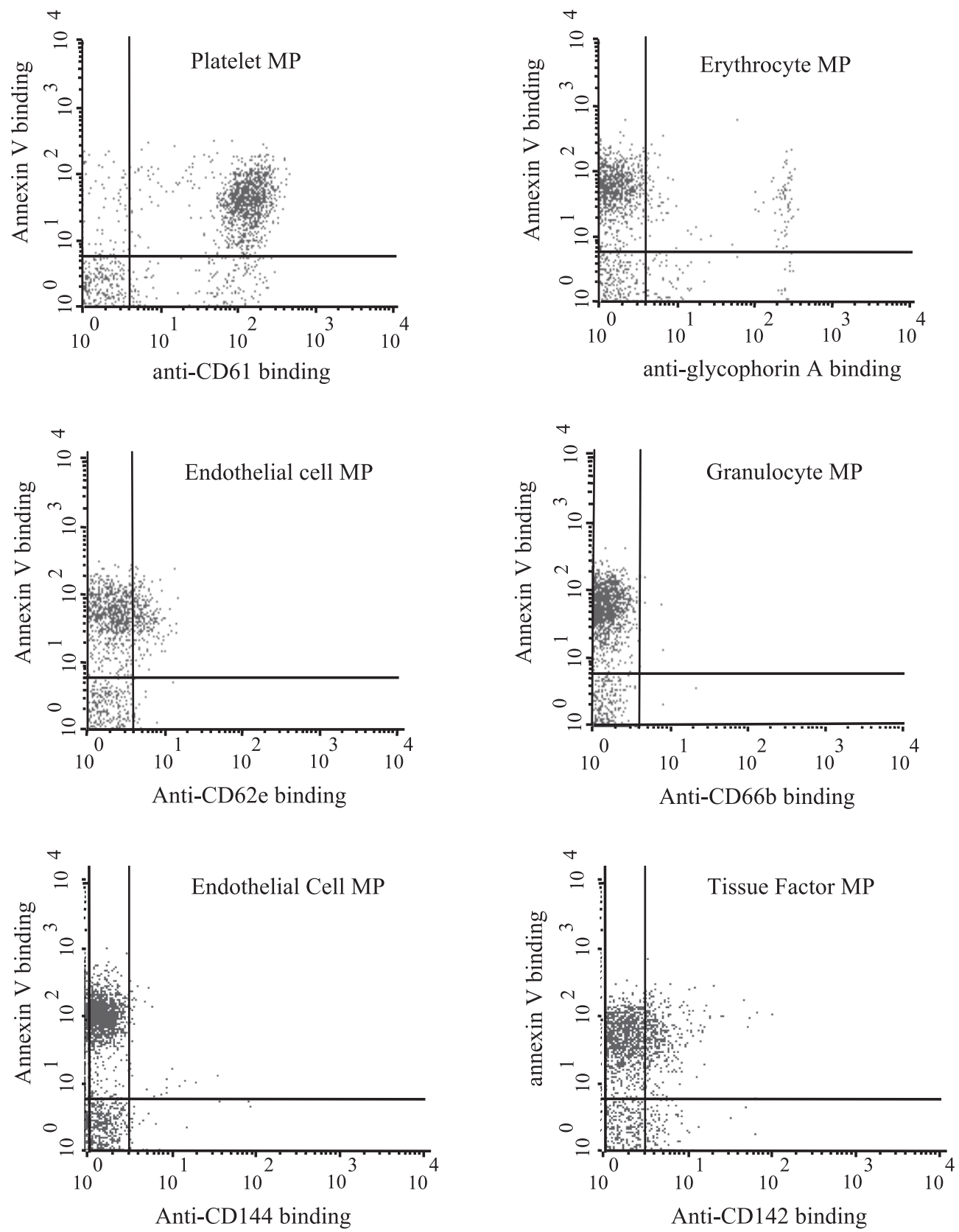

Figure 2. Representative dot plots of MP in plasma of a healthy individual. For details see legend figure 1. 

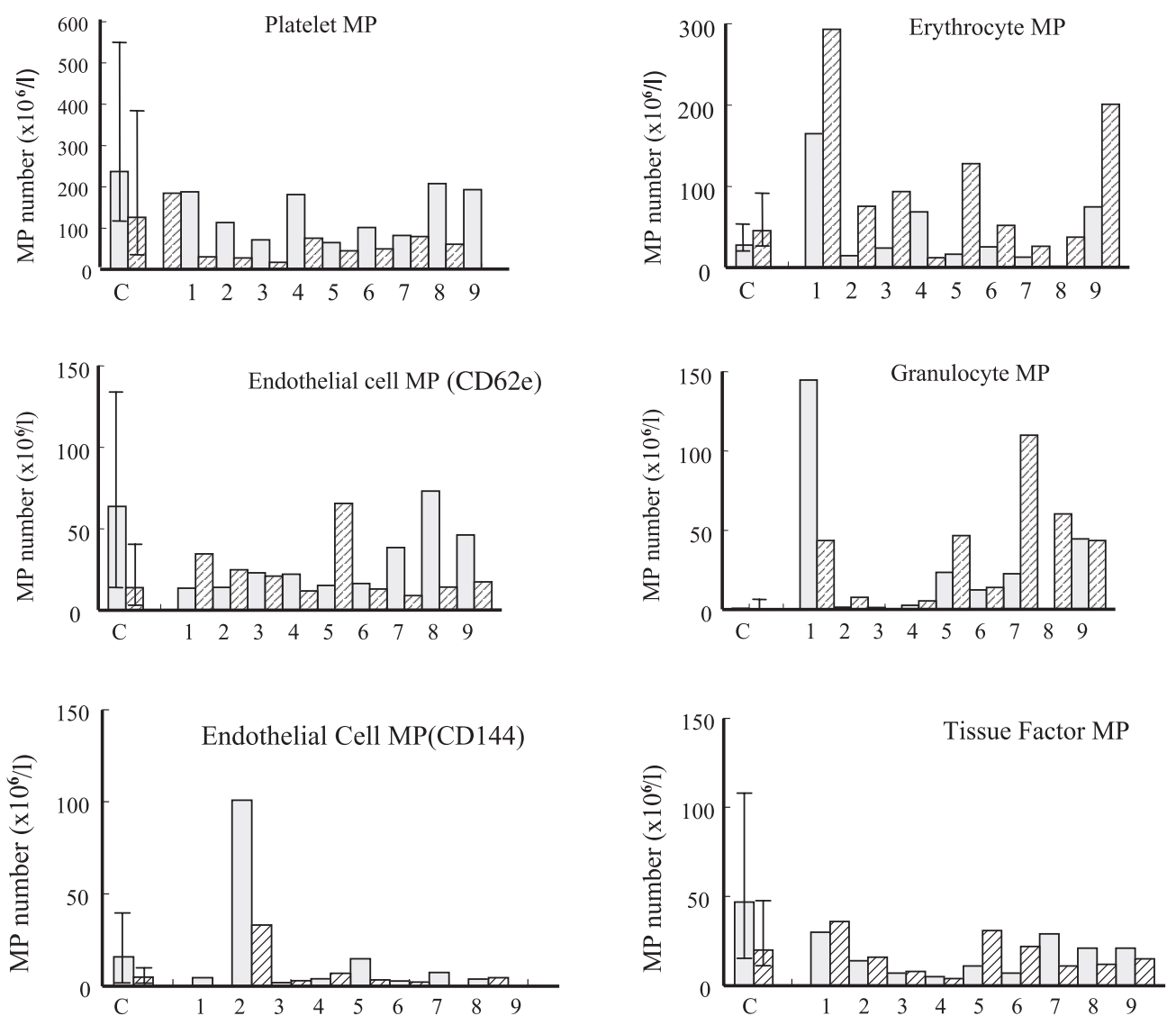

Figure 3. Microparticle numbers in the individual patients. Numbers of platelet-, erythrocyte-, endothelial-, granulocyte derived MP are shown as well as the number of TF-positive MP (x106/1 plasma). For each individual patient the numbers of marker- and annexin $\mathrm{V}$ positive (light gray bars) as well as marker positive but annexin V negative MP (hatched bars) are shown. The data in the healthy controls are depicted as median with range.

Thrombin generating capacity, initiation pathways and relation to in vivo coagulation activation status

\subsection{Thrombin generation}

Figure 4 shows thrombin generation curves obtained with MP from two patients and a representative healthy individual in the absence and presence of inhibitory MoAb. The curves from patients 1 and 7 are provided, because patient 1 demonstrated extreme inhibition with antifactor XII, in contrast to patient 7.

Overall data are provided in figure 5. As represented in this figure, the thrombin generating capacity, expressed as the area under the curve in the assay, varied widely between the patients but was overall reduced compared to the controls $(\mathrm{P}=0.008)$. Thrombin generation by MP from 

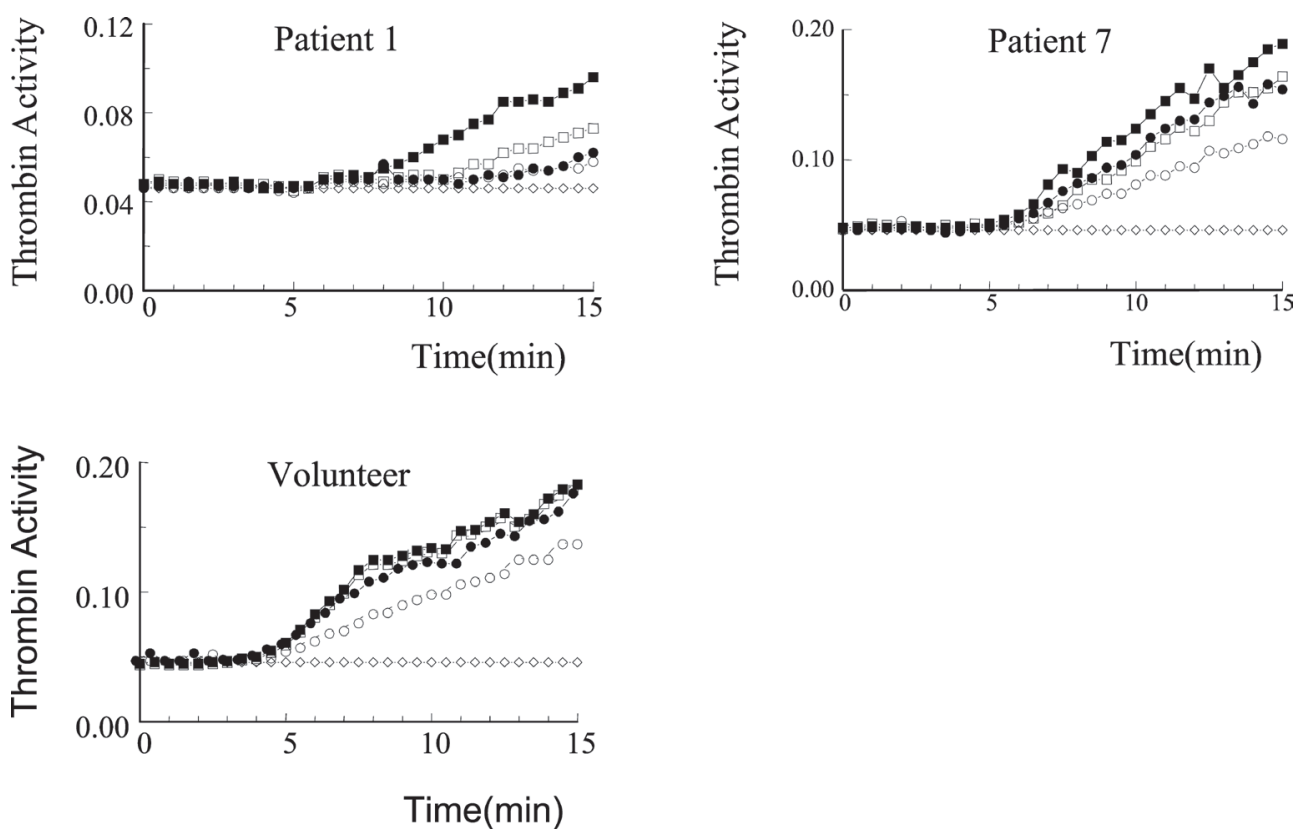

Figure 4. Thrombin generation by isolated MP from two patients and from a representative healthy individual in defibrinated normal plasma. Thrombin generation was performed in the absence (ם) or presence of antibodies to TF $(\square)$, factor XII $(\bullet)$ or factor XI $(\bigcirc)$, as described in Patients and Methods. The background, i.e. recalcified MP-free plasma, is depicted by $(\diamond)$.

healthy individuals was on average not inhibited by anti-TF, slightly inhibited by anti-factor XII (on average 12\%) and by anti-factor XI (36\%). Three patients had a significantly reduced thrombin generation capacity of the MP; four had an increased inhibition by anti-TF, two by anti-factor XII and all but one of the nine with anti-factor XI (Figure 5).

\subsection{Congulation activation status}

In vivo coagulation activation status and relation to the number of circulating MP.

Concentrations of both $\mathrm{F} 1+2$ and TAT were determined to assess the activation status of the coagulation system in vivo. As shown in Figure 6A, concentrations of both F1+2 and TAT were significantly elevated in the patients compared to the healthy controls $(\mathrm{F} 1+2$ in patients 1.20 (median), range 0.46-3.48 and controls 0.59 (0.32-1.91), $\mathrm{P}=0.005$; TAT in patients 5.50 (2.20-14.70) and controls $1.04(0-3.63), \mathrm{P}=0.001)$, indicating that the coagulation system in the patients was activated.

Next, we determined correlations between the in vivo activation status of the coagulation system and the number of circulating MP as well as their thrombin generating potential in plasma. As 

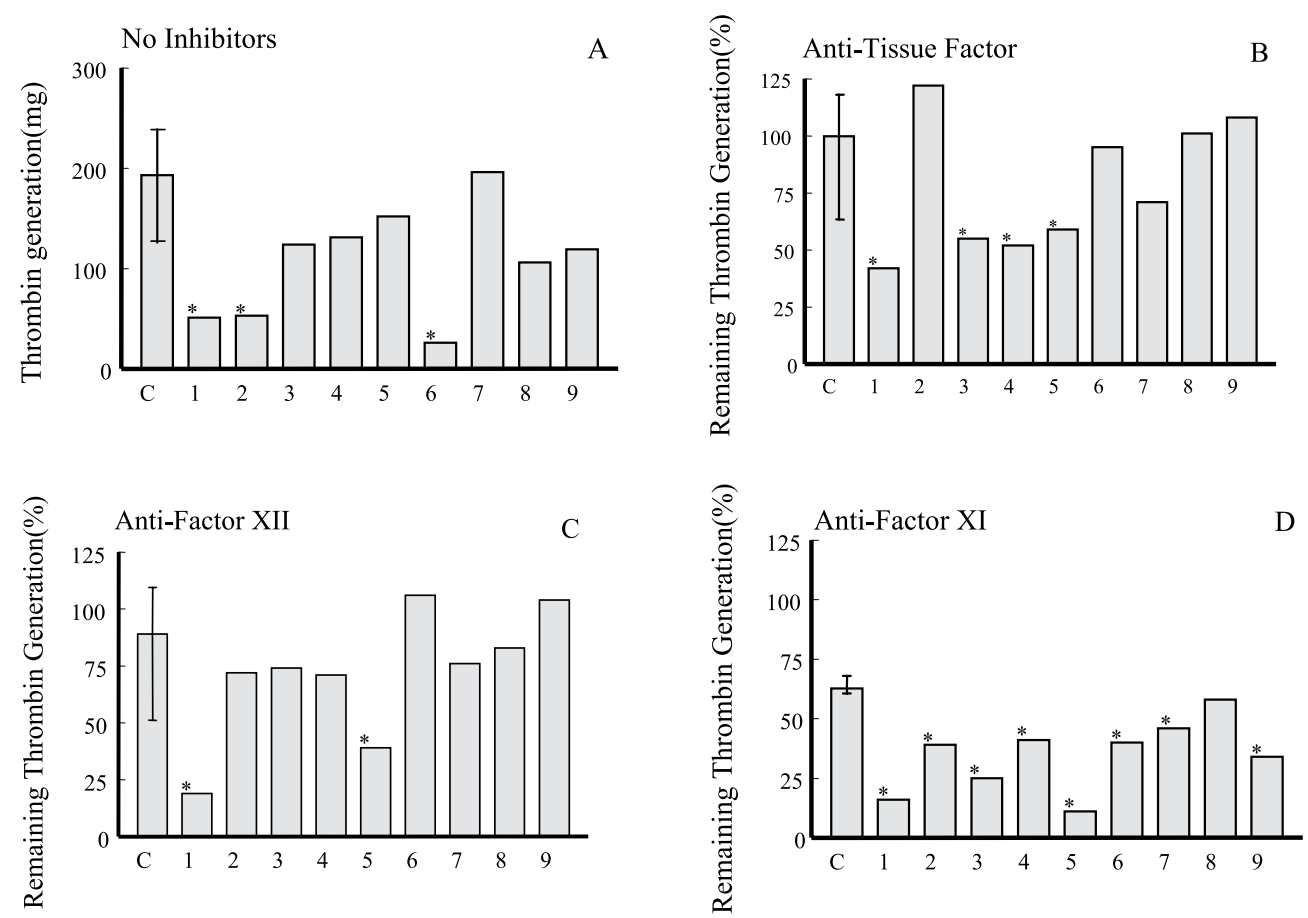

Figure 5. The effect of inhibitory antibodies on thrombin generation by MP from patients and from healthy individuals. Median and range of the data in the healthy individuals $(n=6)$ are presented, together with the individual data of patients 1-9. Note that the data in the upper left figure represent absolute values of thrombin generation, expressed as the area under the curve $(\mathrm{mg})$. Those in the other figures are relative values, i.e. the percentage remaining thrombin generation in the presence of the antibody compared to the uninhibited value in that patient. The * indicates findings lower than the 2.5 percentile of the reference range in the healthy controls.

shown in figure $6 \mathrm{~B}$ and $6 \mathrm{C}$, the numbers of circulating, annexin $\mathrm{V}$ binding $\mathrm{MP}$ in patients and controls inversely correlated with the concentrations of both $\mathrm{F} 1+2$ and TAT $(r=-0.51, \mathrm{P}=0.013$, and $\mathrm{r}=-0.65, \mathrm{P}=0.001$, respectively). A negative correlation trend was present between the thrombin generation capacity (area under curve) and TAT ( $\mathrm{r}=-0.43, \mathrm{P}=0.106)$, and a significant negative correlation of this capacity with $\mathrm{F} 1+2$ ( $\mathrm{r}=-0.62, \mathrm{P}=0.013$, figure $6 \mathrm{D})$.

\subsection{Inflammatory response and relation to circulating MP}

To assess the extent of the inflammatory response in the patients, plasma concentrations of the cytokine IL-6, the acute phase reactant CRP and the granulocyte product elastase were determined. Figure 7 (A-C) shows the individual concentrations in each patient and median plus range values in the healthy controls. The plasma concentrations of IL-6 and CRP were clearly elevated in all patients as expected. Elastase concentrations were also above the 97.5 percentile of the control range in 6 out of 9 patients. The number of GMP found in patient plasma samples correlated with their plasma elastase concentrations ( $r=0.70, P=0.036$; Figure $7 D$ ), but not with the concentrations of CRP ( $\mathrm{r}=0.05, \mathrm{P}=0.898)$ or IL-6 ( $\mathrm{r}=-0.14, \mathrm{P}=0.787)$. 

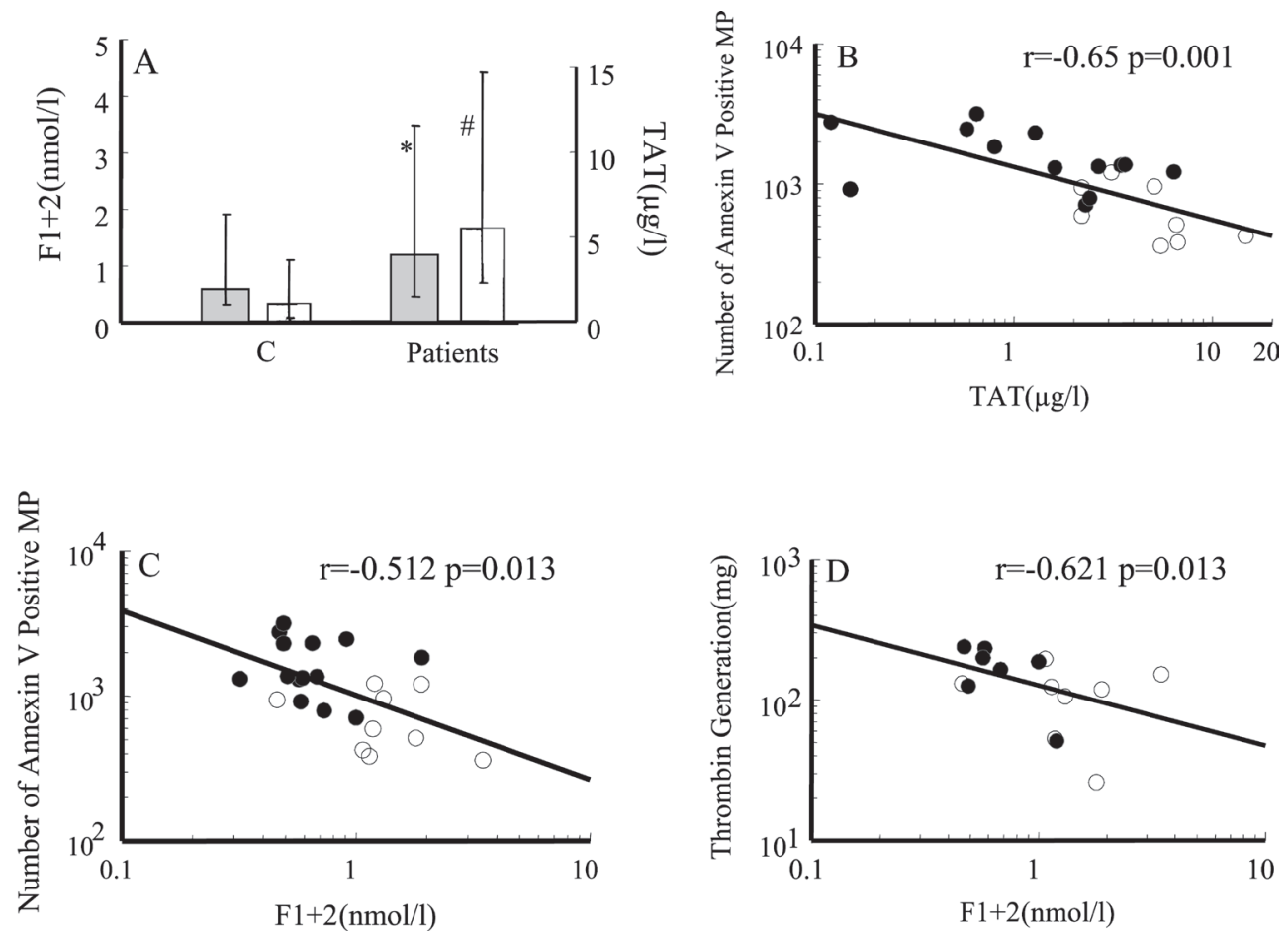

Figure 6. Relationship between in vivo thrombin generation and number and thrombin generating capacity of circulating MP. A. Median and range of concentrations of prothrombin fragment F1+2 (gray bars) and TAT (white bars) from patients $(n=9)$ and controls $(C ; n=14)$. B. Correlation between the number of circulating, annexin $\mathrm{V}$ positive MP and plasma TAT concentrations. C. Correlation between the number of circulating MP and the plasma F1+2 concentrations. D. Correlation between the extent of thrombin generation by the MP and plasma concentrations of $\mathrm{F} 1+2$. Patients are depicted as $\bigcirc$ and controls as in figures 5B-D, $* \mathrm{P}<0.05$ and $\# \mathrm{P}<0.001$ are indicated in figure 5A. Spearman's rank correlation analysis is provided in figures $5 \mathrm{~B}-\mathrm{D}$. Two of the controls are not depicted in figure $5 \mathrm{~B}$, because their plasma concentration of TAT was below $0.1 \mu \mathrm{g} / 1$.

\section{Discussion}

The present study shows that patients with MODS and sepsis have relatively low numbers of circulating MP. Reconstitution of these MP in normal plasma evoked less thrombin generation than MP from controls, and the mechanisms of thrombin formation clearly differed from healthy individuals.

Coagulation in vivo is generally believed to be initiated by the complex of TF-alpha and factor $\mathrm{VIIa}^{25}$, which results in the conversion of prothrombin (factor II) -via factor X(a)- into active thrombin (factor IIa). There is extensive evidence supporting the relevance of this coagulation activation pathway in vivo: (i) the bleeding tendency in persons with hereditary deficiencies, (ii) infusion of activated factor VII into baboons increases the concentrations of the activation peptides of factors IX, X and II, which increases are blocked by infusion of anti TF-alpha ${ }^{26}$, 

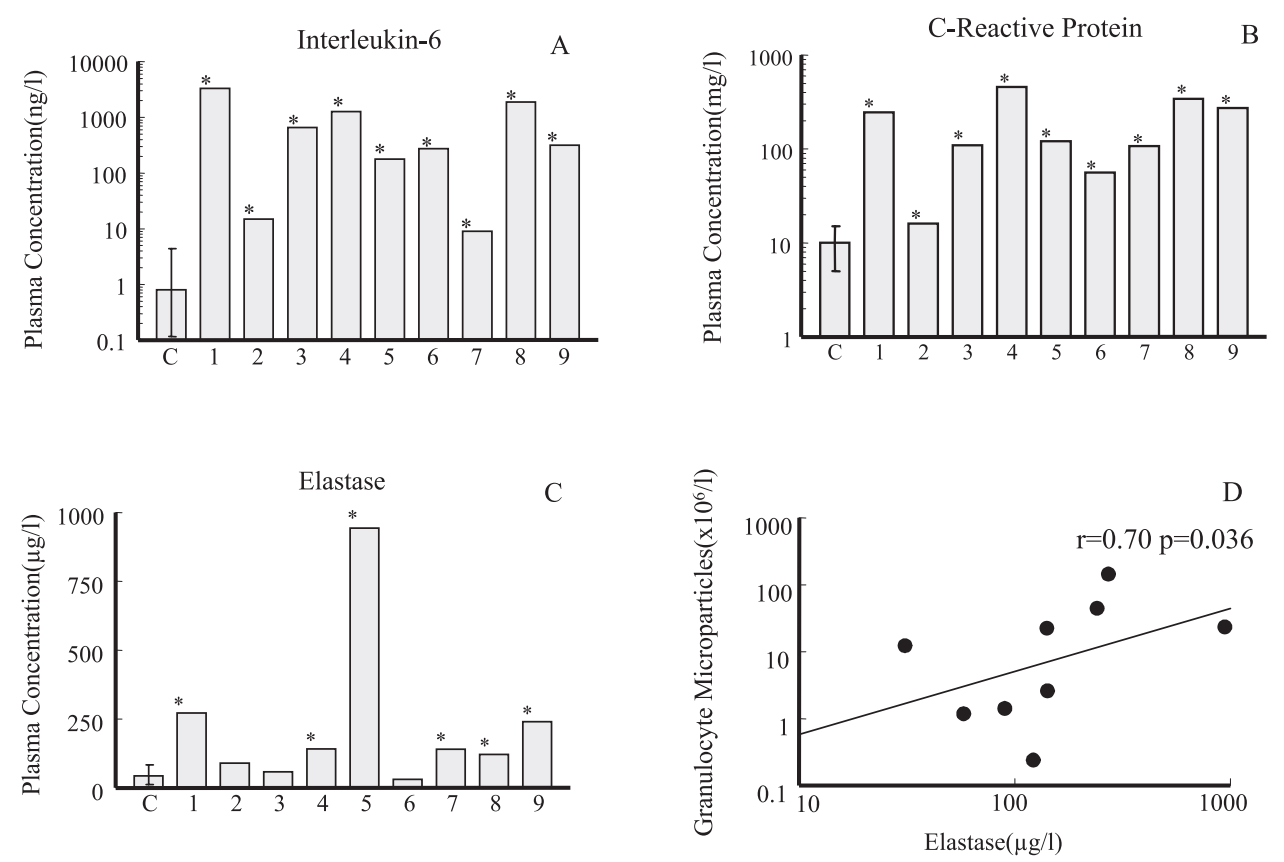

Figure 7. Inflammatory response and relation to GMP. Median and range of the data in the healthy individuals $(n=14)$ are presented, together with the individual data of patients $1-9$. Plasma concentrations of A. IL-6, B. CRP, C. Elastase and D. Correlation between the number of GMP and plasma concentration of elastase

and (iii) infusion of anti TF-alpha prevents the development of DIC in baboons that receive lethal doses of E. coli $^{28}$. In our previous studies we also found that thrombin generation induced by MP, isolated from either material of the pericardial cavity of patients undergoing cardiopulmonary bypass ${ }^{18}$ or from the systemic circulation of a patient with meningococcal septic shock and DIC ${ }^{17}$, occurred via a TF-alpha/factor VII(a) dependent mechanism. In the present study, however, anti-TF-alpha partially inhibited thrombin generation in only four patients. In two patients, thrombin generation was strongly inhibited by anti-factor XII, which in our previous studies was completely ineffective ${ }^{17,18}$, despite the fact that this antibody completely blocks kaolin-induced generation of thrombin in normal plasma ${ }^{19}$. The role of factor XII in coagulation is still obscure. Patients with hereditary factor XII deficiency do not have a bleeding tendency ${ }^{29,30}$ and administration of anti-factor XII does not prevent the development of DIC in baboons after administration of lethal doses of E. coli ${ }^{27}$. Our present findings suggest that MP can activate factor XII. Whether this factor XII-activating property is explained by differences in composition or cellular origin of the MP remains to be determined. We can only speculate on the cellular origin of the MP involved in activation of factor XII. Factor XII is present on the neutrophil membrane surface ${ }^{27,31,32}$. Interestingly, the two patients that showed by far the strongest inhibition of thrombin generation by anti-factor XII (patients 1 and 5) also had the highest numbers of GMP and the highest plasma elastase concentrations of the nine patients 
studied. A relation between the GMP and the factor XII activation in an in vitro thrombin generation assay could therefore be hypothesized.

In eight of the nine patients, anti-factor XI MoAb strongly inhibited thrombin generation, more than observed with the healthy controls. The role of factor XI in coagulation, as with factor XII, has long been debated. Patients with hereditary factor XI deficiencies suffer in various extents from bleeding abnormalities ${ }^{33}$. Factor XI can be activated by factor XIIa and by thrombin ${ }^{34}$. Once activated, factor XIa induces more extensive thrombin formation -via factors IXa and Xa- and then also indirectly inhibits fibrinolysis in plasma ${ }^{35}$. Factor XI can be activated on the platelet surface in the absence of factor $\mathrm{XII}^{36}$. Despite the fact that in patients the numbers of PMP were decreased, they still comprise about $40 \%$ of the total number of circulating MP and possibly provide an efficient surface for activation of factor XI. Platelets contain a unique form of factor XI, platelet factor XI, which is an alternative splicing product of the plasma factor XI gene $^{37}$ and which is present on the platelet surface ${ }^{38}$. To our knowledge, it is unknown whether platelet factor XI and plasma factor XI differ in their sensitivity for activation via either factor XIIa or thrombin. It is equally unknown whether MP differentially causes activation of plasma and platelet factor XI.

Development of MODS may be due to hypercoagulation and platelet deposition, leading to obstruction of blood vessels and finally organ dysfunction ${ }^{39}$. The platelet count in the patients was significantly lower than in the controls (patients $121 \times 10^{6} / 1$ (median), range 54-223; controls $238 \times 10^{6} / 1$, range 172-276; $\mathrm{P}<0.01$ ), whereas the numbers of PMP per platelet were comparable $(\mathrm{P}=0.477)$. This could suggest that the number of PMP in the circulation of patients and healthy individuals are simply a reflection of the number of platelets. Alternatively, the low numbers of PMP in the patients may be due to deposition of platelets- and/or PMP in the organs ${ }^{24,40}$. Deposition of PMP has been observed in the microvasculature after porous balloon delivery ${ }^{41}$ and in atherosclerotic plaques ${ }^{42}$.

The numbers of PMP found in the controls in the present study $\left(237 \times 10^{6} / 1\right)$ are much higher than those reported previously by us $\left(41 \times 10^{6} / 1\right)^{17}$. In the earlier study, we used EDTA-anticoagulated plasma that had been frozen and stored for 5-9 years at $-70^{\circ} \mathrm{C}$ but that had not been snap frozen prior to storage, whereas in the present study citrate anticoagulated plasma was used that had been snap frozen in liquid nitrogen and that was used within 1-2 months. This implies that absolute numbers of cell-derived MP are likely to be dependent on conditions of collection and storage. However, especially the snap freezing of the plasma aliquots was noted to be important to reliably quantify MP. It emphasizes that appropriate samples from healthy controls should always be included in clinical studies, and conditions of collection, preparation and storage carefully noted in manuscripts. 
In the present study the number of EMP in the healthy controls using the anti-E-selectin antibody $\left(64 \times 10^{6} / 1\right)$ is also much higher then in our previous report $\left(18 \times 10^{6} / 1\right)$. The detection of EMP is cumbersome due to the lack of appropriate antibodies. Combes et al. used antibodies directed against PECAM-1 and $\alpha_{v} \beta_{3}$, i.e. non-endothelial cell specific antibodies ${ }^{20}$. We used an antibody directed against E-selectin (CD62e), a protein only expressed on activated endothelial cells. This antibody was titrated on MP that strongly expose E-selectin, i.e. MP isolated from IL-1 $\alpha$ stimulated human umbilical vein endothelial cells, to ensure a proper antibody concentration. Compared to IgG control antibody staining, MP bound this anti-E-selectin antibody although their fluorescence intensity was just above the fluorescence threshold of the IgG control. Although these MP may expose E-selectin, we question their endothelial cell origin. Very recently, we obtained plasma samples from 12 patients with SLE, and found subpopulations of MP strongly binding anti-E-selectin in 3 patients. Staining with an antibody directed against VE-cadherin (CD144), like E-selectin a protein expressed only by endothelial cells, also showed a strong staining of a microparticle subpopulation in only these three patients, thus confirming their endothelial cell origin (data not shown). The anti CD144 data therefore seem more reliable than the anti-E-selectin data to estimate the number of EMP.

The numbers of annexin $\mathrm{V}$ positive EMP and those exposing TF were also reduced compared to controls, possibly via similar mechanisms as stated above. GMP (CD66b) were absent in plasma samples in healthy controls, but clearly present in the patients. By far the highest number of GMP did not stain for annexin V. The presence of these solely marker-positive events seems specific, since they are entirely absent in control plasma samples. At present, one can only speculate about the function and genesis of these distinct subpopulations. Only the CD66b- and annexin $\mathrm{V}$ positive population correlated with elevated levels of elastase $(r=0.70, \mathrm{P}=0.036)$, and not the annexin $\mathrm{V}$ negative population $(\mathrm{r}=0.41, \mathrm{P}=0.273)$, but we presume both populations to originate from granulocytes. Previously, we reported circulating GMP in patients with meningococcal septic shock ${ }^{17}$ and the present study demonstrates that GMP are not restricted to those patients. The plasma concentrations of IL-6, CRP and elastase were elevated in (almost) all patients, but only elastase correlated to the number of GMP, strengthening the observation that circulating GMP indeed reflects activation of granulocytes in the circulation.

The MP fractions from patients, containing MP of various cellular origins, generated on average less thrombin in normal plasma than MP from controls. Patients, however, clearly had enhanced coagulation activation in vivo, as reflected by increased concentrations of F1+2 and TAT, and an inverse correlation was present between the numbers of MP and plasma TAT concentrations. This apparent discrepancy between thrombin generation in vitro and enhanced coagulation in vivo may be explained in two ways. First, the more extensive inhibition of the MP-induced thrombin generation by anti-factor XI may indicate that the MP in the patients, although present in low numbers, are in some way more capable of supporting the XI loop of coagulation activation ${ }^{43,44}$. Similarly, the extensive inhibition by anti-factor XII and anti-TF in 2 and 4 patients, respectively, points to different coagulation activation properties of the MP 
in the patients versus healthy individuals. Second, (increased) adherence of MP to endothelial cells, monocytes or other circulating blood cells, resulting in a reduction of their circulating numbers, may initiate expression and production of TF-alpha and cytokines. In vitro, leukocyte MP stimulates endothelial cells to produce TF-alpha and IL- $6{ }^{45}$, whereas PMP can stimulate monocytes ${ }^{46}$. As a consequence, the production of, for instance, TF-alpha by target cells would result in enhanced coagulation activation in vivo and its reported TF-alpha dependence ${ }^{25-28}$.

Taken together, the present study shows that in patients with MODS and sepsis the circulating numbers of MP are relatively low, and differ in cellular origin from those in healthy controls. These patient MP initiate thrombin generation via different mechanisms from those described previously for MP in pericardial blood of patients undergoing cardiopulmonary bypass and patients with meningococcal sepsis.

\section{Acknowledgements}

We would like to thank Mrs. Dr. A.T. Bernards for the inclusion of patients. 


\section{References}

1 Sims P.J., Faioni E.M., Wiedmer T., Shattil S.J. Complement proteins C5b-9 cause release of membrane vesicles from the platelet surface that are enriched in the membrane receptor for coagulation factor $\mathrm{Va}$ and express prothrombinase activity. J Biol Chem 1988; 263:18205-18212.

2 Sims P.J., Wiedmer T., Esmon C.T., Weiss H.J., Shattil S.J. Assembly of the platelet prothrombinase complex is linked to vesiculation of the platelet plasma membrane. Studies in Scott syndrome: an isolated defect in platelet procoagulant activity. J Biol Chem 1989; 264:17049-17057.

3 Hoffman M., Monroe D.M., Roberts H.R. Coagulation factor IXa binding to activated platelets and platelet-derived microparticles: a flow cytometric study. Thromb Haemost 1992; 68:74-78.

4 Gilbert G.E., Sims P.J., Wiedmer T., Furie B., Furie B.C., Shattil S.J. Platelet-derived microparticles express high affinity receptors for factor VIII. J Biol Chem 1991; 266:17261-17268.

5 Satta N., Toti F., Feugeas O., Bohbot A., Dachary-Prigent J., Eschwege V., Hedman H., Freyssinet J.M. Monocyte vesiculation is a possible mechanism for dissemination of membrane-associated procoagulant activities and adhesion molecules after stimulation by lipopolysaccharide. J Immunol 1994; 153:3245-3255.

6 Kagawa H., Komiyama Y., Nakamura S., Miyaka T., Miyazaki Y. Expression of functional tissue factor on small vesicles of lipopolysaccharide-stimulated human vascular endothelial cells. Thromb Res 1998; 91:297-304.

7 Allan D., Thomas P., Limbrick A.R. The isolation and characterization of $60 \mathrm{~nm}$ vesicles ('nanovesicles') produced during ionophore A23187-induced budding of human erythrocytes. Biochem J 1980; 188:881-887.

8 Nomura S., Shouzu A., Omoto S., Hayakawa T., Kagawa H., Nishikawa M., Inada M., Fujimura Y., Ikeda Y., Fukuhara S. Effect of cilostazol on soluble adhesion molecules and platelet-derived microparticles in patients with diabetes. Thromb Haemost 1998; 80:388-392.

9 Nomura S., Suzuki M., Katsura K., Xie G.L., Miyazaki Y., Miyake T., Kido H., Kagawa H.F.S. Platelet-derived microparticles may influence the development of atherosclerosis in diabetes mellitus. Atherosclerosis 1995; 116:235-240.

10 George J.N., Pickett E.B., Saucerman S., McEver R.P., Kunicki T.J., Kieffer N., Newman P.J. Platelet surface glycoproteins. Studies on resting and activated platelets and platelet membrane microparticles in normal subjects and observations in patients during adult respiratory distress syndrome and cardiac surgery. J Clin Invest 1986; 78:340-348.

11 Katopodis J.N., Kolodny L., Jy W., Horstman L.L., De Marchena E.J., Tao J.G., Haynes D.H., Ahn Y.S. Platelet microparticles and calcium homeostasis in acute coronary ischemias. Am J Hematol. 1997; 54:95-101.

12 Warkentin T.E., Hayward C.P.M., Boshkov L.K., Santos A.V., Sheppard J.A.I., Bode A.P., Kelton J.G. Sera from patients with heparin-induced thrombocytopenia generate platelet-derived microparticles with procoagulant activity: an explanation for the thrombotic complications of heparin-induced thrombocytopenia. Blood 1994; 84:3691-3699.

13 Lee Y.J., Jy W., Horstman L.L., Janania J., Reyes Y., Kelley R.E., Ahn Y.S. Elevated platelet microparticles in transient ischemic attacks, lacunar infarcts, and multiinfarct dementias. Thromb Res 1993; 72:295-304.

14 Nomura S., Shouzu A., Nishikawa M., Kokawa T., Yasunaga K. Significance of platelet-derived microparticles in uremia. Nephron 1993; 63:485.

15 Jy W., Horstman L.L., Arce M., Ahn Y.S. Platelet microparticles in ITP. J Lab Clin Med 1992; 119:334345.

16 Holme P.A., Solum N.O., Brosstad F. Clinical significance of platelet-derived microvesicles: demonstration of their presence in patients suffering from disseminated intravascular coagulation (DIC). Thromb Haem 1993; 69:1198.

17 Nieuwland R., Berckmans R.J., McGregor S., Böing A.N., Romijn F.P.H.T.M., Westendorp R.G.J., 
Hack C.E., Sturk A. Cellular origin and procoagulant properties of microparticles in meningococcal sepsis. Blood 2000; 95:930-935.

18 Nieuwland R., Berckmans R.J., Rotteveel-Eijkman R.C., Maquelin K.N., Roozendaal K.J., Jansen P.G.M., ten Have K., Eijsman L., Hack C.E., Sturk A. Cell-derived microparticles generated in patients during cardiopulmonary bypass are highly procoagulant. Circulation 1997; 96:3534-3541.

19 Berckmans R.J., Nieuwland R., Böing A.N., Romijn F.P.H.T.M., Hack C.E., Sturk A. Cell-derived microparticles circulate in healthy humans and support low grade thrombin generation. Thromb. Haemost. 2001; 85:639-646.

20 Combes V., Simon A.C., Grau G.E., Arnoux D., Camoin L., Sabatier F., Mutin M. Sanmarco M., Sampol J., Dignat-George F. In vitro generation of endothelial microparticles and possible prothrombotic activity in patients with lupus anticoagulant. J Clin Invest 1999; 104:93-102.

21 Bone R.C. The sepsis syndrome. Clinics in Chest Medicine 1996; 17:175-181.

22 Dors D.M., Nuijens J.H., Huijbregts C.C.M., Hack C.E. A novel sensitive assay for functional factor $\mathrm{XII}$ based on the generation of kallikrein-C1-inhibitor complexes in factor XII-deficient plasma by glass-bound factor XII. Thromb Haemost. 1992; 67:644-648.

23 Beguin S., Lindhout T., Hemker H.C. The effect of trace amounts of tissue factor on thrombin generation in platelet rich plasma, its inhibition by heparin. Thromb Haemost 1989; 61:25-29.

24 Siljander P., Carpen O., Lassila R. Platelet-derived microparticles associate with fibrin during thrombosis. Blood 1996; 87:4651-4663.

25 Nemerson Y. Tissue factor: then and now. Thromb Haemost 1995; 74:180-184.

26 Biemond B.J., Levi M., ten Cate H., Soule H.R., Morris L.D., Foster D.L., Bogowitz C.A., van der Poll T., Büller H.R., ten Cate J.W. Complete inhibition of endotoxin-induced coagulation activation in chimpanzees with a monoclonal Fab fragment against factor VII/VIIa. Thromb Haemost 1995; 73(2):223-30.

27 Pixley R.A., de la Cadena R., Page J.D., Kaufman N., Wyshock E.G., Chang A., Taylor F.B.Jr., Colman R.W. The contact system contributes to hypotension but not disseminated intravascular coagulation in lethal bacteremia. In vivo use of a monoclonal anti-factor XII antibody to block contact activation in baboons. J Clin Invest 1993; 91:61-68.

28 Taylor F.B.Jr., Chang A., Ruf W., Morrissey J.H., Hinshaw L., Catlett R., Blick K., Edgington T.S. Lethal E. coli septic shock is prevented by blocking tissue factor with monoclonal antibody. Circ Shock 1991; 3:127-134.

29 Lämmle B., Wuillemin W.A., Huber I., Krauskopf M., Zürcher C., Pflugshaupt R., Furman M.I. Thromboembolism and bleeding tendency in congenital factor XII deficiency: a study on 74 subjects from 14 Swiss families. Thromb Haemost 1991; 65:117-121.

30 von Känel R., Wuillemin W.A., Furlan M., Lämmle B. Factor XII clotting activity and antigen levels in patients with thromboembolic disease. Blood Coag Fibrinol 1992; 3:555-561.

31 Gillis S., Furie B.C., Furie B. Interactions of neutrophils and coagulation proteins. Sem Haemath 1998; 34:336-342.

32 Henderson L.M., Figueroa C.D., Muller-Esterl W., Bhoola K.D. Assembly of contact-phase factors on the surface of the human neutrophil membrane. Blood 1998; 84:474-482.

33 Seligsohn U. Factor XI deficiency. Thromb Haemost 1993; 70:68-71.

34 Gailani D.Jr., Broze G.J. Factor XI activation in a revised model of blood coagulation. Science 1991; 253:909-912.

35 von dem Borne P.A.Kr., Meijers J.C.M., Bouma B.N. Feedback activation of factor XI by thrombin in plasma results in additional formation of thrombin that protects fibrin clots from fibrinolysis. Blood 1995; 86:3035-3042.

36 Oliver J.A., Monroe D.M., Roberts H.R., Hoffman M. Thrombin activates factor XI on activated platelets in the absence of factor XII. Arterioscler Thromb Vasc Biol 1999; 19:170-177.

37 Hsu T.C., Shore S.K., Seshsmma T., Bagasra O., Walsh P.N. Molecular cloning of platelet factor XI, an alternative splicing product of the plasma factor XI gene. J Biol Chem 1998; 273:13787-13793.

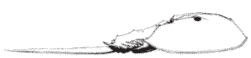


38 Hu C., Baglia F.A., Mills D.C.B., Konkle B.A., Walsh P.N. Tissue-specific expression of functional platelet factor XI is independent of plasma factor XI expression. Blood 1998; 91:3800-3807.

39 Levi M., ten Cate H. Disseminated intravascular coagulation. N Eng J Med 1999; 341:586-592.

40 Holme P.A., Solum N.O., Brosstad F., Pederson T., Kveine M. Microvesicles bind soluble fibrinogen, adhere to immobilized fibrinogen and coaggregate with platelets. Thromb Haemost 1998; 79:389-394.

41 Nasser T.K., Wilensky R.L., Mehdi K., March K.L. Microparticle deposition in periarterial microvasculature and intramural dissections after porous balloon delivery into atherosclerotic vessels: quantitation and localization by confocal scanning laser microcopy. Am Heart J 1996; 131:892-898.

42 Mallat Z., Hugel B., Ohan J., Lesèche G., Freyssinet J.M., Tedgui A. Shed membrane microparticles with procoagulant potential in human atherosclerotic plaques. Circulation 1999; 99:348-353.

43 von Segesser L.K., Turina M. Cardiopulmonary bypass without systemic heparinization. Performance of heparin-coated oxygenators in comparison with classic membrane and bubble oxygenators. J Thorac Cardiovasc Surg 1989; 98:386-396.

44 von dem Borne P.A.Kr., Mosnier L.O., Tans G., Meijers J.C.M., Bouma B.N. Factor XI activation by meizothrombin: stimulation by phospholipid vesicles containing both phosphatidylserine and phosphatidylethanolamine. Thromb Haemost 1997; 78:834-839.

45 Mesri M., Altieri D.C. Leukocyte microparticles stimulate endothelial cell cytokine release and tissue factor induction in a JNK1 signaling pathway. J Biol Chem 1999; 274:23111-23118.

46 Barry O.P., Kazanietz M.G., Praticò D., Fitzgerald G.A. Arachidonic acid in platelet microparticles up-regulates cyclooxygenase-2-dependent prostablandin formation via a protein kinase C/mitogenactivated protein kinase-dependent pathway. J Biol Chem 1999; 274:7545-7556. 



\section{CHAPTER}

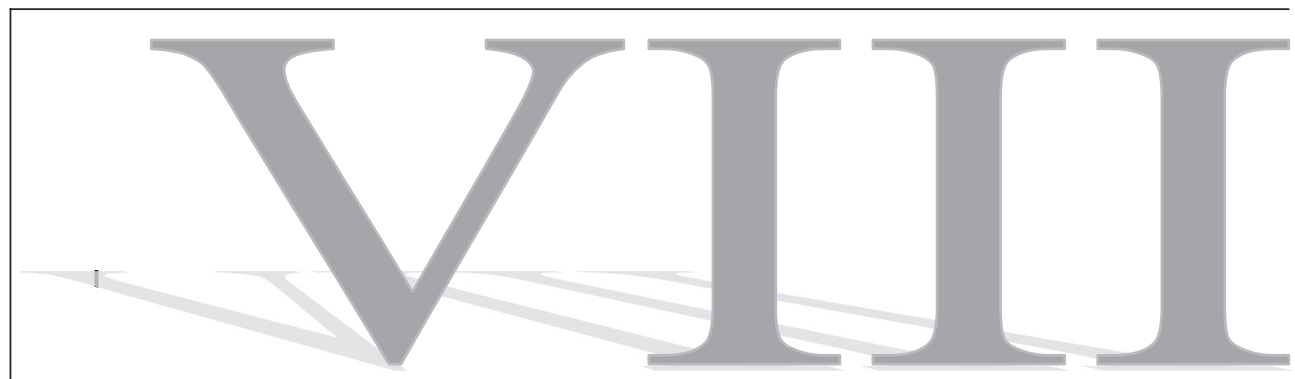

Decrease number of platelet derived microparticles in severe dengue virus infectinos with haemorrhagic tendency

K. Joop*, A.T.A. Mairuhu*, T.E. Setiati, P. Koraka, A. Soemantri, A.D.M.E. Osterhaus, D.P.M. Brandjes, A. Sturk, R. Nieuwland, H. ten Cate, A. Leyte, E.C.M. van Gorp

* Both authors contributed equally to this work.

\section{Contents chapter VIII}

1. Introduction

2. Patients and methods

3. Results

3.1 Patients characteristics

4. Discussion

5. Acknowledgements

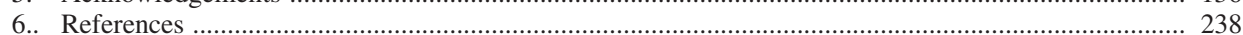




\section{Abstract}

Severe dengue virus infections are characterised by haemorrhagic manifestations. In afflicted patients, we observed a substantial decrease in platelet derived circulating microparticles with a nadir during acute illness and ongoing normalization during recovery. We suggest a causative role for platelet microparticle deficiency in dengue haemorrhagic fever. 


\section{Introduction}

Dengue is the most important of arthropod-borne viral diseases ${ }^{1}$. At present, almost $30 \%$ of the world population is at risk for dengue virus infection and this number is expected to rise ${ }^{2}$. The haemorrhagic manifestations are characteristic to severe dengue virus infections and are thought to be due to thrombocytopenia and thrombocytopathy, but recent data suggest that other abnormalities in blood coagulation and fibrinolysis may also play an important role e $^{3-5}$.

The coagulation system requires the presence of phospholipid cofactors that provide a surface to assemble the various complexes to activate clotting factors. Microparticles are small, high phosphatidylserine expressing membrane vesicles, released from cells during activation or apoptosis that have a large number of (high affinity) binding sites for components of the X-ase and prothrombinase complexes ${ }^{6-10}$. Microparticle formation is altered, most often increased, in several disease states. Higher numbers of platelet derived microparticles have been described in patients with various underlying illnesses ${ }^{11-14}$, whereas a reduced ability to generate microparticles occurs in a congenital bleeding disorder (Scott syndrome) ${ }^{15}$. The primary cause of dengue associated bleeding is not yet clear, both hyper- and hypocoagulation have been implicated. Therefore, we investigated microparticle dynamics in the course of severe dengue infection.

\section{Patients and methods}

Patients, aged 2 to 14 years, admitted to the paediatric intensive care unit and the paediatric ward of the Dr. Kariadi Hospital in Semarang, Indonesia, with a clinical diagnosis of suspected dengue haemorrhagic fever or dengue shock syndrome were included. The controls were healthy school-aged Javanese children from 6 to 13 years of age (median age 10 years) who originated from the same geographical area as the cases. The ethics committee of the Dr. Kariadi Hospital approved all clinical and laboratory aspects of this study. Blood samples were only taken from patients and controls provided that a parent or legal guardian gave informed consent. The presence of dengue was objectively confirmed by serological assays or by the detection of dengue antigen and RNA using a dot blot immunoassay and a dengue serotype reverse transcriptase PCR respectively ${ }^{16}$.

For microparticle analysis, blood samples were centrifuged within 1-2 hours after retrieval and microparticle-rich plasma was snap frozen. Microparticle analysis was performed upon thawing of the samples and preparation of microparticle suspensions, on a FACSCalibur flow cytometer with CellQuest-PRO software (Beckton Dickinson, San Jose, CA, USA), as described ${ }^{17}$. Briefly, microparticles were identified on FSC, SSC, binding of annexin V and cellspecific antibodies or anti-TF antibody (for a detailed description of the reagents and antibodies used see reference ${ }^{17}$ ). 


\section{Results}

\subsection{Patient characteristics}

Eight patients with a confirmed dengue virus infection from whom complete time series were available (day $0,1,2,7$ and 30), were randomly selected for this study. Three patients had evidence of circulatory failure on admission or during admission and were thus classified as suffering from dengue shock syndrome. One of the patients with circulatory failure had no evidence of vascular leakage and was classified as suffering from severe dengue fever. All other patients were classified as suffering from dengue fever. Platelet count was lower on days 1 and 2 compared to day of admission (day of admission: 73.000 cells $/ \mathrm{mm}^{3}$ (IQR 55.000-85.000); day 1:42.000 cells $/ \mathrm{mm}^{3}$ (IQR 32.000-57.000); day 2:59.000 cells $/ \mathrm{mm}^{3}$ (IQR 31.000-100.000)). Platelet count increased to near normal values on day 7 (168.000 cells $/ \mathrm{mm}^{3}$ (IQR 65.000297.000)). All patients survived and the median stay in the hospital was 6 days (range 3 to 8 days).

Number and time course of circulating microparticles

As shown in Table 1, on day of admission and on the first 2 days after admission the total number of microparticles in patients was decreased approximately 12-fold compared to microparticle numbers in healthy controls. Thereafter microparticle numbers gradually increased (Friedman Test: $\mathrm{P}<0.01$ ), though not yet reaching normal levels at 30 days. The tissue factor positive fraction of microparticles however was about 2-4 times higher in patients, rising from $12 \%$ (IQR 7-25) to $24 \%$ (IQR 14-60) from day of admission to day 30, than in controls (6\% (IQR 4-8)). No significant differences were observed between patients with circulatory failure and patients without circulatory failure (not shown).

Number and time course of microparticles from various cell sources

Platelet derived microparticles were identified using an anti-CD61 (GPIIIA) mAb. Absolute numbers of CD61-positive microparticles were found to be decreased with respect to the numbers in controls particularly on day of admission (more than 35-fold decrease) and on days 1 and 2 (Table 1). After day 2 absolute numbers started to increase, although not reaching normal values during 30 day follow up (Friedman Test: $\mathrm{P}<0.01$ ). Dynamics of total microparticle count were mainly explained by the initial depletion and following rise in platelet microparticle numbers.

Endothelial cell derived microparticles were identified by staining with an anti-CD62e (E-selectin) mAb. On all study days, endothelial cell derived microparticle numbers, though very low, tended to be higher in particular on day of admission and on days 7 and 30, compared to controls. In time however, endothelial cell derived microparticles did not change significantly

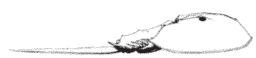


Table 1. Microparticle number in dengue virus infected patients during admission and in healthy controls.

\begin{tabular}{llllllll}
\hline Cell & Marker & Day 0 & Day 1 & Day 2 & Day 7 & Day 30 & Control \\
\hline All & Annexin V & 205 & 216 & 222 & 612 & 608 & 2530 \\
microparticles & & $(122-283)$ & $(115-332)$ & $(144-362)$ & $(323-1123)$ & $(365-1348)$ & $(2399-3184)$ \\
Endothelial & E-selectin & 10 & 1 & 2 & 14 & 5 & 1 \\
cells & (CD62e) & $(1-24)$ & $(0-5)$ & $(1-3)$ & $(0-37)$ & $(2-17)^{*}$ & $(0-2)$ \\
Platelets & GPIIIA & 50 & 62 & 73 & 455 & 431 & 1814 \\
& (CD61) & $(38-88)^{*}$ & $(36-154)^{*}$ & $(49-127)^{*}$ & $(161-927)^{*}$ & $(162-956)^{*}$ & $(1177-2319)$ \\
Erythrocytes & Glyco A & 40 & 55 & 48 & 54 & 48 & 33 \\
& & $(28-149)$ & $(29-118)$ & $(22-174)$ & $(41-80)$ & $(29-80)$ & $(18-50)$ \\
Granulocyte & CD66e & 18 & 26 & 24 & 60 & 36 & 43 \\
& & $(13-31)^{*}$ & $(12-69)$ & $(11-34)$ & $(35-136)$ & $(15-78)$ & $(25-49)$ \\
Monocyte & CD14 & 11 & 2 & 11 & 12 & 3 & 1 \\
& & $(6-20)^{*}$ & $(2-7)^{*}$ & $(5-25)^{*}$ & $(4-30)^{*}$ & $(1-21)$ & $(0-2)$ \\
B-cell & CD20 & 10 & 8 & 14 & 19 & 14 & 8 \\
& & $(7-19)$ & $(4-18)$ & $(6-29)$ & $(5-68)$ & $(7-38)$ & $(3-13)$ \\
TH-cell & CD4 & 16 & 9 & 4 & 12 & 9 & 4 \\
& & $(8-18)^{*}$ & $(3-18)$ & $(2-10)$ & $(1-24)$ & $(3-18)$ & $(1-6)$ \\
TS-cell & CD8 & $18(7-40)$ & $12(8-20)^{*}$ & $16(6-52)$ & $18(4-40)$ & $24(7-32)$ & 7 \\
& & & & & & & $(2-9)$ \\
\hline
\end{tabular}

Data are expressed as median with corresponding interquartile range and represent number x $10^{6} / 1$ plasma. $* \mathrm{P}<0.05$ (Mann-Whitney $\mathrm{U}$ test) for patients versus control

(Friedman Test: $\mathrm{P}=0.25)$. Absolute numbers of microparticles derived from monocytes (antiCD14), $\mathrm{T}_{\mathrm{H}}$-cells (anti-CD4) and $\mathrm{T}_{\mathrm{s}}$-cells (anti-CD8) were somewhat higher than endothelial microparticle numbers and appeared significantly elevated both in the first three days of admission and at day 30. The numbers of microparticles derived from erythrocytes (antiGlycophorin A mAb), granulocytes (anti-CD66e mAb) and B-cells (anti-CD20 mAb) were comparable to controls (Table 1).

\section{Discussion}

This study shows that patients with a severe dengue virus infection have a significant decrease in absolute number of circulating microparticles. The decrease was found to be mainly caused by a deficiency in platelet-derived microparticles: a more than 35-fold reduction in CD61 (GPIIIA) positive microparticles, accompanied by a modest rise in absolute numbers of microparticles originating from some other cell populations like endothelial cells, monocytes, $\mathrm{T}_{\mathrm{H}}$-cells and $\mathrm{T}_{\mathrm{s}}$-cells. The decreased numbers of microparticles originating from platelets may provide a clue to the mechanism by which Dengue virus causes a potentially fatal haemorrhagic disease.

Upon activation cells lose their asymmetric orientation of membrane phospholipids and form a procoagulant surface by exposing phosphatidylserine ${ }^{18}$. The transverse migration of phosphatidylserine generally coincides with the formation of phosphatidylserine-rich microparticles. Thus, in healthy individuals a significant number of cell derived microparticles 
has been found in the circulation that support low grade thrombin generation ${ }^{19}$. Under pathophysiological conditions, the number of microparticles is generally increased, allowing a potentially significant increase in the rate of thrombin formation by increasing the procoagulant surface. The significance of this process is illustrated in Scott syndrome, a clinical condition that is associated with a decreased surface exposure of plasma membrane phosphatidylserine and an impaired capacity to generate microparticle ${ }^{20}$. Patients typically suffer from a moderate to severe bleeding tendency and studies have demonstrated that the defect involves a protein (scramblase) which mediates the loss of membrane asymmetry with exposure of procoagulant phosphatidylserine on the outer membrane leaflet ${ }^{10,18,20}$.

Severe dengue virus infections are characterized by a haemorrhagic tendency but only moderate thrombocytopenia. In our study, median values for platelet count varied from $73.000 \mathrm{cells} / \mathrm{mm}^{3}$ on day of admission, 42.000 cells $/ \mathrm{mm}^{3}$ on the first day after admission, to $59.000 \mathrm{cells} / \mathrm{mm}^{3}$ on the second day after admission. Interestingly, platelet derived microparticle deficiency was more pronounced than the thrombocytopenia itself, and we did not find an association between platelet numbers and levels of platelet derived microparticles (Spearman's rho 0.08, $(\mathrm{P}=0.73)$ ). This suggests that microparticle production from thrombocytes (or megakaryocytes, ${ }^{31,32}$ is inhibited directly by the virus infection instead of the infection having an indirect effect via suppression of platelet production ${ }^{21-26}$.

In conclusion, our study demonstrates that Dengue virus infections may cause a near deficiency in absolute numbers of platelet-derived microparticles. Although relatively low numbers of microparticles have also been found in other acquired syndromes, this is the first report demonstrating a near deficiency of platelet-derived microparticles due to a severe infection resulting in a clinically significant haemorrhagic tendency. Although the primary mechanism that causes this deficiency remains to be determined, the decreased numbers of microparticles, especially those originating from platelets, could play an important role in dengue disease severity. The study of dengue virus associated abnormalities in microparticle number may give important insights in how viruses influence the complex coagulation cascade.

\section{Acknowledgement}

Financial support. This project was supported by a grant from the Royal Netherlands Academy of Arts and Sciences.

\section{Conflict of interest. None}

Besides the authors, the following investigators participated in this study: Indonesia: K. Djamiatun, C. Suharti, R. Djokomoeljanto (Department of Internal Medicine, dr. Kariadi Hospital, University of Diponegoro, Semarang); S.M.H. Faradz (Molecular and Cytogenetics Unit, Biotechnology Laboratory, Medical Faculty Diponegoro University, Semarang). The 
Netherlands: J.W.M. van der Meer, W.M.V. Dolmans (Department of Internal Medicine,

University Medical Center St. Radboud, Radboud University Nijmegen, Nijmegen); C.E. Hack

(Sanquin Research, Department of Immunopathology, Amsterdam; Academic Medical Center,

Laboratory for Experimental and Clinical Immunology, Amsterdam; VU Medical Center,

Department of Clinical Chemistry, Amsterdam), Y.T. van der Heide (Clinical Chemistry and

Hematology Laboratory, Slotervaart Hospital, Amsterdam); K.J. Stittelaar (Institute of Virology,

Erasmus Medical Center, Rotterdam); P. Reitsma (Laboratory for Experimental Medicine,

Academic Medical Centre, University of Amsterdam, Amsterdam). 


\section{References}

1 Rigau-Perez J.G., Clark G.G., Gubler D.J., Reiter P., Sanders E.J., Vorndam A.V. Dengue and dengue haemorrhagic fever. Lancet 1998; 9132:971-977.

2 Hales S., de Wet N., Maindonald J., Woodward A. Potential effect of population and climate changes on global distribution of dengue fever: an empirical model. Lancet 2002; 9336:830-834.

3 Krishnamurti C., Kalayanarooj S., Cutting M.A., Peat R.A., Rothwell S.W., Reid T.J., Green S., Nisalak A., Endy T.P., Vaughn D.W., Nimmannitya S., Innis B.L. Mechanisms of hemorrhage in dengue without circulatory collapse. Am J Trop Med Hyg 2001; 6:840-847.

4 van Gorp E.C., Setiati T.E., Mairuhu A.T., Suharti C., ten Cate H., Dolmans W.M., van der Meer J.W., Hack C.E., Brandjes D.P. Impaired fibrinolysis in the pathogenesis of dengue hemorrhagic fever. J Med Virol 2002; 4:549-554.

5 Wills B.A., Oragui E.E., Stephens A.C., Daramola O.A., Dung N.M., Loan H.T., Chau N.V., Chambers M., Stepniewska K., Farrar J.J., Levin M. Coagulation Abnormalities in Dengue Hemorrhagic Fever: Serial Investigations in 167 Vietnamese Children with Dengue Shock Syndrome. Clin Infect Dis 2002; 3 277-285.

6 Gilbert G.E., Sims P.J., Wiedmer T., Furie B., Furie B.C., Shattil S.J. Platelet-derived microparticles express high affinity receptors for factor VIII. J Biol Chem 1991; 26:17261-17268.

7 Hoffman M., Monroe D.M., Roberts H.R. Coagulation factor IXa binding to activated platelets and platelet-derived microparticles: a flow cytometric study. Thromb Haemost 1992; 1:74-78.

8 Holme P.A., Brosstad F., Solum N.O. Platelet-derived microvesicles and activated platelets express factor Xa activity. Blood Coagul Fibrinolysis 1995; 4:302-310.

9 Sims P.J., Faioni E.M., Wiedmer T., Shattil S.J. Complement proteins C5b-9 cause release of membrane vesicles from the platelet surface that are enriched in the membrane receptor for coagulation factor Va and express prothrombinase activity. J Biol Chem 1988; 34:18205-18212.

10 Sims P.J., Wiedmer T., Esmon C.T., Weiss H.J., Shattil S.J. Assembly of the platelet prothrombinase complex is linked to vesiculation of the platelet plasma membrane. Studies in Scott syndrome: an isolated defect in platelet procoagulant activity. J Biol Chem 1989; 29:17049-17057.

11 Jy W., Horstman L.L., Arce M., Ahn Y.S. Clinical significance of platelet microparticles in autoimmune thrombocytopenias. J Lab Clin Med 1992; 4:334-345.

12 Kelton J.G., Moore J.C., Warkentin T.E., Hayward C.P. Isolation and characterization of cysteine proteinase in thrombotic thrombocytopenic purpura. Br J Haematol 1996; 2:421-426.

13 Lee Y.J., Jy W., Horstman L.L., Janania J., Reyes Y., Kelley R.E., Ahn Y.S. Elevated platelet microparticles in transient ischemic attacks, lacunar infarcts, and multiinfarct dementias. Thromb Res 1993; 4:295-304.

14 Nomura S., Komiyama Y., Miyake T., Miyazaki Y., Kido H., Suzuki M., Kagawa H., Yanabu M., Takahashi H., Fukuhara S. Amyloid beta-protein precursor-rich platelet microparticles in thrombotic disease. Thromb Haemost 1994; 4:519-522.

15 Horstman L.L., Ahn Y.S. Platelet microparticles: a wide-angle perspective. Crit Rev Oncol Hematol 1999; 2:111-142.

16 Koraka P., Burghoorn-Maas C.P., Falconar A., Setiati T.E., Djamiatun K., Groen J., Osterhaus A.D. Detection of immune-complex-dissociated nonstructural-1 antigen in patients with acute dengue virus infections. J Clin Microbiol 2003; 9:4154-4159.

17 Sommeijer D.W., Joop K., Leyte A., Reitsma P.H., ten Cate H. Pravastatin reduces fibrinogen receptor gpIIIa on platelet-derived microparticles in patients with type 2 diabetes. J Thromb Haemost 2005; 6: 1168-1171.

18 Solum N.O. Procoagulant expression in platelets and defects leading to clinical disorders. Arterioscler Thromb Vasc Biol 1999; 12:2841-2846.

19 Berckmans R.J., Neiuwland R., Boing A.N., Romijn F.P., Hack C.E., Sturk A. Cell-derived microparticles circulate in healthy humans and support low grade thrombin generation. Thromb Haemost 2001; 4:639-646. 
20 Zwaal R.F., Comfurius P., Bevers E.M. Scott syndrome, a bleeding disorder caused by defective scrambling of membrane phospholipids. Biochim Biophys Acta 2004; 2-3:119-128.

21 Boonpucknavig S., Vuttiviroj O., Bunnag C., Bhamarapravati N., Nimmanitya S. Demonstration of dengue antibody complexes on the surface of platelets from patients with dengue hemorrhagic fever. Am J Trop Med Hyg 1979; 5:881-884.

22 La Russa V.F., Innis B.L. Mechanisms of dengue virus-induced bone marrow suppression. Baillieres Clin Haematol 1995; 1:249-270.

23 Mitrakul C., Poshyachinda M., Futrakul P., Sangkawibha N., Ahandrik S. Hemostatic and platelet kinetic studies in dengue hemorrhagic fever. Am J Trop Med Hyg 1977; 5Pt 1:975-984.

24 Oishi K., Inoue S., Cinco M.T., Dimaano E.M., Alera M.T., Alfon J.A., Abanes F., Cruz D.J., Matias R.R., Matsuura H., Hasebe F., Tanimura S., Kumatori A., Morita K., Natividad F.F., Nagatake T. Correlation between increased platelet-associated IgG and thrombocytopenia in secondary dengue virus infections. J Med Virol 2003; 2:259-264.

25 Saito M., Oishi K., Inoue S., Dimaano E.M., Alera M.T., Robles A.M., Estrella B.D.Jr., Kumatori A., Moji K., Alonzo M.T., Buerano C.C., Matias R.R., Morita K., Natividad F.F., Nagatake T. Association of increased platelet-associated immunoglobulins with thrombocytopenia and the severity of disease in secondary dengue virus infections. Clin Exp Immunol 2004; 2:299-303.

26 Wang S., He R., Patarapotikul J., Innis B.L., Anderson R. Antibody-enhanced binding of dengue-2 virus to human platelets. Virology 1995; 1:254-257. 



\section{CHAPTER}

\section{Pravastatin reduces levels of the glycoprotein IIla subunit from the fibrinogen receptor on platelet- derived microparticles in patients with type 2 diabetes}

D.W. Sommeijer, K. Joop, A. Leyte, P.H. Reitsma, H. ten Cate

\section{Contents chapter XI}

1. Introduction

2. Research design and methods

2.1 Blood sampling and laboratory methods $\ldots$

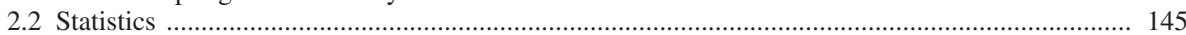

3. Results

3.1 Serum lipids and safety parameters

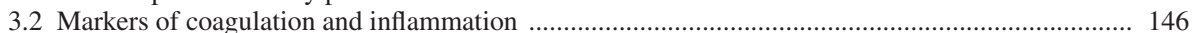

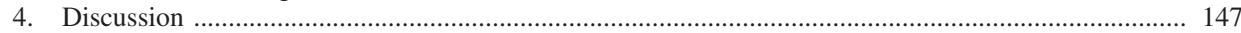

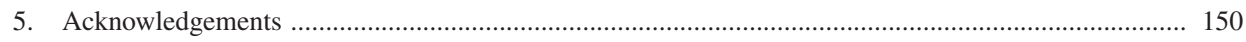

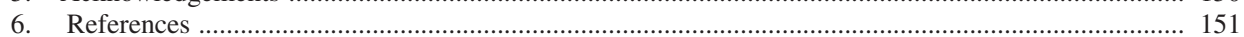




\begin{abstract}
Objective: Type 2 diabetes is associated with increased plasma concentrations of markers of coagulation and inflammation. Different studies show that treatment with HMG-CoA reductase inhibitors ('statins') is associated with anti-thrombotic and anti-inflammatory effects in addition to its cholesterol-lowering effect. Our objective was to evaluate the effect of pravastatin (40 $\mathrm{mg} /$ day) on markers of coagulation and inflammation in patients with type 2 diabetes.
\end{abstract}

Research design and methods: This was an open, randomized, cross over study, designed with an 8 week intervention period. The study group was comprised of 50 patients with type 2 diabetes (median $\mathrm{HbA} 1 \mathrm{c} 7.1 \%$ ) and serum total cholesterol of 5-10 mmol/l. We evaluated plasma levels of fibrinogen, F1+2, D-dimer, soluble tissue factor (sTF), von Willebrand Factor antigen (vWFag) and C-reactive protein (CRP) in blood samples drawn after fasting on day 1 and after 8 and 16 weeks.

Results: Significant reductions of total cholesterol (-22\%, p<0.001), LDL-cholesterol (-32\%, $\mathrm{p}<0.001)$ and triglycerides $(-10 \%, \mathrm{p}<0.05)$ were achieved after 8 weeks of treatment with pravastatin. In addition, significant reductions of plasma levels of F1+2 (-4.4\%, p<0.05), vWFag $(-5.3 \%, \mathrm{p}<0.05)$ and $\mathrm{sTF}(-3.4 \%, \mathrm{p}<0.05)$ were observed after treatment with pravastatin. Furthermore, plasma levels of CRP were also significantly reduced $(-13 \%, \mathrm{p}<0.05)$. Levels of fibrinogen and D-dimer did not decrease after treatment with pravastatin.

Conclusion: This study indicates that pravastatin reduces levels of markers of coagulation and inflammation in patients with type 2 diabetes. These anti-thrombotic and anti-inflammatory effects of treatment with statins could play a role in the reduction of cardiovascular complications in patients with type 2 diabetes. 


\section{Introduction}

Type 2 diabetes is a leading cause of vascular morbidity and death. It is often complicated by other cardiovascular risk factors such as hypercholesterolemia, hypertension, obesity and increased markers of coagulation ${ }^{1}$ and inflammation ${ }^{2}$. It has therefore been recommended that therapeutic prevention of cardiovascular disease in type 2 diabetes focus not only on optimal regulation of hyperglycemia but also on treatment of other cardiovascular risk factors ${ }^{3,4}$.

A subgroup analysis of several large randomized clinical trials ${ }^{5,6}$ shows that the relative risk for cardiovascular complications in type 2 diabetic patients can be reduced by $25 \%$ using aggressive treatment of dyslipidemia with hydroxymethylglutaryl-CoA reductase inhibitors, also known as statins. Treatment with statins may be beneficial not only because of these agents' lipid-lowering action, but also because of their effect on inflammation, endothelial function, adhesion of leucocytes to endothelium and thrombus formation ${ }^{7}$. Although statins have proven to be effective in the prevention of cardiovascular disease in type 2 diabetes, little is known about these socalled pleiotropic effects in patients with type 2 diabetes.

Our objective was to determine if treatment with pravastatin has potential anti-thrombotic and anti-inflammatory effects in patients with well-controlled type 2 diabetes. Therefore, we evaluated the effect of pravastatin on coagulation and inflammation markers in patients with type 2 diabetes and serum total cholesterol of 5-10 $\mathrm{mmol} / \mathrm{l}$.

\section{Research design and methods}

In this crossover trial 50 type 2 diabetic patients were studied to evaluate the effect of pravastatin on plasma coagulation and inflammation markers. A cross over design was chosen to allow treatment comparisons in one subject rather than between subjects and because the sample size needed for detection of treatment effects is smaller. Patients were recruited from the outpatient clinic of the Slotervaart Hospital (Amsterdam, The Netherlands). Men and women aged 18-80 years who were diagnosed with type 2 diabetes for at least one year and presented with serum cholesterol levels of 5.0-10.0 mmol/l were eligible for the study. Patients with acute medical conditions; surgery during the past 3 months; deep venous thrombosis or pulmonary embolism during the previous 3 months; significant renal, hepatic; metabolic or thyroid diseases; alcohol abuse or known familial hypercholesterolemia were excluded. Included patients were not concurrently receiving other lipid lowering, antithrombotic, or hormonal treatment, but were allowed to use an acetylsalicylic acid. Patients maintained their regular diet during the study period.

An open-label, randomized, cross over design was used. One half of the subjects (group A) began with pravastatin (Selektine, Bristol Myers Squibb, Woerden, The Netherlands, 40 mg/day), 
and the other half (group B) began with no treatment. Patients visited the outpatient clinic on day one, after the first period of 8 weeks, at which time pravastatin or no treatment was crossed over for another 8-week period, and after 16 weeks at the end of the study. At each visit blood samples were taken and patients' blood pressure was measured. The active treatment and its possible effects on the measured variables were presupposed to be washed out after 8 weeks. Laboratory outcomes at day 1 and at 8 and 16 weeks were compared, with each patient being his or her own control. All patients gave their informed consent, and the institutional Ethical Review Board of the Slotervaart Hospital, Amsterdam, approved the study.

\subsection{Blood sampling and laboratory methods}

Blood samples were obtained by standard venepuncture between 9:00 and 11:00 A.M. after a 12-h fast. Total, HDL, and LDL-cholesterol, triglycerides and fibrinogen were determined using standard laboratory procedures within $1 \mathrm{~h}$ after sampling. HDL cholesterol was determined using a direct assay. Safety parameters included creatinine, alanine amino transferase (ALT), aspartate amino transferase (AST), and creatine phosphokinase (CK) were measured with standard techniques. Glycemic control was monitored by evaluating fasting glucose, measured with standard techniques, and $\mathrm{HbA1c}$, determined by high performance liquid chromatography, as described elsewhere ${ }^{8}$. Levels of high-sensitivity $\mathrm{C}$ - reactive protein (hs-CRP) were determined with a near infrared particle immunoassay rate methodology (Beckman, Brea, CA). Analytical sensitivity, defined as the lowest measurable concentration that can be distinguished from zero with $95 \%$ confidence, is $0.2 \mathrm{mg} / \mathrm{ml}$. Measurements of prothrombin fragment F1+2 (Dade Behring, Marburg, Germany), the von Willebrand factor antigen (vWFag) (antibodies from Dako, Glostrup, Denmark), and soluble tissue factor (sTF) (American Diagnostica, Greenwich, $\mathrm{CT}$ ) were performed by enzyme-linked immunosorbent assay (ELISA). D-dimers were

Table 1. Patient characteristics.

\begin{tabular}{ll}
\hline & Type 2 diabetes patients $(\mathrm{n}=50)$ \\
\hline Age (years) & $59(54-64)$ \\
Sex ratio (M/F) & $25 / 25$ \\
Body mass index: BMI $\left(\mathrm{kg} / \mathrm{m}^{2}\right)$ & $28.9(26.8-33.1)$ \\
Diabetes duration (years) & $6.0(3.0-10.3)$ \\
HbA1c $(\%)$ & $6.9(6.4-7,7)$ \\
Insulin treatment, $\mathrm{n}$ & 31 \\
ACE-inhibitor, $\mathrm{n}$ & 11 \\
A2-antagonist, $\mathrm{n}$ & 5 \\
Acetyl-salicylic-acid, $\mathrm{n}$ & 13 \\
Current smokers, $\mathrm{n}$ & 12 \\
Plasma glucose $(\mathrm{mmol} / \mathrm{l})$ & $9.7(8.2-12.2)$ \\
Total cholesterol $(\mathrm{mmol} / \mathrm{l})$ & $6.3(5.7-6.9)$ \\
LDL cholesterol $(\mathrm{mmol} / \mathrm{l})$ & $4.1(3.6-4.6)$ \\
HDL cholesterol $(\mathrm{mmol} / \mathrm{l})$ & $1.2(1.0-1.5)$ \\
Triglycerides $(\mathrm{mmol} / \mathrm{l})$ & $1.7(1.4-2.8)$ \\
\hline
\end{tabular}

$\mathrm{n}$ indicates number of patients. Values are medians with 25 th -75 th percentile between brackets. 
measured with an automated quantitative latex particle immunoassay (BioMérieux, Durham, NC). Interleukin (IL)-12-p70, IL-1 $\beta$, IL-6, IL-10 and IL-8 were measured by cytometric bead array analysis (Beckton Dickinson Biosciences, San Diego, CA). Tumor necrosis factor-alpha (TNF-alpha) and IL-6 were measured with a high sensitivity ELISA (Quantikine HS human TNF-alpha and IL-6 ELISA; R\&D systems Europe, Abingdon, Oxon, U.K.).

\subsection{Statistics}

Results are presented as medians with 25 th and 75th percentiles. After testing for normality, Student's paired $t$ test or Wilcoxon's signed-rank test was used to compare values after a treatment or no-treatment period. The main outcome data were tested for carryover effect by comparing treatment effects between the two patients groups (group A vs. group B) ${ }^{9}$. No carryover effect was determined. Thus, we pooled data from patients after the treatment period, irrespective whether they started out or ended with the treatment period, and compared those with pooled data from the no-treatment period. Spearman's rank correlation coefficient analysis was used to examine associations between measured parameters. A two-tailed $\mathrm{P} \leq 0.05$ was considered to indicate statistical significance.

\section{Results}

A total of 56 patients were randomized to begin the study with an 8-week period of either pravastatin therapy or no treatment. Of those 56,50 patients completed the study; 4 patients stopped during the treatment period because of side effects attributed to the medication (skin and gastrointestinal complaints), 1 patient stopped during the treatment period because he had a myocardial infarction, and 1 patient stopped because lung carcinoma was detected.

Baseline clinical characteristics of the 50 patients are presented in Table 1 . The median age of the patients was 59 years. Patients were overweight, with a median BMI of $29 \mathrm{~kg} / \mathrm{m}^{2}$. Patients' diabetes was well controlled, with the median HbA1c being 7.1\%. In all, $62 \%$ of the patients were treated with insulin alone or in combination with oral antidiabetic agents, whereas the other $38 \%$ were treated with oral medication alone. In addition, $42 \%$ of the patients used medication for hypertension and $26 \%$ used acetyl-salicylic acid.

\subsection{Serum lipids and safety parameters}

The effects of therapy are shown in Table 2. Data are expressed as medians with 25 th and 75 th percentile. Statistically significant reductions of total cholesterol (-1.4 $\mathrm{mmol} / \mathrm{l}(-1.9$ to -1.0$))$, LDL cholesterol (-1.3 mmol/l (-1.74 to -0.95$))$ and triglycerides $(-0.19 \mathrm{mmol} / \mathrm{l}(-0.55$ to -0.08$))$ were achieved after treatment by pravastatin, indicating satisfactory compliance with the study medication. HDL levels did not change during drug treatment. Pravastatin did not influence glycemic control: HbA1c and glucose levels remained unchanged during treatment. Treatment with pravastatin did not significantly change safety parameters CK, ALT and AST. 


\subsection{Markers of coagulation and inflammation}

The effects of therapy on the principal study outcome markers are summarized in table 2. A statistically significant reduction in plasma levels of hs-CRP (-0.52 mg/dL (-1.34 to 0.27)) was achieved by pravastatin treatment. The prothrombin activation marker F1+2 was slightly, but significantly lower (-0.04 nmol/L (-0.2 to 0.04$))$ after active treatment. The selected markers of endothelial dysfunction, vWFag (-7\% (-12 to 3$)$ ) and sTF (-4 pg/ml (-45 to 4.5$)$ ) were also significantly reduced after pravastatin treatment. Despite the overall reduction in vWFag levels, the median concentration of vWFag was increased after treatment compared with before treatment (138\% (103 to 175$)$ vs. $131 \%$ (114 to 162)) because of the extreme nonnormal distribution (Figure 1).

Treatment did not significantly lower the levels of fibrinogen, D-dimer, IL-8 or TNF-alpha. In $20 \%$ of patients IL-12-p70, IL-1 $\beta$, IL-6 and IL-10 levels were detected with the cytometric bead array analysis. In this group of patients, no changes were measured after treatment with pravastatin (data not shown). We repeated the measurements of IL-6 using a high-sensitivity ELISA (R\&D systems Europe) with a detection limit $\approx 0.05 \mathrm{pg} / \mathrm{ml}$. IL-6 was still detectable only in $35 \%$ of patients. In the patients with detectable IL-6 levels, no changes were observed before and after pravastatin treatment $(2.9 \mathrm{pg} / \mathrm{ml}$ (1.8 to 3.2) vs. $2.6 \mathrm{pg} / \mathrm{ml}$ (1.9 to 4.5) $(\mathrm{P}=0.3)$.

To identify possible mechanisms for the decrease of CRP, F1+2, sTF and vWFag after pravastatin treatment, correlations with changes in other parameters were assessed. A statistically significant correlation was observed between change in F1+2 and degree of change of D-dimer $(\mathrm{r}=0.534 ; \mathrm{P}<0.0001)$, a finding that fits the notion that thrombin generation $(\mathrm{F} 1+2)$ is associated with fibrin formation and proteolytic cleavage (D-dimer). No correlation between change in F1+2 and changes in fibrinogen was observed. No correlations were found between

Table 2. Effect of pravastatin on lipids and coagulation and inflammation markers

\begin{tabular}{lllll}
\hline & No treatment & After pravastatin & p-value & $\begin{array}{l}\triangle \text { (after treatment }- \\
\text { after no-treatment })\end{array}$ \\
\hline Total cholesterol, mmol/l & $6.3(5.6,7.0)$ & $4.9(4.1,5.4)$ & $<0.001^{*}$ & $-1.4(-1.9,-1.0)$ \\
LDL cholesterol, mmol/l & $4.0(3.6,4.6)$ & $2.7(2.4,3.0)$ & $<0.001^{*}$ & $-1.3(-1.74,-0.95)$ \\
HDL cholesterol, mmol/l & $1.2(1.0,1.5)$ & $1.2(1.0,1.4)$ & $0.699 *$ & $0.03(-0.11,0.11)$ \\
Hs-CRP, mg/dl & $4.0(2.0,6.2)$ & $3.3(1.3,4.7)$ & $0.019 \dagger$ & $-0.52(-1.34,0.27)$ \\
TNF-alpha, pg/ml & $(2.6(2.1,3.8)$ & $2.7(2.2,3.9)$ & $0.967 \dagger$ & $+0.002(-0.98,1.5)$ \\
IL 8, pg/ml & $6.2(3.0,11.7)$ & $5.7(3.0,10.3)$ & $0.956 \dagger$ & $0(-2.7,3.9)$ \\
Fibrinogen, g/l & $3.2(2.9,3.9)$ & $3.3(2.8,3.8)$ & $0.231 \dagger$ & $0(-1.0,3.0)$ \\
D-dimer, $\mu \mathrm{g} / \mathrm{ml}$ & $0.26(0.19,0.39)$ & $0.27(0.19,0.45)$ & $0.104 \dagger$ & $-0.02(-0.09,0.05)$ \\
F1+2, nmol/l & $0.92(0.67,1.29)$ & $0.91(0.63,1.18)$ & $0.007 \dagger$ & $-0.04(-0.2,0.04)$ \\
vWFag, $\%$ & $131(114,162)$ & $138(103,175)$ & $0.027 \dagger$ & $-7(-12,3)$ \\
sTF, pg/ml & $119(87,158)$ & $104(64,146)$ & 0.044 & $-4(-45,4.5)$ \\
\hline
\end{tabular}

Data are expressed as medians with 25 th -75 th percentile.

*Normal distributed variable. $\dagger$ Not- normal distributed variable. 
Figure 1. The reduction of $\mathrm{vWFag}$ was $-5.3 \%$ after pravastatin treatment (dotted line) in spite of increased median concentration of vWFag (NT: $131 \%(114,162)$ vs. PRAV: $138 \%(103,175))$ which is possible due to the extreme nonnormal distribution of vWFag. NT: after 8 weeks no- treatment; PRAV: after 8 weeks pravastatin treatment.

\section{Von Willebrand Factor Antigen}

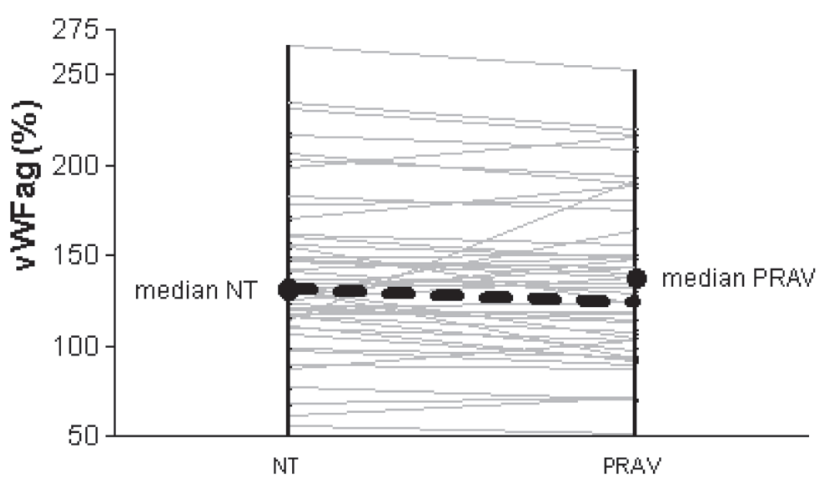

reductions of hs-CRP, F1+2, sTF and vWFag and changes in total, LDL or HDL cholesterol or triglycerides. A weak correlation was observed between degree of change of vWFag and the change of hs-CRP ( $r=0.312 ; \mathrm{P}=0.031)$. No other correlations were found between the observed reductions in hs-CRP, F1+2, sTF and vWFag.

\section{Discussion}

Statins comprise a group of agents that are increasingly prescribed to counteract atherosclerosis and related cardiovascular complications. Statins also show marked clinical efficacy in individuals with type 2 diabetes. Several lines of evidence suggest that the beneficial effects of statins are attributable not only to their lipid-lowering action, but also the 'pleiotropic' actions of statins.

Current knowledge of such pleiotropic effects is largely derived from in vitro experiments and studies in patients with hypercholesterolemia. To specifically determine the effects of pravastatin on inflammation, coagulation, and endothelial activation markers in type 2 diabetic patients, we performed the present study. Our data demonstrated that 2 months of treatment with pravastatin reduced the levels of CRP, F1+2, sTF, and vWFag. These biological alterations may have clinical significance, as type 2 diabetes is associated with increased inflammation and coagulation activity and impaired endothelial function.

CRP is a marker of inflammation; its plasma concentration levels correlate with the severity and extent of the atherosclerotic process in the arterial wall and is consistently associated with prognosis in ischemic heart disease. Several studies have shown that treatment with statins lowers CRP ${ }^{10-12}$ in hypercholesterolemic individuals and that patients with higher levels of CRP have greater benefit from treatment with statins than patients with lower concentrations ${ }^{13}$. In our study population of type 2 diabetic patients, we observed a significant reduction in plasma levels 
of CRP after treatment with pravastatin. This observation confirms previous observations ${ }^{14,15}$ and suggests that statins have anti-inflammatory properties in type 2 diabetic patients also.

The anticoagulant potential of pravastatin was assessed by measuring two relevant markers, F1+2 and D-dimer. The F1+2 peptide fragment is released when prothrombin is converted into thrombin, with concentrations of F1+2 in plasma reflecting the amount of in vivo generated thrombin. Several studies have shown that statins reduce circulating levels of F1+2 ${ }^{16,17}$ and F1+2 in samples from bleeding time wounds in patients with hypercholesterolemia ${ }^{18,19}$. Aoki et al. ${ }^{20}$ showed that increased platelet-dependent thrombin generation in hypercholesterolemic patients normalizes after pravastatin treatment, whereas Szczeklik et al. ${ }^{18}$ found that simvastatin inhibits thrombin formation in bleeding time blood. Aspirin had no further effect on thrombin formation. Likewise, Dangas et al. ${ }^{19}$ showed that pravastatin reduced ex vivo thrombus formation, whereas the reduction was attenuated in patients on aspirin. The reduction in thrombin or thrombus formation in these studies may have been secondary to an antiplatelet effect of statins ${ }^{21}$. Our study extends the above findings to patients with type 2 diabetes, in whom we observed that pravastatin lowered levels of $\mathrm{F} 1+2$. A possible explanation for this reduction of in vivo thrombin formation in these diabetic patients with mild hypercholesterolemia is that like in the previous described studies with hypercholesterolemic patients, platelet-mediated thrombin formation is reduced by statin treatment. In contrast, aspirin did not diminish thrombin production in these patients. The mechanism by which statins might influence platelet-mediated thrombin production remains unknown. In contrast to $\mathrm{F} 1+2$, we observed no significant reduction of the level of D-dimer after pravastatin treatment. On the basis of our study we were not able to unravel the pathophysiological mechanism behind this observation.

Theoretically, a lowered cellular STF production or exposure may also be responsible for reduced thrombin production. At this stage, it remains uncertain whether a reduced level of sTF, as observed in our study, may translate into lower thrombin production, because the role of sTF as a stimulus of coagulation has not been established. The small decrease in sTF should probably be interpreted as diminished proteolytic cleavage from injured endothelial cells, which would support the concept of stabilization of endothelial cell function by statins ${ }^{22}$.

The level of circulating vWFag is another marker that is considered to reflect endothelial injury. VWF is a glycoprotein stored in endothelial cells and secreted into the circulation. It increases in parallel with the degree of endothelial cell damage. In our patients the basal levels of vWFag were quite high (median 131\%), a finding that might reflect the longer-term vascular perturbation inflicted by type 2 diabetes (median duration of type 2 diabetes in these patients was 6 years). The observed decrease of vWFag during treatment, confirming observations on statins in patients with hypercholesterolemia ${ }^{17 ; 23 ; 24}$, could be explained by an endothelial improving-effect of pravastatin. Data on endothelial cell-improving effects of statins in type 2 diabetic patients are scarce and conflicting. Endothelial cell-mediated vasoreactivity improves in 
diabetic rats after treatment with pravastatin or cerivastatin ${ }^{25,26}$. In a study with diabetic patients, vasoreactivity improved as soon as after 3 days of treatment with cerivastatin. In addition, the plasma level of soluble vascular adhesion molecule-1, a plasma marker for endothelial dysfunction, was decreased in these patients after 3 months of treatment ${ }^{14}$. However, another study reported the absence of any effect on nitric oxide-dependent vasoreactivity in type 2 diabetic patients after 4 weeks of aggressive lipid-lowering treatment with atorvastatin ${ }^{27}$. To our knowledge, our study is the first to show that pravastatin reduces levels of vWFag and sTF in diabetes patients.

Fibrinogen has been claimed as an independent cardiovascular risk factor, and increased levels of fibrinogen have been observed in patients with various atherosclerotic diseases. One study in patients with poorly controlled diabetes showed a decrease of fibrinogen after treatment with pravastatin $^{28}$. In the present study no change of fibrinogen was found after two months treatment. This finding is in line with the majority of studies in hypercholesterolemic patients, where no reduction in fibrinogen levels after statin treatment has been observed.

Some of the effects of pravastatin on thrombin formation and endothelial function may be induced by an anti-inflammatory action of this class of agents. Statins are able to block the synthesis of important isoprenoid intermediates, which serve as lipid attachments for a variety of intracellular signaling molecules. To identify a mechanism for the observed changes in inflammation, coagulation, and endothelial function after pravastatin treatment, correlations with reduction of lipids were assessed. The fact that no significant correlation was found between reductions in CRP, F1+2, vWFag and sTF and the reduction of lipids, supports the concept that effects other than lipid-lowering action play a role in these changes. In addition, the change of vWFag after pravastatin treatment was associated with the degree of change of CRP, suggesting that the endothelial cell-improving effect was attributable to an anti-inflammatory and not a cholesterol-lowering effect of pravastatin. We speculated that the regulation of vWFag and sTF were related, both being markers of endothelial cell dysfunction. However, we did not find an association between changes of both parameters. This might be explained by a different pattern of cleavage, secretion or elimination from the circulation.

In conclusion, our data demonstrate that treatment with pravastatin for 2 months induces antiinflammatory, anti-thrombotic and endothelial-improving actions in patients with type 2 diabetes and mild hypercholesterolemia. These findings provide an additional biological basis for the presumed importance of pleiotropic effects of statin treatment in patients with type 2 diabetes and cardiovascular disease. 


\section{Acknowledgements}

We thank M de Rijk and OA Ternede, research nurses from the Slotervaart Hospital for their great help in this investigation. We thank the personnel of the Diagnostic Laboratory of Vascular Medicine (AMC), APA Groot from the Laboratory for Experimental Internal Medicine (AMC) and $\mathrm{H}$ Bout from the Laboratory of Clinical Chemistry, Slotervaart Hospital for their excellent technical assistance. We thank GJ Weverling from the department of Clinical Epidemiology (AMC) for statistical advice.

H Ten Cate is a Clinical Established Investigator of the Netherlands Heart Foundation. The study costs were defrayed from the material budget provided by the Netherlands Heart Foundation to DW Sommeijer and H Ten Cate. Bristol Myers Squib provided an unrestricted study grant. 


\section{References}

1. Frohlich J., Steiner G. Dyslipidaemia and coagulation defects of insulin resistance. Int J Clin Pract Suppl 2000; 14-22.

2. Stehouwer C.D., Gall M.A., Twisk J.W., Knudsen E., Emeis J.J., Parving H.H. Increased urinary albumin excretion, endothelial dysfunction, and chronic low-grade inflammation in type 2 diabetes: progressive, interrelated, and independently associated with risk of death. Diabetes 2000; 51:11571165 .

3. Grundy S.M., Pasternak R., Greenland P., Smith S.Jr., Fuster V. AHA/ACC scientific statement: Assessment of cardiovascular risk by use of multiple-risk-factor assessment equations: a statement for healthcare professionals from the American Heart Association and the American College of Cardiology. J Am Coll Cardiol 1999; 34:1348-1359.

4. O'Keefe J.H.Jr., Miles J.M., Harris W.H., Moe R.M., McCallister B.D. Improving the adverse cardiovascular prognosis of type 2 diabetes. Mayo Clin Proc 1999; 74:171-180.

5. Pyorala K., Pedersen T.R., Kjekshus J., Faergeman O., Olsson A.G., Thorgeirsson G. Cholesterol lowering with simvastatin improves prognosis of diabetic patients with coronary heart disease. A subgroup analysis of the Scandinavian Simvastatin Survival Study (4S). Diabetes Care 1997; 20:614620.

6. Goldberg R.B., Mellies M.J., Sacks F.M., Moyé L.A., Howard B.V., Howard W.J., Davis B.R., Cole T.G., Pfeffer M.A., Braunwald E. Cardiovascular events and their reduction with pravastatin in diabetic and glucose-intolerant myocardial infarction survivors with average cholesterol levels: subgroup analyses in the cholesterol and recurrent events (CARE) trial. The Care Investigators. Circulation 1998; 98:2513-2519.

7. Palinski W. New evidence for beneficial effects of statins unrelated to lipid lowering. Arterioscler Thromb Vasc Biol 2001; 21:3-5.

8. Eckerbom S., Bergqvist Y., Jeppsson J.O. Improved method for analysis of glycated haemoglobin by ion exchange chromatography. Ann Clin Biochem 1994; 31:355-360.

9. Altman D.G. Practical statistics for medical research, 1991.

10. Ridker P.M., Rifai N., Pfeffer M.A., Sacks F., Braunwald E. Long-term effects of pravastatin on plasma concentration of C-reactive protein. The Cholesterol and Recurrent Events (CARE) Investigators. Circulation 1999; 100:230-235.

11. Ridker P.M. Inflammatory biomarkers, statins, and the risk of stroke: cracking a clinical conundrum. Circulation 2002; 105:2583-2585.

12. Albert M.A., Danielson E., Rifai N., Ridker P.M. Effect of statin therapy on C-reactive protein levels: the pravastatin inflammation/CRP evaluation (PRINCE): a randomized trial and cohort study. Jama 2001; 286:64-70.

13. Ridker P.M., Rifai N., Pfeffer M.A., Sacks F.M., Moye L.A., Goldman S., Flaker G.C., Braunwald E. Inflammation, pravastatin, and the risk of coronary events after myocardial infarction in patients with average cholesterol levels. Cholesterol and Recurrent Events (CARE) Investigators. Circulation 1998; 98:839-844.

14. Tsunekawa T., Hayashi T., Kano H., Sumi D., Matsui-Hirai H., Thakur N.K., Egashira K., Iguchi A. Cerivastatin, a hydroxymethylglutaryl coenzyme a reductase inhibitor, improves endothelial function in elderly diabetic patients within 3 days. Circulation 2001; 104:376-379.

15. van de Ree M.A., Huisman M.V., Princen H.M., Meinders A.E., Kluft C. Strong decrease of high sensitivity C-reactive protein with high-dose atorvastatin in patients with type 2 diabetes mellitus. Atherosclerosis 2003; 166:129-135.

16. Cipollone F., Mezzetti A., Porreca E., Di Febbo C., Nutini M., Fazia M., Falco A., Cuccurullo F., Davì G. Association between enhanced soluble CD40L and prothrombotic state in hypercholesterolemia: effects of statin therapy. Circulation 2002; 106:399-402.

17. Joukhadar C., Klein N., Prinz M., Schrolnberger C., Vukovich T., Wolzt M., Schmetterer L., Dorner 
G.T. Similar effects of atorvastatin, simvastatin and pravastatin on thrombogenic and inflammatory parameters in patients with hypercholesterolemia. Thromb Haemost 2001; 85:47-51.

18. Szczeklik A., Musial J., Undas A., Gajewski P., Góra P., Swad ba J., Jankowski M. Inhibition of thrombin generation by simvastatin and lack of additive effects of aspirin in patients with marked hypercholesterolemia. J Am Coll Cardiol 1999; 33:1286-1293.

19. Dangas G., Badimon J.J., Smith D.A., Unger A.H., Levine D., Shao J.H., Meraj P., Fier C., Fallon J.T., Ambrose J.A. Pravastatin therapy in hyperlipidemia: effects on thrombus formation and the systemic hemostatic profile. J Am Coll Cardiol 1999; 33:1294-1304.

20. Aoki I., Aoki N., Kawano K., Shimoyama K., Maki A., Homori M., Yanagisawa A., Yamamoto M., Kawai Y., Ishikawa K. Platelet-dependent thrombin generation in patients with hyperlipidemia. J Am Coll Cardiol 1997; 30:91-96.

21. Kearney D., Fitzgerald D. The anti-thrombotic effects of statins. J Am Coll Cardiol 1999; 33:13051307.

22. Koyama T., Ohdama S., Aoki N. Plasma tissue factor reflects endothelial cell injury rather than upregulation of tissue factor expression. Thromb Haemost 1997; 78:972.

23. Bickel C., Rupprecht H.J., Blankenberg S., Espinola-Klein C., Rippin G., Hafner G., Lotz J., Prellwitz W., Meyer J. AtheroGene Group.Influence of HMG-CoA reductase inhibitors on markers of coagulation, systemic inflammation and soluble cell adhesion. Int J Cardiol 2002; 82:25-31.

24. Kario K., Matsuo T., Hoshide S., Kobayashi H., Sakata T., Mizuno O., Mitsuhashi T., Ikeda U., Miyata T., Shimada K. Lipid-lowering therapy corrects endothelial cell dysfunction in a short time but does not affect hypercoagulable state even after long-term use in hyperlipidemic patients. Blood Coagul Fibrinolysis 1999; 10:269-276.

25. Kobayashi T., Matsumoto T., Kamata K. Mechanisms underlying the chronic pravastatin treatmentinduced improvement in the impaired endothelium-dependent aortic relaxation seen in streptozotocininduced diabetic rats. Br J Pharmacol 2000; 131:231-238.

26. Dumont A.S., Hyndman M.E., Dumont R.J., Fedak P.M., Kassell N.F., Sutherland G.R., Verma S. Improvement of endothelial function in insulin-resistant carotid arteries treated with pravastatin. J Neurosurg 2001; 95:466-471.

27. van Venrooij F.V., van de Ree M.A., Bots M.L., Stolk R.P., Huisman M.V., Banga J.D. Aggressive lipid lowering does not improve endothelial function in type 2 diabetes: the Diabetes Atorvastatin Lipid Intervention (DALI) Study: a randomized, double-blind, placebo-controlled trial. Diabetes Care 2002; 25:1211-1216.

28. Miossec P., Zkhiri F., Paries J., David-Dufilho M., Devynck M.A., Valensi P.E. Effect of pravastatin on erythrocyte rheological and biochemical properties in poorly controlled Type 2 diabetic patients. Diabet Med 1999; 16:424-430. 


\section{CHAPTER}

\section{General discussion}

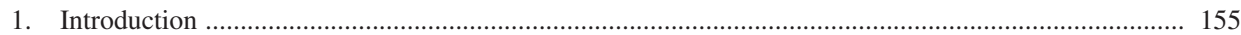

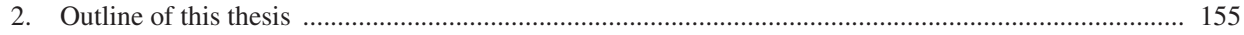

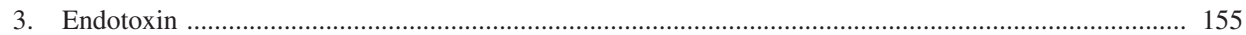

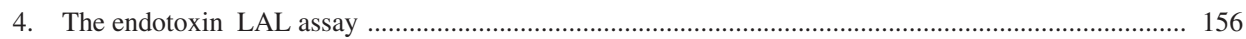

4.1 Introduction of the international endotoxin standard ............................................................ 156

4.2 Sensitive assay to determine levels endotoxin ..................................................................... 157

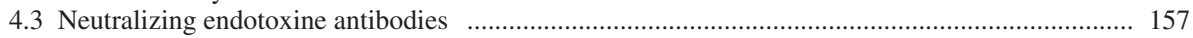

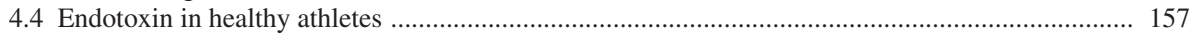

4.5 PCT sensitive marker for bacterial infections .................................................................. 159

5. Endotoxin and procalcitonine assays in inflammatory disease ...................................................... 159

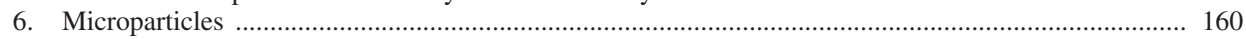

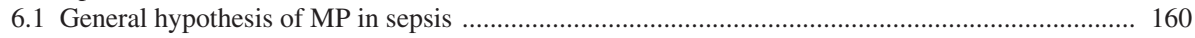

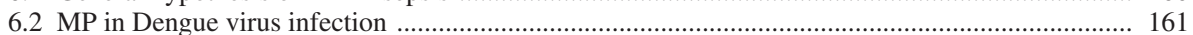

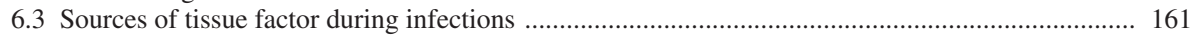

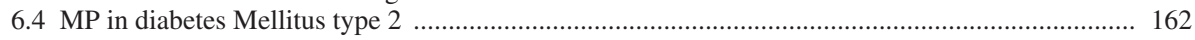

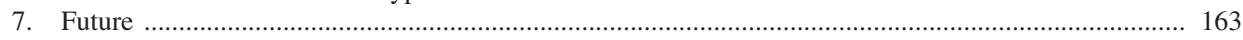

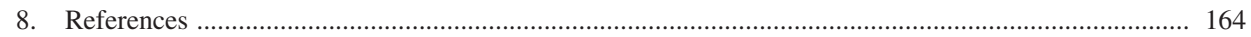


$+\infty$ 


\section{Introduction}

Bacterial infection and particularly sepsis is associated with major complications like multiple organ failure, contributing to a persistent high mortality rate. In the management of patients with suspicion of gram negative sepsis, a major problem remains to be the timely diagnosis. Bacterial cultures require too much time and although novel PCR based techniques may help to establish an earlier identification of specific micro-organisms, rapid diagnosis remains a real challenge. In addition, patients with sepsis and other diseases associated with systemic activation of the immune system show signs of activated blood coagulation. This activated coagulation also involves the generation of microparticles (MP) that have become the subject of increasing interest because of their presumed involvement in the pathophysiology of inflammation and coagulation crosstalk. Hence, an impact of MP in processes like sepsis related multi organ failure and thrombosis has been proposed. Thus, the quantification of MP and identification of their cellular source become of diagnostic interest in the management of diverse patient populations.

\section{Outline of this thesis}

The work presented in this thesis deals with both aspects of the pathophysiology of inflammation. First, the bacterial component endotoxin and its consequences in vivo; second, the generation of MP as part of the host response to inflammation.

Having outlined the general features of endotoxin and its analysis in chapter 1, we describe the applications of endotoxin testing in relation to outcomes in different settings. It should be noted that the development of the endotoxin assay in plasma as well as other fluids like cerebrospinal fluid, has been the subject of previous studies by the defendant in collaboration with other investigators ${ }^{1}$. The previous studies provide the basis for the application and validation of endotoxin assays in practice and the results of a number of such studies are included in this thesis.

\section{Endotoxin}

The general idea underlying endotoxin measurement in biological material is that it confirms or rules out the presence of significant numbers of gram negative bacteria and for this purpose endotoxin assay by LAL test is a widely applied screening test. One relevant and widely used application is the screening of any biologically used products for endotoxin contamination. The second potential use of the endotoxin test is the determination of significant endotoxin concentrations in blood (plasma) as an indication of infection (clinical) or as a research tool, $e g$ in studies where specific inflammatory stimuli are being investigated such as the intake of a high fat meal ${ }^{2}$. Several technical issues are important in this regard and have been the topic of 
much discussion in the past decades. As outlined in chapter I endotoxins are bound to different molecules upon entry of the bloodstream. Compounds like BPI (Bactericidal Permeability Increasing Protein), LBP (LPS (endotoxin) Binding Protein) and different lipoproteins all bind and modify the biologic activity of endotoxin in blood. Furthermore, neutralizing antibodies are generated and these act as important modifiers of endotoxin activity as well. Different methods have been and are being applied to optimize sensitivity and to maintain specificity for particular endotoxins. Without having to discuss all technical issues related to the quality of the assays, the aspect of analytical sensitivity is relevant to address shortly.

\section{The endotoxin LAL assay}

Independent of methodology all LAL assays are standardized using samples in water. Therefore, unless the sample is water some components of the solution may interfere with the LAL test such that the recovery of endotoxin is affected. The LAL assay is dependent on the proper activation of the cascade of serine protease that makes up the lysate. In a gel clot assay, the final step of the cascade involves the cleavage of the clotting protein, coagulogen, and its polymerization into a solid gel. The last step in a chromogenic assay is the cleavage of a chromogenic substrate and the resulting release of the chromophore pNA. Without the proper concentration of divalent cations, the enzymes in the lysate cannot function properly and this will not yield a readable signal. At extreme $\mathrm{pH}$ gel formation may be impaired; on the other hand highly basic solutions may cause non-enzymatic chromogenic substrate cleavage, suggesting more contamination than is actually present. In order to overcome LAL interference, heating ${ }^{4}$, dilution $^{4}$, and chloroform extraction of serum/plasma were all found to be efficient in removing inhibition. Besides the interfering constituents in blood (plasma) an inhibitory effect of the anticoagulant in which the blood was collected, was noted. The same experiments suggested that higher levels of endotoxin were found in platelet rich plasma compared with platelet poor plasma ${ }^{5}$.

\subsection{Introduction of the international endotoxin standard}

To further optimize the LAL assay the international standard was introduced and endotoxin levels expressed in endotoxin units (EU). This standardization makes it possible to compare LAL assay data from different laboratories, which was previously debated because of the difference in potencies of the standard endotoxin used to prepare the calibration curve. The EU is defined by the reference standard endotoxin EC-5 (Escherichia coli-5). Furthermore, LAL from different manufacturers and/or different lot numbers of LAL may have different potencies with the same standard of endotoxin. Therefore standard and lysate together are responsible for the EU of standards calibrated against the reference standard (EC-5). 


\subsection{Sensitive assay to determine levels endotoxin}

The concentration of endotoxin measured with the gel-clot test has a detection range of 0.03-0.5 $\mathrm{EU} / \mathrm{ml}$ in water and the turbidimetric assay is sensitive down to $0.001 \mathrm{EU} / \mathrm{ml}^{3}$. In comparison, with the chromogenic assay in blood in which the neutralizing capacity of blood elements is circumvented by heating the platelet rich plasma to $75^{\circ} \mathrm{C}$, we could accomplish a detection limit of $0.0036 \mathrm{EU} / \mathrm{ml}^{4}$. A highly sensitive test may be relevant for excluding the presence of endotoxin in blood and indeed during the past decade a whole blood assay for endotoxin has been successfully applied to exclude gram-negative infection in patients admitted to the intensive care ${ }^{6}$. For this indication, the endotoxin activity assay has been approved by the $\mathrm{FDA}^{7,8}$. However, this particular assay was less suited for predicting subsequent morbidity, since there were no major differences in organ failure among those patients with a low, intermediate or high endotoxin level in this activity assay ${ }^{9}$. Thus, with the FDA approved endotoxin test low endotoxin levels fairly good rule out gram negative infection, but the host response to inflammation is less well predicted. The latter limitation does not seem odd given the array of host response molecules not directly associated with endotoxin that are involved in inflammation.

\subsection{Neutralizing endotoxine antibodies}

Our studies involving the endotoxin assay confirm that the LAL based assay does not contribute much to the diagnosis of gram-negative infections. In cases of localized infections such as in the cattle study (chapter II) no systemic endotoxin activity was detected which may for a large part be explained by the presence of neutralizing antibodies. An argument supporting the importance of such antibodies is the observation that post-operative patients developing SIRS had lower serum Ig endotoxin antibodies levels than those who did not ${ }^{12}$. In the study of Braun et al. decreased plasma endotoxin core antibodies in patients undergoing cardiac surgery are reported and the concentrations of these antibodies were significantly lower in patients developing MODS and were also predictors of long-term mortality ${ }^{10-11,13}$. Alternatively, there is little dissemination from localized infections to the systemic circulation, explaining low endotoxin levels in blood of these cows.

Essentially, a similar question was tackled in the chapter on endurance performance.

\subsection{Endotoxin in healthy athletes}

The initial hypothesis was that the gut barrier function for bacterial endotoxins and potentially for fungal beta glucans would be disturbed during severe prolonged exercise and would be a contributor to gastro-intestinal (GI) complaints ${ }^{10}$.

As stated, the ironman distance triathlon in Embrun in France is one of the most challenging long distance triathlons, hence we assumed that this would be an 'ideal' trigger of inflammation. Although in $74 \%$ of the athletes a low level of endotoxemia was observed in the hours after 
exercise, there was no correlation between systemic endotoxemia and GI complaints. In contrast, there was a clear cytokine response immediately after exercise and an acute phase response the day after exercise and both positive correlated with severe GI complaints. This study supports the leakage of endotoxin to the systemic blood compartment due to increased gut permeability and/or translocation of a.o. gram negative bacteria. The fact that there was no correlation with systemic complaints after endurance training does not rule out a causal relation, which may be masked due to the fact that most inflammatory reactions are due to secondary messengers rather than direct endotoxin effects. The latter fits with the observation that cytokine releases as well as acute phase reactions were linked to systemic complaints. It should be noted that the transfer of endotoxin into the circulation might be an ongoing event also under physiological conditions. A number of papers have reported the presence of low levels of LPS in apparently normal individuals ${ }^{14-18}$. Relative mild challenges such as the intake of a fat meal or smoking and minimal invasive procedures like colonoscopy may indeed raise the systemic level of endotoxin in blood. The reason for this phenomenon may be the relatively large amounts of endotoxin present in the gut (estimated as about 1 gram of LPS derived from 100 trillion commensal microorganisms), allowing for a trivial fraction of LPS to pass into the blood circulation occasionally.

Under provoked conditions such as exercise and fatty meal intake, the fraction that passes to the blood may also be temporarily increased due to increased barrier permeability of the gut.

It is known from previous studies that the prolonged severe exercise challenge in men is associated with ischemia of parts of the intestines that promote direct passage of bacteria and/or endotoxin to blood. The recent fatty meal study shows that even without gross intestinal disruption translocation of endotoxin occurs. A similar mechanism has been experimentally observed in hyperphagic leptin-deficient ob/ob mice as well as in hyperleptinemic $\mathrm{db} / \mathrm{db}$ mice ${ }^{19}$. In addition, apo E -/- mice also had increased endotoxin levels in portal blood after a fatty meal as compared to normal mice ${ }^{20}$. Based on these observations the transfer (or translocation, or leakage) of endotoxin into the portal blood may be a relatively common phenomenon and the clearance function of the liver and other reticular endothelial compartments as well as the presence of neutralizing antibodies will then determine the persistence of endotoxin in blood.

The clinical relevance of these physiological perturbations may be quite substantial. Prolonged exposure to endotoxin and the generated inflammatory mediators may be a contributor to atherosclerosis. The relation with such long term diseases may be postulated on the basis of prolonged and repeated challenges with endotoxin from the gut after fatty meals or in conditions such as chronic infection during periodontitis ${ }^{21}$. These pathophysiological connections merit more thorough experimental and clinical studies. 


\subsection{PCT sensitive marker for bacterial infections}

In addition, a new marker, procalcitonin (PCT), was measured. PCT levels appeared to be more sensitive and specific than C-reactive protein (CRP) and interleukin 6 (IL-6) in the differentiation between bacterial infection and other inflammatory processes. The PCT levels before exercise were low and increased 4-fold after exercise, however they did not correlate with endotoxin or creatine kinase (as indicator of muscle damage) levels. Nevertheless, PCT levels correlated with the acute phase reaction indicated by CRP and IL-6 rises in blood. Hence, it appeared that PCT measurements did not give an early indication of inflammation, but were probably induced by exercise induced cytokine release.

\section{Endotoxin and procalcitonin assays in inflammatory disease}

To determine whether in a setting of community acquired infection the endotoxin assay would be helpful in predicting outcomes we performed the study described in chapters VI. Here, we also tested a rapid bedside test for endotoxin in comparison with the traditional LAL assay (chapter V). The two assays did not match well in detecting endotoxin levels, moreover neither test predicted a complicated course in patients with a community-acquired infection. We found that in patients that were clinically stable on admission the main factors associated with fatal outcome were high age and co-morbidity, while endotoxin, cytokines (IL-6, TNF-alpha, IL-10) and PCT levels were not sufficiently predictive. Recent data suggest that the prognostic value of PCT testing may be improved by serial measurements in combination with determination of lactate. The rising trend of both lactate and PCT, especially between day 1 and 2, had superior prognostic value for 28 day mortality compared with absolute levels ${ }^{22}$. PCT is also investigated in the context of other inflammatory diseases. An example is the observation of high levels of PCT in patients with critical illness in heatstroke and the further validation of this biomarker may be of interest ${ }^{23}$.

Nevertheless, in our study (chapter V) in patients that were in shock upon admission the endotoxin assay was the best predictor of fatal outcome. In summary, in clinical practice, endotoxin testing in patients suspected from infection is only warranted to exclude a poor outcome in those already hospitalized at the intensive care department. In patients already in shock, the endotoxin assay may predict a poor outcome. In practice, it is our impression that the endotoxin assays are not widely used for either purpose, because of the limited specificity coupled to many technical problems in performing such tests at the bedside or at a rapid laboratory basis. However, in clinical medicine the endotoxin assay is not the only laboratory test that performs poorly. In patients with inflammatory diseases such as sepsis, there is no single test that predicts outcomes sufficiently well to guide management decisions.

The choice of antibiotics for instance remains based primarily on detection of the microorganism, either by culture or nowadays increasingly by PCR based methods that safe time, rather than on indirect markers such as endotoxin, CRP or PCT. 


\section{Microparticles}

During sepsis DIC is supposed to be one of the main contributors to multi organ failure. This association between an activated coagulation system and a systemic inflammatory state led to a number of experimental studies of the underlying mechanisms, involving coagulation and fibrinolysis in relation to inflammation and its mediators. One of the elements that drew attention of clinical researchers was the microparticle (MP) fraction released upon activation of intravascular cells. Indeed, over the past years the interest in MP has substantially increased. The first studied MP was from platelets and early studies showed that these platelet derived MP were highly procoagulant. In addition, it became clear that all vascular cells could contribute to the circulating MP fraction, although platelets are the abundant fraction in plasma from normal individuals ${ }^{24}$ as well as plasma from patients with diverse conditions. Since sepsis is a microvascular disorder involving large vascular beds it could be expected that MP would be a potentially relevant contributor to procoagulant activity in blood. One of the postulated mechanisms was that monocytes that induced tissue factor at their surface during endotoxemia ${ }^{25}$ would also provide tissue factor enriched MP as a trigger of DIC. Indeed this was confirmed by the study of meningococcal sepsis in which thrombin generation in plasma was initiated by microparticles in a factor VII/tissue factor dependent way ${ }^{26}$. We studied platelet, granulocyte, erythrocyte and endothelial MP and their tissue factor expression in 9 patients with sepsis and multiple organ failure. This analysis provided some surprising data. First, in contrast to the expectation that MP would be increased in concentration during sepsis, the numbers of particles were reduced compared to healthy controls and differed in their cellular origin. Second, thrombin generation triggered by MP from the plasma of these patients occurred only partially in a factor VII/tissue factor dependent way. In fact in 8/9 of these patients thrombin was generated in a factor XI dependent way and in 2 patients there was evidence of factor XII mediated thrombin generation. The blood from 2 patients in whom the contribution of factor XII was largest (based on the strongest inhibition of thrombin generation by anti-factor XII antibodies) contained both the largest number of granulocyte derived MP and the highest elastase concentration. In this regard it is of interest that recent studies provide a novel role for the contact activation system. In particular factor XII appears to be involved in collagen stimulated platelet dependent thrombin generation in vitro ${ }^{27,28}$ and this may be the mechanism by which factor XII contributes to arterial thrombus formation and stability ${ }^{29}$. The liberation of MP carrying factor XII would point to a mechanism by which contact activation indeed supports thrombin generation and potentially arterial thrombosis.

\subsection{General hypothesis of MP in sepsis}

The difference between thrombin formation in meningococcal sepsis by a factor VII/tissue factor dependent way and in postoperative sepsis by a factor XII dependent way, merits further investigation. 
In general, the interpretation of MP fractions in plasma should be regarded with caution. It was quite surprising to note that the concentration of MP was lower in patients with sepsis than in normals. However, if we assume that MP are actively involved in processes like thrombosis one would indeed expect that MP's with greatest coagulation potency are being scavenged in ongoing thrombotic processes. The studies from the Furie group have in detail revealed that MPs'contribute to thrombus formation in experimental models ${ }^{30-32}$. The tissue factor bearing MP are probably a major source of 'blood borne' tissue factor activity ${ }^{33,34}$ and the finding of low or absent tissue factor bearing MP in plasma cannot be seen as an indication of the absence of such particles in blood. In fact, the opposite may be the case, where MP carrying factor XII antigen may not be active participants in thrombosis, however this remains highly speculative. In addition, MP of any cellular origin are captured in atherosclerotic plaques ${ }^{33}$, thus MP that still circulate reflect merely the process of MP formation.

\subsection{MP in Dengue virus infection}

To further investigate the involvement of MP in a systemic inflammatory condition we studied MP during severe Dengue virus infection. Severe Dengue virus infection is characterized by a haemorrhagic tendency and thrombocytopenia. Assuming MP as active participants in the pathophysiology of haemostasis and thrombosis it was anticipated that both MP concentrations and characteristics would be altered as compared to normal individuals. In our study 2 patients suffered from uncomplicated dengue fever (DF), 4 patients suffered from the potentially life-threatening dengue haemorrhagic fever (DHF) and 2 patients suffered from dengue shock syndrome (DSS). All of these patients had a significant decrease in absolute number of circulating MP, with a striking deficiency in platelet-derived MP. The latter may be explained by a lack of circulating platelets due to impaired bone marrow production, although the scavenging of platelet MP in leaky vessels (to prevent bleeding) may also be a relevant protective mechanism. In this study we did not detect an association between MP and severity of disease. We observed a rise in absolute numbers of MP originating from other cell populations like endothelial cells, monocytes, $\mathrm{T}_{\mathrm{H}}$-cells and $\mathrm{T}_{\mathrm{s}}$-cells, and a relatively large percentage of MP exposing tissue factor. Patterns of MP and associated tissue factor should also be regarded with caution, since the cellular association not necessarily reflects the source of tissue factor. This issue has since many years been a topic of controversy in the case of tissue factor on neutrophils $\mathrm{s}^{36-38}$. However, studies now indicate that blood cells and their MP may not only be involved in production of molecules such as tissue factor but are also able to scavenge (or absorb) molecules perhaps as a means of transportation ${ }^{36}$.

\subsection{Sources of tissue factor during infections}

The primary source of cellular tissue factor is uncertain in most diseases. Endothelial cells probably do not express tissue factor in vivo. Platelets are able to generate tissue factor as demonstrated in recent studies ${ }^{39}$. Monocytic tissue factor may be transferred to activate platelets. In plasma from healthy subjects tissue factor-like activity, identified via partial inactivation by anti-tissue factor antibodies, is found. In addition to MP-bound tissue factor, plasma tissue 
factor also comprises the alternatively spliced, truncated human tissue factor, but its function, if any, remains to be established. Both truncated and full-length tissue factor are present in experimental thrombi, hence a function of truncated tissue factor may be postulated. Since the truncated form of tissue factor does not have procoagulant activity it may in fact inhibit full length tissue factor and act as a natural anticoagulant ${ }^{40,41}$.

As a hypothetical mechanism we postulate that during infections monocytes/macrophages provide the primary source of tissue factor. When monocytes/macrophages shed MP with tissue factor activity, they may transfer this tissue factor to activated platelets. To further transfer tissue factor to endothelial cells by platelets and/or MP shed from platelets the presence of P-selectin glycoprotein ligand-1 (PSGL-1) on activated platelets and endothelial cells, also known as CD62P, plays a critical role. P-selectin is an adhesion molecule which interacts between platelets and endothelial cells. Platelet P-selectin also acts in concert with PSGL-1 in monocytic synthesis of tissue factor. Tissue factor gene expression is transiently induced in human adherent monocytes, reaching maximal tissue factor protein levels between days 3 and $5^{42-44}$. This may explain the time path we observed in Dengue virus infection where there was a trend for enhanced tissue factor exposure on monocytic particles at day 2 and on endothelial derived particles at day 3. Secondly, a near deficiency in absolute numbers of platelet-derived microparticles may have been caused by the interaction between activated vascular endothelial cells and platelet derived MP.

We have not addressed the thrombin generating capacity of Dengue virus associated MP yet and we therefore are uncertain whether the circulating MP fraction has pro-hemostatic activity, which might potentially control bleeding in patients with Dengue hemorrhagic fever. The observation that infusion of either desmopressin or recombinant activated Factor VIIa in patients with a bleeding tendency increases MP number and procoagulant activity ${ }^{45,46}$ is suggestive of a contributing effect of MP induced by these prohemostatic agents in patients suffering from severe Dengue virus infection ${ }^{48-50}$.

\subsection{MP in diabetes Mellitus type 2}

In the last chapter we explore some characteristics of MP in a cross-over study in diabetes mellitus type 2 (DM2) patients treated with statins. Several studies indicate that enhanced platelet activation is a relevant phenomenon in patients with DM2 and the degree of platelet activation (measured as tromboxane B2 in serum) is correlated with degree of glycemic control $(\mathrm{HbA} 1 \mathrm{c})^{47}$. Whether platelet activity is also associated with clinical disease such as degree of atherosclerosis and cardiovascular outcomes is uncertain. With regard to therapy, inhibition of platelets with aspirin is only indicated in patients with additional cardiovascular risk factors and not as primary prevention. 
An increased level of circulating MP has been suggested to be one of the procoagulant determinants in patients with DM2 and high levels of MP have been observed in such patients. Statins are a group of cholesterol lowering drugs with potential pleiotropic effects including modulation of inflammatory and procoagulant activity ${ }^{49} \mathrm{~A}$ number of studies have shown that statin treatment has an influence on platelet activation ${ }^{50,51}$ and platelet membrane composition $^{52,53}$. In our study pravastatin clearly reduced cholesterol levels, however the total number of MP and MP expressing tissue factor was not different after 8 weeks of treatment. Pravastatin did however affect the platelet membrane composition suggested by a reduction of GPIIb/IIIa density on platelet-derived microparticles. GPIIb/IIIa, known as the fibrinogen receptor on platelets, is released from the platelet's storage pool and transported to the cell membrane upon platelet activation ${ }^{54}$. Interestingly, there was no significant correlation between cholesterol levels and GPIIb/IIIa density of the MP suggesting that processes other than lipid metabolism are involved in MP formation in patients with DM2. The functional implications of attenuation of GPIIb/IIIa receptors may be of some importance, since in patients with DM2, the parentally used GPIIb/IIIa inhibitors have been shown to be more effective in reducing coronary occlusion after percutaneous coronary interventions than in patients without diabetes ${ }^{55,56}$.

\section{Future}

Taken together it appears from experimental studies that MP are contributing factors to thrombosis due to their procoagulant activity, mainly characterized by expression of tissue factor, but also in part by other proteins such as factor XII. MP may be critical messengers among cells and be involved in cell-cell communication by exchanging specific proteins like tissue factor and P-selectin. The membrane composition, as eg indicated by density of specific receptors like GPIIb/IIIa, may contribute to specific features of the prothrombotic nature of MP.

In addition to participating in thrombosis, MP may be regulators of hemostasis and the finding of lowered MP in hemorrhagic disorders like dengue hemorrhagic fever suggests a pro-hemostatic function. That way MP may be both helpful (hemostasis) and detrimental thrombosis players in the delicate hemostatic balance in health as well as disease.

From a diagnostic point of view it should be noted that the detectable fraction of MP in blood may not be the pathophysiologically relevant fraction in situations where MP are thought to be absorbed in (thrombosis) or on atherosclerotic lesions. Recent studies point to a potentially clinically relevant diagnostic application, ie in malignancies. Here, elevated MP in blood has been detected in cancers, and in some cases the number has been associated with the severity of disease. However, both their diagnostic utility and pathophysiological relevance in cancer and thrombosis remains to be determined. 


\section{References}

1 Thomas L.L., ten Cate H., Sturk A., Joop K., ten Cate J.W. Quantitative chromogenic endotoxin determination in cerebrospinal fluid. Clin Chim Acta 1983; 127(1):137-9.

2 Erridge C., Attina T., Spickett C.M., Webb D.J. A high-fat meal induces low-grade endotoxemia: evidence of a novel mechanism of postprandial inflammation. Am J Clin Nutr. 2007; 86(5):1286-92

3 Novitsky T.J., Roslansky P.F. Quantification of endotoxin inhibition in serum and plasma using a turbidimetric LAL assay. Prog Clin Biol Res 1985; 189:181-96.

4 Sturk A., Joop K., ten Cate J.W., Thomas L.L. Optimalization of a chromogenic assay for endotoxin in blood. Prog Clin Biol Res 1985; 189: 117-37.

5 Sturk A., Janssen M.E., Muylaert F.R., Joop K., Thomas L.L., ten Cate J.W. Endotoxin testing in blood. Prog Clin Biol Res 1987; 231:371-85.

6 van Deventer S.J., Buller H.R., ten Cate J.W., Sturk A., Pauw W. Endotoxemia: an early predictor of septicaemia in febrile patients. Lancet 1988; 1(8586):605-9.

7 Marshall J.C., Walker P.M., Foster D.M., Harris D., Ribeiro M., Paice J., Romaschin A.D., Derzko A.N. Measurement of endotoxin activity in critically ill patients using whole blood neutrophil dependent chemiluminescence. Crit Care 2002; 6:342-348.

8 Marshall J.C., Foster D., Vincent J.L., Cook D.J., Cohen J., Dellinger R.P., Opal S., Abraham E., Brett S.J., Smith T., Mehta S., Derzko A., Romaschin A. MEDIC study. Diagnostic and prognostic implications of endotoxinemia in criticall illness: Results of the MEDIC study. J Infect Dis 2004; 190:527-534.

9 Meisner M. Biomarkers of sepsis: clinically useful? Curr Opin Crit Care. 2005; 11(5):473-80.

10 Braun J.P., Buhner S., Kastrup M., Dietz E., Langer K., Dohmen P.M., Lochs H., Spies C. Barrier function of the gut and multiple organ dysfunctions after cardiac surgery. J Int Med Res 2007; 35(1):72-83.

11 Moretti E.W., Newman M.F., Muhlbaier L.H., Whellan D., Petersen R.P., Rossignol D., McCants C.B. Jr., Phillips-Bute B., Bennett-Guerrero E. Effects of decreased preoperative endotoxin core antibody levels on long-term mortality after coronary artery bypass graft surgery. Arch Surg 2006; 141(7):637-41.

12 Stephens R.C., Fidler K., Wilson P., Barclay G.R., Mythen M.G., Dixon G.L., Turner M.W., Klein N.J., Peters M.J. Endotoxin immunity and the development of the systemic inflammatory response syndrome in critically ill children. Intensive Care Med 2006; 32(2):286-94.

13 Strutz F., Heller G., Krasemann K., Krone B., Müller G.A.Relationship of antibodies to endotoxin core to mortality in medical patients with sepsis syndrome. Intensive Care Med 1999; 25(5):435-44.

14 Wiedermann C.J., Kiechl S., Dunzendorfer S., Schratzberger P., Egger G., Oberhollenzer F., Willeit J. Association of endotoxemia with carotid atherosclerosis and cardiovascular disease: prospective results from the Bruneck Study. J Am Coll Cardiol 1999; 34:1975-81.

15 Goto T., Eden S., Nordenstam G., Sundh V., Svanborg-Edin C., Matfsby-Baltzer I. Endotoxin levels in sera of elderly individuals. Clin Diagnost Lab Immunol 1994; 1:684-8

16 Hasday J.D., Bascom R., Costa J.J., Fitzgerald T., Dubin W. Bacterial endotoxin is an active component of cigarette smoke. Chest 1999; 115:829-35.

17 Bolke E., Jehle P.M., Storck M., Nothnagel B., Stanescu A., Orth K. Endotoxin release and endotoxin neutralizing capacity during colonoscopy. Clin Chim Acta 2001; 303:49-53.

18 Niebauer J., Volk H.D., Kemp M., Dominguez M., Schumann R.R., Rauchhaus M., Poole-Wilson P.A., Coats A.J., Anker S.D. Endotoxin and immune activation in chronic heart failure: a prospective cohort study. Lancet 1999; 353:1838-42.

19 Brun P., Castagliuolo I., Di Leo V., Buda A., Pinzani M., Palù G., Martines D. Increased intestinal permeability in obese mice: new evidence in the pathogenesis of nonalcoholic steatohepatitis. Am J Physiol Gastrointest Liver Physiol 2007; 292:G518-25.

20 Yoshimatsu M., Terasaki Y., Sakashita N., Kiyota E., Sato H., van der Laan L.J., Takeya M. Induction of macrophage scavenger receptor MARCO in nonalcoholic steatohepatitis indicates possible involvement of endotoxin in its pathogenic process. J Exp Pathol 2004; 85:335-43.

21 Hettne K.M., Weeber M., Laine M.L., ten Cate H., Boyer S., Kors J.A., Loos B.G. Automatic mining of

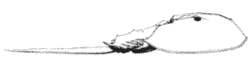


the literature to generate new hypotheses for the possible link between periodontitis and atherosclerosis: lipopolysaccharide as a case study. J Clin Periodontol 2007; 34(12):1016-24.

22 Phua J., Koay E.S., Lee K.H. Lactate, procalcitonin, and amino-terminal pro-B-type natriuretic peptide versus cytokine measurements and clinical severity scores for prognostication in septic shock. Shock 2008; 29(3):328-33.

23 Hausfater P., Hurtado M., Pease S., Juillien G., Lvovschi V.E., Salehabadi S., Lidove O., Wolff M., Bernard M., Chollet-Martin S., Riou B. Is procalcitonin a marker of critical illness in heatstroke? Intensive Care Med 2008; Epub ahead of print.

24 Berckmans R.J., Nieuwland R., Böing A.N., Romijn F.P., Hack C.E., Sturk A. Cell-derived microparticles circulate in healthy humans and support low grade thrombin generation. Thromb Haemost 2001; 85(4):639-46.

25 Franco R.F., de Jonge E., Dekkers P.E., Timmerman J.J., Spek C.A., van Deventer S.J., van Deursen P., van Kerkhoff L., van Gemen B., ten Cate H., van der Poll T., Reitsma P.H. The in vivo kinetics of tissue factor messenger RNA expression during human endotoxemia: relationship with activation of coagulation. Blood 2000; 96(2):554-9.

26 Nieuwland R., Berckmans R.J., McGregor S., Böing A.N., Romijn F.P., Westendorp R.G., Hack C.E., Sturk A. Cellular origin and procoagulant properties of microparticles in meningococcal sepsis. Blood 2000; 95(3):930-5.

27 Heemskerk J.W., Vuist W.M., Feijge M.A., Reutelingsperger C.P., Lindhout T. Collagen but not fibrinogen surfaces induce bleb formation, exposure of phosphatidylserine, and procoagulant activity of adherent platelets: evidence for regulation by protein tyrosine kinase-dependent $\mathrm{Ca} 2+$ responses. Blood 1997; 90(7):2615-25.

28 Heemskerk J.W., Feijge M.A., Henneman L., Rosing J., Hemker H.C. The Ca2+-mobilizing potency of alpha-thrombin and thrombin-receptor-activating peptide on human platelets - concentration and time effects of thrombin-induced Ca2+ signaling. Eur J Biochem 1997; 249(2):547-55.

29 Gailani D., Renné T. Intrinsic pathway of coagulation and arterial thrombosis. Arterioscler Thromb Vasc Biol 2007; 27(12):2507-13.

30 Furie B., Furie B.C. Thrombus formation in vivo. J Clin Invest. 2005; 115(12):3355-62.

31 Gross P.L., Furie B.C., Merrill-Skoloff G., Chou J., Furie B. Leukocyte-versus microparticle-mediated tissue factor transfer during arteriolar thrombus development. J Leukoc Biol 2005; 78(6):1318-26.

32 Sim D., Flaumenhaft R., Furie B., Furie B. Interactions of platelets, blood-borne tissue factor, and fibrin during arteriolar thrombus formation in vivo. Microcirculation 2005; 12(3):301-11.

33 Giesen P.L., Rauch U., Bohrmann B., Kling D., Roqué M., Fallon J.T., Badimon J.J., Himber J., Riederer M.A., Nemerson Y. Blood-borne tissue factor: another view of thrombosis. Proc Natl Acad Sci U S A. 1999; 96(5):2311-5.

34 Sim D., Flaumenhaft R., Furie B., Furie B.C. Interactions of platelets, blood-borne tissue factor, and fibrin during arteriolar thrombus formation in vivo. Microcirculation 2005; 12(3):301-11.

35 Leroyer A.S., Isobe H., Lesèche G., Castier Y., Wassef M., Mallat Z., Binder B.R., Tedgui A., Boulanger C.M.J. Cellular origins and thrombogenic activity of microparticles isolated from human atherosclerotic plaques. Am Coll Cardiol 2007; 49(7):772-7.

36 Egorina E.M., Sovershaev M.A., Olsen J.O., Osterud B. Granulocytes do not express but acquire monocytederived tissue factor in whole blood: evidence for a direct transfer. Blood 2008; 111(3):1208-16

37 Breimo E.S., Østerud B. Generation of tissue factor-rich microparticles in an ex vivo whole blood model. Blood Coagul Fibrinolysis 2005; 16(6):399-405.

38 Egorina E.M., Sovershaev M.A., Bjørkøy G., Gruber F.X., Olsen J.O., Parhami-Seren B., Mann K.G., Østerud B. Intracellular and surface distribution of monocyte tissue factor: application to intersubject variability. Arterioscler Thromb Vasc Biol 2005; 25(7):1493-8.

39 Panes O., Matus V., Sáez C.G., Quiroga T., Pereira J., Mezzano D. Human platelets synthesize and express functional tissue factor. Blood 2007; 109(12):5242-50.

40 Szotowski B., Antoniak S., Rauch U. Alternatively spliced tissue factor: a previously unknown piece in the puzzle of hemostasis. Trends Cardiovasc Med 2006; 16(5):177-82. 
41 Proulle V., Hugel B., Guillet B., Trichet C., Rafowicz A., Lambert T., Freyssinet J.M., Dreyfus M. Injection of recombinant activated factor VII can induce transient increase in circulating procoagulant microparticles. Thromb Haemost 2004; 91(5):873-8.

42 Hall A.J., Vos H.L., Bertina R.M. Lipopolysaccharide induction of tissue factor in THP-1 cells involves Jun protein phosphorylation and nuclear factor kappaB nuclear translocation. J Biol Chem 1999; 274(1):376-83.

43 van den Eijnden M.M., Steenhauer S.I., Reitsma P.H., Bertina R.M. Tissue factor expression during monocyte-macrophage differentiation. Thromb Haemost 1997; 77(6):1129-36.

44 Østerud B., Bjørklid E. Sources of tissue factor. Semin Thromb Hemost 2006; 32(1):11-23.

45 van Zoelen M.A., Bakhtiari K., Dessing M.C., van’t Veer C., Spek C.A., Tanck M., Meijers J.C., van der Poll T. Ethyl pyruvate exerts combined anti-inflammatory and anticoagulant effects on human monocytic cells. Thromb Haemost 2006; 96(6):789-93.

46 Horstman L.L., Valle-Riestra B.J., Jy W., Wang F., Mao W., Ahn Y.S. Desmopressin (DDAVP) acts on platelets to generate platelet microparticles and enhanced procoagulant activity. Thromb Res 1995; 79(2):163-74.

47 Undas A., Brozek J., Jankowski M., Siudak Z., Szczeklik A., Jakubowski H. Plasma homocysteine affects fibrin clot permeability and resistance to lysis in human subjects. Arterioscler Thromb Vasc Biol 2006; 26(6):1397-404.

48 Pea L., Roda L., Moll F. Desmopressin treatment for a case of dengue hemorrhagic fever/dengue shock syndrome. Clin Infect Dis 2001; 33(9):1611-2.

49 Chuansumrit A., Tangnararatchakit K., Lektakul Y., Pongthanapisith V., Nimjaroenniyom N., Thanarattanakorn P., Wongchanchailert M., Komwilaisak P. The use of recombinant activated factor VII for controlling life-threatening bleeding in Dengue Shock Syndrome. Blood Coagul Fibrinolysis 2004; 15(4):335-42.

50 Chuansumrit A., Wangruangsatid S., Lektrakul Y., Chua M.N., Zeta Capeding M.R., Bech O.M. Dengue Study Group. Control of bleeding in children with Dengue hemorrhagic fever using recombinant activated factor VII: a randomized, double-blind, placebo-controlled study. Blood Coagul Fibrinolysis 2005; 16(8):549-55.

51 Sommeijer D.W., Joop K., Leyte A., Reitsma P.H., ten Cate H. Pravastatin reduces fibrinogen receptor gpIIIa on platelet-derived microparticles in patients with type 2 diabetes. J Thromb Haemost 2005; 3(6):1168-71.

52 van de Ree M.A., Huisman M.V., Princen H.M., Meinders A.E., Kluft C. DALI-Study Group. Strong decrease of high sensitivity C-reactive protein with high-dose atorvastatin in patients with type 2 diabetes mellitus. Atherosclerosis 2003; 166(1):129-35.

53 Cipollone F., Mezzetti A., Porreca E., Di Febbo C., Nutini M., Fazia M., Falco A., Cuccurullo F., Davì G. Association between enhanced soluble CD40L and prothrombotic state in hypercholesterolemia: effects of statin therapy. Circulation 2002; 106(4):399-402.

54 Joukhadar C., Klein N., Prinz M., Schrolnberger C., Vukovich T., Wolzt M., Schmetterer L., Dorner G.T. Similar effects of atorvastatin, simvastatin and pravastatin on thrombogenic and inflammatory parameters in patients with hypercholesterolemia. Thromb Haemost 2001; 85(1):47-51.

55 Szczeklik A., Musiał J., Undas A., Gajewski P., Góra P., Swad ba J., Jankowski M. Inhibition of thrombin generation by simvastatin and lack of additive effects of aspirin in patients with marked hypercholesterolemia. J Am Coll Cardiol 1999; 33:1286-1293.

56 Ridker P.M., Rifai N., Pfeffer M.A., Sacks F.M., Moye L.A., Goldman S., Flaker G.C., Braunwald E. Inflammation, pravastatin, and the risk of coronary events after myocardial infarction in patients with average cholesterol levels. Cholesterol and Recurrent Events (CARE) Investigators. Circulation 1998; 98(9):839-44.

57 Atwater B.D., Roe M.T., Mahaffey K.W. Platelet glycoprotein IIb/IIIa receptor antagonists in non-ST segment elevation acute coronary syndromes: a review and guide to patient selection. Drugs 2005; 65(3):313-24.

58 Maree A., Fitzgerald D.J. Glycoprotein IIb/IIIa antagonists in acute coronary syndromes: where are we now? Semin Vasc Med. 2003; 3(4):385-90. 
Summary 

Inflammation, either bacterial or nonbacterial, coagulation and the determinants of their interplay are longstanding topics of research. The present thesis describes the application of laboratory diagnostic and research tools in various disease states and models relating to this interplay, as discussed in Chapter 1.

\section{Chapter II: Eelationship between intra-uterine bacterial contamination, endotoxin levels} and the development of endometritis in postpartum cows with dystocia or retained placenta

This study investigated the relationship between intra-uterine bacterial contamination, endotoxin levels and the development of endometritis in cows that experienced a dystocia or retained their placenta. From a total of 59 cows plasma and uterine lochia samples were collected to determine lipopolysaccharide (LPS) and the plasma IgG anti-LPS concentrations. Of these cows, 15 were healthy, 31 suffered from retained placenta (RP) and 13 had dystocia, All were clinically examined 1 or 2 days after parturition. RP cows had significantly higher LPS levels in uterine lochia as compared to cows with dystocia and healthy postpartum cows. High LPS levels in lochia at 1 or 2 days postpartum were significantly related to abnormal cervical discharge. Nevertheless, LPS was not detectable in blood in any group, also no significant difference was measured in anti-LPS IgG levels in plasma. We concluded that the presence of E. coli and LPS (endotoxins) in lochia early postpartum favors the development of uterine infections by A. pyogenes and gram-negative anaerobes later postpartum. LPS was not observed in plasma, suggesting that either it is not absorbed into the blood, or IgG anti-LPS or other detoxification mechanisms efficiently detoxify them.

Chapter III: Relationship between gastro-intestinal complaints and endotoxemia, cytokine release and the acute-phase reaction during and after a long-distance triathlon in highly trained men

This study was performed to establish whether the gastro-intestinal (GI) complaints observed during and after ultra-endurance exercise are related to gut ischaemia-associated leakage of endotoxins into the circulation and subsequent cytokine production. We collected blood samples from 29 athletes before, immediately after, and at 1,2 and 16 hours after a longdistance triathlon. Most participants (93\%) had gastro-intestinal symptoms, and even $7 \%$ of the participants abandoned the race because of severe gastro-intestinal distress. Endotoxin levels were detectable in $68 \%$ of the athletes, associated with a reduction in IgG anti-LPS antibody levels. We observed immediately after the race an increased plasma level of IL-6 reflective of an acute phase response, associated with an increase in CRP and a decrease in pre-albumin concentrations. Nevertheless, we could not establish any significant correlation between the extent of endotoxemia and the gastro-intestinal symptoms. Although LPS does enter the circulation after ultra-endurance exercise, LPS leakage does not seem to be responsible for the observed gastro-intestinal problems in these athletes. 


\section{Chapter IV: Plasma procalcitonin before and after ultra endurance exercise}

To investigate whether levels of plasma procalcitonin are indicative for bacterial translocation and are not elevated by muscle damage, we have determined plasma levels of procalcitonin, endotoxin and creatininekinase before and after ultra endurance exercise. There was (mild) endotoxemia and significant muscle damage detectable in some, but not all (29), athletes, even before and at 1,2 and 16 hours after the exercise. Plasma procalcitonin concentrations before exercise were low, and increased after the exercise. Plasma procalcitonin concentrations did not significantly correlate with endotoxin levels or with increasing plasma concentrations of creatinekinase (muscle damage). Nevertheless, the maximum procalcitonin concentrations correlate with maximum IL-6 levels and with the acute phase reactant CRP. We concluded that during and after ultra endurance exercise the rise in procalcitonin is likely to be induced by exercise-induced cytokine alterations.

\section{Chapter V: Predictive values for fatal outcome in septic patients: A comparison between the SIMPLY RED ${ }^{\circledR}$ - and the chromogenic LPS-assays}

The presence of LPS in the systemic circulation is an important predictor of for fatal outcome. The detection of LPS by the regular chromogenic Limulus amoebocyte lysate (LAL) assay is too expensive and labour intensive to perform on only a few patient samples per day. A simple bedside test applied on a whole blood sample, the SimpliRED ${ }^{\circledR}$ Endotoxin (SRE) assay, has been reported to be of clinical value in critically ill patients. In the present study we evaluated the LAL and SRE assays for their ability to predict mortality in patients clinically suspected to have sepsis.

74 Patients were included; out of 61 septic patients 6 died as result of sepsis, while in 13 patients sepsis could not be confirmed by bacterial culture. Of the 55 survivors, samples of 5 were positive for the LAL, 12 for the SRE and 2 for both assays. Both the positive and negative predictive values were low for both assays in all septic patients. Even when considering APACHE II score selected patients the positive and negative predicted value remained too low for clinical use. The performance of the blood and local cultures were similar to the results of the both endotoxin assays. We conclude that neither the SRE nor the LAL assay is useful in predicting or excluding mortality in patients clinically suspected of having sepsis.

\section{Chapter VI: Endotoxin, cytokines and procalcitonin in febrile patients admitted to hospital: identification of subjects with high mortality risk}

We prospectively examined 464 febrile patients (median age, 61 years) for predictors of inhospital death. We measured clinical data (age, underlying disease, duration of fever, chills, and shock on admission) and plasma endotoxin, TNF-alpha, IL-6, IL-10, and procalcitonin 
levels. The mortality rate was higher in patients with shock on admission ( $\mathrm{n}=31 ; 7$ nonsurvivors) compared to patients not in shock at admission ( $n=433 ; 26$ nonsurvivors). The endotoxin concentration showed the strongest association with mortality risk, predicting 5 of the 7 deaths with a $5 \%$ false-positive rate. For patients without shock on admission, mortality was associated with age and underlying disease: clinical data predicted $30 \%$ of the deaths, whereas IL-6 and procalcitonin levels identified an extra $10 \%$.

When febrile patients are screened on hospital admission to identify those with a high risk for mortality, clinical judgment (age, underlying disease, and recent history) outweighs the predictive value of endotoxin, cytokine, and procalcitonin levels. Only in patients who present with shock measurement of endotoxin levels may help to predict a fatal outcome.

\section{Chapter VII: Microparticles from patients with Multiple Organ Dysfunction Syndrome and} Sepsis support coagulation through multiple mechanisms

We investigated the number and cellular origin of MP in patients with multiple organ dysfunction syndrome (MODS) and sepsis. 9 Patients and 14 healthy controls were included. Number and cellular origin of the MP were determined with flow-cytometry. The coagulation activation status in vivo was quantified by plasma prothrombin fragment F1+2- and thrombinantithrombin (TAT) measurements.

Annexin V-positive MP in the patients originated predominantly from platelets (PMP), and to a lesser extent from erythrocytes, endothelial cells (EMP) and granulocytes (GMP).

Compared to healthy controls, the numbers of annexin V-positive PMP and TF-exposing MP were decreased, EMP were decreased or found equal, erythrocyte-derived MP were equal and GMP were increased. GMP numbers correlated with plasma concentrations of elastase, but not with CRP or IL-6 concentrations. Patient MP triggered thrombin formation, which was reduced compared to the healthy controls and strongly inhibited by an anti-factor XII MoAb $(n=2)$, by anti-factor XI MoAb $(n=8)$ or by anti-TF MoAb $(n=4)$. Concentrations of F1+2 and TAT were elevated and correlated inversely proportional with the number of circulating MP and their thrombin generation capacity.

Chapter VIII: Decreased number of microparticles in severe dengue virus infection possible involment in disease pathogenesis.

Severe dengue virus infections are characterized by haemorrhagic manifestations that are thought to be due to a combination of thrombocytopenia and thrombocytopathia. Recent data suggest that abnormalities in blood coagulation and fibrinolysis also play a role in disease severity. In view of the evidence for a role of MP in coagulation, we investigated the presence 
and cellular source of circulating MP in patients suffering from a severe dengue virus infection. This study demonstrated a near deficiency of MP (especially platelet derived MP) during a severe infection.

Chapter IX: Pravastatin reduces levels of the glycoprotein III a subunit from the fibrinogen receptor on platelet derived microparticles in patients with type 2 diabetes

A major clinical problem in patients with diabetes is the high risk for cardiovascular diseases. Different studies show that statins (HMG-CoA reductase inhibitors) reduce cardiovascular complications in patients with diabetes. This anti-thrombotic effect is primarily ascribed to its cholesterol lowering effect, however other so called pleiotropic effects have also be proposed. The objective in this study was to study the effect of pravastatin, in patients with diabetes (type 2), on the number, cellular origin and antigenic composition of MP.

Patients ( $\mathrm{n}=48)$ with type 2 diabetes were treated for 8 weeks in a cross over study with pravastatin or no medication. The number of MP was determined as annexin $\mathrm{V}$ positive signal determined with flow-cytometry, and the antigen composition of the MP with mean fluorescence. We found that the number, cellular origin and the tissue factor exposure on MP was unaffected by pravastatin. Nevertheless there was a reduction, during Pravastatin treatment, of Glycoprotein IIIa (CD61) on platelet MP. Reduced expression of the fibrinogen receptor and may be responsible in part for the risk reduction of cardiovascular event by statin treatment. 
Samenvatting 
$+\infty$ 
In dit proefschrift wordt een aantal aspecten beschreven welke samenhangen met de reactie van het lichaam op ontsteking. Twee aspecten spelen een hoofdrol in het proefschrift: ten eerste, de meting in lichaamsvloeistoffen van bacterieel endotoxine (lipopolysaccharide, LPS), als belangrijke mediator van bacteriële infectie in mens en dier. Ten tweede, de reactie van de bloedstolling op ontsteking en hiermee gepaard gaande ziektebeelden. Specifiek werd onderzoek gedaan naar het vrijkomen in bloed van micropartikels (MP) en dan met name naar de cellulaire afkomst en relevantie van deze MP. In hoofdstuk 1 wordt de achtergrond van dit onderzoek geschetst en wordt ingegaan op de opbouw van het proefschrift, omvattende twee verschillende onderdelen.

Hoofdstuk II: Relatie tussen bacteriële baarmoeder ontsteking, endotoxine concentraties en het ontwikkelen van baarmoederslijmvliesontsteking in runderen na een moeilijke bevalling of bij het achterblijven van de placenta.

Deze studie bestudeert de relatie tussen bacteriële baarmoederontsteking en endotoxine concentraties enerzijds, en het ontwikkelen van baarmoederslijmvliesontsteking nadat de koe een moeilijke bevalling heeft gehad of wanneer de placenta achterblijft anderzijds. Van de 59 runderen werden plasma en baarmoeder slijmmonsters verzameld, waarin de endotoxine concentraties werden bepaald. In het plasma werd ook de IgG anti-endotoxine concentratie gemeten.

Van deze 59 runderen waren 15 gezond met een normale bevalling, 31 waarbij de placenta was achtergebleven ('retained placenta', RP) en 13 hadden dystocia. Alle runderen werden klinisch onderzocht 1 of 2 dagen na baring. De Runderen met RP hadden beduidend hogere niveaus LPS in het baarmoederslijm vergeleken met dystocia en gezonde postpartum koeien. De hoge niveaus LPS in baarmoederslijm bij 1 of 2 dagen post partum hadden een duidelijke relatie met betrekking tot abnormale cervicale vloeiing. Desalniettemin, was er geen LPS aantoonbaar in het plasma van deze drie groepen runderen, ook werden geen significante verschillen gemeten in niveaus van anti-LPS IgG in plasma. Concluderend uit deze studie, zou de aanwezigheid van E. coli en LPS (endotoxinen) in baarmoederslijm postpartum een aanwijzing kunnen zijn voor het ontwikkelen van bacteriële baarmoederontsteking post partum. Het niet aantoonbaar zijn van LPS in plasma zou verklaard kunnen worden, doordat LPS niet de baarmoederwand kan passeren, of doordat anti-LPS antistoffen het LPS efficiënt binden en klaren.

\section{Hoofdstuk III: Verband tussen gastro-intestinale klachten en endotoxemia, cytokinen en de acuut-fase reactie tijdens en na een triatlon, bij zeer getrainde atleten.}

Deze studie werd uitgevoerd om vast te stellen of de gastro-intestinale (GI) klachten die tijdens en na zeer extreme inspanningen worden waargenomen in relatie kon worden gebracht met darm ischemie geassocieerde lekkage van endotoxine in de circulatie met bijbehorende cytokine 
productie. Bij 29 atleten werd bloed afgenomen voor de triatlon, onmiddellijk daarna, en 1, 2 en 16 uur na de triatlon. De meeste deelnemers (93\%) hadden gastro-intestinale symptomen, en $7 \%$ van de deelnemers verlieten de race wegens gastro-intestinale problemen. Endotoxines waren aantoonbaar in $68 \%$ van de atleten, in relatie met verlaagde anti IgG anti-LPS concentraties in het bloed. Ook werd onmiddellijk na de race een verhoogde acuut fasereactie waargenomen met een duidelijk verhoogde IL-6 concentratie, gepaard gaande met een verhoogd CRP en een daling van de pre-albumine concentraties. Er werd geen significante correlatie aangetoond tussen endotoxemia en de gastro-intestinale klachten. Hoewel bekend is dat LPS vanuit de darmen naar de systemische circulatie kan passeren gedurende extreme inspanningen, kon er geen verband worden aangetoond tussen de gastro-intestinale klachten en het aangetoonde LPS in het bloed.

\section{Hoofdstuk IV: Plasma procalcitonine concentratie voor en na extreme inspanning}

Om te onderzoeken of verhoogde concentraties procalcitonine in plasma van atleten indicatief zijn voor bacteriële translocatie en verklaard worden door spierschade, zijn plasmaconcentraties van procalcitonine, endotoxine en creatininekinase voor en na extreme inspanning bepaald. Er waren (milde) endotoxemie en significante spierschade aantoonbaar in de meeste, maar niet alle atleten (29), vóór en na, 1, 2 en 16 uren van inspanning. Concentraties van het plasma procalcitonine vóór waren laag, en stegen na de inspanning. Concentraties van het plasma procalcitonine correleerden niet met endotoxine concentraties of met stijgende plasmaconcentraties van creatinekinase (maat voor spierschade). Wel correleerden de maximale procalcitonine concentraties met maximale IL-6 concentraties en met de acuut fase reactant CRP. Concluderend, tijdens en na extreme inspanning stijgt de procalcitonine concentratie in bloed, hetgeen waarschijnlijk samenhangt met proinflammatoire cytokine productie en niet door lekkage van endotoxines.

\section{Hoofdstuk V: Voorspellende waarden voor septische patiënten met hoge mortaliteit: Een vergelijking tussen de SIMPLY RED ${ }^{\circledR}$ en de LAL LPS-bepaling.}

De aanwezigheid van LPS in de circulatie is een belangrijke voorspeller van een slechte prognose bij patiënten. De bepaling van LPS door de chromogene amoebocyte Limulus lysate (LAL) analyse is duur en arbeidsintensief om dagelijks uit te voeren. Een eenvoudige bedside test die rechtstreeks op volbloed kan worden toegepast is de Endotoxine SIMPLY RED ${ }^{\circledR}$ (SRE) test, een potentieel klinisch waardevolle test in patiënten met sepsis. In de huidige studie vergelijken wij de chromogene LAL en SRE test en bepalen we de voorspellende waarde in patiënten met een klinisch beeld van sepsis.

Vierenzeventig patiënten werden geincludeerd; waarvan 61 bewezen sepsis hadden. 6 patiënten stierven als gevolg van sepsis, en in 13 patiënten kon sepsis niet worden bevestigd door een positieve bacteriële kweek. Van de 55 overlevenden, waren er 5 positief in de LAL, 12 in de SRE en 2 in beide testen.

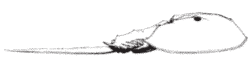


Zowel de positieve als negatieve voorspellende waarden voor beide analyses, in alle septische patiënten, waren laag. Ook wanneer de APACHE II score van de patiënten werd meegenomen in overweging bleven de positieve en negatieve voorspellende waarden te laag voor klinisch gebruik van een van beide tests. De voorspellende waarden van de bloed- en de lokale kweken waren gelijk aan de resultaten van de beide endotoxine analyses. In deze studie kon voor zowel de SRE als de LAL test niet worden aangetoond dat deze te gebruiken is als voorspeller van mortaliteit in patiënten met klinisch bewezen sepsis.

Hoofdstuk VI: Endotoxine, cytokinen en procalcitonine in koortsachtige patiënten opgenomen in het ziekenhuis: identificatie van patiënten met een hoog mortaliteitsrisico.

Wij onderzochten in 464 koortsachtige patiënten (gemiddelde leeftijd 61 jaar) de voorspellers van mortaliteit.

Naast anamnestische factoren (leeftijd, onderliggende ziekte, duur van koorts, rillingen, en shock bij opname) werden TNF-alpha waarden, plasma endotoxine, IL-6, IL-10, en procalcitonine concentraties in bloed gemeten. De mortaliteit was hoger in patiënten die in shock waren bij opname ( $n=31 ; 7$ overleden) vergeleken bij patiënten die dat niet waren bij opname $(n=433 ; 26$ overleden). De endotoxine concentratie was de beste voorspeller van het mortaliteitsrisico, deze voorspelde 5 van de 7 overleden patiënten. Voor patiënten die niet in shock waren bij opname, was de mortaliteit geassocieerd met hogere leeftijd en onderliggende ziekte: de klinische gegevens verzameld bij de anamnese voorspelden $30 \%$ van de sterfgevallen, terwijl IL-6 en procalcitonine concentraties een additionele $10 \%$ identificeerden.

Wanneer patiënten met koorts in het ziekenhuis worden opgenomen, is het klinische oordeel (leeftijd, onderliggende ziekte, en recente medische geschiedenis) een betere voorspeller voor mortaliteit dan de waarden bij opname van endotoxine, cytokine, en procalcitonine. Bij patiënten die zich presenteren in shock is de endotoxine-waarde ook een voorspeller voor een slechte prognose.

Hoofdstuk VII: Micropartikels van patiënten met meervoudig orgaan falen en sepsis bevorderen de stolling via meerdere wegen

Wij onderzochten het aantal en de cellulaire oorsprong van micropartikels (MP) in patiënten met meervoudig orgaan falen (MOF) en sepsis. 9 Patiënten en 14 gezonde controles werden onderzocht op de aanwezigheid van MP in bloedmonsters. Het aantal en de cellulaire oorsprong van de MPs werden bepaald met behulp van flowcytometrie. De stollingsstatus werd bepaald door plasma protrombine fragment F1+2- en trombine-antitrombine complex (TAT) metingen.

De meeste Annexine V positieve MPs waren afkomstig van plaatjes (PMP) en in mindere mate van erytrocyten, endotheel cellen (EMP) en granulocyten (GMP). 
Vergeleken met gezonde controles, waren de aantallen PMP die Annexin V en tissue factor positief waren verlaagd, EMP waren gelijk of verlaagd, EMP waren gelijk en GMP waren verhoogd. GMP aantallen correleerden met plasmaconcentraties van elastase, maar niet met CRP of IL-6 concentraties.

MP afkomstig van de patiënten bevorderden de trombine vorming, die vergeleken met de gezonde controles sterk rembaar was door toevoeging van anti-factor XII monoklonaal $(n=2)$, anti-factor XI monoklonaal $(n=8)$, of anti-TF monoklonaal $(n=4)$. De concentraties F1+2 en TAT waren verhoogd en correleerden omgekeerd evenredig met het aantal circulerende MP en hun trombone-vormende capaciteit.

Hoofdstuk VIII: Verlaagd aantal micropartikels in ernstige knokkelkoorts infectie: mogelijke rol in pathogenese?

Knokkelkoorts (dengue hemorrhagic fever) infectie wordt in de ernstige fase van de ziekte ondermeer gekenmerkt door bloedingen, hetgeen wordt toegeschreven aan thrombocytopenie en thrombocytopathie. Recente studies suggereren dat de abnormale bloedstolling en fibrinolyse een rol spelen in de bloedingsneiging in dit ziektebeeld. Omdat er aanwijzingen zijn voor een rol van de MP in de stolling, bestudeerden wij de aanwezigheid van MP en hun cellulaire oorsprong in patiënten met een ernstige knokkelkoortsinfectie.

Kinderen met verdenking van knokkelkoorts in de leeftijd van 2 tot 14 jaar, die werden opgenomen in de intensive care van het kinderziekenhuis Dr. Kariadi Hospital in Semarang, Indonesia, werden in deze studie opgenomen. Gezonden schoolgaande kinderen in de leeftijd categorie 6 tot 13 jaar, en uit hetzelfde gebied als de zieken kinderen waren de controle groep.

De diagnose knokkelkoorts werd via een serologische antigeen test en RNA immuun blot test bevestigd. Van acht willekeurige patientjes met een bewezen knokkelkoorts infectie werd van de tijdserie, dag 0 (opname), dag 1,2,7 en 30 o.a. MP bepaald.

Het aantal thrombocyten was lager op dag 1 en 2 dan op de dag van opname en op dag 7 was het aantal genormaliseerd. Het aantal MP was bij opname en de eerste 2 dagen verlaagd en bereikten normale aantallen op dag 30 in vergelijking met de controles. Deze studie toonde een verlaagd aantal MP (m.n. MP afkomstig van plaatjes) gedurende ernstige infectie aan.

Hoofdstuk IX: Pravastatine vermindert glycoproteïne IIIa, de fibrinogeen receptor op micropartikels afkomstig van bloedplaatjes in patiënten met type 2 diabetes.

Een belangrijk klinisch probleem in patiënten met diabetes is het risico van cardiovasculaire complicaties. De verschillende studies tonen aan dat statines (HMG-CoA reductase remmers)

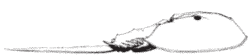


het risico op cardiovasculaire complicaties in patiënten met diabetes kunnen verminderen. Dit beschermende effect wordt hoofdzakelijk toegeschreven aan het cholesterol verlagend vermogen, hoewel andere, zogenaamd pleiotrope effecten van statines ook worden gepostuleerd. De doelstelling in deze studie was om het effect van pravastatine, in patiënten met diabetes (type 2), op het aantal, cellulaire oorsprong en antigene samenstelling van MP te bestuderen.

Patiënten $(n=48)$ met type diabetes 2 werden in een cross-over studie, 8 weken behandeld met pravastatine en 8 weken zonder.

Met behulp van flowcytometrie werd het totaal aantal, de cellulaire oorsprong en de antigeen samenstelling van de MP bepaald.

Wij vonden dat het aantal, de cellulaire oorsprong en de tissue factor expressie op de MP niet door pravastatine werden beïnvloed. Wel was er een verlaging van Glycoproteïne IIIa (CD61) op MP afkomstig van bloedplaatjes tijdens de behandeling met pravastatine. De verminderde fibrinogeen receptor zou theoretisch een bijdrage kunnen leveren aan het gunstige effect van statine-behandeling bij patiënten met diabetes, maar meer onderzoek is ook hier aangewezen. 

Dankwoord 
$+\infty$ 
Dit proefschrift heeft vele dieptepunten en hoogtepunten gekend. Het is een periode geweest waar in ik veel geleerd maar ook afgeleerd heb, compromissen leren maken en mijn idealen heb leren bijstellen. Ik heb met zeer veel mensen samengewerkt waarvan ik verre weg de meeste een warm hart toedraag. Helaas kan ik niet ontkennen dat er toch ook enkele teleurstellingen waren. Niet te min is het proefschrift een rugzak geweest die ik lange tijd heb gedragen. Ik ben dan ook trots en dankbaar dat de promotie een feit geworden is, hoewel het zonder die rugzak vreemd zal voelen.

Hoewel het proefschrift mijn naam draagt, hebben er velen aan bijgedragen. Guus Sturk wil ik bedanken, omdat hij degene geweest is die de eerste kans heeft geboden om zelfstandig onderzoek te doen in het LUMC te Leiden. Helaas heb ik mijn proefschrift niet bij jouw groep afgemaakt, omdat wij zo verschillend in het leven staan. Rienk Nieuwland wil ik bedanken voor zijn bijdrage bij het schrijven van hoofdstuk VIII.

Aan de afdeling infectie-ziekten ben ik veel dank verschuldigd, met name professor van Dissel, voor het leveren van plasmamonsters en klinische gegevens van koortsige patiënten (hoofdstuk VI). Twee andere medewerkers van deze afdeling waren mijn steun en toeverlaat. Lieve Paul en Hanneke jullie hebben mij de kliniek leren verkennen en mij ook laten inzien dat het recruiteren van patiënten voor ons onderzoek een tijdrovende zaak is. Ik heb zeer veel van jullie geleerd.

De hele groep medewerkers van de klinische chemisch laboratorium in het LUMC heb ik als zeer sympathieke en hulpvaardige groep ervaren en wil deze daarvoor bedanken. Toch wil ik een paar mensen met wie ik nauw samen hebt gewerkt er uitlichten; Margo en Marja voor het overnemen en verder opzetten van de volbloed stimulatie. Marry en Margreth voor het overnemen van de endotoxine bepaling. Als er een reeks creatinine kinase bepalingen moest worden gedaan was dat geen moeite om het te regelen met 'Wimmie' en als ze dan gedaan werden stond Henny in zijn avonddienst klaar om alles te bepalen. Buiten de inhoudelijke bijdrage zijn sociale oppeppraatjes zeker zeer belangrijk. Lieve Conny tegen jouw kon ik altijd aanzeuren als dingen niet zo lekker gingen. Op jouw luisterend oor kon ik altijd rekenen, we hebben samen ook heel wat afgelachen. Philiph ook jij had altijd een luisterend oor wanneer het niet zo lekker ging. Bij Eef kon ik altijd terecht voor goede raad. Als echte gebruiker van de computer stuit je op allerlei problemen en dan was mijn noodkreet: 'Urban!' Jij was altijd weer bereid om mij uit de computerproblemen te helpen.

De mensen van het research lab LUMC wil ik bedanken voor hun bijdragen; Lieve Fred, jij met je altijd goeie humeur hebt me geholpen met het analyseren van de MOF monsters. Ook Anita, Ria, Marianne en René bedank ik voor hun ondersteuning en hulp.

Een van die hoogtepunten was absoluut de triatlon-studie in samenwerking met de universiteit van Maastricht samen met Ton Wagenmakers, Asker Jeukendrup, Joan Senden en Jos Stegen. 
Het lab was in een tent in Embrun. Het meemaken van onderzoek doen op locatie was een ervaring om nooit te vergeten.

Toen ik in het OLVG ging werken heb ik mijn rugzakje weer mee genomen en zijn de laatste twee hoofdstukken ontstaan. Samen met Anja Leyte was het opzetten van research op de een diagnostisch lab een ware uitdaging. Anja, jij was degene die mij weer aangemoedigd heb om het proefschrift af te ronden. Jij heb me kennis laten maken met Ronne en Dirkje. Het samen werken met jou, Ronne, was zeer inspirerend, ik heb je leren kennen als een echte wetenschapper: gedreven en enthousiast. Jouw Dengue-studie gaf weer een nieuwe dimensie aan de betekenis van MPs. We hebben heel wat gepuzzeld om een overzicht te krijgen in alle gegevens. Wat uiteindelijk toch geresulteerd heeft in een mooi artikel. De diabetes-studie samen met Dirkje was een verrassende studie. Jij, Dirkje, hoogzwanger in die tijd, was super om samen mee te werken.

De mensen van het OLVG lab waren een geweldige groep mensen, een aantal wil ik met name bedanken. Dik(el), jij hebt heel wat getallen een tweede controle-ronde gegeven. Verder de samenwerking met Frans, Cieleke, Martijn en Wendy waren meer voor mij dan gewoon collega's zijn. Daarom ook lieve Wendy was jij bereid om naast mij te staan tijdens de promotie, wat ik enorm waardeer.

Lieve Hugo, jouw steun en wijze woorden zijn onmisbaar geweest. Als ik met andere over jouw praat zeg ik altijd het is zo'n 'schatje'. Jij bent degene die me iedere keer stimuleerde om verder te gaan. Zonder jouw zou dit boekje er niet zijn geweest. We kennen elkaar al vanaf 1981 en hebben zo ieder onze eigen weg bewandeld. Jij bent hoogleraar geworden in Maastricht, en hebt Amsterdam achter je gelaten. Onze wegen kruisten elkaar weer toen ik werkzaam was in het OLVG. De oude gekke verhalen uit de WG tijd kwamen weer boven. Dat jij mijn promotor wou zijn en in mij geloofde is een enorme eer.

De overstap naar de farmaceutische industrie was voor mij zeker een 'eye opener'. Lieve Sarianne, jij als Pietje Precies hebt heel wat van mijn slordigheden zoals verschillen in lettertypes in het zelfde document gecorrigeerd. Ik die gewend was snel SOPs te lezen en daarom onderaan begon was voor jouw onbegrijpelijk! Ook tijdens het schrijven van de bedelbrieven en andere stukjes was het jouw kritische blik die alle foutjes eruit haalden. Ik heb heel veel geleerd, misschien ben ik nu ook zo'n Pietje Precies?

Naast alle mensen in de werkomgeving zijn er ook mensen in de privé-sfeer, de zogenoemde 'sponsors' (zie stelling). Lieve Edith, ik wil je bedanken voor al die oppas-uurtjes. Ik kon je altijd bellen als er onverwachts een bespreking was. Ook Carla jouw wil ik bedanken voor de tijd die je op Maikel hebt gepast. 
Lieve Pa en Ma geen woorden zijn de juiste om mijn gevoel te beschrijven, maar jullie weten het wel............

Wat mijn mannen betreft, jullie steun is natuurlijk onmisbaar geweest. Dit heb ik in 'Ode aan de Mannen' geprobeerd onder woorden te brengen. Maar in hoeverre kan dat? Jullie hebben deze rugzak samen met mij gedragen.

Ik zal ongetwijfeld mensen zijn vergeten maar het zal duidelijk zijn dat deze rugzak door vele is gevuld. En ieder die mij kent weet wel dat ik ze een warm hard toedraag ook al ben ik je naam vergeten.

Zonder jullie 


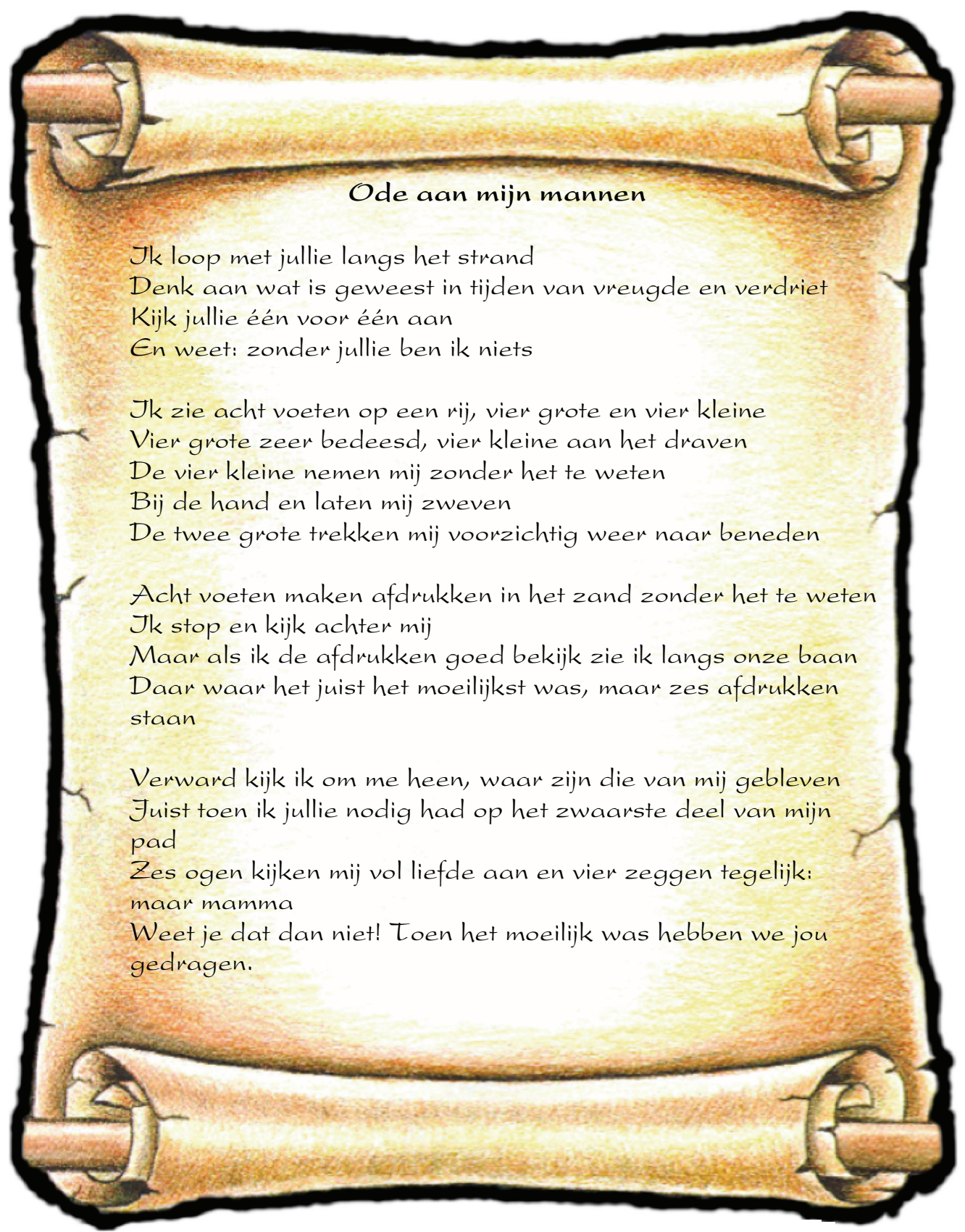

Gebaseerd op het engelse gedicht uit 1936 'Foorprints in the sand' van Mary Stevenson (1922-1999) 
Curriculum Vitae 

Karin Joop werd geboren op 26 maart 1962 te Zaandam. In 1978 deed zij MAVO-4 eind examen en in datzelfde jaar werd aangevangen met de dag opleiding MBO KlinischChemie te Amsterdam. In 1981 werd het diploma behaald en is zij begonnen in het Wilhelmina Gasthuis op de afdeling hematologie als analiste. Na de verhuizing in 1983 van het Wilhelmina gasthuis naar het Academisch Medisch Centrum (AMC) behaalde zij in 1984 in de avonduren het HBO-A diploma klinische chemie en was reeds werkzaam op gelijknamige afdeling. In 1988 werd eveneens in de avonduren het HBO-B MedischeBiologie gehaald en in 1989 werd zij hoofd-analiste op het fertiliteitslaboratorium in het AMC. In het kader van het fertiliteitsonderzoek schreef zij in het vakblad voor analisten en won daarmee in 1991 de Anna Wichers prijs. Na anderhalf jaar ging zij weer onderzoek doen op de afdeling hematologie waar zij in 1993 het HLO diploma klinische chemie avond-opleiding behaalde. Ook doceerde zij van 1989 tot 1992 aan de Hogeschool van Amsterdam. In 1994 is zij met de hoogleraar en een groep mensen uit het AMC naar het Leids Universitair Medisch Centrum (LUMC) gegaan om daar onderzoek te doen naar infecties en coagulatie. Tussen 2001 tot eind 2005 is zij werkzaam geweest in het Onze Lieve Vrouwe Gasthuis, waar zij de beenmerg diagnostiek heeft helpen opzetten. In 2006 heeft zij beenmerg morfologie verricht, op de afdeling celdiagnostiek. in het Utrecht Medisch Centrum. In 2007 heeft zij de overstap gemaakt naar de farmaceutische industrie. $\mathrm{Na} 1$ jaar via Quintiles bij Centocor, Leiden te hebeen gewerkt als Clinical Trial Assistent. Is zij via Covance nu werkzaam bij Merck Sharp \& Dohme BV. te Haarlem als Clinical Research Associate. 

Publications 
Sommeijer D.W., Joop K., Leyte A., Reitsma P.H., ten Cate H. Pravastatin reduces fibrinogen receptor gpIIIa on platelet-derived microparticles in patients with type 2 diabetes. J Thromb Haemost 2005; 3(6):1168-71.

Joop K., Berckmans R.J., Nieuwland R., Berkhout J., Romijn F.P., Hack C.E., Sturk A. Microparticles from patients with multiple organ dysfunction syndrome and sepsis support coagulation through multiple mechanisms. Thromb Haemost 2001; 85(5):810-20.

Jeukendrup A.E., Vet-Joop K., Sturk A., Stegen J.H., Senden J., Saris W.H., Wagenmakers A.J. Relationship between gastro-intestinal complaints and endotoxemia, cytokine release and the acute-phase reaction during and after a long-distance triathlon in highly trained men. Clin Sci (Lond) 2000; 98(1):47-55.

Dohmen M.J., Joop K., Sturk A., Bols P.E., Lohuis J.A. Relationship between intra-uterine bacterial contamination, endotoxin levels and the development of endometritis in postpartum cows with dystocia or retained placenta. Theriogenology 2000; 54(7):1019-32.

Joop K., van Langevelde P., van Loon J., Frolich M., Groeneveld P.H., Westendorp R.G., van Dissel J.T. Endotoxin, cytokines, and procalcitonin in febrile patients admitted to the hospital: identification of subjects at high risk of mortality. Clin Infect Dis 2000; 31(6): $1343-8$.

Osmanovic N., Romijn F.P., Joop K., Sturk A., Nieuwland R. Soluble selectins in sepsis: microparticle-associated, but only to a minor degree. Thromb Haemost 2000; 84(4):731-2.

Joop K. Een fertiliteits-laboratorium: wat houdt dat eigelijk in? Tijdschrift voor medische analisten 1991; 2 (46):26-32

Sturk A., Janssen M.E., Muylaert F.R., Joop K., Thomas L.L., ten Cate J.W. Endotoxin testing in blood. Prog Clin Biol Res 1987; 231:371-85.

Sturk A., Joop K., ten Cate J.W., Thomas L.L. Optimalization of a chromogenic assay for endotoxin in blood. Prog Clin Biol Res 1985; 189:117-37.

Thomas L.L., ten Cate H., Sturk A., Joop K., ten Cate J.W. Quantitative chromogenic endotoxin determination in cerebrospinal fluid. Clin Chim Acta 1983; 127(1):137-9.

Thomas L.L., Henny C.P., Buller H.R., Sturk A., Joop K., ten Cate J.W. Chromogenic endotoxin determination in blood-clinical relevance. Klin Wochenschr 1982; 60(14):759-60. 